\title{
PHYSICAL, CHEMICAL, AND BIOLOGICAL CHARACTERISTICS OF THREE RESERVOIRS IN WEST-CENTRAL MISSOURI, 1991-93
}

\section{By DAVID C. HEIMANN}

U.S. GEOLOGICAL SURVEY

Water-Resources Investigations Report 95-4120

Prepared in cooperation with the JACKSON COUNTY PARKS AND RECREATION DEPARTMENT and the CASS COUNTY SOIL AND WATER CONSERVATION DISTRICT 


\section{U.S. DEPARTMENT OF THE INTERIOR BRUCE BABBITT, Secretary}

U.S. GEOLOGICAL SURVEY

Gordon P. Eaton, Director

For additional information write to:

District Chief

U.S. Geological Survey

1400 Independence Road

Mail Stop 200

Rolla, Missouri 65401
Copies of this report may be purchased from:

U.S. Geological Survey Earth Science Information Center Open-File Reports Section Box 25286, Mail Stop 517 Denver Federal Center Denver, Colorado 80225 


\section{CONTENTS}

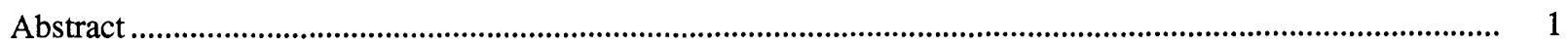

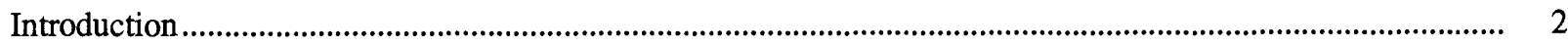

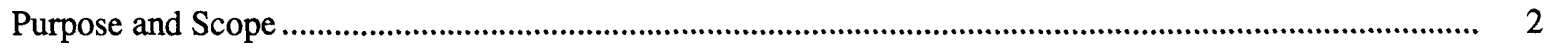

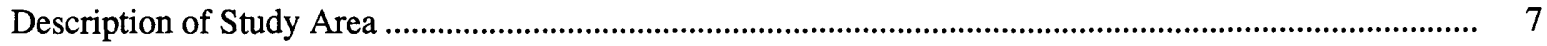

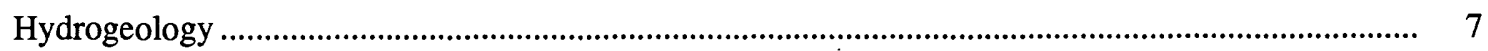

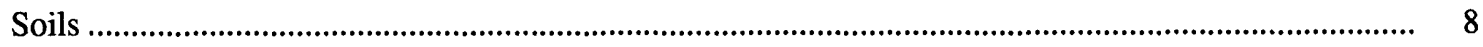

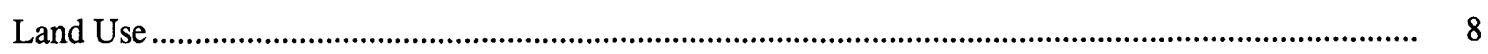

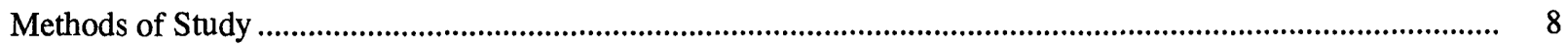

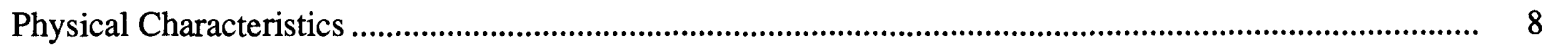

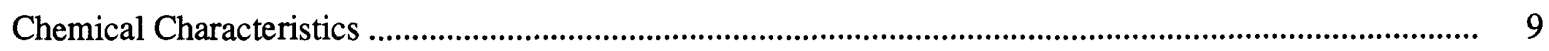

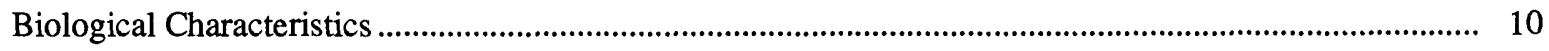

Reservoir Inflow and Outflow and Precipitation ....................................................................... 10

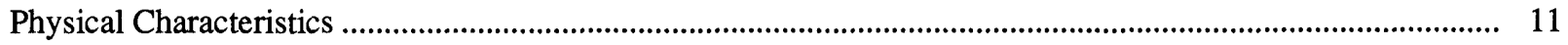

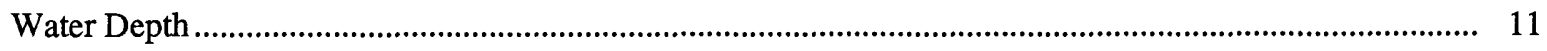

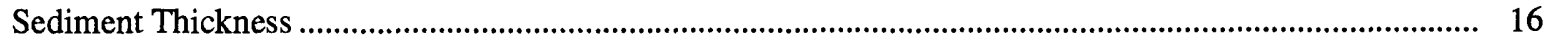

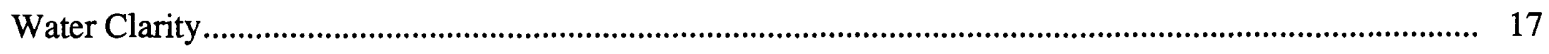

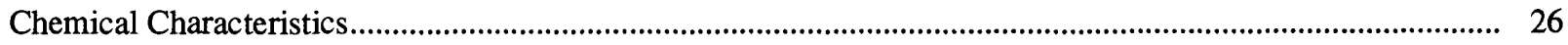

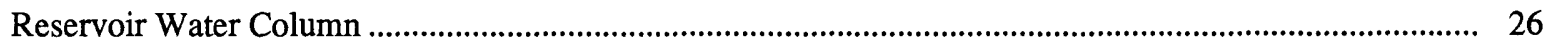

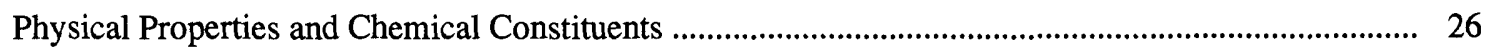

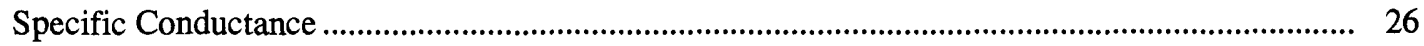

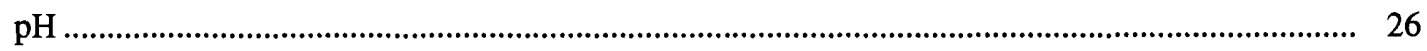

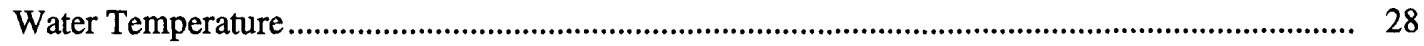

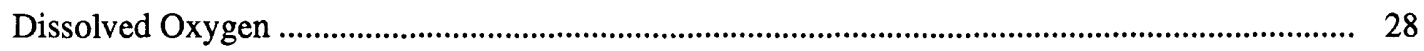

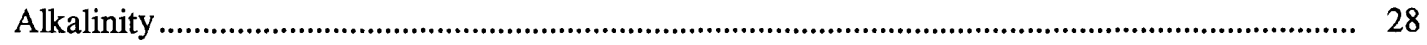

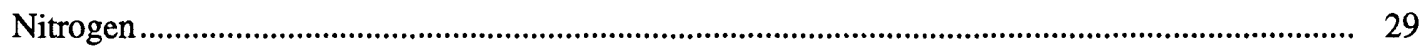

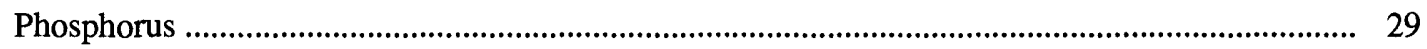

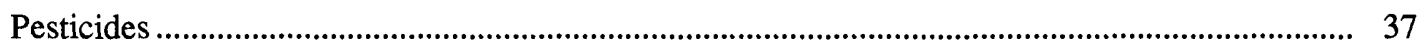

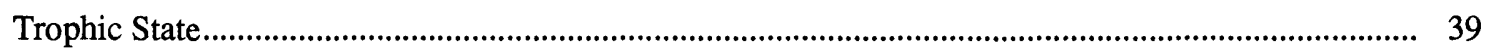

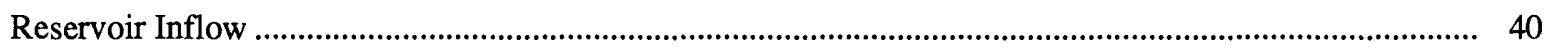

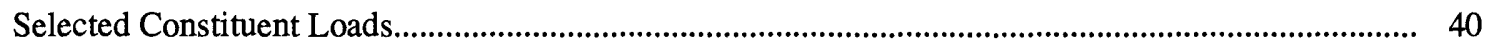

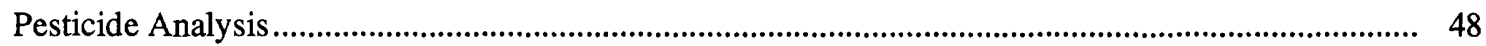

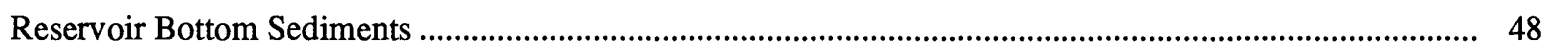

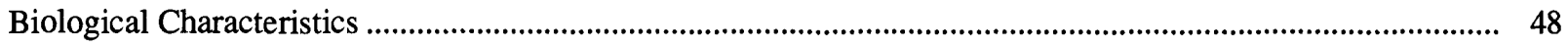

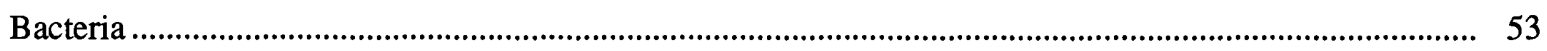

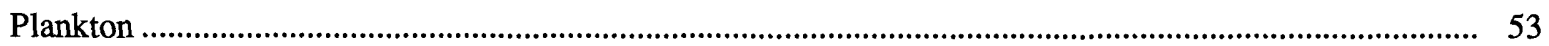

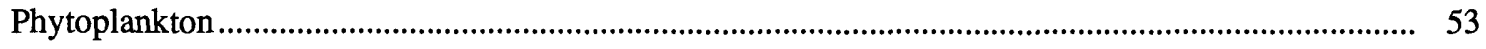

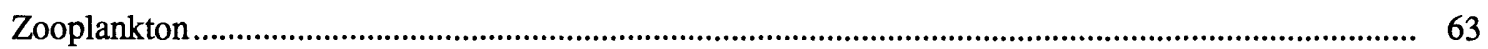

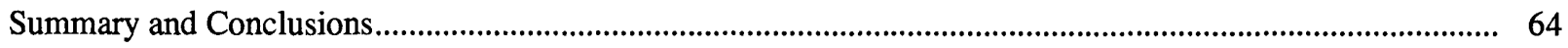

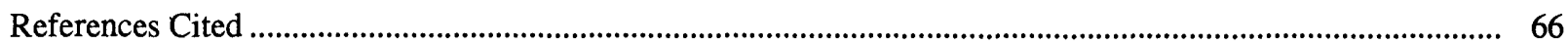




\section{FIGURES}

1-3. Maps showing:

1. Location of three reservoirs in west-central Missouri and natural divisions of Missouri

2. Location of sampling sites in Prairie Lee Lake and Lake Jacomo Basins, west-central Missouri

3. Location of sampling sites in Harrisonville City Lake Basin, west-central Missouri..................... 5

4. Bathymetric maps of three reservoirs in west-central Missouri

5. Graphs showing depth-area and depth-capacity curves of three reservoirs in west-central Missouri.

6. Sediment-thickness maps of three reservoirs in west-central Missouri

7-19. Graphs showing:

7. Secchi disk depth and total suspended solids, suspended sediment, chlorophyll $a$, and suspended sediment concentrations in water samples from three reservoirs in westcentral Missouri

8. Specific conductance and $\mathrm{pH}$ values in water samples from three reservoirs in west-central Missouri

9. Depth-time distribution of water temperature and dissolved oxygen in three reservoirs in west-central Missouri

10. Alkalinity in water samples from three reservoirs in west-central Missouri

11. Total organic nitrogen, total ammonia, and total nitrate concentrations in water samples from three reservoirs in west-central Missouri

12. Total phosphorus and total orthophosphate concentrations in water samples from three reservoirs in west-central Missouri

13. Temporal distribution of atrazine and atrazine metabolites and reservoir stage, Harrisonville City Lake, west-central Missouri, site HL2

14. Mean surface Trophic-State Index values for three reservoirs in west-central Missouri

15. Storm loads for selected constituents at inflow sites, Prairie Lee Lake, west-central Missouri

16. Storm loads for selected constituents at the inflow site, Lake Jacomo, west-central Missouri.....

17. Storm loads for selected constituents at inflow sites, Harrisonville City Lake, west-central Missouri

18. Phytoplankton density and composition by taxonomic division from surface samples from three reservoirs in west-central Missouri

19. Zooplankton density by taxa, Harrisonville City Lake, west-central Missouri, site HL2. 


\section{TABLES}

1. Sampling site information for three reservoirs in west-central Missouri .................................................. 6

2. Basin characteristics for inflow and outflow sampling sites for three reservoirs in west-central

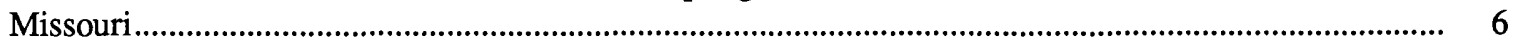

3. Morphometric characteristics of three reservoirs in west-central Missouri ................................................ 7

4. Precipitation data for James A. Reed Memorial Wildlife Area in Lee's Summit, Missouri, May 1991-April 1992, and Harrisonville City Lake, near Harrisonville, Missouri, April 1992-July 1993

5. Associated continuous-record gaging station data used in calculating mean annual runoff for

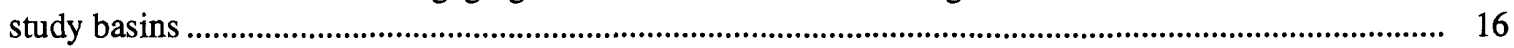

6. Hydraulic residence times for three reservoirs in west-central Missouri .............................................. 16

7. Sediment dredging record, Prairie Lee Lake and Lake Jacomo, west-central Missouri, 1973-80 ............ 17

8. Summary statistics of water-clarity characteristics in surface and bottom samples from three

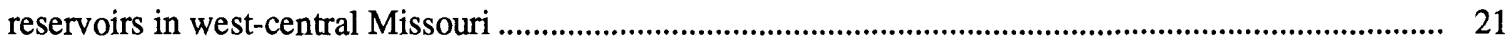

9. Summary statistics of selected physical properties and chemical constituents from three

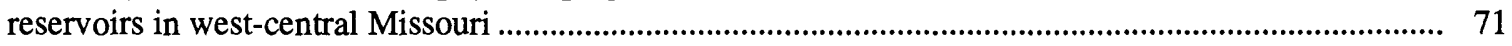

10. Pesticide concentrations in water samples from Harrisonville City Lake, west-central Missouri............. 77

11. Trophic state classification criteria for Missouri lakes and reservoirs based on chlorophyll $a$, total nitrogen, and total phosphorus concentrations

12. Constituent concentrations used in trophic state classification of three reservoirs in west-central Missouri

13. Pesticide concentrations in water samples from Harrisonville City Lake inflow sites, west-central Missouri.

14. Selected constituent concentrations in bottom sediment samples from three reservoirs in west-central Missouri

15. Pesticide concentrations in bottom sediment samples from three reservoirs in west-central Missouri.

16. Bacteria densities in water samples from Prairie Lee Lake, west-central Missouri ................................ 54

17. Bacteria densities in water samples from Lake Jacomo, west-central Missouri ....................................... 56

18. Bacteria densities in water samples from Harrisonville City Lake, west-central Missouri ....................... 58

19. Bacteria densities in stormwater-runoff samples in Prairie Lee Lake inflow sites, west-central Missouri.

20. Bacteria densities in stormwater-runoff samples from Lake Jacomo inflow site PL4, west-central Missouri

21. Bacteria densities in stormwater-runoff samples from Harrisonville City Lake inflow sites, west-central Missouri

22. Phytoplankton densities and biovolumes in three reservoirs in west-central Missouri ............................ 90

23. Zooplankton densities in Harrisonville City Lake, west-central Missouri. 


\section{Physical, Chemical, and Biological Characteristics of Three Reservoirs in West-Central Missouri, 1991-93}

\author{
By David C. Heimann
}

\section{Abstract}

A comprehensive investigation of Prairie Lee Lake and Lake Jacomo was conducted from May 1991 through April 1992 to quantify physical, chemical, and biological characteristics of these recreational reservoirs in Jackson County, Missouri. A similar investigation was conducted from April 1992 through June 1993 at Harrisonville City Lake, a recreational and drinking-water supply reservoir in Cass County. The investigation of each reservoir included a bathymetric and sedimentation survey; chemical analyses of water and bottom sediments; and quantitative analyses of bacteria, and phytoplankton.

Water samples from Harrisonville City Lake (water samples were analyzed for pesticides only at this reservoir) were analyzed for 20 pesticides, and the concentration of 9 of 20 pesticides exceeded detection limits. The pesticides detected included atrazine, desethylatrazine, deisopropylatrazine, metolachlor, ametryn, propazine, alachlor, 2,4-D, and cyanazine. Atrazine concentrations were greater than the health-based maximum contaminant level of 3 micrograms per liter in all surface and bottom water samples collected between April and November 1992. The mean concentration of atrazine in 36 surface samples was 2.8 micrograms per liter, and the mean concentration of atrazine in 11 bottom samples was 3.3 micrograms per liter. None of the remaining eight pesticides that were detected exceeded health-based limits.

Results of sediment-depth surveys of the reservoirs indicated that the reservoirs have lost a considerable amount of their original volume. Approximately 1,180 acre-feet of sediment have accumulated in Prairie Lee Lake since the dam was built during 1939 , resulting in a 29 percent loss in the original reservoir volume. In Lake Jacomo approximately 1,910 acre-feet of sediment have been deposited since 1959, resulting in an 8 percent loss in original volume. An estimated 1,130 acre-feet of sediment have accumulated in Harrisonville City Lake since 1972, resulting in a 14 percent loss in volume.

The mass and mass per acre loads of total suspended solids, ammonia, nitrate, and total phosphorus in stormwater-runoff samples from Prairie Lee Lake outflows were about one-third the mass and mass per acre loads of Prairie Lee Lake inflows, indicating that Prairie Lee Lake is a sediment and nutrient "trap." The estimated mass per acre loads of ammonia and nitrate from direct precipitation on Prairie Lee Lake, Lake Jacomo, and Harrisonville City Lake exceeded loads from tributary inflows for most sampled storms.

The differences in median values of waterclarity characteristics of the reservoirs, including Secchi depth, suspended solids, suspended sediment, and chlorophyll $a$, were compared between sites within an individual reservoir to determine if these differences were statistically significant. The only significant difference detected was in Secchi depth values between three Lake Jacomo sites (Kruskal-Wallis test, alpha $=0.05$ ). It seems that Secchi depths were significantly lower at one site because of effects from the outflows of Prairie Lee Lake.

The spring and summer phytoplankton population in Prairie Lee Lake samples was dominated by cyanophytes. By late summer the chlorophytes became dominant in Prairie Lee 
Lake and chrysophytes in Lake Jacomo samples. The phytoplankton population in Harrisonville City Lake was dominated by chrysophytes during much of the spring and summer of 1992. Cyanophytes comprised the largest part of the phytoplankton population in the late August samples. Chlorophytes were the dominant taxa in the October samples.

The temporal distribution of the total nitrogen to total phosphorus ratios calculated from surface samples in the reservoirs indicates that phosphorus is the nutrient that limits phytoplankton production throughout the spring and summer months. The data are less conclusive during the fall and winter months in Lake Jacomo and Harrisonville City Lake, and additional analyses would be needed to determine the nutrient that limits production during these months.

The trophic condition of the reservoirs was determined using Carlson's Trophic-State Index. There were inconsistences in results over time and between index values, but all three reservoirs were classified as mesotrophic to eutrophic. The trophic condition of the three reservoirs also was determined using classification criteria generated for Missouri reservoirs utilizing chlorophyll $a$, total nitrogen, and total phosphorus concentrations. Based on these criteria, Prairie Lee Lake was classified as eutrophic, and Lake Jacomo and Harrisonville City Lake were classified as mesotrophic to eutrophic.

\section{INTRODUCTION}

Prairie Lee Lake (figs. 1 and 2) is a recreational reservoir located in a basin affected by rapid urbanization. The quality of water in this reservoir is threatened by high bacteria counts, sedimentation, eutrophication, and pesticide contamination in bottom sediments. Historical (Buckner, 1976) and recent studies (Jackson County Parks and Recreation Department, written commun., 1990, 1991) indicated that fecal coliform densities in samples collected from Prairie Lee Lake and its tributaries have exceeded State standards [more than $200 \mathrm{col} / 100 \mathrm{~mL}$ (colonies per 100 milliliters)] for whole-body contact recreation (Missouri Department of Natural Resources, 1992). Prairie Lee Lake has been classified as highly eutrophic (Jones and Knowlton, 1993), and nutrient input from non-point sources has caused algal blooms associated with odor and aesthetic degradation. Chlordane concentrations in fish tissue samples from Prairie Lee Lake have exceeded the U.S. Food and Drug Administration's health-based "action level" of 300 $\mu \mathrm{g} / \mathrm{g}$ (micrograms per gram; Alan Buchanan, Missouri Department of Conservation, written commun., 1991). The outflow from Prairie Lee Lake is uncontrolled and flows directly into Jackson County Lake, hereafter referred to as Lake Jacomo (fig. 2). Symptoms of eutrophication, including increased sedimentation, and fecal coliform contamination also occur in Lake Jacomo. A monitoring investigation was conducted from May 1991 through April 1992 by the U.S. Geological Survey in cooperation with Jackson County Parks and Recreation Department. The objectives of this investigation were to quantify physical, chemical, and biological characteristics of the two reservoirs (Prairie Lee Lake and Lake Jacomo) and to determine the extent and sources of contaminants in the reservoirs.

Harrisonville City Lake (fig. 3) is a drinkingwater supply for many Cass County residents. The basin primarily drains agricultural land. The extent to which sediment, nutrients, and pesticides in the runoff are affecting this reservoir is not known. A monitoring investigation was conducted at this reservoir from April 1992 through March 1993 by the U.S. Geological Survey in cooperation with the Cass County Soil and Water Conservation District. The objectives of this investigation were to quantify sedimentation, pesticide loads, and algal production.

\section{Purpose and Scope}

This report presents selected physical, chemical, and biological data and describes the characteristics of three reservoirs-Prairie Lee Lake, Lake Jacomo, and Harrisonville City Lake-in west-central Missouri near Kansas City. A discussion of the physical characteristics of the reservoirs, including reservoir depth and volume, sediment thickness, and water clarity, is followed by a discussion of chemical characteristics, including physical properties (specific conductance, $\mathrm{pH}$, temperature, alkalinity, and dissolved oxygen) and chemical constituents (nutrients and pesticides from one reservoir). The final section describes some of the biological characteristics of the reservoirs, including bacteria densities, phytoplankton 


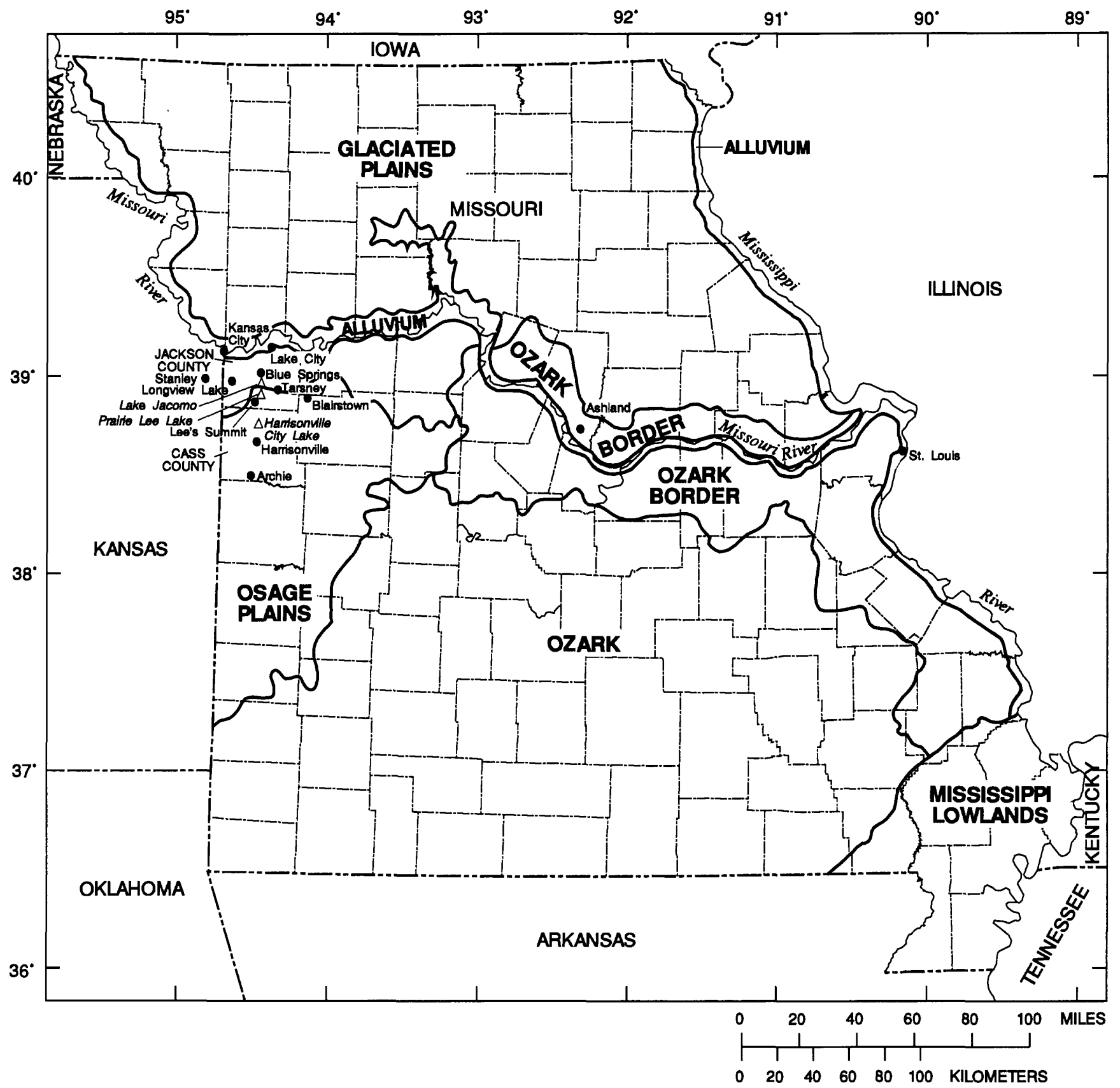

Figure 1. Location of three reservoirs in west-central Missouri and natural divisions of Missouri (modified from Nelson, 1985).

composition and densities, and zooplankton composition (at one reservoir).

Water samples were collected in the Prairie Lee Lake Basin from May 1991 through April 1992 from three reservoir monitoring sites at two depths, one outflow site, and three inflow sites. Water samples were collected in the Lake Jacomo Basin during this same period from three reservoir sites at two depths and one outflow site (fig. 2; tables 1 and 2). Laboratory analyses of water samples included total suspended solids, suspended sediment, and nutrient concentrations.

Three bottom sediment samples were collected from each reservoir and analyzed for trace elements, total nitrogen $(\mathrm{N})$ and phosphorus $(\mathrm{P})$, and pesticides. 


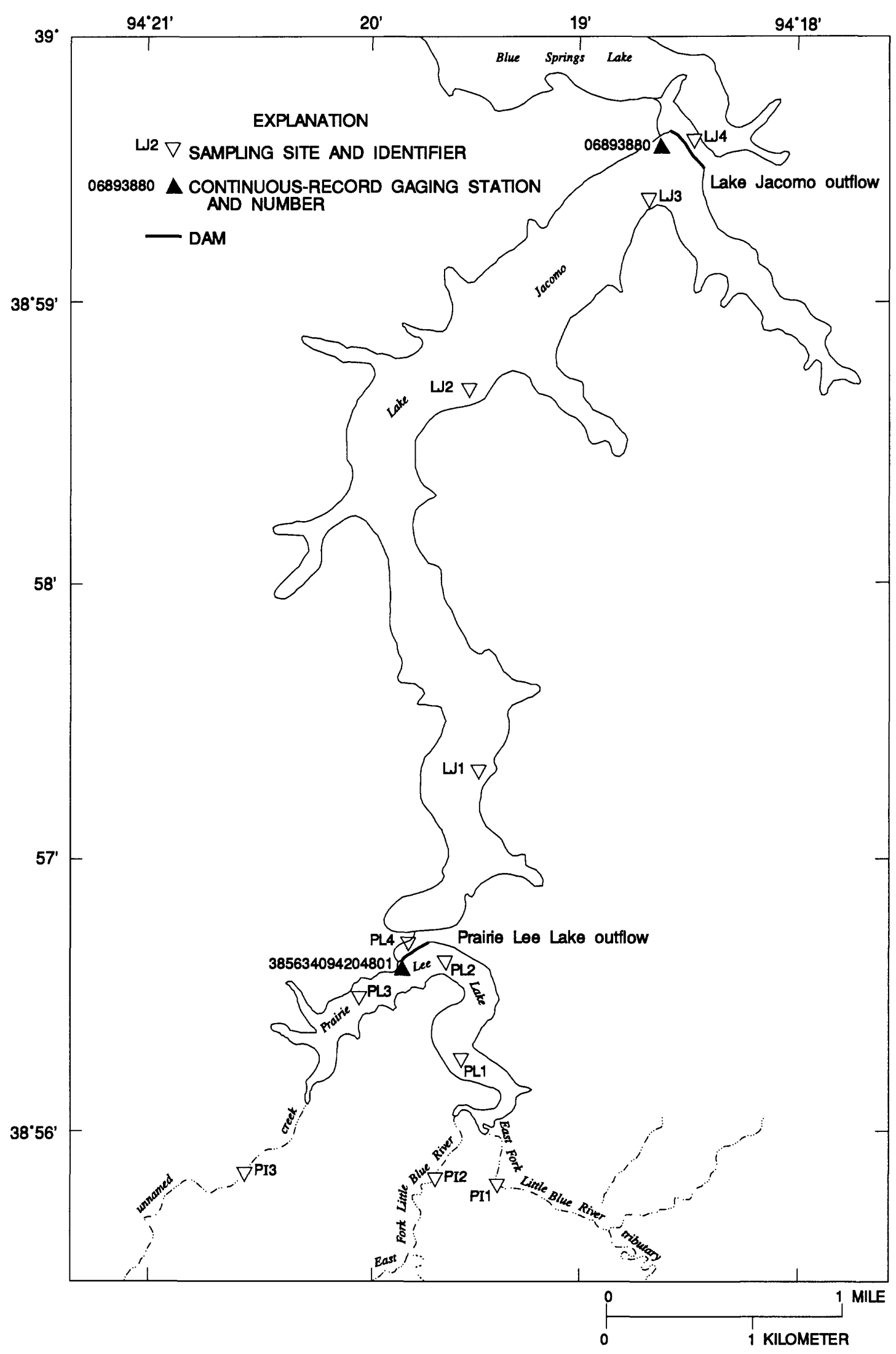

Figure 2. Location of sampling sites in Prairie Lee Lake and Lake Jacomo Basins, west-central Missouri. 


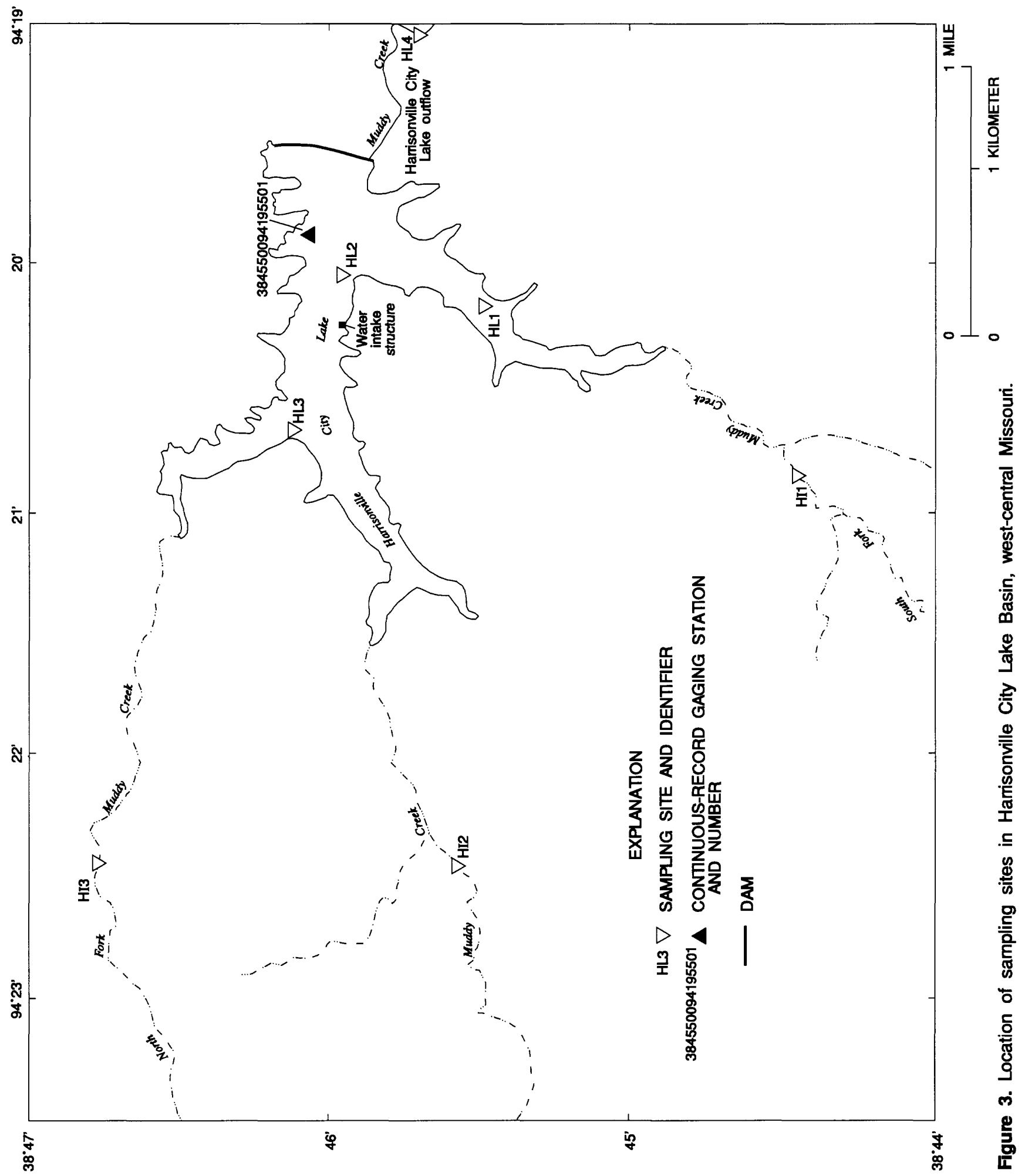


Table 1. Sampling site information for three reservoirs in west-central Missouri [--, not applicable]

\begin{tabular}{cclc}
\hline $\begin{array}{c}\text { Slte Identifier } \\
\text { (flgs. 2 and 3) }\end{array}$ & $\begin{array}{c}\text { U.S. Geologlcal Survey } \\
\text { number }\end{array}$ & \multicolumn{1}{c}{ Name } & $\begin{array}{c}\text { Sample depth } \\
\text { (feet) }\end{array}$ \\
\hline PL1 & 385616094194502 & Prairie Lee Lake & 1.5 \\
& 385616094194501 & Prairie Lee Lake, southeast arm at surface & 20 \\
PL2 & 385636094194402 & Prairie Lee Lake, near dam at surface & 1.5 \\
& 385636094194401 & Prairie Lee Lake, near dam at bottom & 44 \\
PL3 & 385632094200102 & Prairie Lee Lake, southwest arm at surface & 1.5 \\
& 385632094200101 & Prairie Lee Lake, southwest arm at bottom & 36 \\
LJ1 & 385716094193202 & Lake Jacomo, south site at surface & 1.5 \\
& 385716094193201 & Lake Jacomo, south site at bottom & 18 \\
LJ2 & 385841094193802 & Lake Jacomo, central site at surface & 1.5 \\
& 385841094193801 & Lake Jacomo, central site at bottom & 35 \\
LJ3 & 385926094184002 & Lake Jacomo, near dam at surface & 1.5 \\
& 385926094184001 & Lake Jacomo, near dam at bottom & 45 \\
& & Harrisonville City Lake & 1.5 \\
HL1 & 384520094201802 & Harrisonville City Lake, south arm at surface & 22 \\
& 384520094201801 & Harrisonville City Lake, south arm at bottom & 1.5 \\
HL2 & 384559094200102 & Harrisonville City Lake, near dam at surface & 38 \\
& 384559094200101 & Harrisonville City Lake, near dam at bottom & - \\
HL3 & 384559094200103 & Harrisonville City Lake, near dam at metalimnion & 1.5 \\
& 384604094214002 & Harrisonville City Lake, west arm at surface & 22 \\
\hline & 384604094214001 & Harrisonville City Lake, west arm at bottom & \\
& & &
\end{tabular}

Table 2. Basin characteristics for inflow and outflow sampling sites for three reservoirs in west-central Missouri $[-$, not applicable $]$

\begin{tabular}{|c|c|c|c|}
\hline $\begin{array}{l}\text { SIte Identlfler } \\
\text { (figs. } 2 \text { and } 3 \text { ) }\end{array}$ & $\begin{array}{l}\text { U.S. Geologlcal } \\
\text { Survey } \\
\text { number }\end{array}$ & Name & $\begin{array}{c}\text { Dralnage } \\
\text { basin area } \\
\text { (acres) }\end{array}$ \\
\hline \multicolumn{4}{|l|}{ Inflow sites } \\
\hline \multicolumn{4}{|c|}{ Prairie Lee Lake } \\
\hline PI1 & 385515094200501 & East Fork Little Blue River Tributary near Lee's Summit & 2,710 \\
\hline PI2 & 385515094202001 & East Fork Little Blue River near Lee's Summit & 1,830 \\
\hline PI3 & 385548094211601 & Unnamed creek near Lee's Summit & 1,520 \\
\hline \multicolumn{4}{|c|}{ Lake Jacomo } \\
\hline PL4 & 385634094204801 & Prairie Lee Lake spillway & -- \\
\hline \multicolumn{4}{|c|}{ Harrisonville City Lake } \\
\hline HI1 & 384441094204301 & South Fork Muddy Creek near Harrisonville & 915 \\
\hline HI2 & 384525094223301 & Muddy Creek near Harrisonville & 538 \\
\hline HI3 & 384613094223101 & North Fork Muddy Creek near Harrisonville & 1,830 \\
\hline \multicolumn{4}{|l|}{ Outflow sites } \\
\hline \multicolumn{4}{|c|}{ Prairie Lee Lake } \\
\hline PL4 & 385634094204801 & Prairie Lee Lake outflow & -- \\
\hline \multicolumn{4}{|c|}{ Lake Jacomo } \\
\hline LJ4 & 06893880 & Jackson County Lake near Blue Springs (Lake Jacomo) outflow & -- \\
\hline \multicolumn{4}{|c|}{ Harrisonville City Lake } \\
\hline HL4 & 384537094193501 & Harrisonville City Lake downstream from outflow & -- \\
\hline
\end{tabular}


Water samples were collected in the Harrisonville City Lake Basin April 1992 through March 1993 from three reservoir sites at multiple depths, one outflow site, and three inflow sites (fig. 3; tables 1 and 2). Analyses included concentrations of total suspended solids, suspended sediment, nutrients, and pesticides. Nine bottom sediment samples were collected from Harrisonville City Lake between October 1992 and June 1993. Three samples collected in October 1992 were analyzed for total $\mathrm{N}$ and $\mathrm{P}$, trace elements, and pesticides. The remaining six bottom sediment samples were analyzed only for pesticides.

Statistical methods used in the analyses of collected physical, chemical, and biological data included the use of the Mann-Whitney test and the KruskalWallis test (Helsel and Hirsch, 1992) and calculation of the Spearman's rank order correlation coefficient (Ott, 1993). The Mann-Whitney test is used to determine the statistical significance in the difference in the medians of two groups, whereas the Kruskal-Wallis test is used to determine the differences in medians from two or more groups. The Spearman's rank order correlation coefficient is calculated to determine the strength of the relation between two variables regardless of whether the association between the two variables is linear or nonlinear. A significance level of 0.05 was used in all statistical tests in this report.

\section{Description of Study Area}

Prairie Lee Lake and Lake Jacomo (fig. 2) are formed by man-made dams on the East Fork of the Little Blue River and both are used for recreation. Construction of Prairie Lee Lake Dam began during 1936 as a Works Progress Administration project to provide water for the area in time of drought (Kansas City Star, 1944). The dam was completed during 1939 but did not meet Federal government specifications; consequently, low pool levels were maintained while a new dam was constructed. The new dam was completed during 1944, and the current (1994) uncontrolled spillway was completed during 1957. Major inflow streams into Prairie Lee Lake include the East Fork Little Blue River tributary, the East Fork Little Blue River, and an unnamed creek (fig. 2). The tailwater from Prairie Lee Lake flows directly into Lake Jacomo, where the dam was completed during 1959. The outflow from Lake Jacomo is uncontrolled and flows directly into Blue Springs Lake, which was filled during 1987. The morphometric characteristics of Prairie Lee Lake and Lake Jacomo are summarized in table 3.

Harrisonville City Lake (fig. 3; table 3) was formed by a man-made dam on Muddy Creek and was completed during 1972. The reservoir provides approximately 13,000 residents with drinking water and also is used as a public recreational (boating and fishing) facility for Cass County residents. The major inflow streams include North Fork of Muddy Creek, Muddy Creek, and South Fork of Muddy Creek (fig. 3). The outflow of Harrisonville City Lake also is uncontrolled.

\section{Hydrogeology}

The surficial geology of the three reservoir basins consists of shales and limestones of Pennsylvanian age of the Kansas City and Pleasanton Groups (Hasan and others, 1988). Outcrops along the edge of Prairie Lee Lake, Lake Jacomo, and Harrisonville City Lake consist primarily of Bethany Falls Limestone.

Table 3. Morphometric characteristics of three reservoirs in west-central Missouri

\begin{tabular}{|c|c|c|c|}
\hline Morphometric characteristic & Prairie Lee Lake ${ }^{1}$ & Lake Jacomo ${ }^{2}$ & Harrisonviiie City Lake ${ }^{3}$ \\
\hline Surface area (acres) & 140 & 1,050 & 416 \\
\hline Drainage area (acres) & 8,244 & 16,519 & 9,210 \\
\hline Shore length (miles) & 5.2 & 18.4 & 11.9 \\
\hline Total volume (acre-feet) & 2,860 & 20,800 & 6,930 \\
\hline Maximum depth (feet) & 46 & 52 & 42 \\
\hline Average depth (feet) & 20 & 20 & 17 \\
\hline $\begin{array}{l}\text { Shore line development (ratio of reservoir } \\
\text { perimeter to that of circle with equal area) }\end{array}$ & 3.1 & 4.1 & 4.2 \\
\hline
\end{tabular}


The report by the U.S. Geological Survey and Missouri Division of Geology and Land Survey (1967, p. 297) summarizes the ground-water characteristics of the area by "...the low permeability of the Pennsylvanian strata impedes ground-water movement both laterally and vertically. Because of this, there is very little opportunity for ground water recharge and discharge." Therefore, the role of ground-water contributions in the characteristics of the reservoirs was not included in the study because the contribution was judged to be insignificant relative to the contribution from surface-water sources.

\section{Soils}

The soils along the ridges in the Prairie Lee Lake and Lake Jacomo Basins are composed of gently sloping to moderately sloping soils of the MacksburgSharpsburg-Sampsel association (Preston, 1984). The surface layer is composed of silty clay loam and silt loam with subsoils of silty clay and silty clay loam. Soils in this association are moderately well drained to poorly drained. The Snead-Menfro-Oska association also is present in upland areas and consists of silty clay loam and silt loam with subsoils of silty clay and silty clay loam. Soils in this association are moderately well drained. Soils in both associations are moderately erodible.

The Snead-Polo-Oska association is on ridgetops and sideslopes in the Harrisonville City Lake Basin, and soils of this association are well to moderately well drained (Simmons, 1985). Surface layers in this association consist of silty clay loam and silt loam with a subsoil of silty clay loam and silty clay. The Zook-Blackoar-Verdigris association is present along floodplains, and soils of this association are moderately to poorly drained. Surface layers consist of silty clay loam and silty loam with subsoils of silt loam and silty clay loam. The Macksburg-Sampsel-Greenton association is present in gently sloping and moderately sloping areas, and the soils are poorly drained. Surface layers consist of silt loam and silty clay loam with a subsoil of silty clay loam and silty clay. Soils in these associations are moderately erodible.

\section{Land Use}

Land use in the Prairie Lee Lake Basin is about 41 percent urban, 36 percent pasture, 15 percent cropland, 6 percent forest, and 2 percent water (Willis Staller, Jackson County Parks and Recreation Depart- ment, written commun., 1991). Adjacent to the reservoir are two public access areas of about 280 total acres. Most of the property adjacent to the reservoir is privately owned and residences line much of the shoreline. Land use in the East Fork Little Blue River Basin and unnamed creek basin (fig. 2) upstream from Prairie Lee Lake is largely urban and growth has stabilized. The land use in the East Fork Little Blue River tributary Basin predominantly is pasture with some stable urbanized areas, although numerous residential development projects are either under construction or pending approval. Land use in the Lake Jacomo Basin (excluding the Prairie Lee Lake Basin) is 33 percent open grasslands, 27 percent forest, 20 percent cropland, 13 percent water, and 7 percent urban (Willis Staller, written commun., 1991).

The primary land use in the Harrisonville City Lake Basin is agriculture. Approximately 50 percent of the basin is in crops, 42 percent is in pasture, 6 percent is in forest, 1 percent is urban, and 1 percent is in other miscellaneous uses (Karrie Clutter, Cass County Soil and Watershed Conservation District, written commun., 1992).

\section{METHODS OF STUDY}

The methods used in collecting and analyzing the various physical, chemical, and biological data are discussed in the following sections. The same methods were used in data collection at all three reservoirs.

\section{Physical Characteristics}

A bathymetric survey of the three reservoirs determined the water depth and other morphometric characteristics (table 3). During the bathymetric survey, a theodolite equipped with an electronic distance meter and data transmitter was located on shore to track the horizontal position of a boat equipped with a fathometer, data logger, and data receiver as the boat travelled across all navigable surface areas of the reservoirs. The horizontal position of the boat and corresponding water depth were stored instantaneously on the data logger. The data logger operator controlled the timing at which the data points of the boat position and water depth were stored and the number of points stored. The data points were downloaded onto a laptop computer and transferred to the U.S. Geological Survey computer system where a geographic information 
system (GIS) was used to generate the bathymetric maps.

Sediment-depth surveys, in addition to determining the sediment depth, provided data that were used to estimate the volume of sediment deposited since the formation of the reservoirs. The sedimentdepth surveys in Prairie Lee Lake and Lake Jacomo were conducted in May 1992, and the survey in Harrisonville City Lake was conducted in April 1993. A boat crew collected sediment depths by manually driving sections of 0.5 -in. (inch) diameter rod into the reservoir bed material. The original reservoir bottom was estimated to be located at the point of refusal at the reservoir bottom (Rausch and Heinemann, 1968). In deeper water [greater than $20 \mathrm{ft}$ (feet)] where it was impractical to use long lengths of 0.5 -in. diameter pipe, a gravity corer modified to accept the 0.5 -in. diameter pipe was used. The corer was raised with a boom and reel mounted on a pontoon boat. The coring device, which weighed approximately $65 \mathrm{lb}$ (pounds), was allowed to free fall through the water and sediment column. The point to refusal was determined from a depth indicator on the reel. The sediment depth was determined by subtracting the current reservoir depth from the depth to refusal. At locations where the water was between 15 and $25 \mathrm{ft}$ deep, both manual and corer methods could be used. The number of sediment-depth points at each reservoir was determined by the size of the reservoir and the variability in sediment depths. The number of points on the reservoirs ranged from 50 at Prairie Lee Lake to 101 at Harrisonville City Lake. The boat location at each sediment-depth point was plotted on a 7.5-minute topographic map. The data point depicting the sample location was later digitized and entered into the GIS with the sedimentdepth information to create a coverage of the original lake bottom. The difference between the current reservoir bottom coverage and the original reservoir bottom coverage, or the volume of sediment deposited, was calculated using a statistical function of the GIS.

Water-clarity data were collected to determine the major factors controlling water clarity in the reservoirs. Water-clarity data, including Secchi disk depth (hereafter referred to as Secchi depth) and total suspended solids, suspended sediment, and chlorophyll $a$ concentrations, were determined at each reservoir site. Secchi depth is a measure of water transparency. A 20$\mathrm{cm}$ (centimeter) diameter white disk was lowered through the water column until the disk disappeared from sight and then the disk was raised until it was vis- ible again. The average of the two depths was the Secchi depth. Thus, the smaller the Secchi depth, the less transparent the water. Water samples were collected using a Teflon Kemmerer ${ }^{1}$ or Van-Dorn type point sampler following the sampling recommendations of Ward and Harr (1990). Chlorophyll samples were collected at all surface sites using a U.S. Geological Survey $\mathrm{DH}-48$ sampler over the depth corresponding to the Secchi depth. The suspended solids samples were analyzed by the U.S. Geological Survey laboratory in Arvada, Colorado, in accordance with methods described by Fishman and Friedman (1989). Suspended sediment analyses were conducted at the U.S. Geological Survey, Rolla, Missouri, using methods described by Guy (1969). Chlorophyll analyses were conducted at the U.S. Geological Survey laboratory in Arvada, Colorado, in accordance with methods described in Britton and Greeson (1987).

\section{Chemical Characteristics}

Physical properties and chemical constituents determined from sample points in the water column at each reservoir site included specific conductance, $\mathrm{pH}$, alkalinity, temperature, dissolved oxygen, total (unfiltered) $\mathrm{N}$ species, total $\mathrm{P}$, and orthophosphate $\left(\mathrm{PO}_{4}\right)$. Water samples were collected in the same manner and frequency as were water-clarity samples. Temperature and dissolved oxygen concentrations were measured onsite with an electronic meter at 2-ft intervals during stratification and 5-ft intervals during remaining periods. All instruments were calibrated using methods recommended by the manufacturers and the U.S. Geological Survey. Nutrient samples were analyzed by the U.S. Geological Survey laboratory in Arvada, Colorado, according to methods described by Fishman and Friedman (1989).

In addition to the above physical properties and chemical constituents, water samples at Harrisonville City Lake were analyzed for pesticides, including triazine herbicides. Water samples that were to be analyzed for triazine herbicides were collected monthly at the same time and location as the other samples. These samples were collected using a Teflon Kemmerer sampler and analyzed by the U.S. Geological Survey laboratory in Lawrence, Kansas, by gas chromatography/

\footnotetext{
${ }^{1}$ Use of brand names in this report is for identification purposes only and does not constitute endorsement by the U.S. Geological Survey.
} 
mass spectrometry using solid-phase extraction techniques described by Thurman and others (1990).

Additional water samples were collected monthly at Harrisonville City Lake from October 1992 through March 1993 at the three surface sites and analyzed for pesticides by the U.S. Environmental Protection Agency laboratory in Kansas City, Kansas, using methods described in a report by the U.S. Environmental Protection Agency (1988).

Bottom sediment samples were collected at three sites in each of the reservoirs using a U.S. Geological Survey BMH-54 bottom material sampler. Samples were analyzed for total N, total P, trace elements, and pesticides. Bottom sediment samples were collected once at Prairie Lee Lake and Lake Jacomo and three times at Harrisonville City Lake. Inorganic analyses of all sediment samples were conducted by the U.S. Geological Survey laboratory, Arvada, Colorado, using methods described by Fishman and Friedman (1989). Organic analyses of the bottom sediment samples from Prairie Lee Lake, Lake Jacomo, and Harrisonville City Lake (for samples collected in October 1992) were conducted by the U.S. Geological Survey laboratory, Arvada, Colorado, using methods described by Wershaw and others (1987). Analyses of the additional six bottom sediment samples from Harrisonville City Lake were conducted by the U.S. Environmental Protection Agency laboratory in Kansas City, Kansas, using methods described in a report by the U.S. Environmental Protection Agency (1988).

\section{Biological Characteristics}

Fecal coliform and fecal streptococcal bacteria densities were determined for the water column of each reservoir and for stormwater-runoff samples collected at inflow and outflow sites. The membrane filter method was used to determine bacteria densities (Britton and Greeson, 1987).

Phytoplankton samples were collected at all three surface sites on Prairie Lee Lake and Lake Jacomo from May 1991 through September 1992 and at all three surface sites on Harrisonville City Lake from May through October 1992. A 1-L (liter) water sample was collected using a U.S. Geological Survey DH-48 depth-integrated sampler to the same depth as the Secchi depth. The sample was treated with $10 \mathrm{~mL}$ (milliliters) of Lugol's solution ${ }^{2}$ as a preservative. Phytoplankton samples collected from May 14 through June 12, 1991, were analyzed by Chadwick and Associates, Littleton, Colorado. Subsequent phytoplankton samples were analyzed at Southwest Missouri State University in Springfield.

Zooplankton samples were collected at Harrisonville City Lake from May through October 1992, using procedures described by Britton and Greeson (1987). Samples were collected using a 202- $\mu \mathrm{m}$ (micrometer) plankton net at a single vertical section through the entire water column at each of the three sampling sites. Samples were preserved with 5 percent neutral formalin solution. Zooplankton samples were analyzed at Southwest Missouri State University.

\section{Reservoir Inflow and Outflow and Precipitation}

Monitoring of reservoir inflow and outflow included quantitative measurements of discharge and determination of physical properties, nutrients, and fecal coliform and fecal streptococcal bacteria densities. The inflow sites were monitored monthly and during three storms. The outflow sites were sampled only during three storms. Sampling sites in the Prairie Lee Lake and Lake Jacomo Basins were located at three tributaries to Prairie Lee Lake, the Prairie Lee Lake outflow (site PL4), and the Lake Jacomo outflow (site LJ4; fig. 2; table 2). Three tributaries of Harrisonville City Lake and the outflow downstream from the outflow (site HL4) were sampled (fig. 3; table 2).

Staff gages and continuous-record gages were used to monitor reservoir inflows and outflows. The inflow sites were equipped with staff gages, and discharge was measured to generate a stage-discharge rating curve. The surface elevations of Prairie Lee Lake, Lake Jacomo, and Harrisonville City Lake were recorded with continuous-record gages. The outflows of the three reservoirs were measured to generate an elevation-discharge rating curve between reservoir elevation (stage) and reservoir outflow discharge.

The chemical characteristics of inflow and outflow water samples were determined from both monthly and stormwater-runoff samples. Water samples were collected monthly at the inflow sites and analyzed for $\mathrm{N}$ and $\mathrm{P}$ species concentrations and suspended sediment concentration. Samples were collected using the equal-width-increment (EWI) method

\footnotetext{
${ }^{2} \mathrm{~A}$ staining and preservative solution for phytoplankton composed of iodine crystals, potassium iodide, acetic acid, and distilled water (Rodhe and others, 1958).
} 
(Guy and Norman, 1970). Multiple samples collected during the storms using the EWI method were composited on the basis of the part of the total discharge hydrograph that was represented by the sample. The sample representing the largest part of the discharge hydrograph was given full weight; the full volume was used in the composite, and the remaining samples were proportioned accordingly. The flow-weighted composite storm sample was analyzed for $\mathrm{N}$ and $\mathrm{P}$ species, suspended sediment, and suspended volatile solids concentrations. Grab samples were collected in sterilized sample bottles at the centroid of flow during stormwater-runoff sampling for the determination of fecal coliform and fecal streptococcal bacteria densities.

Precipitation data for the Prairie Lee Lake and Lake Jacomo Basins were collected from May 1991 to April 1992 at the James A. Reed Memorial Wildlife Area in Lee's Summit (table 4). Precipitation data for the Harrisonville City Lake Basin were collected at Harrisonville City Lake from April 1992 through July 1993.

\section{PHYSICAL CHARACTERISTICS}

Physical characteristics of the three reservoirs, which were measured during the investigation, are described in the following sections. These characteristics include water depth, sediment thickness, and water clarity.

\section{Water Depth}

The water-depth information collected from the three reservoirs was used to construct bathymetric maps (fig. 4), depth-area curves (hypsographic curves), and depth-capacity curves for each reservoir (fig. 5). This information aids in the recreational use of the reservoirs and in determining the hydrologic characteristics of the reservoirs. Using the depth-area and depth-capacity curves for Prairie Lee Lake (fig. 5), it can be determined, for example, that at a depth of $30 \mathrm{ft}$ the reservoir would have a surface area that is about 30 percent of the total surface area at the time of the bathymetric survey (140 acres) and 12 percent of the total reservoir capacity [2,860 acre-ft (acre-feet)].

Table 4. Precipitation data for James A. Reed Memorial Wildlife Area in Lee's Summit, Missouri, May 1991-April 1992, and Harrisonville City Lake, near Harrisonville, Missouri, April 1992-July 1993

\begin{tabular}{|c|c|c|c|}
\hline & James A. Reed Memorlal Wild life Area & & Harrisonville Clty Lake \\
\hline Date & $\begin{array}{l}\text { Monthly precipitation, } \\
\text { May 1991-April 1992, } \\
\text { In inches }\end{array}$ & Date & $\begin{array}{l}\text { Monthly preclpitatlon, } \\
\text { Aprll 1992-March 1993, } \\
\text { In Inches }\end{array}$ \\
\hline May 1991 & 6.73 & April 1992 & 5.60 \\
\hline June 1991 & 1.42 & May 1992 & 1.40 \\
\hline July 1991 & 3.68 & June 1992 & 3.39 \\
\hline August 1991 & 1.89 & July 1992 & 4.99 \\
\hline September 1991 & 7.08 & August 1992 & 2.95 \\
\hline October 1991 & 3.44 & September 1992 & 3.00 \\
\hline November 1991 & 3.08 & October 1992 & 2.50 \\
\hline December 1991 & 1.79 & November 1992 & 8.85 \\
\hline January 1992 & .67 & December 1992 & 5.40 \\
\hline February 1992 & 1.79 & January 1993 & 1.65 \\
\hline March 1992 & 3.78 & February 1993 & 2.45 \\
\hline \multirow[t]{5}{*}{ April 1992} & 5.57 & March 1993 & 2.05 \\
\hline & & April 1993 & 5.50 \\
\hline & & May 1993 & 6.90 \\
\hline & & June 1993 & 4.10 \\
\hline & & July 1993 & 16.90 \\
\hline
\end{tabular}




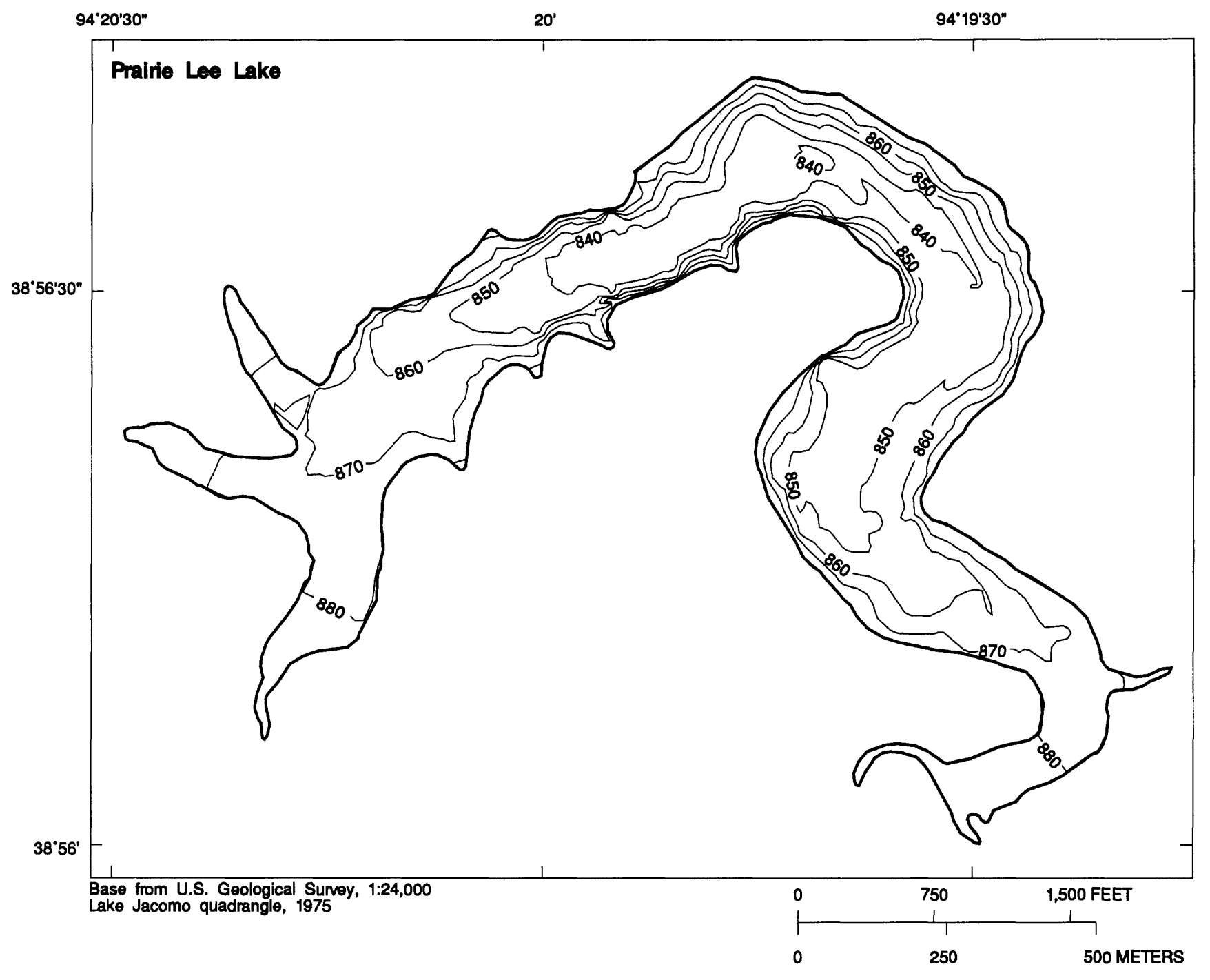

EXPLANATION

- $850-$ BATHYMETRIC CONTOUR--Shows altitude

interval 10 feet. Datum is sea level

Fgure 4. Bathymetric maps of three reservoirs in west-central Missouri. 


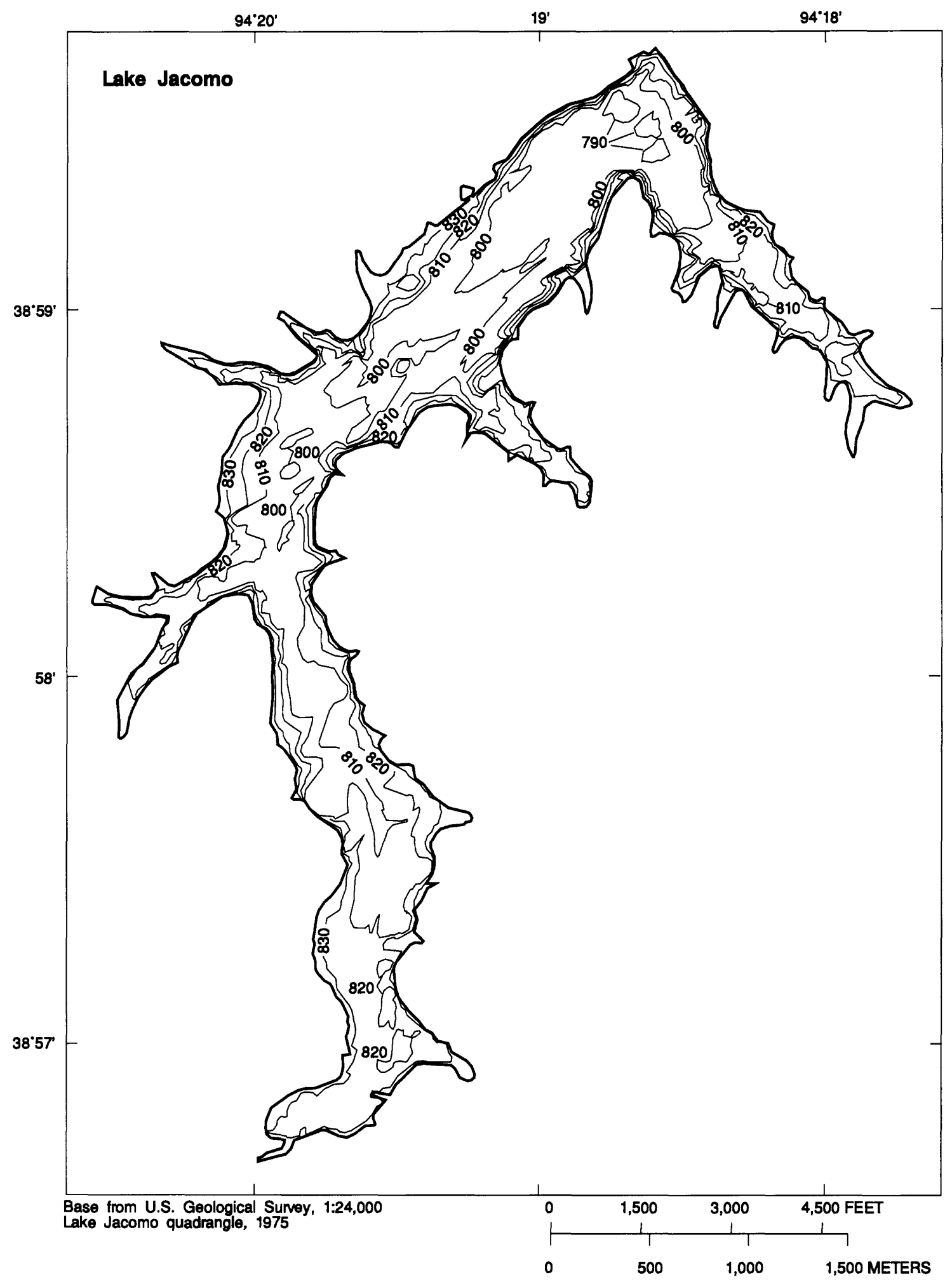

Figure 4. Bathymetric maps of three reservoirs in west-central Missouri--Continued. 


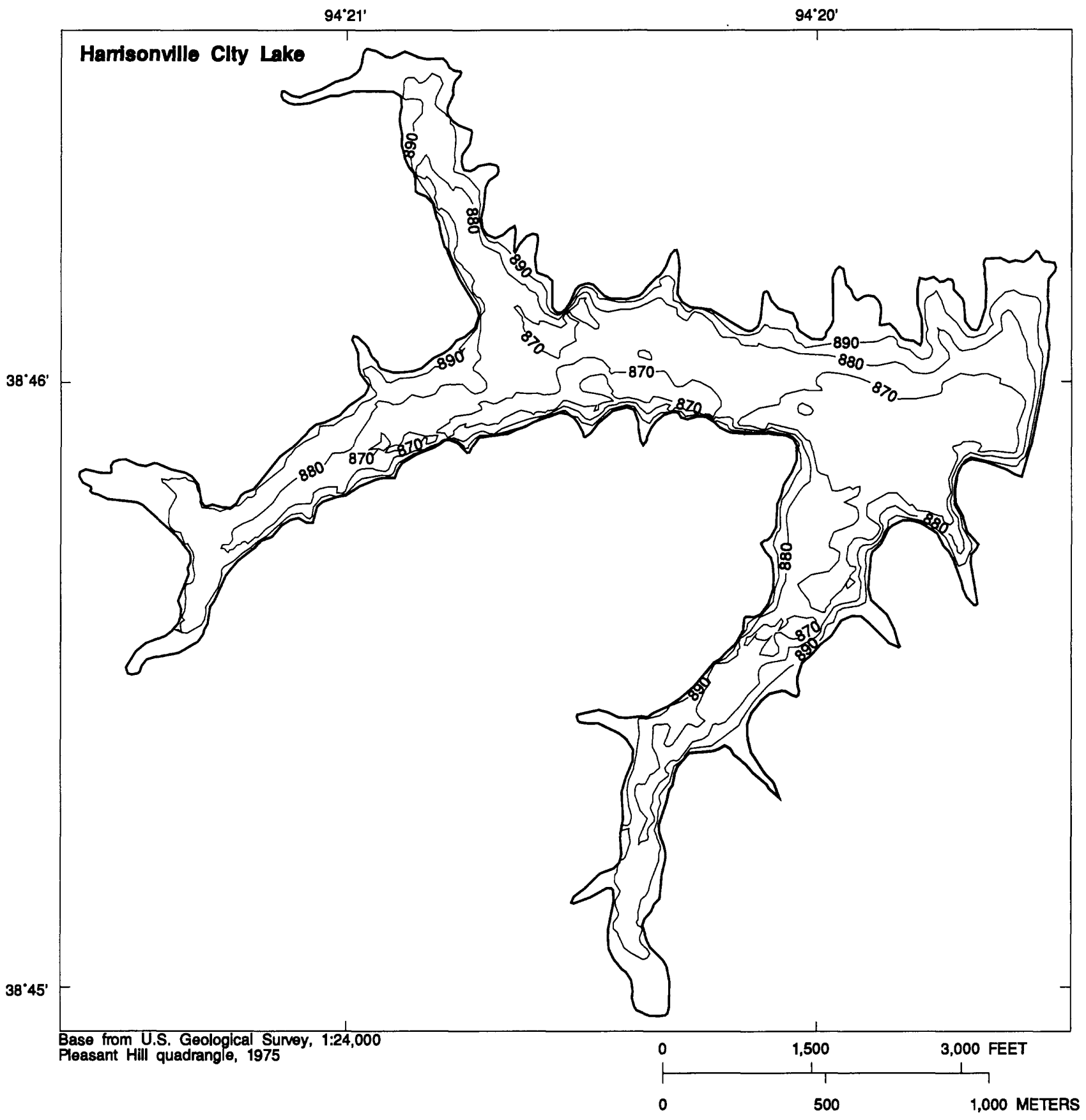

Fgure 4. Bathymetric maps of three resenvirs in west-central Missouri--Continued. 

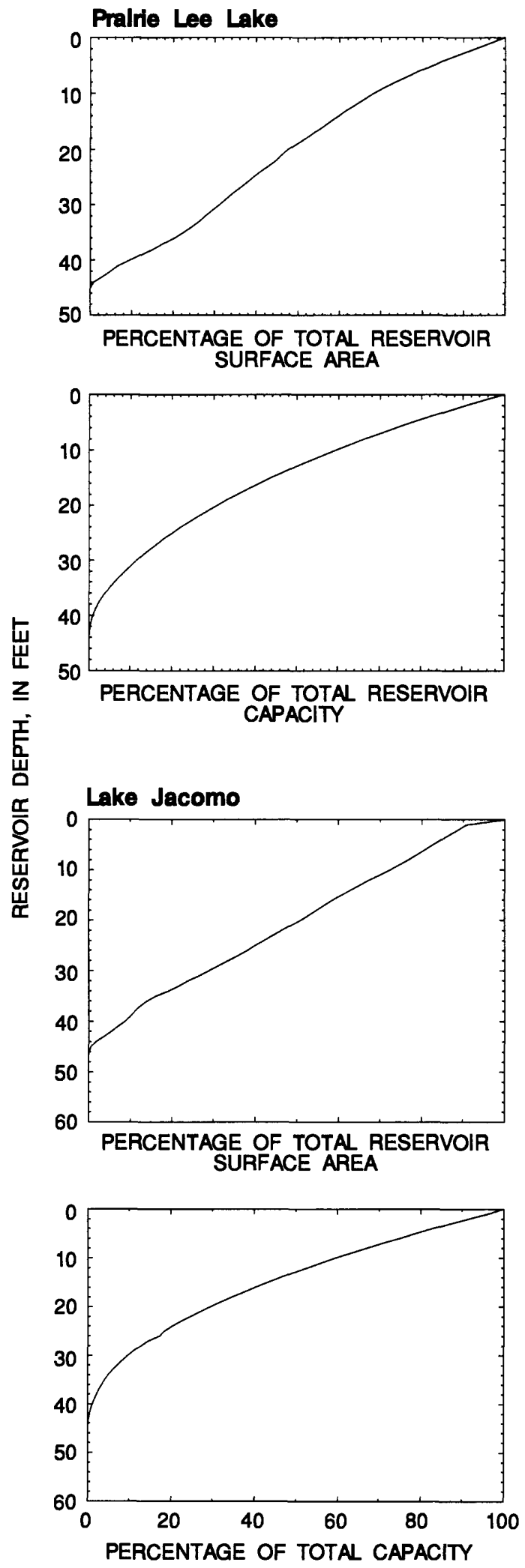

Figure 5. Depth-area and depth-capacity curves of three resenvirs in west-central Missouri.

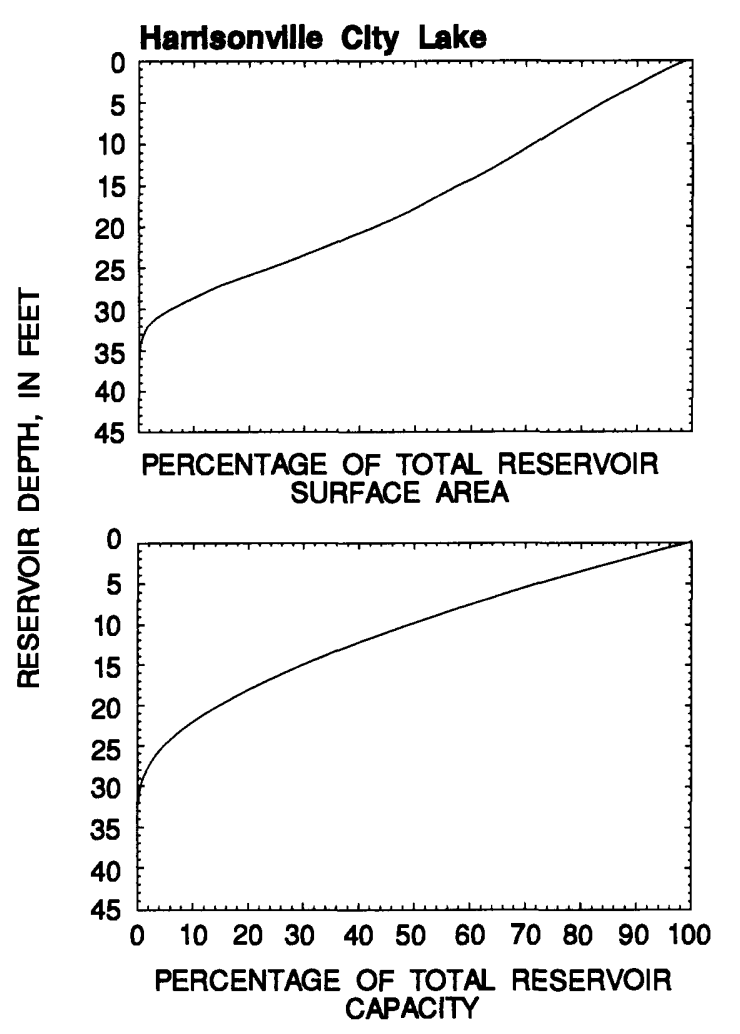

Figure 5. Depth-area and depth-capacity curves of three reservoirs west-central Missouri--Continued.

The total reservoir capacity and inflow volume can be used to determine the hydraulic residence time in a reservoir. The hydraulic residence time is a quantitative measurement of the time required to displace the volume of a reservoir with inflow volume. The result was calculated using the following equation:

$$
R T=\frac{V}{(D A)(R)},
$$

where

RT is hydraulic residence time, in years;

$\mathrm{V}$ is volume of reservoir, in acre-feet;

DA is drainage area of reservoir basin, in acres; and

$R$ is runoff from basin, in feet per year.

The volume of the reservoir was determined from the bathymetric survey. The long-term mean values of runoff $(\mathrm{R})$ for the East Fork Little Blue River Basin were obtained from Gerbert and others (1989) and from mean runoff values calculated from seven continuous-record gaging stations in Missouri and Kansas located near the study area. The mean runoff values were weighted based on years of record (table 5; U.S. Geological Survey, 1954-91). A mean annual runoff value of $0.72 \mathrm{ft} / \mathrm{yr}$ (foot per year) was obtained from Gerbert and others (1989), and the mean annual runoff 
Table 5. Associated continuous-record gaging station data used in calculating mean annual runoff for study basins [in/yr, inches per year; $\mathrm{ft} / \mathrm{yr}$, foot per year]

\begin{tabular}{lccc}
\hline \multicolumn{1}{c}{$\begin{array}{c}\text { Statlon } \\
\text { (fig. 1) }\end{array}$} & $\begin{array}{c}\text { Years of } \\
\text { record }^{\mathbf{1}}\end{array}$ & $\begin{array}{c}\text { Mean runoff } \\
\text { (In/yr) }\end{array}$ & $\begin{array}{c}\text { Welghted runoff }^{\mathbf{3}} \\
\text { (In/yr) }\end{array}$ \\
\hline South Grand River at Archie, Missouri & 18 & 11.48 & 1.55 \\
Blue River near Stanley, Kansas & 18 & 9.51 & 1.29 \\
East Fork Little Blue River below Longview Lake, Missouri & 20 & 11.14 & 1.68 \\
East Fork Little Blue River near Blue Springs, Missouri & 15 & 11.10 & 1.25 \\
Little Blue River near Lake City, Missouri & 37 & 11.05 & 3.07 \\
Big Creek near Blairstown, Missouri & 15 & 10.40 & 1.17 \\
Sni-A-Bar Creek near Tarsney, Missouri & 10 & 10.55 & .79 \\
\hline
\end{tabular}

${ }^{1}$ Represents periods when streamflow was not regulated by reservoirs.

${ }^{2}$ Data from U.S. Geological Survey (1954-91).

${ }^{3}$ Weighted mean annual runoff $=10.8 \mathrm{in} / \mathrm{yr}=0.90 \mathrm{ft} / \mathrm{yr}$.

value determined from the seven continuous-record gaging stations was $0.90 \mathrm{ft} / \mathrm{yr}$ (table 5).

The calculated hydraulic residence times for the three reservoirs are listed in table 6. Prairie Lee Lake has the lowest hydraulic residence time of 0.38 to 0.49 year, depending on the runoff value used; the reservoir receives a mean annual inflow volume equivalent to about two to three times its capacity. Lake Jacomo, which has a hydraulic residence time of 1.40 to 1.76 years, receives a mean annual inflow volume equivalent to about 60 to 70 percent of its capacity. Harrisonville City Lake has a hydraulic residence time of 0.84 to 1.05 years and receives a mean annual inflow volume approximately equal to the reservoir capacity.

\section{Sediment Thickness}

Sedimentation historically has been a concern in both Prairie Lee Lake and Lake Jacomo, and dredging operations were undertaken during the 1970 's to alleviate the effects of sedimentation in the more intensely affected areas (Willis Staller, written commun., 1991; table 7). Sediment decreases recreational opportunities in the reservoirs by limiting access to areas of the reservoirs. Sediment also decreases water clarity, the capacity, and "life expectancy" of the reservoir. Sediment deposits in excess of $12 \mathrm{ft}$ were measured in the southeast arm of Prairie Lee Lake during the 1992 sedimentation survey (fig. 6) despite dredging operations that took place in this arm during 1973 and 1978 (table 7). Water depths in the upstream reach of the southeast arm of Prairie Lee Lake following dredging were about $6 \mathrm{ft}$ (Willis Staller, oral commun., 1993). Based on post-dredging water depths in the southeast arm and measured maximum water depths during 1992 of 0 to $2 \mathrm{ft}$, more than $4 \mathrm{ft}$ of sediment have been deposited in this arm since the last dredging operation during 1978. This thickness of sediment indicates an estimated average deposition rate of about $0.3 \mathrm{ft} / \mathrm{yr}$ during 14 years. A large quantity of sediment also has been deposited on the southwest arm of the reservoir, although the areal extent and thickness are not as great as the extent and thickness in the southeast arm. A total of 3 acres or 2 percent of the total surface area of Prairie Lee Lake has been lost because of sedimentation in the reservoir. This is based on the comparison of the 1992 surface to that depicted on the 1975 revi-

Table 6. Hydraulic residence times for three reservoirs in west-central Missouri

\begin{tabular}{lcc}
\hline $\begin{array}{c}\text { Reservoir } \\
\text { (figs. 1 and 2) }\end{array}$ & $\begin{array}{c}\text { Hydraulic residence time using } \\
\text { annual runoff values from } \\
\text { Gebert and others (1989), } \\
\text { in years }\end{array}$ & $\begin{array}{c}\text { Hydraullc residence tIme using annual } \\
\text { runoff values computed from seven } \\
\text { continuous-record gaging statlons, } \\
\text { In years }\end{array}$ \\
\hline Prairie Lee Lake & 0.49 & 0.38 \\
Lake Jacomo & 1.76 & 1.40 \\
Harrisonville City Lake & 1.05 & .84 \\
\hline
\end{tabular}


Table 7. Sediment dredging record, Prairie Lee Lake and Lake Jacomo, west-central Missouri, 1973-80

\begin{tabular}{lcc}
\hline $\begin{array}{c}\text { Location } \\
\text { (fig. 6) }\end{array}$ & Year & $\begin{array}{c}\text { Estlmated quantity removed } \\
\text { (acre-feet) }\end{array}$ \\
Southeast arm & Prairie Lee Lake & 3.9 \\
Southeast arm & 1973 & 14.8 \\
& 1978 & 18.7 \\
& Total & \\
Liggett Cove & Lake Jacomo & 2.0 \\
Rotary Camp Cove & 1974 & 3.0 \\
South Boat Basin & 1975 & .3 \\
Liggett Cove & 1976 & 10.9 \\
Sailboat Cove & 1977 & 2.0 \\
Cove 10 & 1977 & 1.0 \\
& 1980 & 19.2 \\
\hline
\end{tabular}

sion of the topographic map of the area. The volume of sediment calculated from the sediment-depth survey was 1,160 acre-ft, which equates to a 29 percent loss in the original reservoir volume. About 19 acre- $\mathrm{ft}$ of sediment were removed during the 1973 and 1978 dredging operations. Therefore, a total of about 1,180 acre- $\mathrm{ft}$ of sediment has been deposited in the 53 years since the reservoir was filled, and this value corresponds to an average deposition rate of about $0.15 \mathrm{ft} / \mathrm{yr}$ over the entire area of the reservoir.

In Lake Jacomo the greatest sediment deposition has occurred in the west-central arm of the reservoir where more than $9 \mathrm{ft}$ of sediment were measured. Other areas of thick sediment deposition include Sailboat and Liggett Coves (fig. 6). These areas were dredged in the mid-1970's (table 7). The volume of sediment calculated from the sediment-depth survey was 1,890 acre-ft or 8 percent of the original reservoir volume. A total of about 19 acre- $\mathrm{ft}$ of sediment was removed during the 1974 to 1980 dredging operations (table 7). An estimated total of about 1,910 acre-ft of sediment has been deposited in the 33 years since the reservoir dam was built. The average deposition rate for the entire reservoir is about $0.06 \mathrm{ft} / \mathrm{yr}$.

Although the sediment trap efficiency of Prairie Lee Lake was not determined in this study, this reservoir probably is a settling basin for Lake Jacomo by trapping suspended sediment in runoff. The sediment retention capacity of Prairie Lee Lake is limited, however, by the reservoir's relatively small capacity and short hydraulic residence time in comparison to the capacity and residence time of Lake Jacomo.

The areas of greatest deposition in the Harrisonville City Lake (fig. 6) include the northwest and southwest arms of the reservoir where more than $9 \mathrm{ft}$ of sediment were measured. An estimated 1,130 acre$\mathrm{ft}$ of sediment have been deposited in the 21 years since the reservoir was completed, resulting in a 14 percent loss in the original reservoir volume. The average sediment deposition rate over the entire reservoir is about $0.13 \mathrm{ft} / \mathrm{yr}$.

\section{Water Clarity}

The following section summarizes the results of measurements and analyses of water-clarity characteristics of the study reservoirs, including Secchi depth and total suspended solids, suspended sediment, and chlorophyll $a$ concentrations (table 8; fig. 7). The spatial variation in the median values of these characteristics within each individual reservoir was analyzed along with the degree of correlation between Secchi depth and total suspended solids, suspended sediment, and chlorophyll $a$ concentrations.

There were no significant differences between median Secchi depth values (table 8; fig. 7) determined from measurements at three surface sites within Prairie Lee Lake or at sites within Harrisonville City Lake. There was a significant difference between median values between sites within Lake Jacomo [Kruskal-Wallis test, $\alpha$ (alpha) $=0.05$ ] because of the 


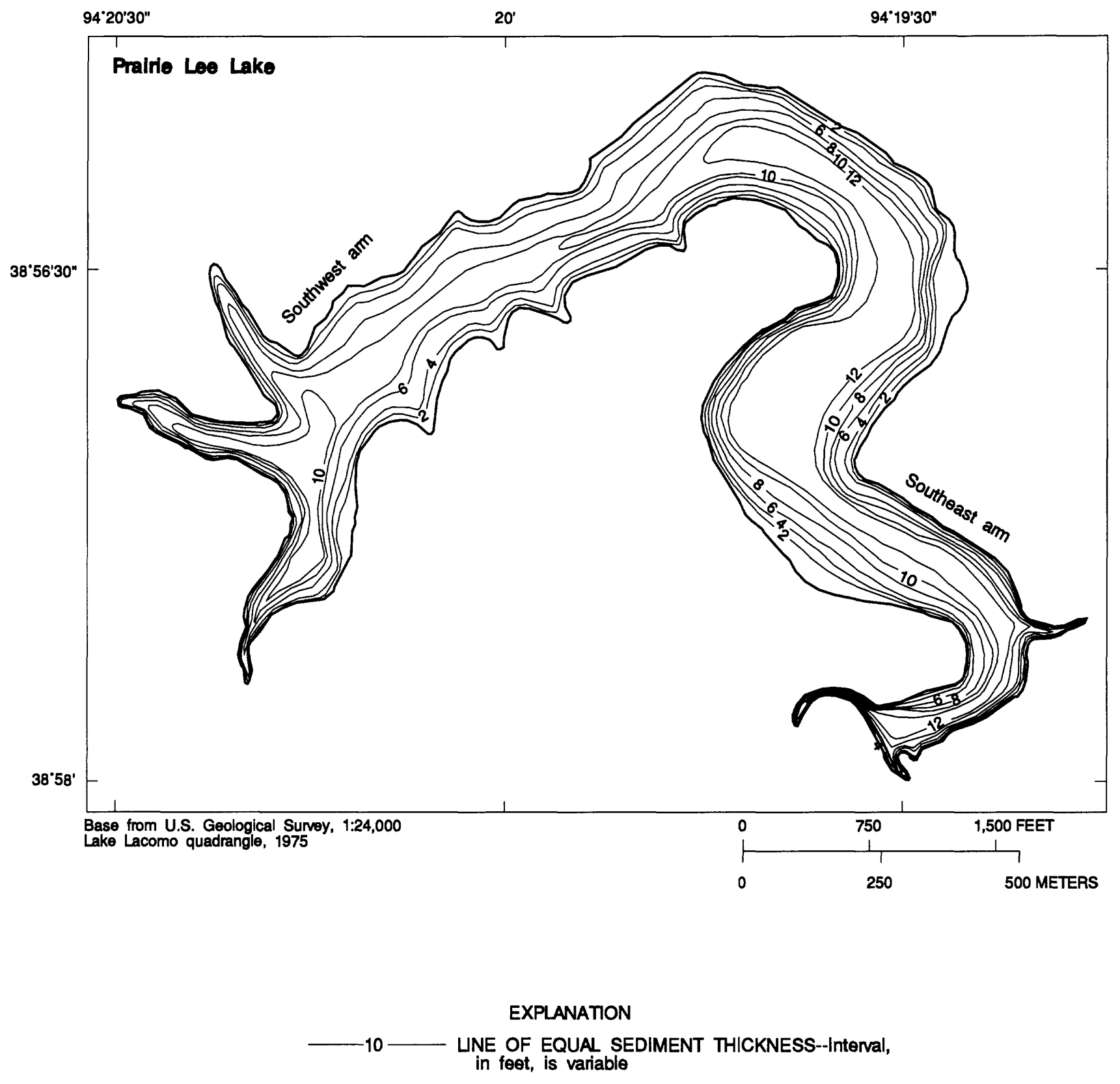

Figure 6. Sediment-thickness maps of three reservoirs in west-central Missouri. 


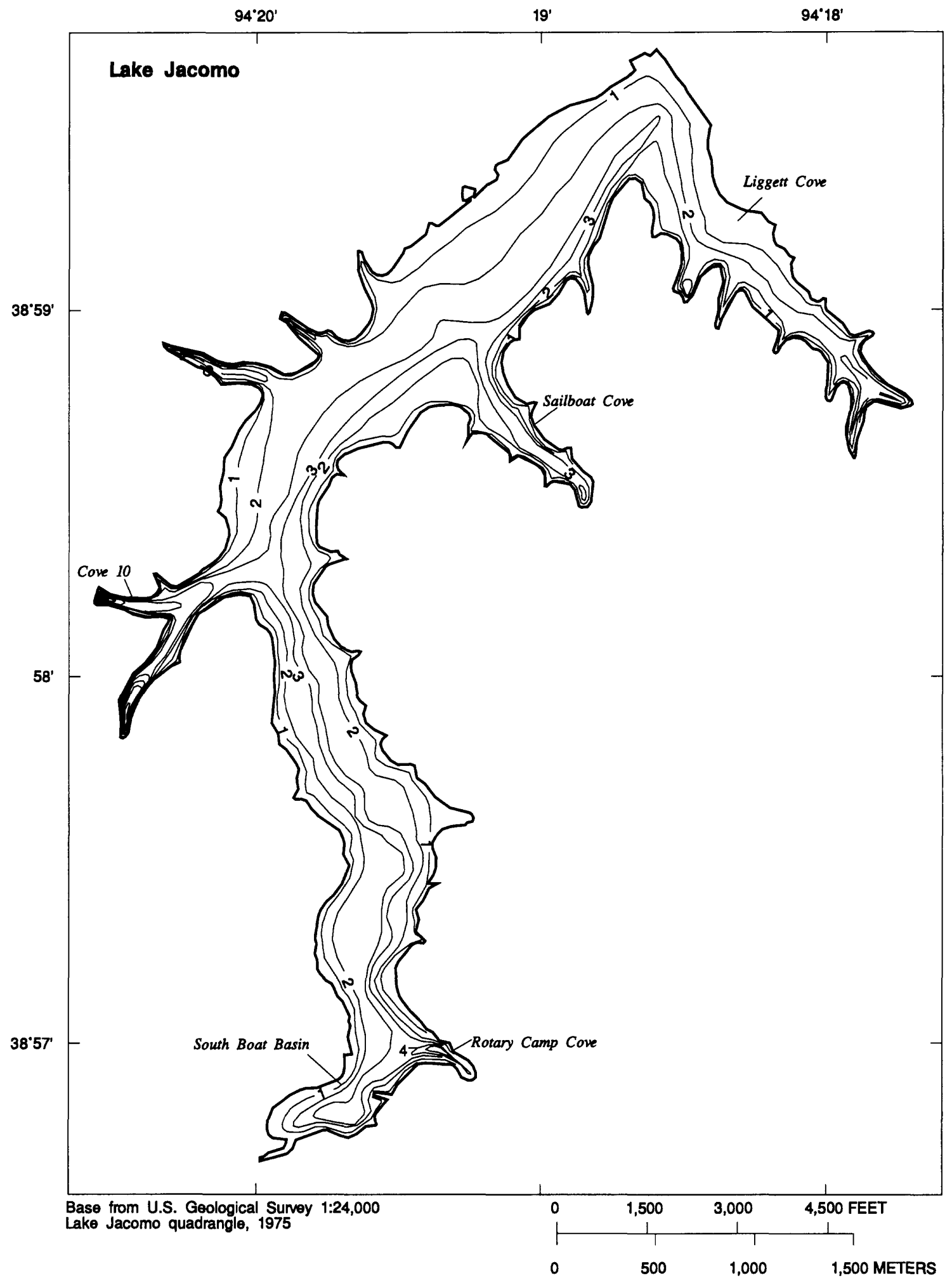

Figure 6. Sediment-thickness maps of three reservoirs in west-central Missouri--Continued. 


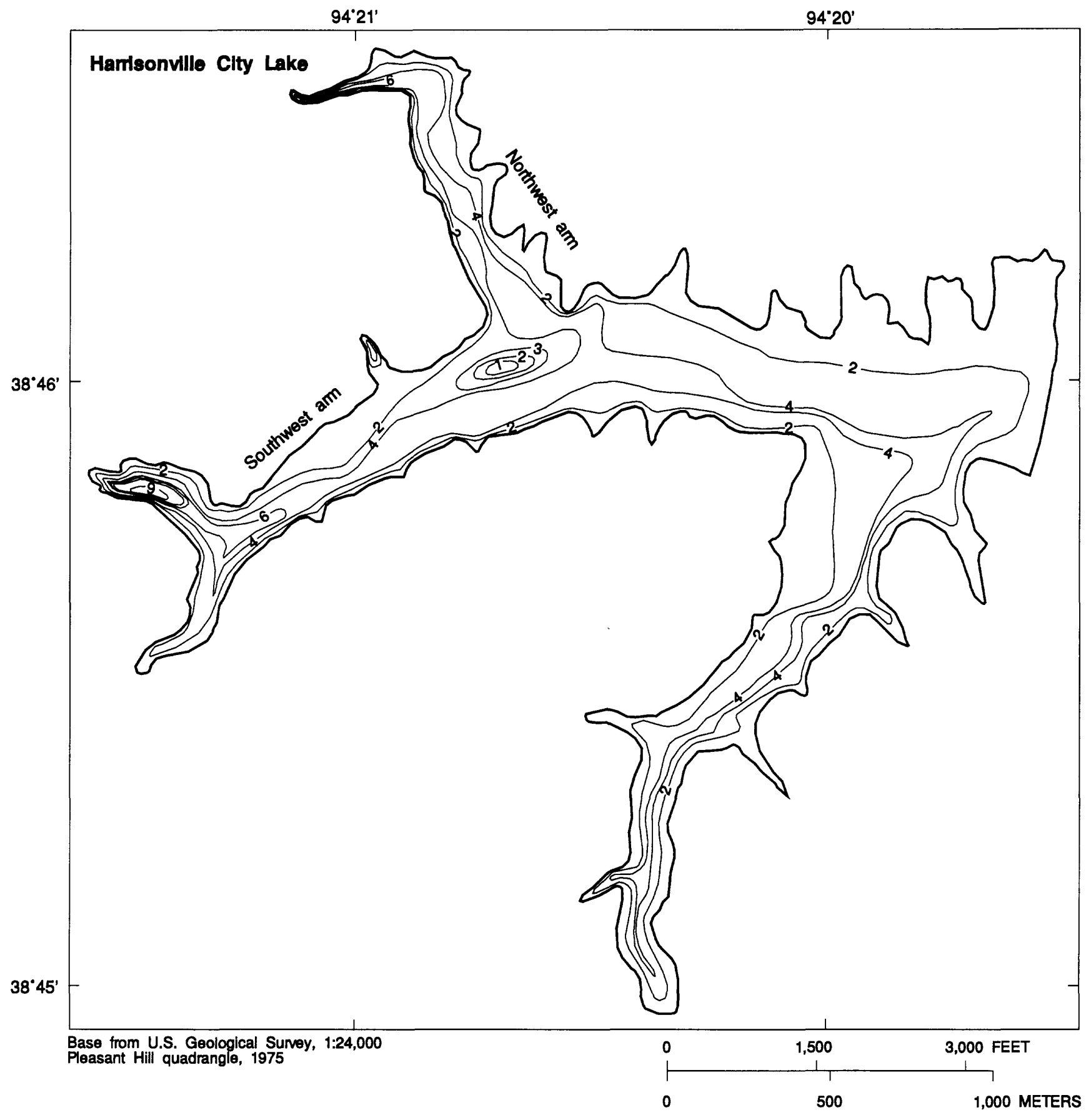

Figure 6. Sediment-thickness maps of three reservoirs in west-central Missouri--Continued. 
Table 8. Summary statistics of water-clarity characteristics in surface and bottom samples from three reservoirs in west-central Missouri

[ft, feet; mg/L, milligrams per liter, $\mu \mathrm{g} / \mathrm{L}$, micrograms per liter]

\begin{tabular}{lcccc}
\hline \multicolumn{1}{c}{ Water-clarlty characterlstlc } & $\begin{array}{c}\text { Number of } \\
\text { samples }\end{array}$ & Maxlmum & MInlmum & Medlan \\
\hline & Prairie Lee Lake--Site PL1 (southeast arm at surface) & & \\
Secchi depth $(\mathrm{ft})$ & 15 & 6.9 & 2.0 & 3.5 \\
Total suspended solids $(\mathrm{mg} / \mathrm{L})$ & 16 & 16 & 1 & 2 \\
Suspended sediment $(\mathrm{mg} / \mathrm{L})$ & 14 & 17 & 1 & 10 \\
Chlorophyll $a(\mu \mathrm{g} / \mathrm{L})$ & 16 & 26 & .4 & 7.2
\end{tabular}

Prairie Lee Lake--Site PL1 (southeast arm at bottom)

Total suspended solids $(\mathrm{mg} / \mathrm{L})$

Suspended sediment $(\mathrm{mg} / \mathrm{L})$

Secchi depth (ft)

Total suspended solids $(\mathrm{mg} / \mathrm{L})$

Suspended sediment $(\mathrm{mg} / \mathrm{L})$

Chlorophyll $a(\mu \mathrm{g} / \mathrm{L})$

Total suspended solids $(\mathrm{mg} / \mathrm{L})$

Suspended sediment $(\mathrm{mg} / \mathrm{L})$

Secchi depth (ft)

Total suspended solids ( $\mathrm{mg} / \mathrm{L}$ )

Suspended sediment $(\mathrm{mg} / \mathrm{L})$

Chlorophyll $a(\mu \mathrm{g} / \mathrm{L})$
16

13

1

8

1

12

Prairie Lee Lake--Site PL2 (near dam at surface)

$\begin{array}{cccc}17 & 6.6 & 2.2 & 3.5 \\ 15 & 14 & 1 & 2 \\ 14 & 15 & 4 & 10 \\ 17 & 23 & .4 & 6.2\end{array}$

Prairie Lee Lake--Site PL2 (near dam at bottom)

Prairie Lee Lake--Site PL3 (southwest arm at surface)

$\begin{array}{llll}16 & 39 & 1 & 10 \\ 15 & 56 & 1 & 21\end{array}$

Prairie Lee Lake--Site PL3 (southwest arm at bottom)

Total suspended solids (mg/L)

16

54

3

12

Suspended sediment $(\mathrm{mg} / \mathrm{L})$

14

149

3

27 
Table 8. Summary statistics of water-clarity characteristics in surface and bottom samples from three reservoirs in west-central Missouri-Continued

\begin{tabular}{lcccc}
\hline \multicolumn{1}{c}{ Water-ciarity characteristic } & $\begin{array}{c}\text { Number of } \\
\text { sampies }\end{array}$ & Maximum & Minimum & Median \\
\hline & Lake Jacomo--Site LJ1 (south site at surface) & & \\
Secchi depth $(\mathrm{ft})$ & 17 & 7.6 & 2.1 & 3.5 \\
Total suspended solids $(\mathrm{mg} / \mathrm{L})$ & 16 & 15 & 1 & 2 \\
Suspended sediment $(\mathrm{mg} / \mathrm{L})$ & 12 & 16 & 1 & 10 \\
Chlorophyll $a(\mu \mathrm{g} / \mathrm{L})$ & 17 & 11 & 2.2 & 7.7
\end{tabular}

Lake Jacomo--Site LJ1 (south site at bottom)

Total suspended solids $(\mathrm{mg} / \mathrm{L})$

16

14

36

30

12

Lake Jacomo--Site LJ2 (central site at surface)

Secchi depth (ft)

Total suspended solids $(\mathrm{mg} / \mathrm{L})$

Suspended sediment $(\mathrm{mg} / \mathrm{L})$

Chlorophyll $a(\mu \mathrm{g} / \mathrm{L})$

10.1

3.8

5.3

16

12

13

13

15

Lake Jacomo--Site LJ2 (central site at bottom)

Total suspended solids (mg/L)

Suspended sediment $(\mathrm{mg} / \mathrm{L})$

16

33

25

1

7

12

1

12

Lake Jacomo--Site LJ3 (near dam at surface)

Secchi depth (ft)

16

16

10.5

3.8

5.4

Total suspended solids (mg/L)

Suspended sediment (mg/L)

12

20

1

2

Chlorophyll $a(\mu \mathrm{g} / \mathrm{L})$

17

11

1

4

.4

5.3

Lake Jacomo--Site LJ3 (near dam at bottom)

Total suspended solids $(\mathrm{mg} / \mathrm{L}$ )

16

39

12

53

1

9

8 
Table 8. Summary statistics of water-clarity characteristics in surface and bottom samples from three reservoirs in west-central Missouri-Continued

\begin{tabular}{lcccc}
\hline \multicolumn{1}{c}{ Water-clarlty characteristic } & $\begin{array}{c}\text { Number of } \\
\text { sampies }\end{array}$ & Maximum & Minimum & Median \\
\hline & Harrisonville City Lake--Site HL1 (south arm at surface) & & \\
Secchi depth $(\mathrm{ft})$ & 10 & 4.5 & 2.3 & 3.2 \\
Total suspended solids $(\mathrm{mg} / \mathrm{L})$ & 10 & 28 & 1 & 8 \\
Suspended sediment $(\mathrm{mg} / \mathrm{L})$ & 12 & 17 & 3 & 7 \\
Chlorophyll $a(\mu \mathrm{g} / \mathrm{L})$ & 10 & 11 & 3.5 & 6.3
\end{tabular}

Harrisonville City Lake--Site HL2 (near dam at surface)

Secchi depth (ft)

Total suspended solids $(\mathrm{mg} / \mathrm{L})$

Suspended sediment $(\mathrm{mg} / \mathrm{L})$

Chlorophyll $a(\mu \mathrm{g} / \mathrm{L})$

\section{6}

16

17

16

27
1.7

1

.6

1.9
3.8

6

10

5.3

Harrisonville City Lake--Site HL2 (near dam at bottom)

Total suspended solids (mg/L)

Suspended sediment (mg/L)
15

16
28

59
1

3
9

20

Harrisonville City Lake--Site HL3 (west arm at surface)

Secchi depth (ft)

Total suspended solids (mg/L)

Suspended sediment $(\mathrm{mg} / \mathrm{L})$

Chlorophyll $a(\mu \mathrm{g} / \mathrm{L})$

\section{0}

10

12

9
5

18

22

9
2.1

3.0

10

10

3.9 lower median Secchi depth at site LJ1 relative to median values at sites $\mathrm{LJ} 2$ and $\mathrm{LJ} 3$. The transparency of the water at site $\mathrm{LJ} 1$ possibly is affected by the outflow from Prairie Lee Lake because the median Secchi depth seems closer to the median depths of PL1, PL2, and PL3 than to LJ2 and LJ3.

The median total suspended solids and suspended sediment concentrations were greater in bottom samples than in surface samples from the three reservoirs (table 8; fig. 7) because dead plankton, bacteria, and sediment in the surface layers settle into the bottom layers of the lakes. The differences in median concentrations of these properties between the three surface sites or between the bottom sites within an individual reservoir were not significant (KruskalWallis test, $\alpha=0.05$ ).

Chlorophyll $a$ is contained in all phytoplankton and is used as an indicator of phytoplankton biomass. 

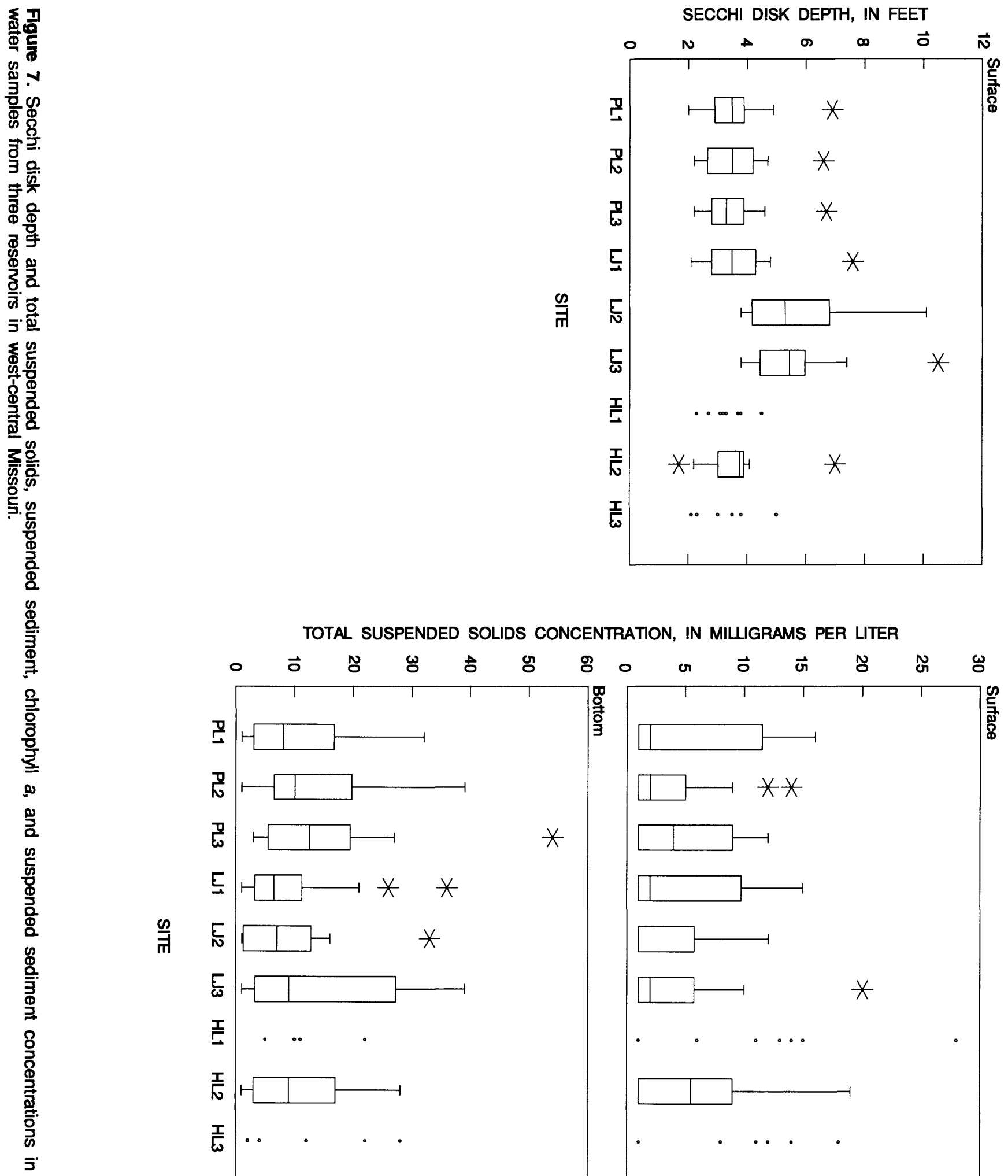

TOTAL SUSPENDED SOLIDS CONCENTRATION, IN MILIGRAMS PER LITER

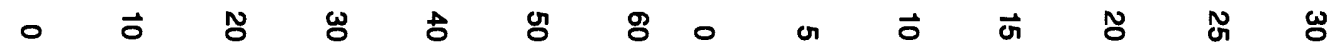

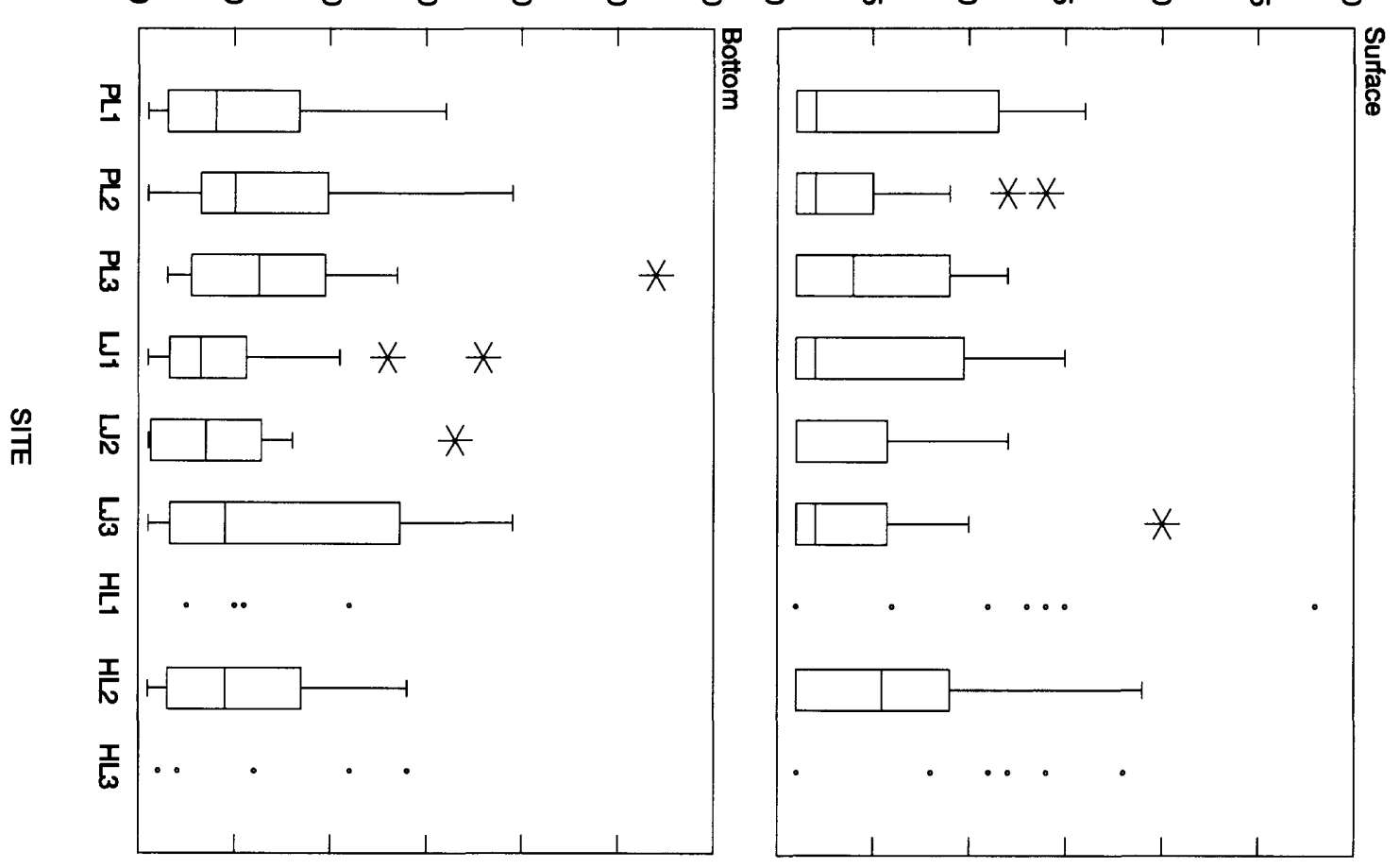


SUSPENDED SEDIMENT CONCENTRATION, IN MIUGRAMS PER LTER

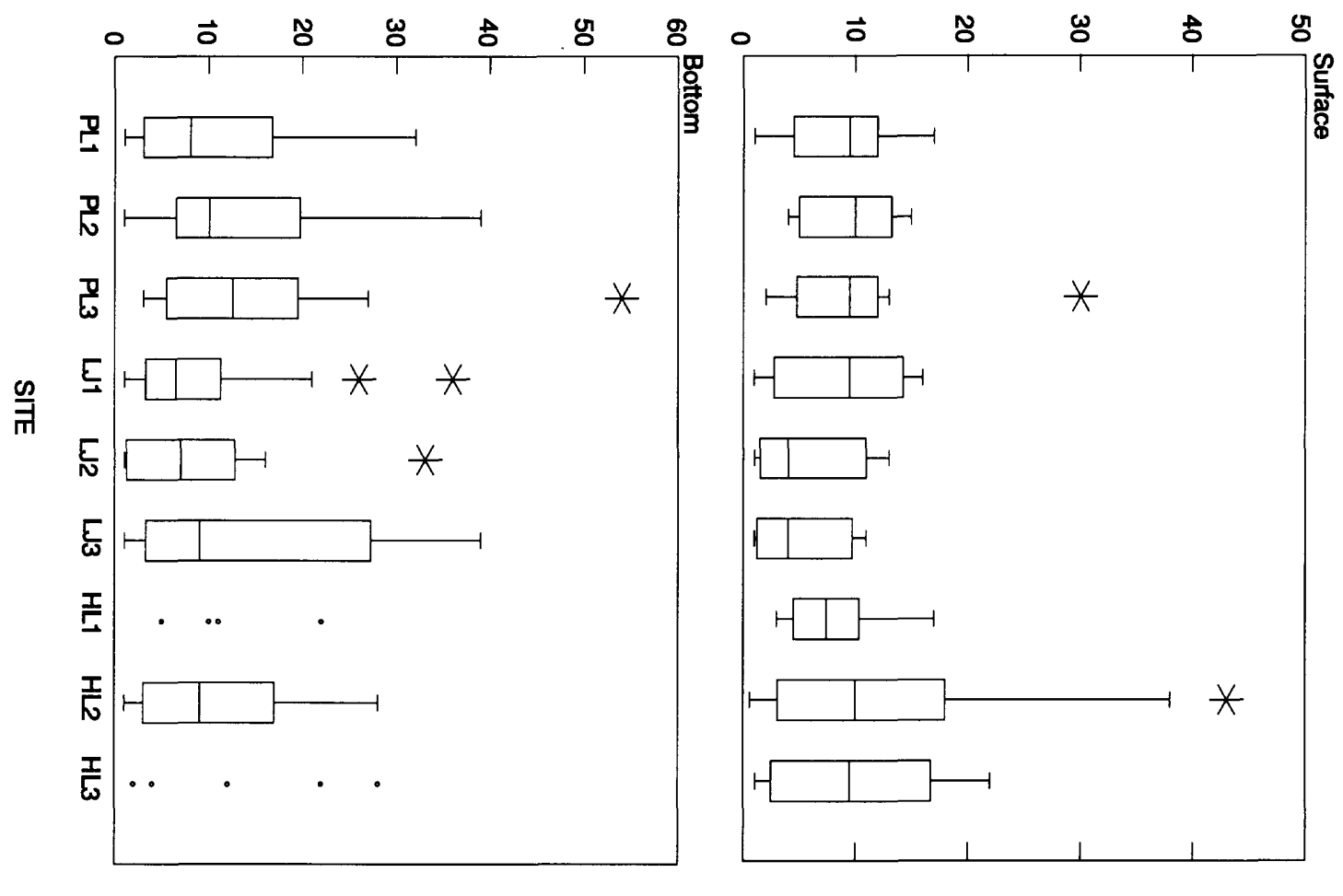

CHLOROPHYL a CONCENTRATION, IN MICROGRAMS PER UTER
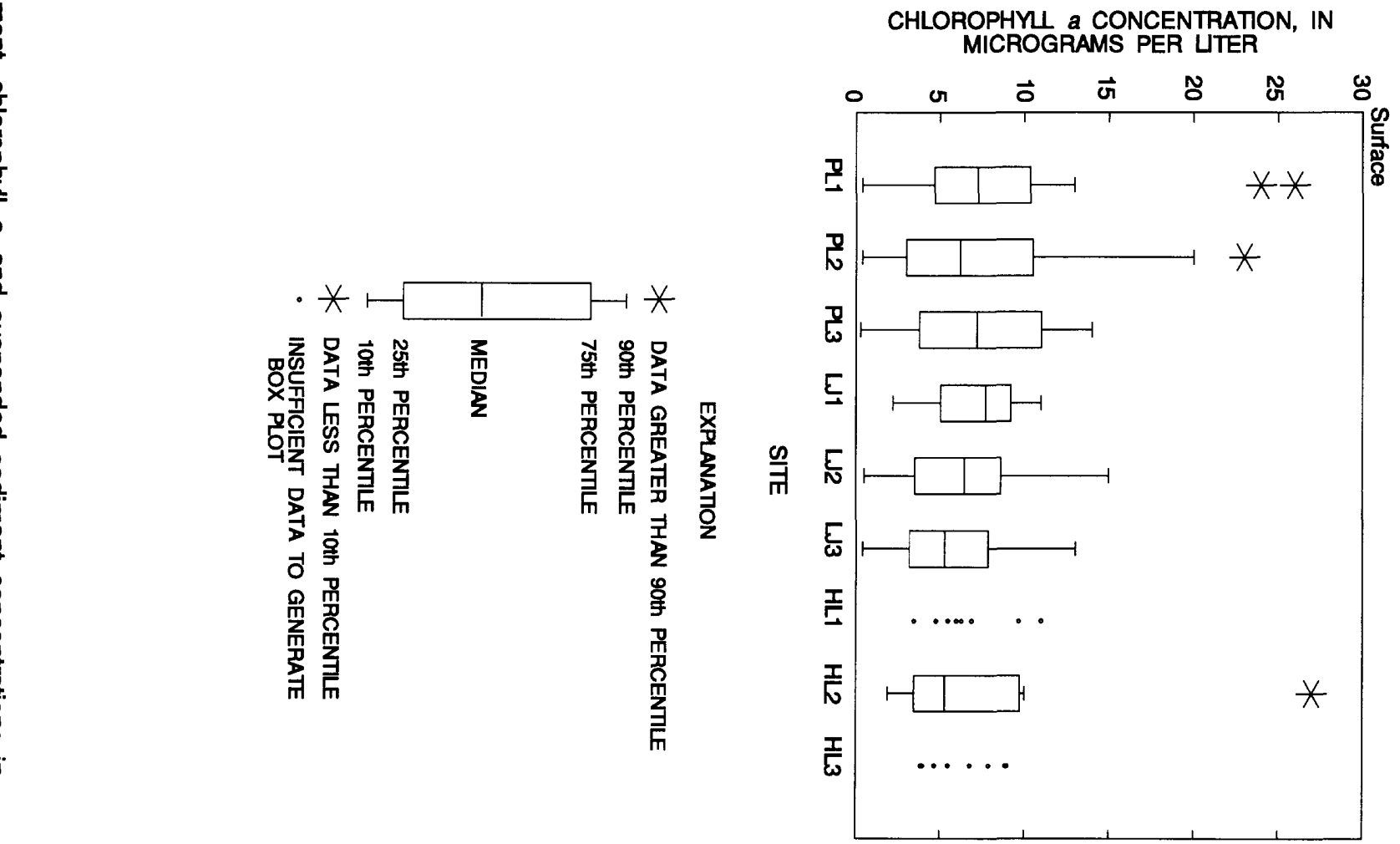
The maximum chlorophyll $a$ concentrations in the reservoirs were measured during June through October, corresponding to the period of maximum phytoplankton production. Minimum chlorophyll $a$ concentrations were measured in November through January during periods of lower phytoplankton production. The differences in median chlorophyll $a$ concentrations (fig. 7) between sites within an individual reservoir were not significant (Kruskal-Wallis test, $\alpha=$ 0.05).

Secchi depth values were correlated with total suspended solids concentrations, suspended sediment concentrations, and chlorophyll $a$ concentrations to determine which independent water-clarity characteristic had the greatest effect on Secchi depth in these reservoirs and the degree to which a relation existed. The correlation analyses were determined by using Spearman's rank order correlation coefficient $\left(\mathrm{r}_{\mathrm{s}}\right.$; Ott, 1993, p. 465-468). This correlation coefficient measures the monotonic association between $y$ and $x$; that is, it measures whether $y$ increases or decreases with $x$ regardless of whether the increase (or decrease) is linear or nonlinear. In each reservoir, the highest correlation existed between Secchi depth and suspended sediment concentrations, although the degree of correlation was weak. The $r_{s}$ value was $-0.46\left(r_{s}\right.$ ranges from -1 to +1 ) for Prairie Lee Lake data, -0.42 for Lake Jacomo data, and $\mathbf{- 0 . 1 2}$ for Harrisonville City Lake data.

\section{CHEMICAL CHARACTERISTICS}

The chemical characteristics of samples collected from the water columns of the three reservoirs are discussed in the following section. This is followed by a discussion of the chemical characteristics of reservoir inflow samples and bottom sediment samples.

\section{Reservoir Water Column}

The results of measurements and analyses of physical properties and chemical constituents from samples of the water columns of each of the three reservoirs are presented. These results are followed by a discussion of the trophic state of the reservoirs that was determined from selected water-clarity characteristics and chemical constituents of the water.

\section{Physical Propertles and Chemical Constituents}

The following section presents the summarized results for selected physical properties and chemical constituents from surface and bottom samples of the water columns of the three reservoirs. The KruskalWallis test was used to determine significant differences in the median values of many of the physical properties and chemical constituents in water samples from the three sampling sites within each reservoir. The results of the Kruskal-Wallis tests can be used to determine if there are significant differences in the spatial distribution of physical properties and chemical constituents in these reservoirs and can be used in determining optimum sampling procedures for future studies in these and similar reservoirs in Missouri. Statistical tests were not conducted on results from the Harrisonville City Lake bottom samples because there were not sufficient data at all sites.

\section{Specific Conductance}

Specific conductance is the measure of the ability of a solution to conduct electricity. As the ion concentration of a solution increases and the solution's ability to conduct electricity increases, the specific conductance of the solution increases. Therefore, specific conductance can be used as an indication of the ion concentration of a solution.

The median specific conductance values were higher for bottom samples than for surface samples at the same site (fig. 8; table 9, at the back of this report). This increase is most likely the result of differences in the release of dissolved material from the bottom sediments and is related to water depth and period of thermal stratification. The deeper sites have a longer period of thermal stratification and anoxic conditions, which favors the release of dissolved materials from the bottom sediments. The difference in median specific conductance values between surface samples within any individual reservoir was not statistically significant (Kruskal-Wallis test, $\alpha=0.05$ ), but there was a significant difference between median specific conductance values for bottom samples from Lake Jacomo.

\section{pH}

The $\mathrm{pH}$ value is a measurement of the hydrogen ion activity, and in most lakes and reservoirs it is regulated by the carbon dioxide-bicarbonate-carbonate $\left(\mathrm{CO}_{2}-\mathrm{HCO}_{3}-\mathrm{CO}_{3}\right)$ buffering system (Wetzel, 1983). 

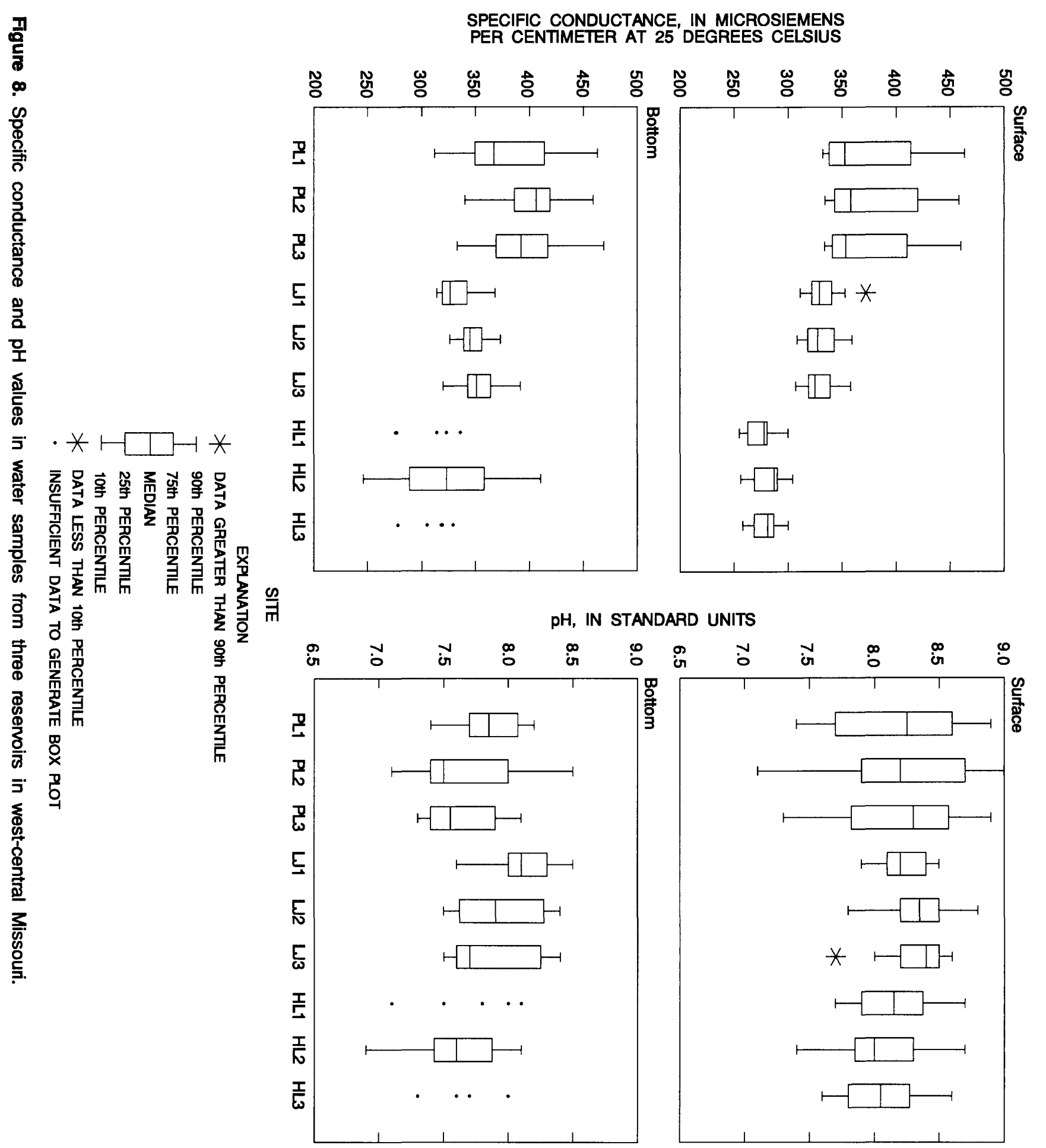
Biological processes such as photosynthesis and respiration can affect the concentration of dissolved $\mathrm{CO}_{2}$ in lakes and reservoirs and, therefore, affect the $\mathrm{pH}$ value. The $\mathrm{pH}$ in most lakes and reservoirs ranges from about 6 to 9 . The $\mathrm{pH}$ in surface and bottom samples from the three reservoirs was within this range (fig. 8; table 9). The surface samples from each reservoir had higher median $\mathrm{pH}$ values than bottom samples from the reservoir, which can be attributed, in part, to photosynthetic activity (lower $\mathrm{CO}_{2}$ concentration) in the surface waters. The difference in median $\mathrm{pH}$ values between surface or between bottom samples in an individual reservoir was not statistically significant (Kruskal-Wallis test, $\alpha=0.05$ ).

\section{Water Temperature}

Water temperature profile data were collected to determine the timing and degree of thermal stratification in the reservoirs. In the early spring, water temperatures in lakes and reservoirs in temperate zones are uniform throughout the water column, but as the air temperature increases, a thermal gradient develops between the warmer surface waters (epilimnion) and the cooler deeper waters (hypolimnion). The thermal gradient plane (thermocline) results in a resistant barrier to mixing of water between the epilimnion and the hypolimnion; the gradient layer between the two zones is termed the metalimnion. In shallow waters, thermal stratification continues until the warmer waters of the epilimnion extend to the lake bottom. In deeper waters, thermal stratification continues until fall when the water in the epilimnion cools and the thermocline degrades to the point where complete mixing occurs.

Thermal stratification also can occur in lakes and reservoirs in temperate zones during winter months. Water is most dense near $4^{\circ} \mathrm{C}$ (degrees Celsius). When a lake surface freezes, there can be 3 to 4 degrees difference in temperature between the ice on the surface and the bottom water. Winter stratification in the lower Midwestern States usually is short. Neither Prairie Lee Lake nor Lake Jacomo was covered with ice during the winter of 1991-92, but sections of Harrisonville City Lake were covered with ice between December 1992 and February 1993.

Water temperature varied substantially with depth and time as depicted at the deepest sites in the three study reservoirs (fig. 9). Temperatures ranged from $0{ }^{\circ} \mathrm{C}$ at Harrisonville City Lake during ice cover in January and February 1993 to about $27^{\circ} \mathrm{C}$, which was measured at each reservoir during July. All three reservoirs displayed typical thermal depth profiles for reservoirs of this size in the lower Midwestern States because thermal stratification conditions were present from May through late September or early October at the deepest sites.

\section{Dissolved Oxygen}

Dissolved oxygen is a critical requirement in the metabolic processes of aerobic aquatic organisms, and the distribution of dissolved oxygen in a lake or reservoir will greatly determine the distribution of these organisms. During thermal stratification, the hypolimnion is physically isolated from atmospheric and biological reaeration processes. In productive lakes or reservoirs, dissolved oxygen concentrations are substantially decreased in the hypolimnion by chemical reduction and biological respiration reactions. Dissolved oxygen concentrations varied substantially with depth and time in the three study reservoirs (fig. 9) and ranged from about $0.1 \mathrm{mg} / \mathrm{L}$ (milligram per liter) in the hypolimnion of each reservoir during thermal stratification to about $10 \mathrm{mg} / \mathrm{L}$ throughout the water column in winter. Anoxic conditions were present in the hypolimnion of Prairie Lee Lake for approximately 90 days at the shallowest bottom site (PL1) and about 150 days at the deepest site (PL2). In Lake Jacomo, anoxic conditions in the hypolimnion ranged from 30 days at the shallowest bottom site (LJ1) to about 140 days at the deepest site (LJ3). Similarly, in Harrisonville City Lake, anoxic conditions were present for about 90 days at HL1 and 150 days at the deepest bottom site (HL2).

\section{Alkalinity}

The alkalinity of a solution is a measure of the capacity of the solutes in the solution to neutralize acids (Hem, 1985). The greater the alkalinity of a solution, the greater its acid-neutralizing capacity. In most lakes and reservoirs, alkalinity is produced by two dissolved $\mathrm{CO}_{2}$ species, $\mathrm{HCO}_{3}$ and $\mathrm{CO}_{3}$. The alkalinity of the bottom samples was higher than the alkalinity in the surface samples (fig. 10; table 9). This increase could be explained by the addition of dissolved $\mathrm{CO}_{2}$ species in the bottom waters as products of decomposition and by the dissolution of calcium carbonate $\left(\mathrm{CaCO}_{3}\right)$ from the bottom sediments (Wetzel, 1983). Although there were no significant differences in median alkalinity between surface samples within an individual reservoir, there were significant differences in median alkalinity between bottom samples within 
Prairie Lee Lake and bottom samples within Lake Jacomo (Kruskal-Wallis test, $\alpha=0.05$ ). These differences are likely caused by the variable effects of thermal stratification and periods of anoxic conditions in these reservoirs.

\section{Nitrogen}

Nitrogen is an important element in biological processes and occurs in both inorganic and organic forms in lakes and reservoirs. The most abundant form of $\mathrm{N}$ in surface and bottom water samples in all three reservoirs typically was total organic $\mathrm{N}$ (fig. 11; table 9). Organic $N$ is that form present in living and dead plant and animal tissue. Concentrations of total organic $\mathrm{N}$ are closely related to changes in the phytoplankton and zooplankton populations. The maximum total organic $\mathrm{N}$ concentration measured in the surface samples from Prairie Lee Lake was $1.4 \mathrm{mg} / \mathrm{L}$ at site PL3 on June 6 and June 26, 1991; from Lake Jacomo, $1.1 \mathrm{mg} / \mathrm{L}$ at site $\mathrm{LJ} 2$ on June 25,1991 ; and from Harrisonville City Lake, $1.1 \mathrm{mg} / \mathrm{L}$ at site HL2 on May 19, 1992. These sample dates correspond to the periods in which some of the largest phytoplankton counts and biomass were measured in the surface waters of these reservoirs. Phytoplankton and zooplankton population dynamics are factors affecting the range in distribution of total organic $\mathrm{N}$ at a particular site in a reservoir, but median total organic $\mathrm{N}$ concentrations for surface and bottom samples were not significantly different from one site to another within an individual reservoir (Kruskal-Wallis test, $\alpha=0.05$ ).

The median concentrations of total ammonia $\left(\mathrm{NH}_{3}+\mathrm{NH}_{4}{ }^{+1}\right.$, hereafter referred to as $\left.\mathrm{NH}_{3}\right)$ as $\mathrm{N}$ for surface samples from the three reservoirs were about an order of magnitude less than median total organic $\mathrm{N}$ concentrations for these samples (fig. 11; table 9). There were no significant differences between median concentrations of $\mathrm{NH}_{3}$ for surface-water samples in any individual reservoir (Kruskal-Wallis test, $\alpha=$ 0.05 ). The median concentrations of $\mathrm{NH}_{3}$ for bottom samples also were typically less than median total organic $\mathrm{N}$ concentrations at all sites; however, the range in $\mathrm{NH}_{3}$ concentrations for bottom samples was larger than that of total organic $\mathrm{N}$ concentrations (fig. 11; table 9). The maximum $\mathrm{NH}_{3}$ concentrations for bottom samples at all reservoir sites were measured from samples collected during thermal stratification. Factors that may account for the relatively higher concentrations of $\mathrm{NH}_{3}$ in the bottom samples than concentrations for surface samples at a site include: (1) settling organic material that decomposes and releases $\mathrm{NH}_{3}$; (2) bacterial nitrification [conversion of $\mathrm{NH}_{3}$ to nitrate $\left(\mathrm{NO}_{3}\right)$ and nitrite $\left(\mathrm{NO}_{2}\right)$ ] that is not taking place in the anoxic hypolimnion as it is in the aerobic epilimnion; and (3) the release of $\mathrm{NH}_{3}$ from bottom sediments under anoxic conditions (Wetzel, 1983). There were significant differences in median $\mathrm{NH}_{3}$ concentrations for bottom samples from the three sites within Prairie Lee Lake and in samples from the three bottom sites within Lake Jacomo. This difference can most likely be explained by the variation in the period of anoxic conditions in the hypolimnion, which ranged from 30 to 150 days in these reservoirs depending on sampling depth, and the variation in the corresponding period of $\mathrm{NH}_{3}$ releases from the bottom sediments.

The total $\mathrm{NO}_{3}$ as $\mathrm{N}$ concentrations for surface and bottom samples from Prairie Lee Lake and Harrisonville City Lake were similar to, but somewhat less than, total organic $\mathrm{N}$ concentrations for these reservoirs. Concentrations of total $\mathrm{NO}_{3}$ for both surface and bottom samples from Lake Jacomo were less than total organic $\mathrm{N}$ and $\mathrm{NH}_{3}$ concentrations for this reservoir. There were no statistically significant differences in the median $\mathrm{NO}_{3}$ concentrations between surface or bottom samples within a reservoir (Kruskal-Wallis test, $\alpha=0.05$ ). Total $\mathrm{NO}_{3}$ concentrations for surface and bottom samples from Lake Jacomo did not exceed $0.19 \mathrm{mg} / \mathrm{L}$ during the sampling period, but maximum $\mathrm{NO}_{3}$ concentrations for Prairie Lee Lake, immediately upstream from Lake Jacomo, were near $1 \mathrm{mg} / \mathrm{L}$ for both surface and bottom samples. The most probable explanation for the low concentrations of $\mathrm{NO}_{3}$ for Lake Jacomo relative to those for Prairie Lee Lake is that $\mathrm{NO}_{3}$ loads are less for Lake Jacomo inflows than loads for Prairie Lee Lake inflows. The $\mathrm{NO}_{3}$ entering Prairie Lee Lake from inflows is "trapped" and is not transported into Lake Jacomo (see "Reservoir Inflow" section), and $\mathrm{NO}_{3}$ loads are low from the relatively undisturbed local Lake Jacomo Basin.

\section{Phosphorus}

Phosphorus is the nutrient that limits biological activity in most lakes and reservoirs (Hutchinson, 1957). An increased availability of $P$ in such water bodies can quickly lead to increased phytoplankton production. The range in total $\mathrm{P}$ and total orthophosphate $\left(\mathrm{PO}_{4}\right)$ as $\mathrm{P}$ concentrations in the bottom water samples from the three reservoirs exceeded the range in the surface water samples from these reservoirs (fig. 12; table 9). This range, as in similar ranges for other 


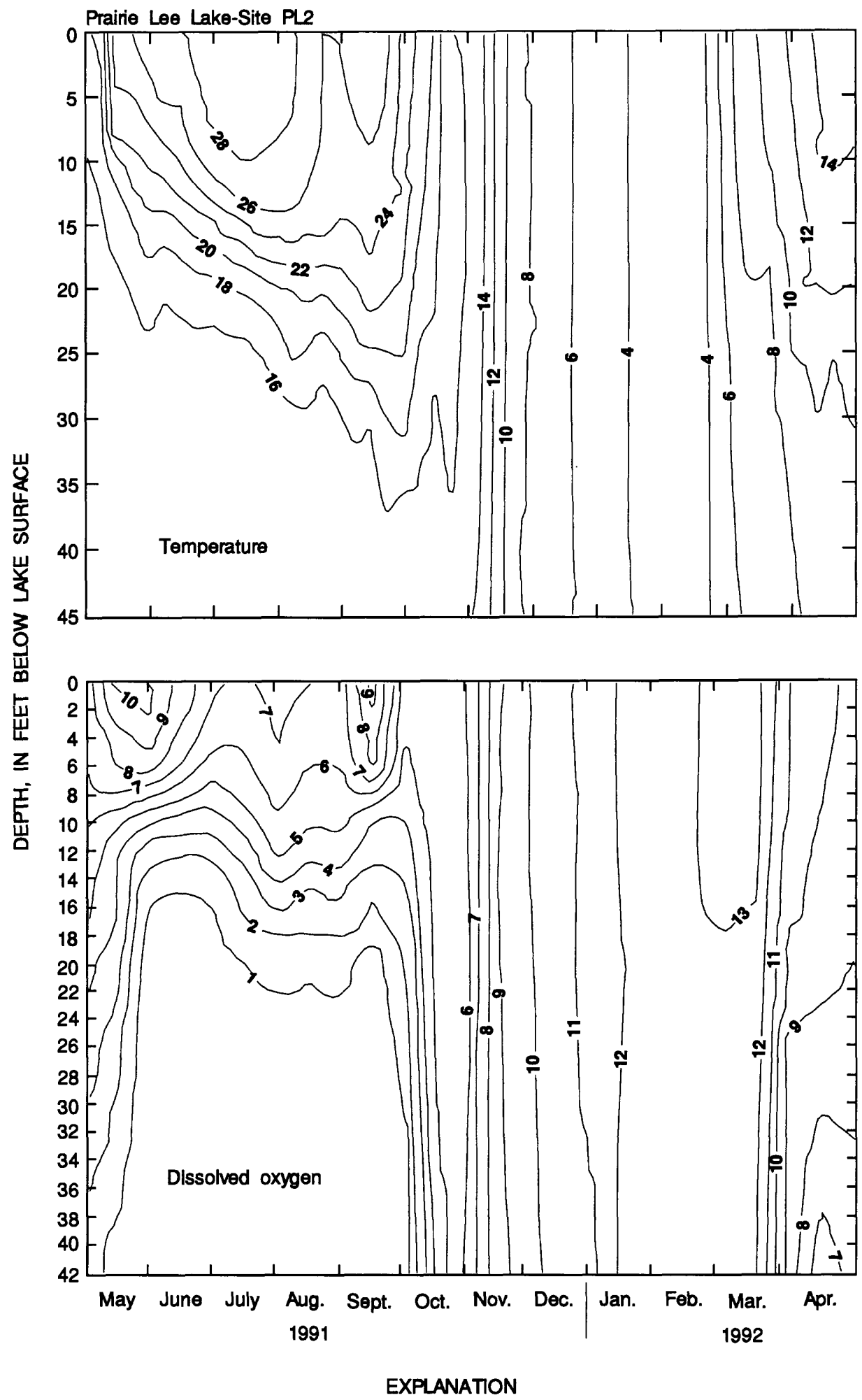

- 10 - LINE OF EQUAL TEMPERATURE AND DISSOLVED OXYGEN CONCENTRATION--Interval is variable. Temperature is in degrees Celsius and Dissolved oxygen is in milligrams per liter

Figure 9. Depth-time distribution of water temperature and dissolved oxygen in three reservoirs in west-central Missouri. 


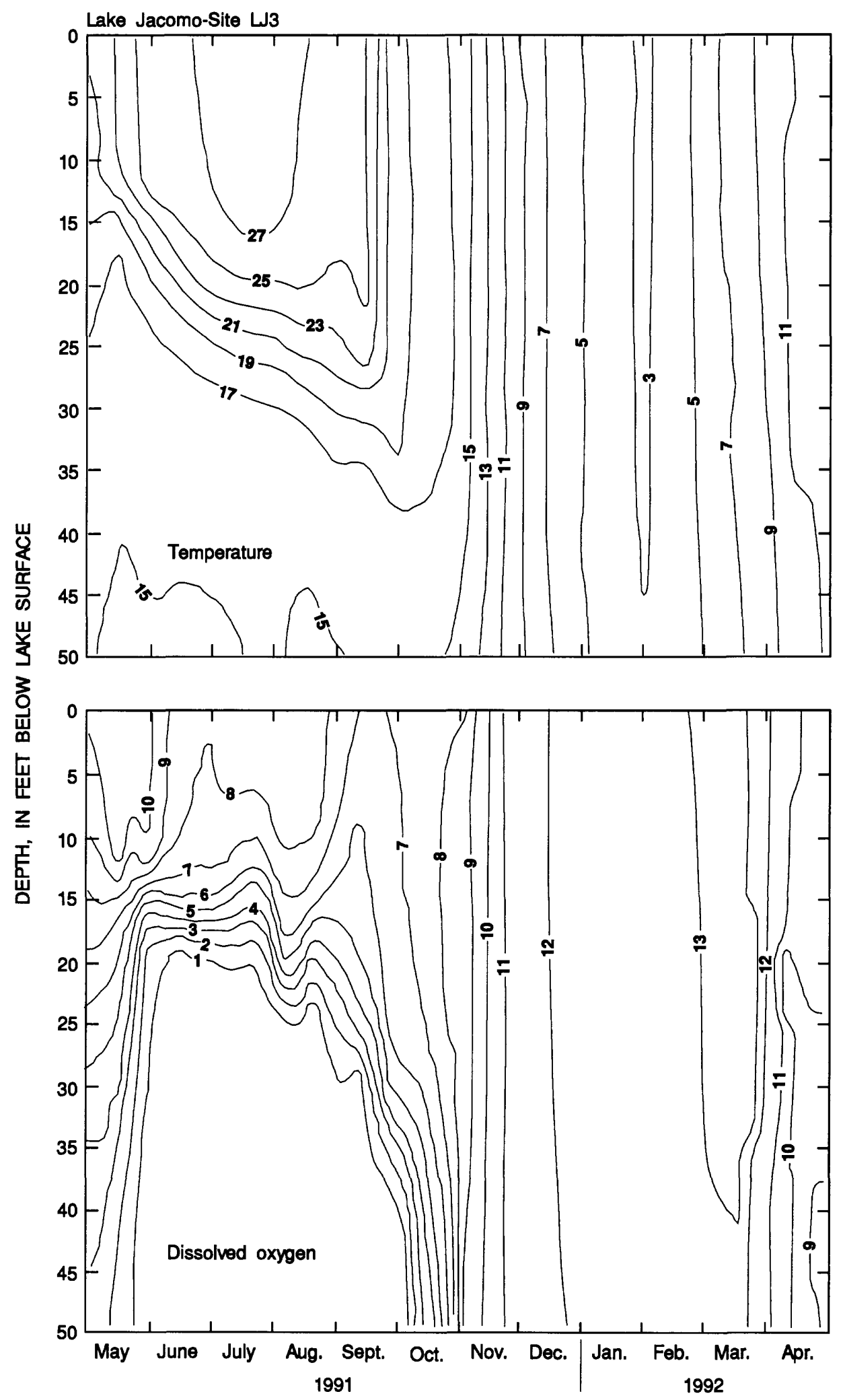

Figure 9. Depth-time distribution of water temperature and dissolved oxygen in three reservoirs in west-central Missouri--Continued. 


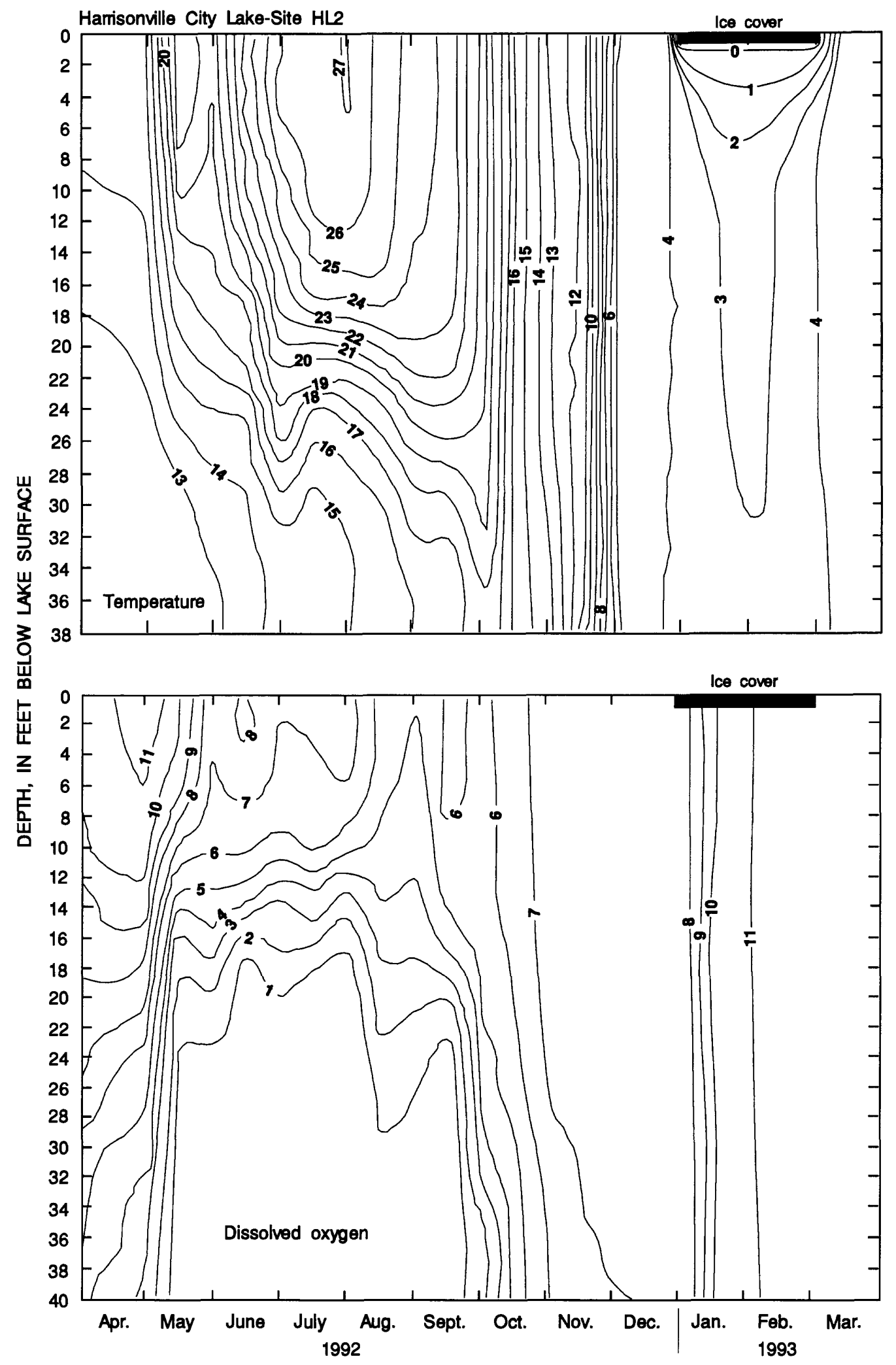

Figure 9. Depth-time distribution of water temperature and dissolved oxygen in three reservoirs in west-central Missouri--Continued. 


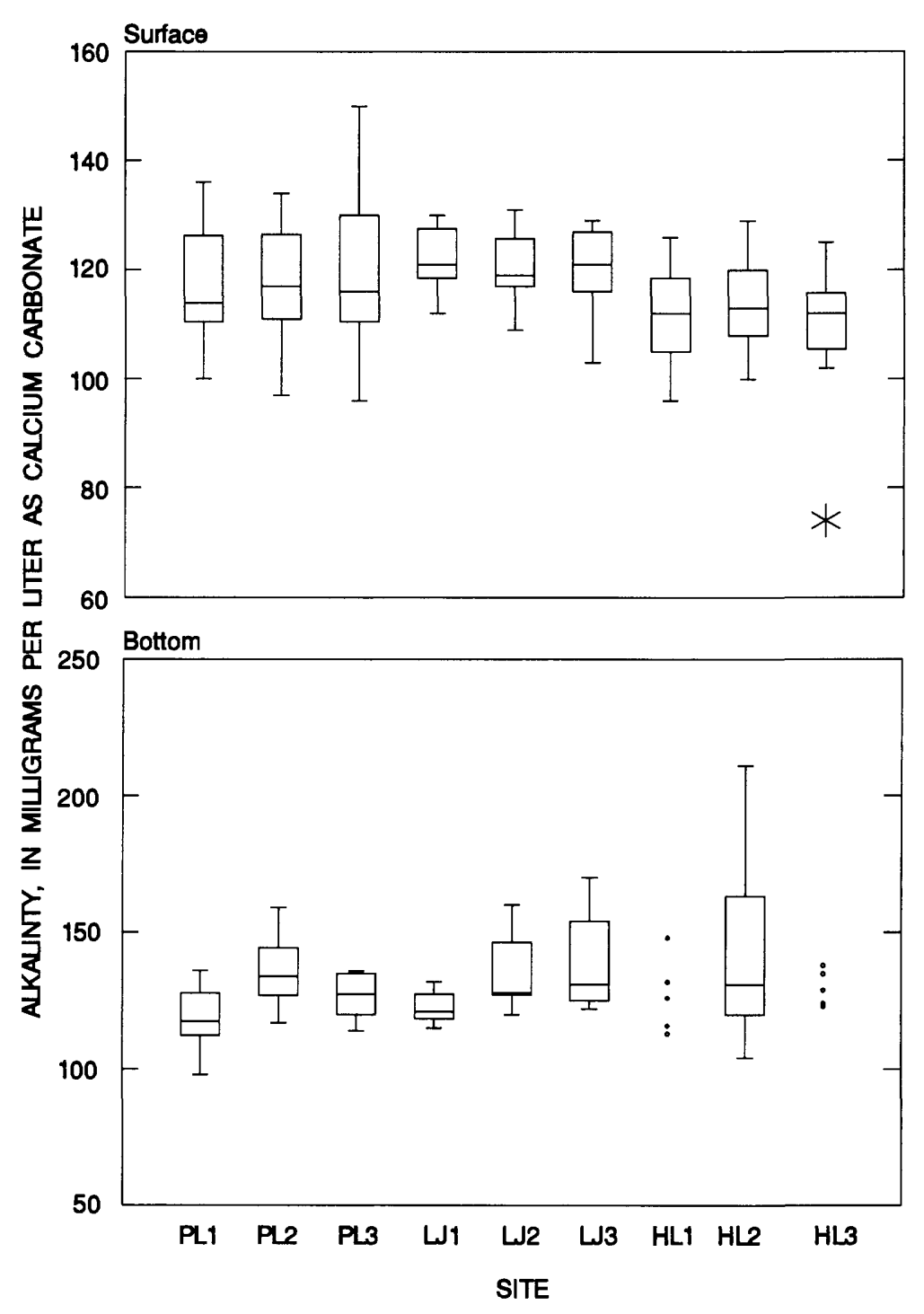

EXPLANATION

* data greater than 90th percentile

T 90th PERCENTILE

75th PERCENTILE

MEDIAN

25th PERCENTILE

$\perp$ 10th PERCENTLE

* Data less than 10th PERCENTIL - insuFficient data to generate

Figure 10. Akalinity in water samples from three reservoirs in west-central Missouri. 

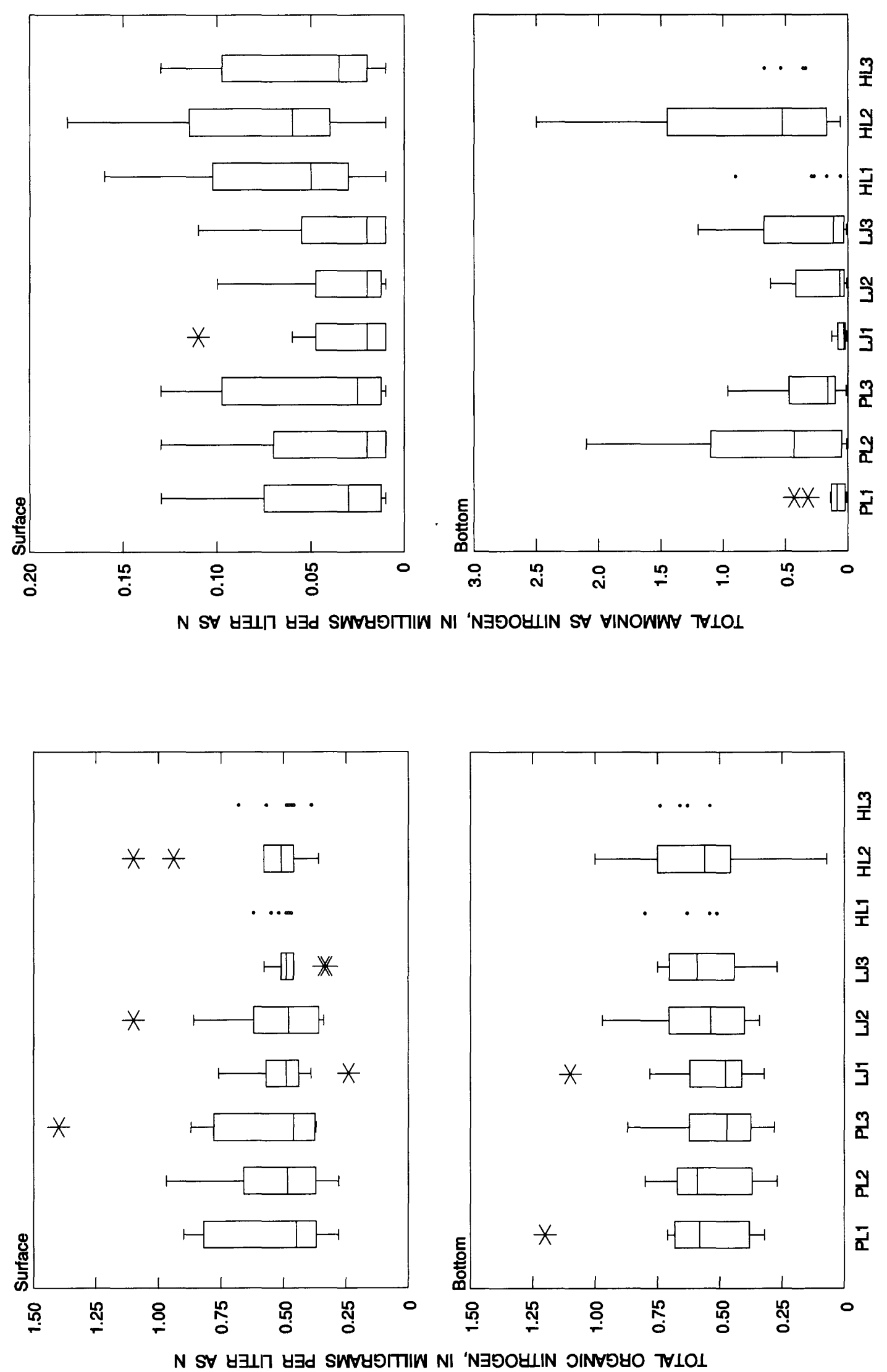

$\frac{\Perp}{\text { ๘ }}$ 


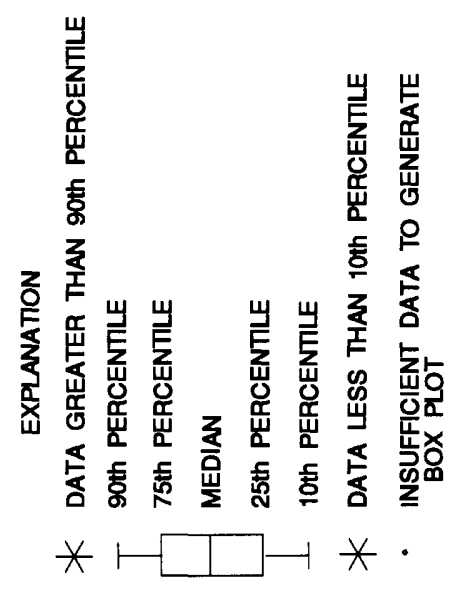

NJפOHIIN S 

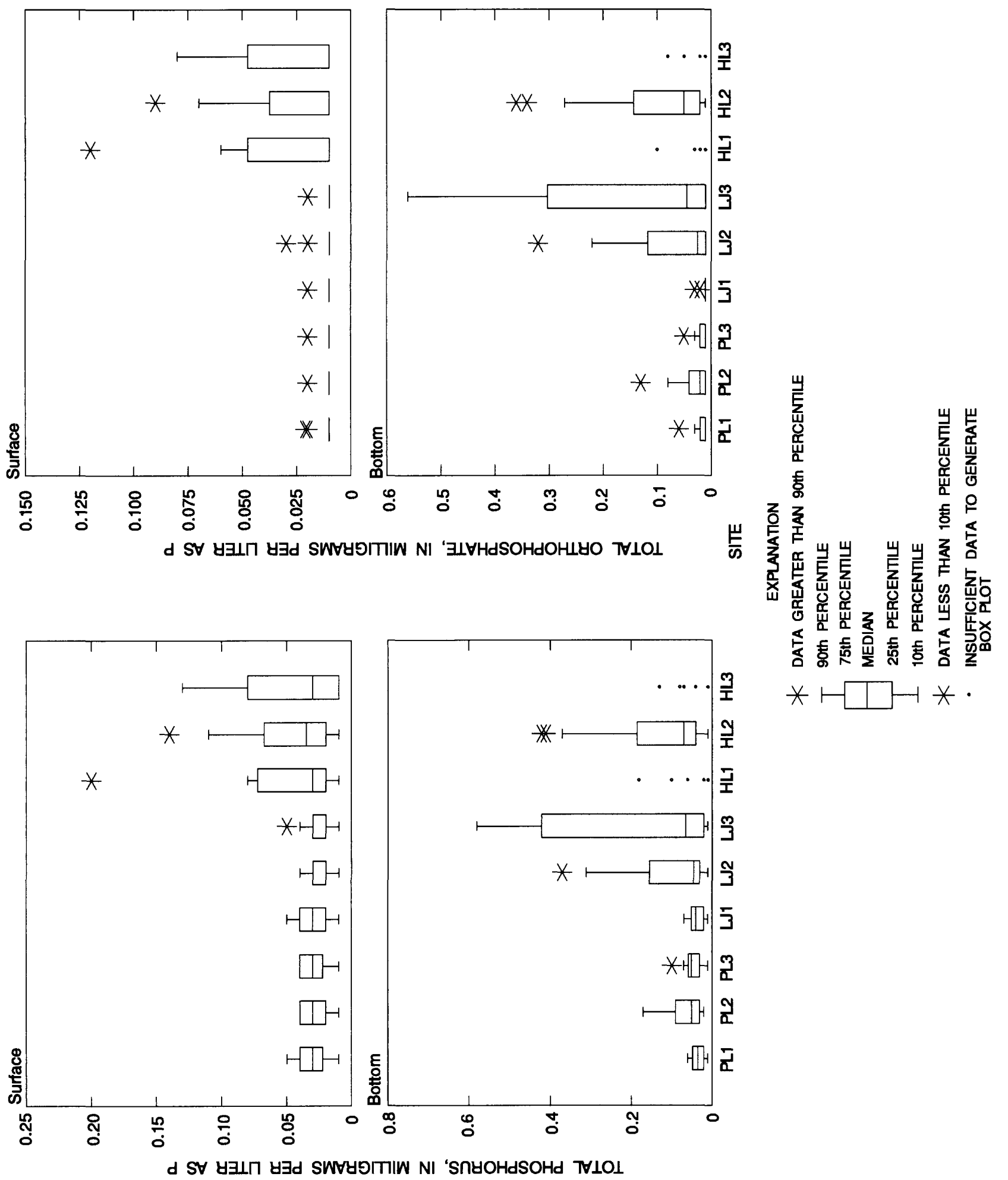
physical properties and chemical constituents, can be attributed to effects of thermal stratification and anoxic conditions in the hypolimnion.

Several studies have shown that $P$ is released from the bottom sediments into the hypolimnion during anoxic conditions (Mortimer, 1941, 1942; Cooke and others, 1977; Theis and McCabe, 1978; Larsen and others, 1981; Nurnberg and Peters, 1984; Field and Duerk, 1988), although the release of $P$ can occur under aerobic conditions as well (Hutchinson, 1957; Holdren and Armstrong, 1980). There may be as much as a one-thousand fold increase in the release rate of $P$ under anoxic conditions in comparison to the release rate under aerobic conditions (Wetzel, 1983). During thermal stratification, the thermocline provides a physical barrier between the mixing of the P-rich hypolimnion and the P-deficient epilimnion, although $P$ may "leak" through the metalimnion by wind action, vertical entrainment, and diffusion (Stauffer and Lee, 1973; Mortimer, 1974; Larsen and others, 1981; Kortmann and others, 1982). During the fall, when thermal stratification degrades and aerobic conditions develop, much of the available P may combine with ferric iron $\left(\mathrm{Fe}^{+3}\right)$ to form ferric phosphate or may be absorbed onto ferric hydroxide and $\mathrm{CaCO}_{3}$ and precipitate from the water column.

The maximum concentrations of total $\mathrm{P}_{\text {and }} \mathrm{PO}_{4}$ in bottom samples from all the reservoirs occurred during periods of anoxic conditions in the hypolimnion. The maximum concentration of total $\mathrm{P}$ and $\mathrm{PO}_{4}$ for surface samples of Prairie Lee Lake and Lake Jacomo occurred following degradation of the thermocline and subsequent mixing of the hypolimnion and epilimnion. In Harrisonville City Lake the maximum concentrations of total $\mathrm{P}$ and $\mathrm{PO}_{4}$ for surface samples occurred on the January 27 and the February 24, 1993, sampling dates. On these dates ice covered much of the main body of the lake, and water samples were collected from shore. The elevated total $\mathrm{P}$ and $\mathrm{PO}_{4}$ concentrations were likely because of activity of geese in open waters near shore. When comparing median total $\mathrm{P}$ and $\mathrm{PO}_{4}$ concentrations for surface and bottom samples within a reservoir, the only significant difference (Kruskal-Wallis test, $\alpha=0.05$ ) was detected in median $\mathrm{PO}_{4}$ concentrations for bottom samples from the three Lake Jacomo sites.

The total $\mathrm{N}$ to total $\mathrm{P}$ ratio (TN:TP) commonly is used as an indicator of whether $\mathrm{N}$ or $\mathrm{P}$ is limiting phytoplankton production in a lake or reservoir. The TN:TP ratio in algal cells is about $15: 1$. A TN:TP ratio greater than 20 is used as an indicator that $P$ is limiting phytoplankton production, whereas a TN:TP ratio of less than 10 is an indicator that $\mathrm{N}$ is limiting phytoplankton production. A TN:TP of between 10 and 20 indicates transition conditions. The TN:TP ratio from Prairie Lee Lake surface samples remained greater than 20 throughout the sampling period. There were periods in the fall and winter months in which the average TN:TP ratio in surface samples from Lake Jacomo and Harrisonville City Lake was in transition conditions. The transition period corresponded with the degradation of the thermocline and mixing of the P-rich hypolimnion with the epilimnion, which increased $P$ concentrations in the epilimnion and decreased TN:TP ratios. Additional bioassay analyses would be needed to determine which nutrient is limiting phytoplankton production during this period. In Harrisonville City Lake, the low TN:TP ratios in September through February can be attributed to mixing of the P-rich hypolimnion with the epilimnion as the thermocline degraded and to the higher P concentrations in the January 27 and February 24, 1993, near shore samples collected during ice cover on the reservoir.

\section{Pesticides}

Twenty pesticides were analyzed in surface and bottom samples collected from Harrisonville City Lake between April 1992 and March 1993 (table 10, at the back of this report). Nine pesticides were detected in the samples, including (listed in decreasing frequency of detection) atrazine, desethylatrazine, deisopropylatrazine, metolachlor, ametryn, propazine, alachlor, 2,4-D, and cyanazine.

Atrazine, a pre-emergence and post-emergence herbicide used for control of some annual grasses and broadleaf weeds in corn, fallow land, sorghum, fruit crops, and lawns (Montgomery, 1993), was detected in all surface and bottom samples collected from the reservoir. Concentrations ranged from $0.55 \mu \mathrm{g} / \mathrm{L}$ (microgram per liter) at site HL3 for the surface sample on January 27,1993 , to $4.67 \mu \mathrm{g} / \mathrm{L}$ at site HL2 for the bottom sample on May 19, 1992. Atrazine concentrations exceeded the maximum contaminant level (MCL) of 3 $\mu \mathrm{g} / \mathrm{L}$ for drinking water (U.S. Environmental Protection Agency, 1992) for all surface and bottom samples collected between late April and early November 1992. The $3 \mu \mathrm{g} / \mathrm{L} \mathrm{MCL}$ for atrazine for drinking water is based on the mean concentration of at least four quarterly samples. The concentration of atrazine did 
not exceed the MCL for any sample collected in the reservoir between December 1992 and March 1993. The mean concentration $(2.8 \mu \mathrm{g} / \mathrm{L})$ of all surface samples collected from April 1992 to March 1993 was less than the MCL, although concentrations of 26 of the 36 surface samples (excluding duplicates and replicates) exceeded the MCL. Site HL2 was the only site for which bottom samples were collected throughout the entire 12-month period. The mean atrazine concentration in 11 bottom samples from this site was $3.3 \mu \mathrm{g} / \mathrm{L}$, and concentrations for 8 of 11 samples exceeded the MCL.

Atrazine primarily is applied to crops in the spring, and the greatest potential for transport of atrazine into surface waters is during stormwater runoff immediately following application (Thurman and others, 1991). Once atrazine has been transported into a lake or reservoir during a spring or early summer runoff, it is likely to remain in the system until it degrades or there is a sufficient amount of inflow to "flush" the reservoir contents. At site HL2 in Harrisonville City Lake where atrazine concentrations exceeded the MCL from late April to early November 1992 (fig. 13), there were no large discharges from the reservoir outflow structures during this period based on reservoir stages. There was not a substantial decrease in atrazine concentrations during the late April-early November retention period, and the concentration of the atrazine degradation products desethylatrazine and deisopropylatrazine remained relatively unchanged.

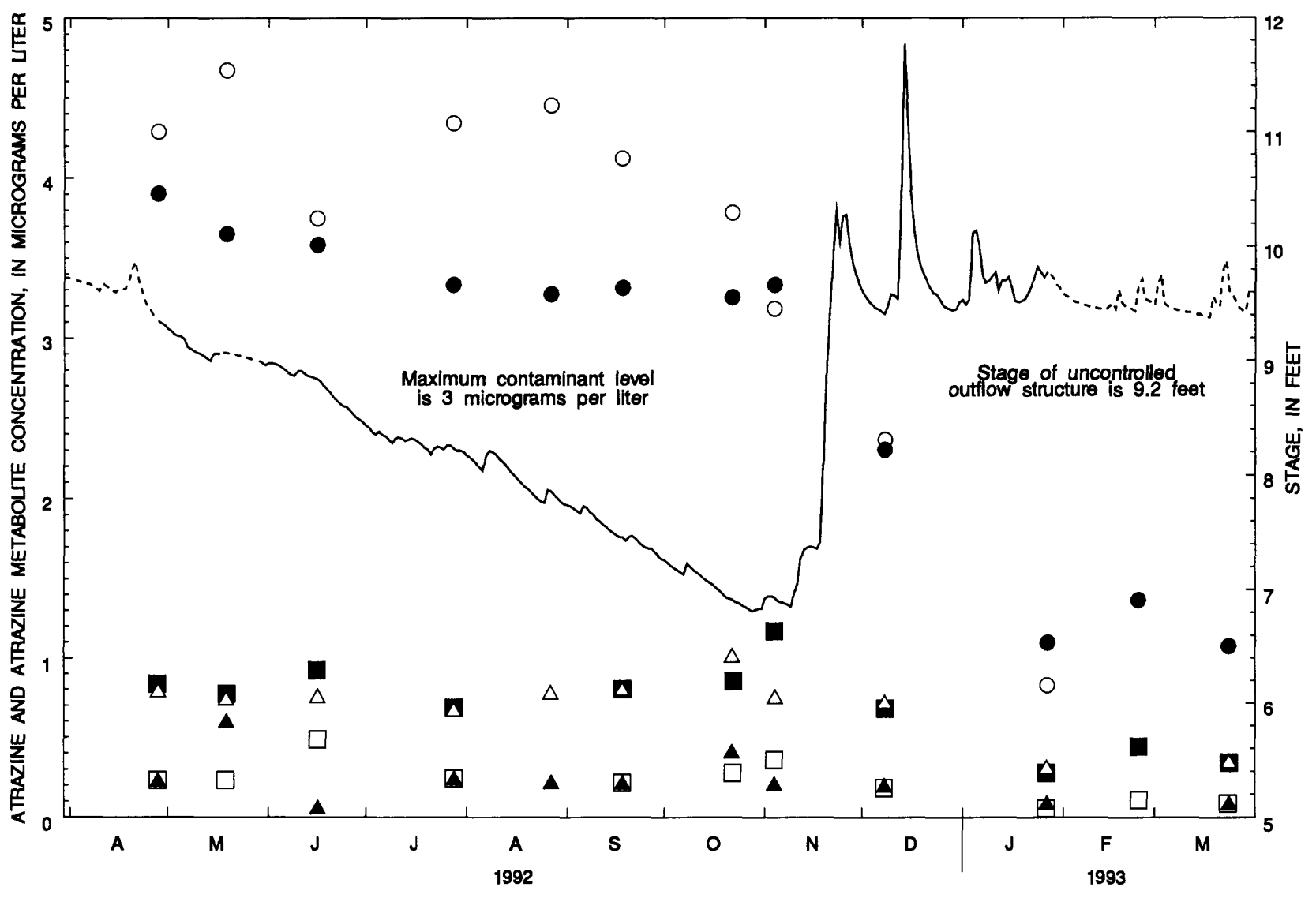

EXPLANATION

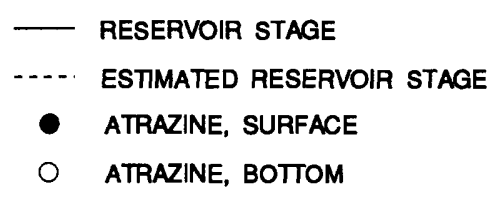
- DESETHYLATRAZINE, SURFACE
$\triangle$ DESETHYLATRAZINE, BOTTOM
$\square$ DEISOPROPMLATRAZINE, SURFACE
A DEISOPROPYATRAZINE, BOTTOM

Figure 13. Temporal distribution of atrazine and atrazine metabolites and reservoir stage, Harrisonville City Lake, west-central Missouri, site HL2. 
The reservoir stage increased beginning in midNovember, and by late November the water level in the reservoir exceeded the outflow structures. There was a substantial decrease in atrazine concentrations in the December 8,1992, samples, which were the first water samples collected following the beginning of reservoir outflows. It seems that the reservoir contents were "flushed" during November and December 1992 as inflows into the reservoir were about 6,600 acre-ft, which is equivalent to about 95 percent of the volume of the reservoir. By January 27, 1993, the atrazine concentrations in surface and bottom samples decreased to about $1 \mu \mathrm{g} / \mathrm{L}$.

The concentration of atrazine in the surface samples at site HL2 remained lower than concentrations in the bottom samples collected between April and October 1992 (fig. 13). A statistical comparison of the median atrazine concentration for the surface and bottom samples collected at site HL2 during this period indicates there was a significant difference between atrazine concentrations in the surface and bottom samples (Mann-Whitney test, $\alpha=0.05$ ). Possible explanations for this difference include: (1) photodegradation and volatilization of atrazine at the surface waters of the reservoir; (2) the pre-thermal stratification inflows would tend to have a higher concentration of atrazine and would be cooler and more dense than later inflows, which may contain a lower concentration of atrazine and be warmer and have a tendency to remain above the thermocline; and (3) adsorption of atrazine onto particulate organic matter in the surface water, which subsequently settled out into the bottom waters of the reservoir.

Maximum concentrations of eight other pesticides detected in water samples from Harrisonville City Lake did not exceed established health-based limits. Desethylatrazine was detected in all surface and bottom samples. A maximum concentration of 1.1 $\mu \mathrm{g} / \mathrm{L}$ was detected at site HL2 at the surface on November 4, 1992. Metolachlor, a pre-emergence herbicide used to control most annual grasses and many annual weeds in corn, milo, and soybeans (Montgomery, 1993), also was detected in all surface and bottom samples; the maximum concentration detected was $1.48 \mu \mathrm{g} / \mathrm{L}$ in a bottom sample from site HL2 on April 28,1992 . Deisopropylatrazine was detected in 61 of 62 water samples, and the maximum concentration detected was $0.59 \mu \mathrm{g} / \mathrm{L}$ in a bottom sample from site HL2 on May 19, 1992. Ametryn, a herbicide used to control broadleaf and grass weeds in corn, was detected in 32 of 62 samples, and the maximum concentration of $0.08 \mu \mathrm{g} / \mathrm{L}$ was detected in a bottom sample from site HL2 on September 18 and October 22, 1992. Propazine, a selective pre-emergence herbicide used to control annual grasses and broadleaf weeds in milo and sweet sorghum, was detected in 11 of 62 water samples, and the maximum concentration detected was $0.21 \mu \mathrm{g} / \mathrm{L}$ in a bottom sample at site HL2 on April 28, 1992. Alachlor, a pre-emergence, early post-emergence, or soil-incorporated herbicide used to control most annual grasses and many annual broadleaf weeds in corn, milo, soybeans, and certain woody ornamentals, was detected in 2 of 62 samples, at a concentration of $0.09 \mu \mathrm{g} / \mathrm{L}$ in a surface and a bottom sample at site HL1 on September 18, 1992. The herbicide 2,4-D, which is used for post-emergence control of annual and perennial broadleaf weeds in fruits, vegetables, turfs, and ornamental plants, was detected in 2 of 15 samples, at a maximum concentration of 0.35 $\mu \mathrm{g} / \mathrm{L}$ in a surface sample from site HL3 on March 24, 1993. Cyanazine, a herbicide used in the control of annual grasses and broadleaf weeds in cereals and soybeans, was detected in 1 of 62 samples, at a concentration of $0.13 \mu \mathrm{g} / \mathrm{L}$ in a bottom sample from site HL2 on June 16, 1992.

\section{Trophlc State}

One method of classifying the productivity of lakes and reservoirs is through the Trophic-State Index (TSI) described in a report by Carlson (1977). The Secchi depth [TSI(SD)], chlorophyll concentration [TSI(CHL)], and total P concentration [TSI(TP)] are used as factors to calculate trophic-state indices. Indices are scaled from 0 to 100 and each major division (of 10) represents a doubling in algal biomass. Indices less than 40 indicate more oligotrophic conditions, greater than 50 indicate more eutrophic conditions, and between 40 and 50 indicate mesotrophic conditions (Reckhow, 1979). The results for the three reservoirs vary by factors [TSI(SD), TSI(CHL), and TSI(TP)] and with time (fig. 14). One factor from each reservoir consistently was in the mesotrophic range, including TSI(TP) at Prairie Lee Lake and Lake Jacomo and TSI(CHL) at Harrisonville City Lake. The TSI(CHL) and TSI(TP) during summer months may be better indicators of the trophic state in these reservoirs because the Secchi depth in reservoirs in the Osage Plains physiographic province of Missouri can be more a function of total suspended solids than of phytoplankton effects (Jones and Knowlton, 1993). 

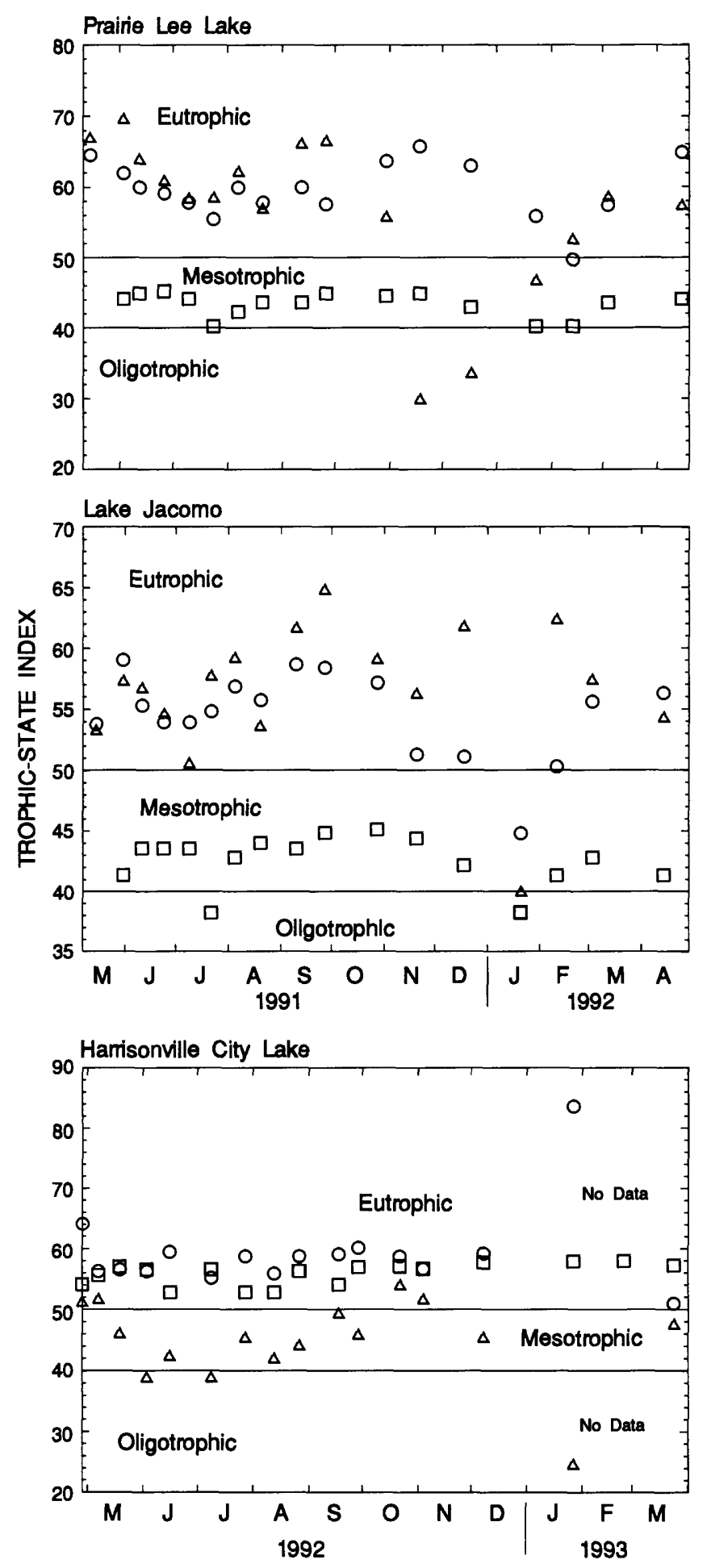

\section{EXPLANATION \\ O SECCHI DISK DEPTH \\ $\triangle$ CHLOROPHYL \\ $\square$ TOTAL PHOSPHORUS}

Figure 14. Mean surface Trophic-State Index values for three reservoirs in west-central Missouri.
All three reservoirs would be classified as mesotrophic to eutrophic.

A trophic state classification system was developed for lakes and reservoirs in Missouri by Jones and Knowlton (1993) based on ranges in chlorophyll $a$, total $\mathrm{N}$ (Kjeldahl and $\mathrm{NO}_{3}$ ), and total $\mathrm{P}$ concentrations (table 11). Using this classification system and the data (median concentration in surface samples) collected from the current study, Prairie Lee Lake can be classified as eutrophic, and Lake Jacomo and Harrisonville City Lake can be classified as mesotrophic to eutrophic (table 12).

\section{Reservoir Inflow}

Water-quality monitoring sites were established upstream from Prairie Lee Lake and Harrisonville City Lake (table 2; figs. 2 and 3) to determine sources and relative contributions of suspended solids, nutrients, and sediment. Samples for pesticide concentrations also were collected in base flow and stormwater runoff from the Harrisonville City Lake inflow sites. The results of these analyses are discussed in the following sections.

\section{Selected Constituent Loads}

The mass and mass per acre loads of selected constituents, including total suspended solids, $\mathrm{NH}_{3}$, $\mathrm{NO}_{3}$, and $\mathrm{TP}$, were determined for the three inflow basins into Prairie Lee Lake (sites PI1, PI2, and PI3), the single major inflow into Lake Jacomo (site PL4), and for the three major inflow basins into Harrisonville City Lake (sites HI1, HI2, and HI3; figs. 15 through 17). These data provide insight into the relative contributions of these constituents from each basin for selected storms.

No consistent relation is evident between storm precipitation and constituent loads from any of the three Prairie Lee Lake tributaries; however, the largest contributions of constituents occurred during the larger storms. Constituent loads from the PI 2 basin seem to be the most consistent, that is, constituent loads increased with storm size for all constituents for all storms (fig. 15). The poor relation between the constituent loads and storm size for the PI3 basin probably was caused by a temporary disturbance in the basin. The stream channel was altered to install public sewer system lines, which resulted in a substantial increase in constituent loads from runoff during the storm with 1.4-in. of precipitation relative to consistent loads 
Table 11. Trophic state classification criteria for Missouri lakes and reservoirs based on chlorophyll a, total nitrogen, and total phosphorus concentrations (modified from Jones and Knowlton, 1993)

[ $\mu \mathrm{g} / \mathrm{L}$, micrograms per liter; $\mathrm{mg} / \mathrm{L}$, milligrams per liter; <, less than; $\geq$, greater than or equal to; >, greater than]

\begin{tabular}{lccc}
\hline Trophlc state & $\begin{array}{c}\text { Chiorophyli a } \\
(\mu \mathrm{g} / \mathrm{L})\end{array}$ & $\begin{array}{c}\text { Total nitrogen } \\
(\mathbf{m g} / \mathrm{L})\end{array}$ & $\begin{array}{c}\text { Total phosphorus } \\
(\mathbf{m g} / \mathrm{L})\end{array}$ \\
\hline Oligotrophic & $<3$ & $<0.3$ & $<0.01$ \\
Mesotrophic & $\geq 3-7$ & $\geq .3-.5$ & $\geq .01-.025$ \\
Eutrophic & $\geq 7-40$ & $\geq .5-1.2$ & $\geq .025-.10$ \\
Hypereutrophic & $>40$ & $>1.2$ & $>.10$ \\
\hline
\end{tabular}

Table 12. Constituent concentrations used in trophic state classification of three reservoirs in west-central Missouri

[Concentrations are median values in surface samples; $\mu \mathrm{g} / \mathrm{L}$, micrograms per liter; $\mathrm{mg} / \mathrm{L}$, milligrams per liter]

\begin{tabular}{|c|c|c|c|c|c|c|}
\hline & \multicolumn{2}{|c|}{ Pralrie Lee Lake } & \multicolumn{2}{|c|}{ Lake Jacomo } & \multicolumn{2}{|c|}{ Harrisonvilie Clty Lake } \\
\hline & Concentration & Trophic state & Concentration & Trophic state & Concentration & Trophic state \\
\hline $\begin{array}{l}\text { Chlorophyll } a \\
(\mu \mathrm{g} / \mathrm{L})\end{array}$ & 12 & Eutrophic & 7 & Mesotrophic & 6 & Mesotrophic \\
\hline $\begin{array}{l}\text { Total nitrogen } \\
\quad(\mathrm{mg} / \mathrm{L})\end{array}$ & .10 & Eutrophic & .70 & Eutrophic & 1.03 & Eutrophic \\
\hline $\begin{array}{l}\text { Total phosphorus } \\
(\mathrm{mg} / \mathrm{L})\end{array}$ & .03 & Eutrophic & .03 & Eutrophic & .02 & Mesotrophic \\
\hline
\end{tabular}

from storms with 0.75 - and 1.25 -in. of precipitation. With the exception of the storm with 1.4-in. of precipitation, the mass and mass per acre loads of constituents from the PI3 basin were the lowest of the three sites. The mass and mass per acre loads of $\mathrm{NH}_{3}$ and $\mathrm{NO}_{3}$ from direct precipitation on Prairie Lee Lake were estimated using 1992 mean annual concentrations from the National Atmospheric Deposition Program site in Ashland, Missouri [fig. 1; National Atmospheric Deposition Program (NRSP-3)/National Trends Network, 1993]. The estimated mass loads of $\mathrm{NH}_{3}$ and $\mathrm{NO}_{3}$ from precipitation on Prairie Lee Lake exceeded loads from some tributary basins during several of the smaller (less than 1.4-in. of precipitation) storms. When put in terms of mass per acre, the loads of $\mathrm{NH}_{3}$ and $\mathrm{NO}_{3}$ from direct precipitation exceeded loads of these constituents from tributary runoff during most storms.

The mass and mass per acre loads of total suspended solids, $\mathrm{NH}_{3}, \mathrm{NO}_{3}$, and TP from the Lake Jacomo inflow site are similar to the smallest loads of these constituents from individual Prairie Lee Lake inflow basins for two concurrent storms with 1.25 - and 1.75-in. of precipitation (fig. 16). The sum of the constituent loads into Prairie Lee Lake from the three major inflow basins was more than three times the sum of the outflow loads during these two storms, indicat- ing that Prairie Lee Lake "trapped" suspended solids and nutrients that would have otherwise entered Lake Jacomo. The mass and mass per acre loads of $\mathrm{NH}_{3}$ and $\mathrm{NO}_{3}$ from the Prairie Lee Lake outflow into Lake Jacomo were substantially less than loads from direct precipitation on the reservoir.

The runoff loads of total suspended solids, dissolved $\mathrm{NH}_{3}, \mathrm{NO}_{3}$, and TP determined for the Harrisonville City Lake tributaries varied between sites and storms (fig. 17). In terms of mass, the largest single storm loads of all the constituents occurred during storms with less than 1.5 -in. of precipitation from the $\mathrm{HI} 2$ and HI 3 basins. The HI 2 and HI 3 basins primarily are in agricultural land use that causes large temporal variations in land cover. Loads of all four constituents from the HI1 basin increased with increasing precipitation. The HI1 basin was the least disturbed of the three basins sampled, and the land use includes a golf course, pasture, and a relatively small amount of cropland as compared to the agricultural land use in the HI2 and HI3 basins. The higher loads of total suspended solids from the HI2 and HI 3 sites were evident from the results of the sediment depth survey map, because sediment depths were greater in the lake downstream from the HI2 and HI3 tributaries than downstream from the HI1 tributary (fig. 5). The 1992 mean concentrations of $\mathrm{NH}_{3}$ and $\mathrm{NO}_{3}$ in precipitation 


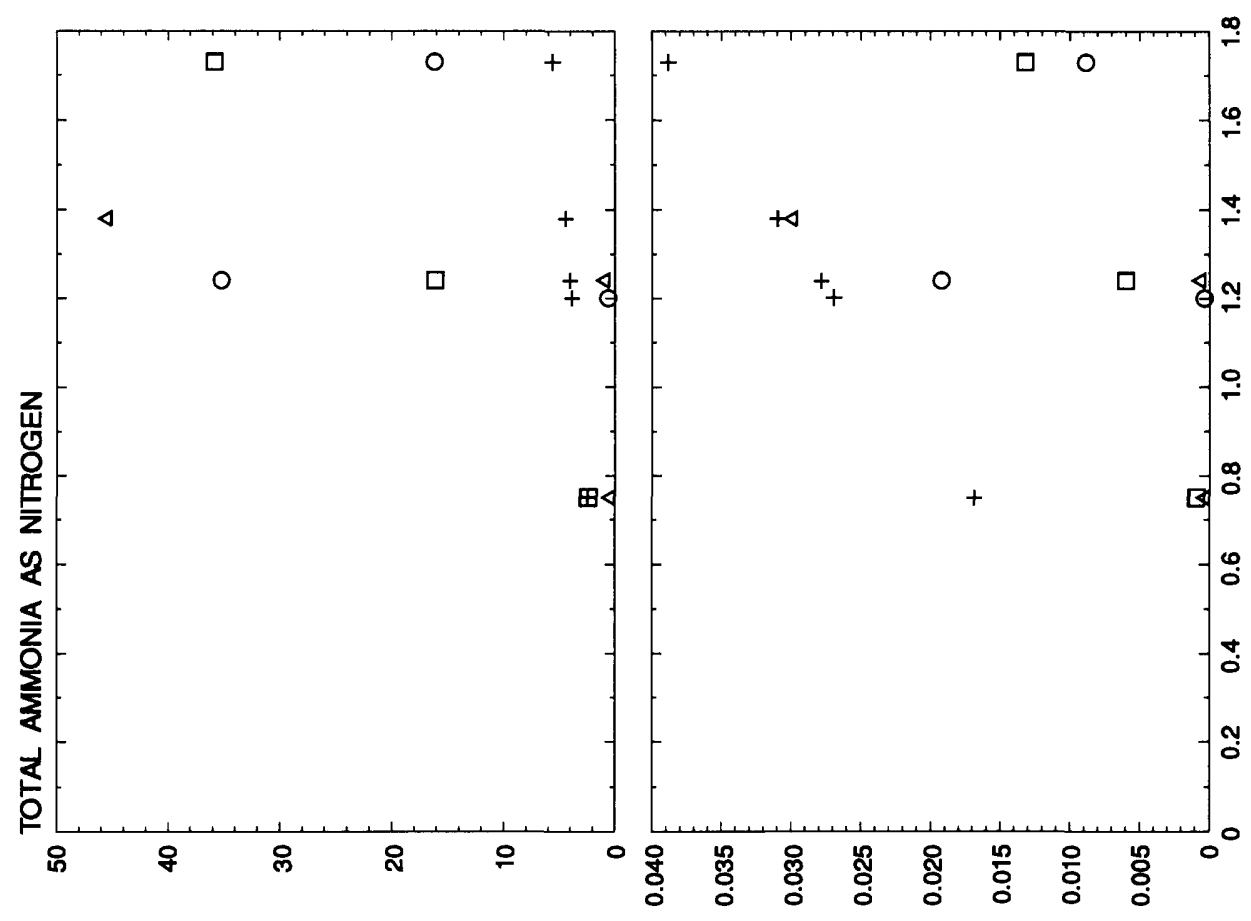

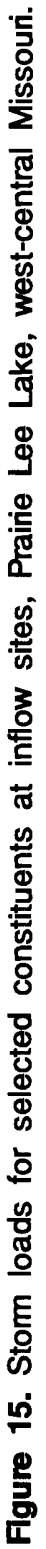



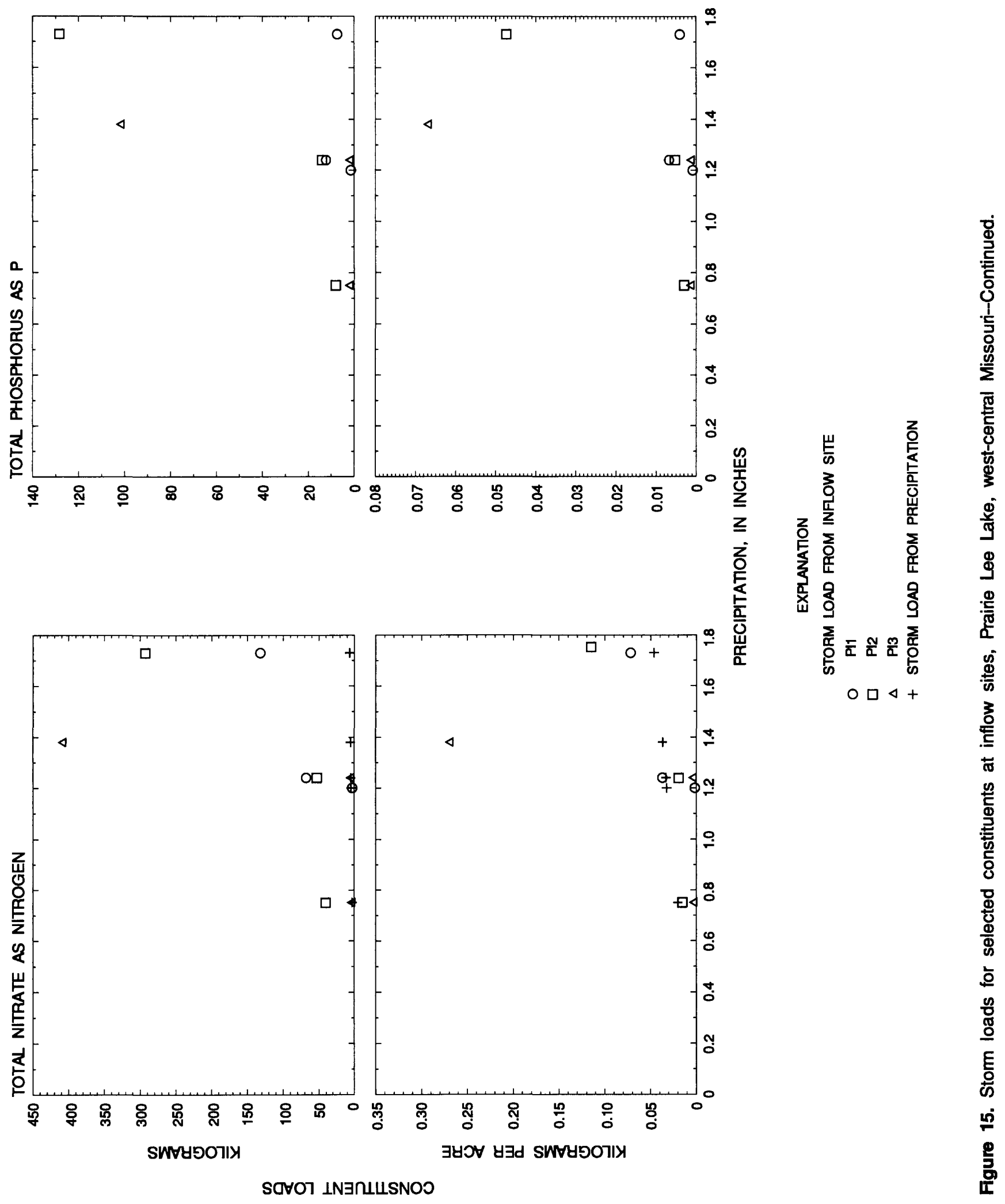

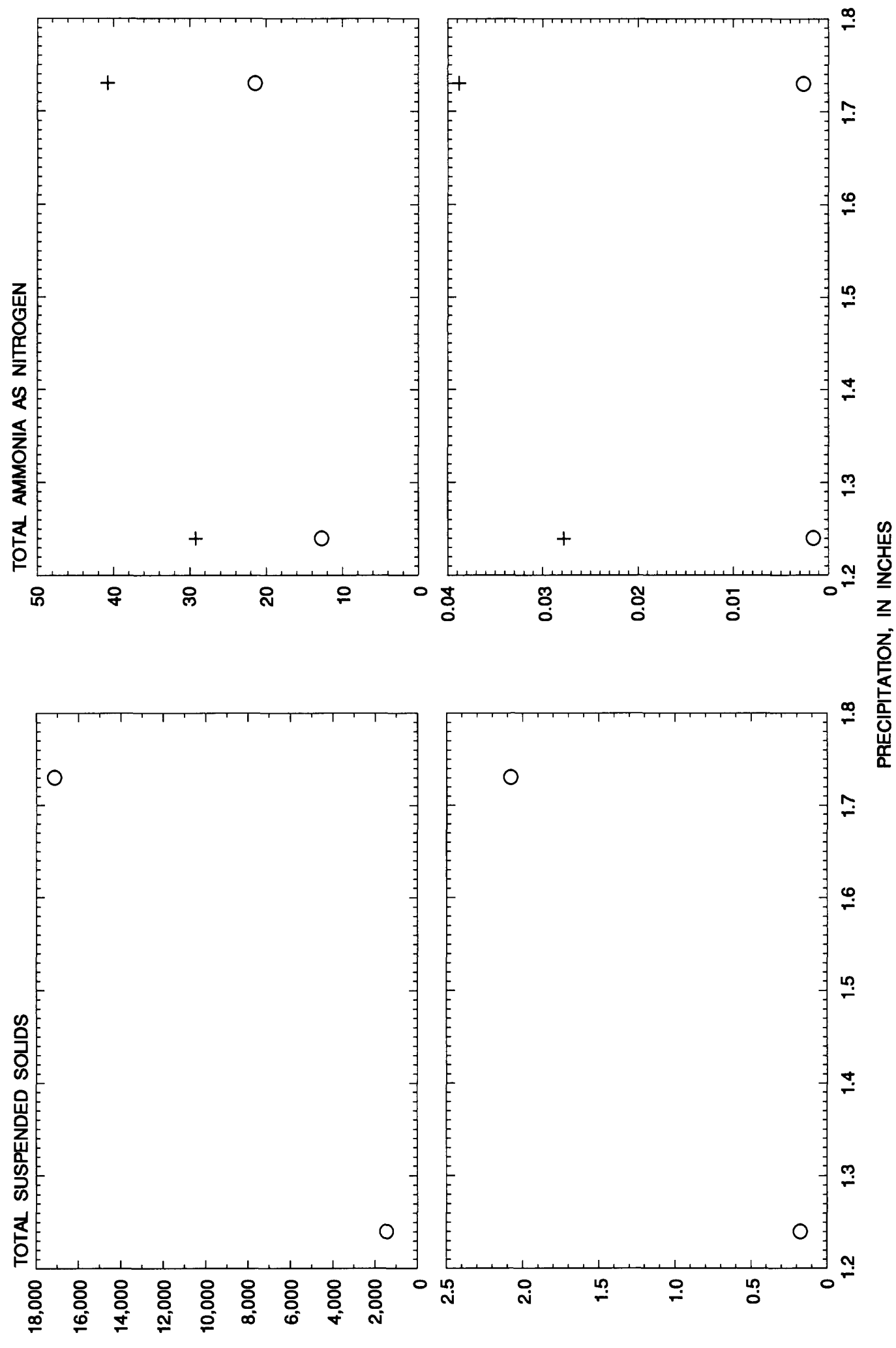

둥

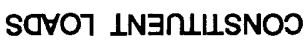



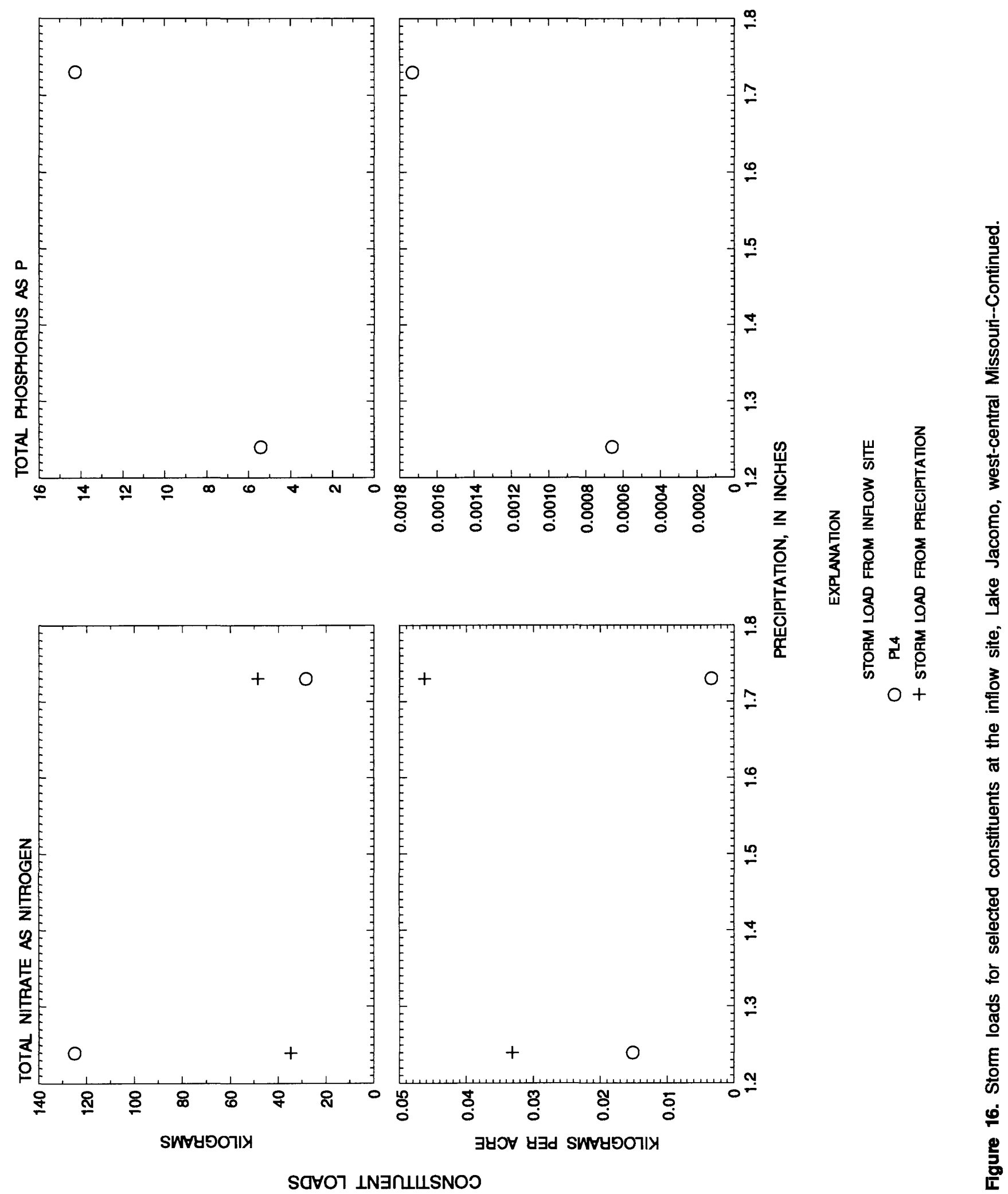


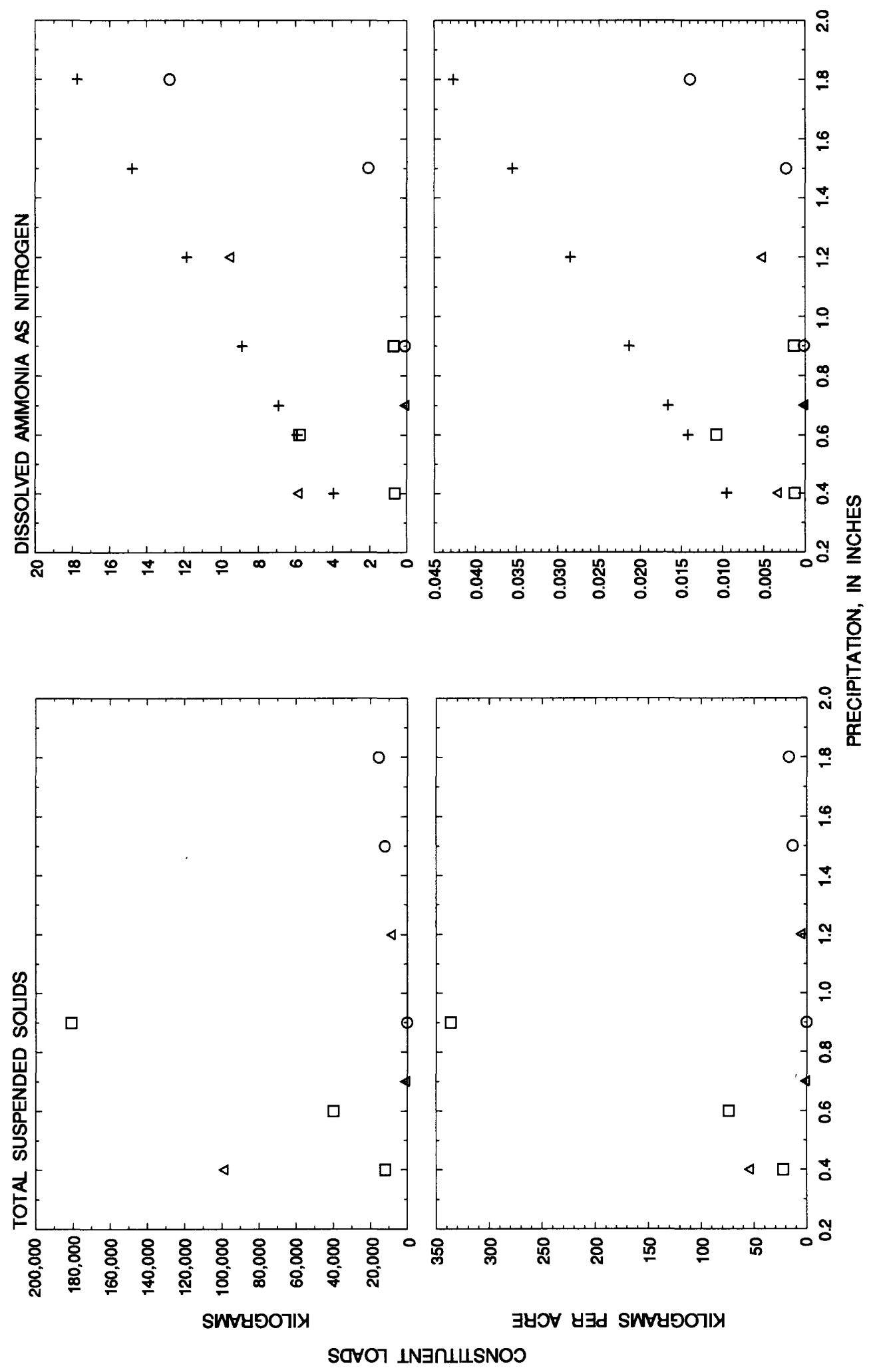

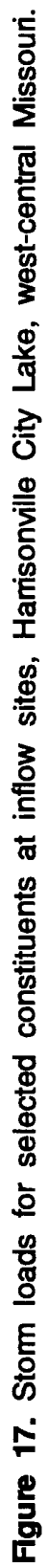



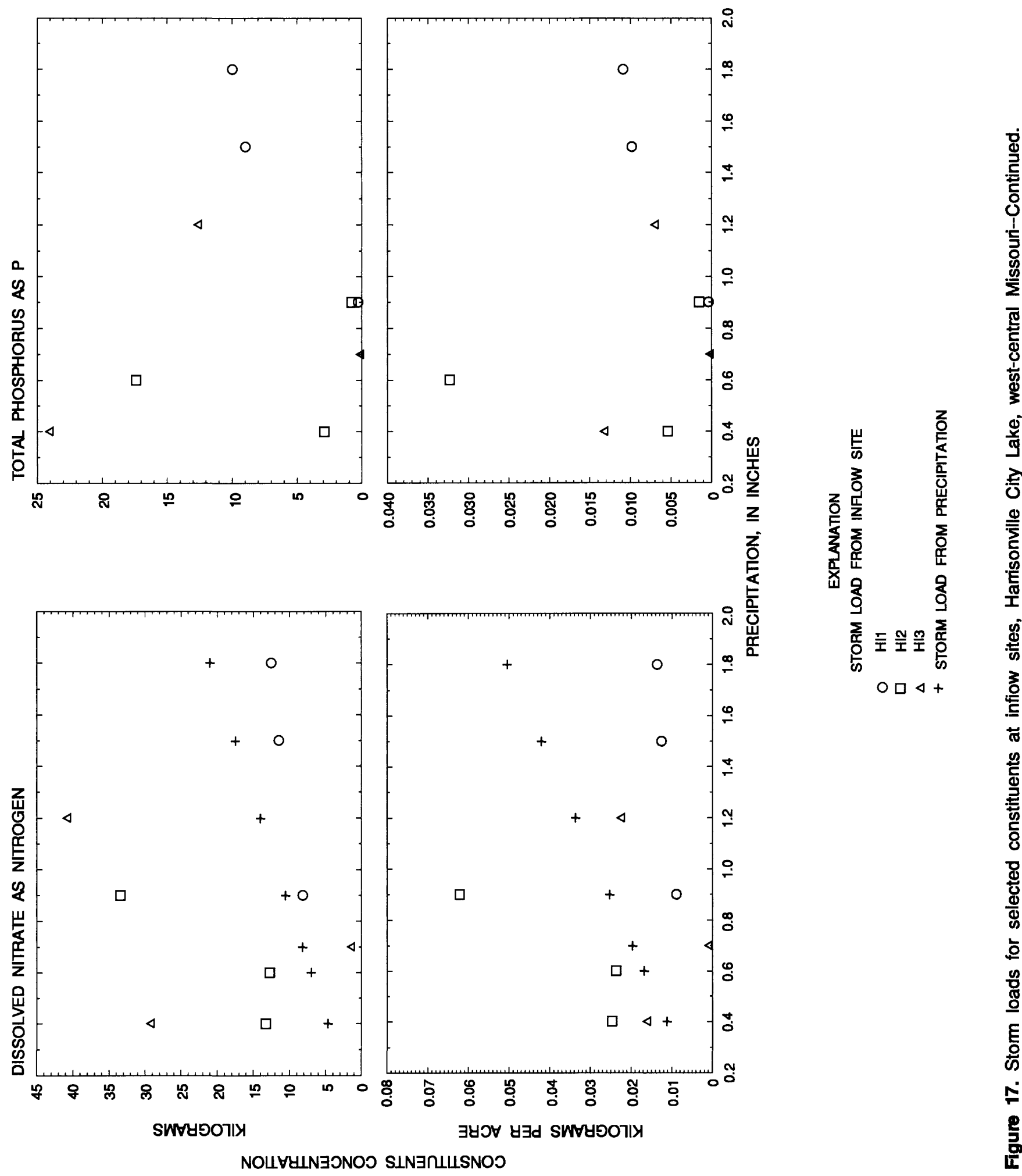
from the National Atmospheric Deposition Program site in Ashland, Missouri (fig. 1), were used to estimate concentrations of these constituents in precipitation during the 1992-93 sampling period (National Atmospheric Deposition Program, 1993). The mass loads of $\mathrm{NH}_{3}$ from all basins were less than that from precipitation for all but one storm, and the mass per acre loads of $\mathrm{NH}_{3}$ from the basins were less than loads from precipitation on the reservoir for all storms. The mass and mass per acre loads of $\mathrm{NO}_{3}$ from the $\mathrm{HI} 1$ basin were less than loads from precipitation for each storm, but the mass loads from HI 2 and HI 3 exceeded those from precipitation during all but one storm. The mass per acre loads from HI2 exceeded loads from precipitation for all storms.

\section{Pesticide Analysis}

Water samples from the three Harrisonville City Lake inflow sites were analyzed for 13 pesticides; 7 of these were detected during this study (table 13, at the back of this report). Thirty-six samples were collected monthly from April 1992 through June or July 1993 and during three selected storms. Pesticides detected include (listed in decreasing frequency of detection) atrazine, desethylatrazine, metolachlor, deisopropylatrazine, alachlor, propazine, and prometon. Concentrations of atrazine detected in samples from the sites ranged from 0.07 to $28.0 \mu \mathrm{g} / \mathrm{L}$ and exceeded the health-based MCL of $3 \mu \mathrm{g} / \mathrm{L}$ in three samples. No other pesticide was detected in concentrations that exceeded established health-based limits.

Based on inconsistencies between the reservoir and inflow pesticide data, additional emphasis would need to be placed on spring and summer runoff sampling to accurately determine loads of pesticides in Harrisonville City Lake. Although ametryn was detected in 32 reservoir samples and cyanazine was detected in 1 reservoir sample (table 10), these compounds were not detected in any of the inflow samples. Prometon was detected in one inflow sample, but it was not detected in any of the reservoir samples.

\section{Reservoir Bottom Sediments}

Bottom sediments were sampled at the three reservoirs and analyzed for volatile solids, nutrient, and trace element concentrations (table 14). There seems to be a direct relation between volatile solids concentration, an indication of organic matter content, and nutrient concentration in most bottom sediment sam- ples. The nutrient (TN and TP) concentrations in bottom sediment samples from one or more sites in each reservoir exceeded those concentrations detected in reference samples of sandstone, shale, and limestone (Hem, 1985), indicating additional anthropogenic contributions were present. The trace element concentrations in bottom sediments of the three reservoirs generally were within the reported concentration range of trace elements listed for the reference samples. The deepest reservoir sampling sites PL2, LJ3, and HL2 (table 1) tended to have the largest concentrations of nutrients and trace elements.

The pesticide analyses of bottom sediment samples from Prairie Lee Lake indicated the presence of aldrin, chlordane, DDD, DDE, DDT, dieldrin, endrin, and mirex (table 15). Most of the same pesticides were detected in Lake Jacomo and Harrisonville City Lake, albeit at fewer sites in lower concentrations than in Prairie Lee Lake. These compounds historically have been used in the control of insects in residential areas. Whereas nutrient and trace element concentrations tended to be greater in samples from the deepest sites, the concentrations of pesticides in bottom sediments seemed to have a greater variation between sites.

The technical chlordane (sum of cis-chlordane, trans-chlordane, cis-nonachlor, and trans-nonachlor isomers) concentrations in fish tissue from Prairie Lee Lake exceeded the U.S. Food and Drug Administration's "action level" of $300 \mu \mathrm{g} / \mathrm{kg}$ (micrograms per kilogram) during 1985, 1987, 1988, and 1989 (Alan Buchanan, written commun., 1991). The chlordane concentrations in bottom sediments of Lake Jacomo generally were less than the concentration in Prairie Lee Lake, and the likely source of the chlordane was from Prairie Lee Lake outflows because there is little urban area in the local Lake Jacomo Basin.

In addition to samples collected in October 1992 at Harrisonville City Lake, bottom samples were collected in March and June 1993 and analyzed for additional pesticides. All pesticide concentrations were less than the detection limits, with the exception of 2,4-D, which exceeded the detection limit with a concentration of $69 \mu \mathrm{g} / \mathrm{kg}$ in the March 24, 1993, sample at site HL1.

\section{BIOLOGICAL CHARACTERISTICS}

The results of bacteria and phytoplankton analyses of samples collected from the three reservoirs are presented in the following sections. The results of 


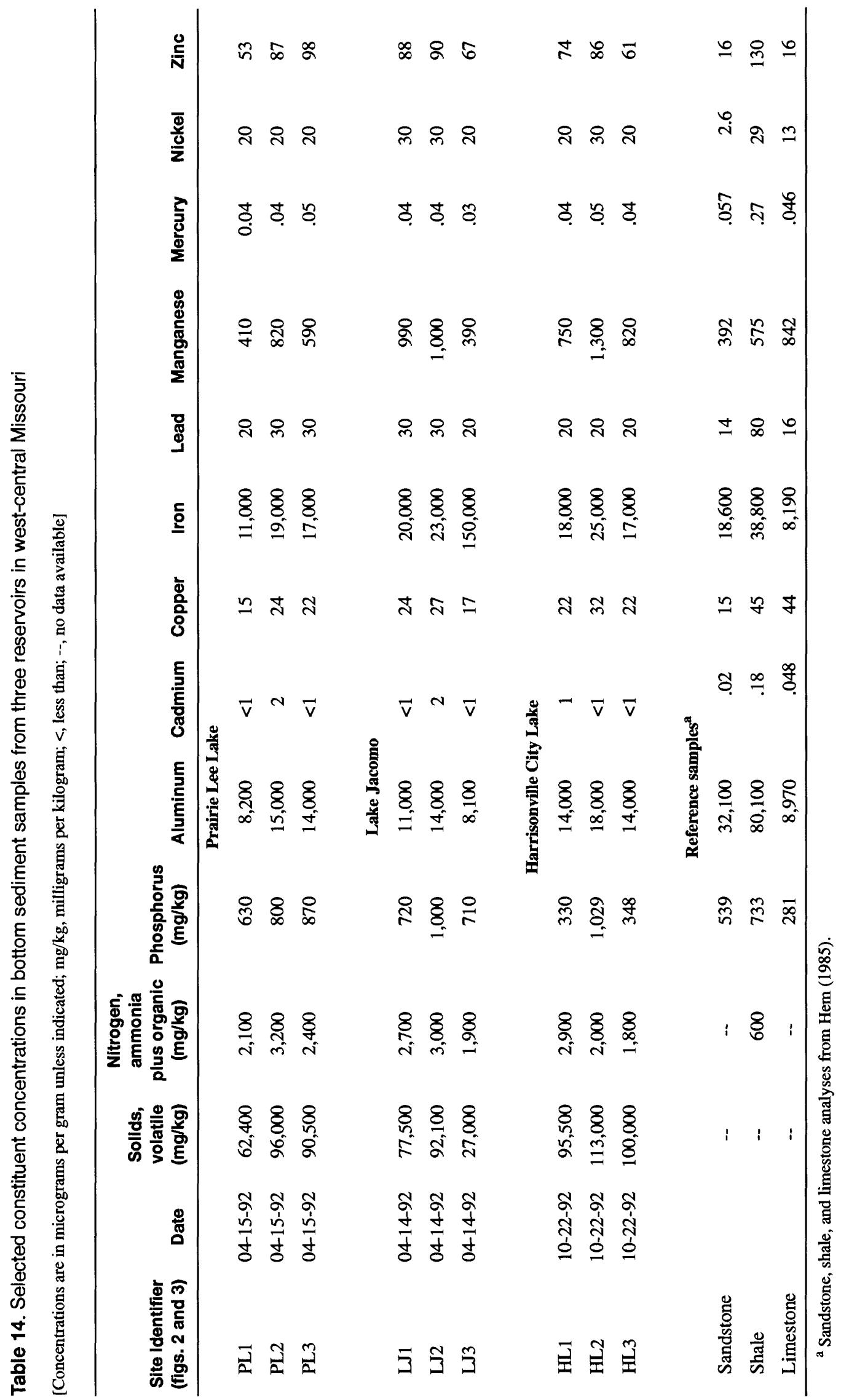




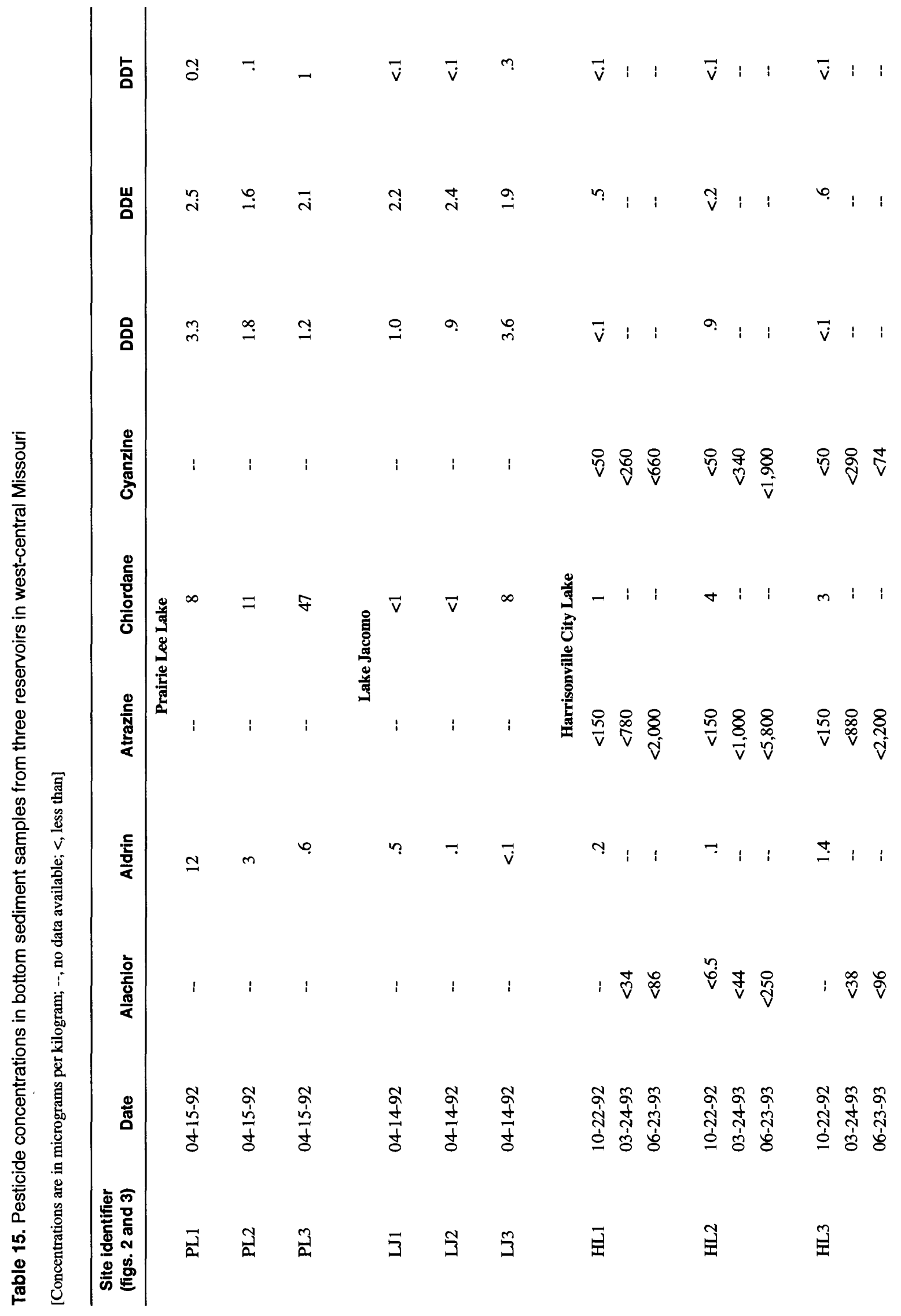




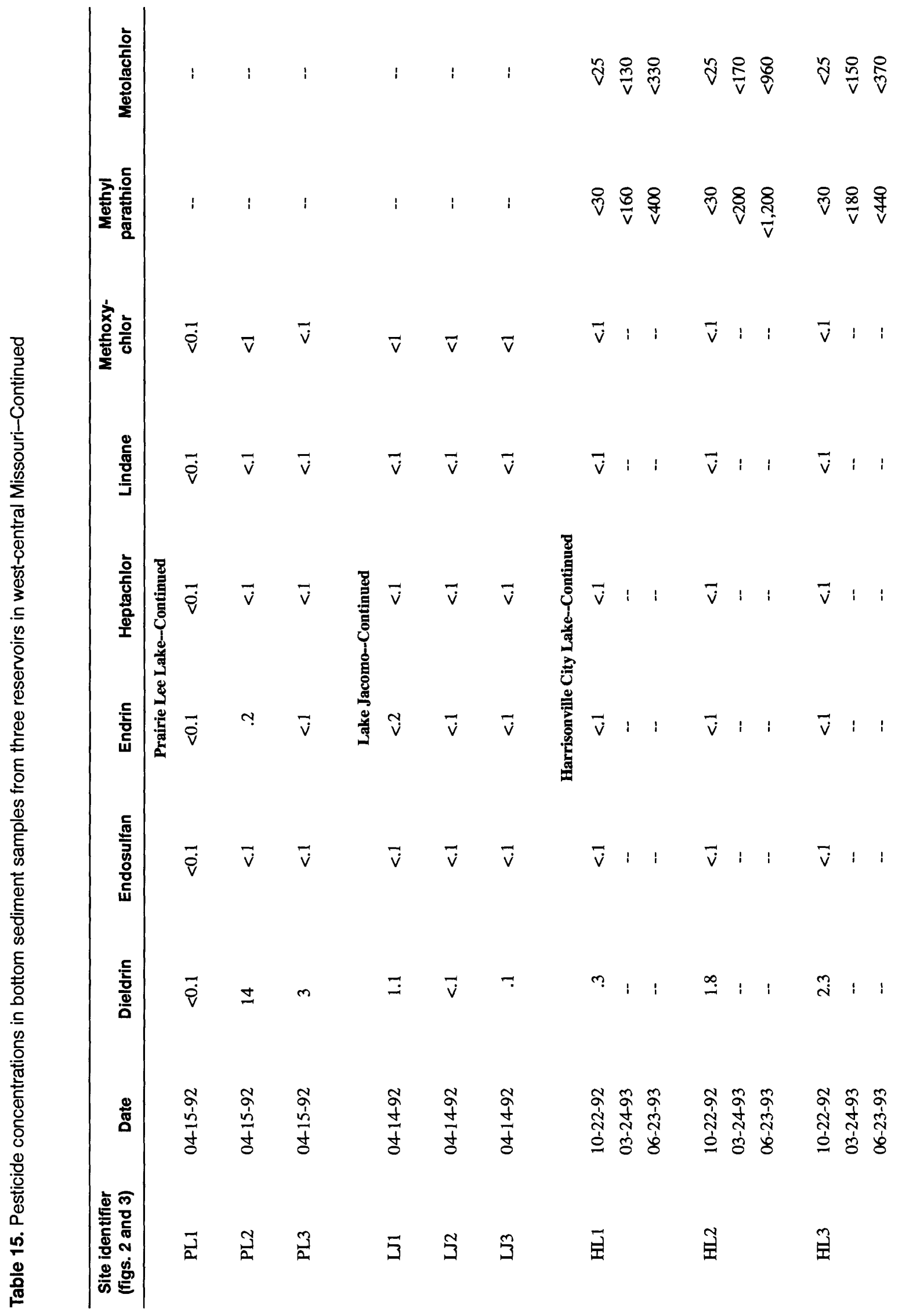




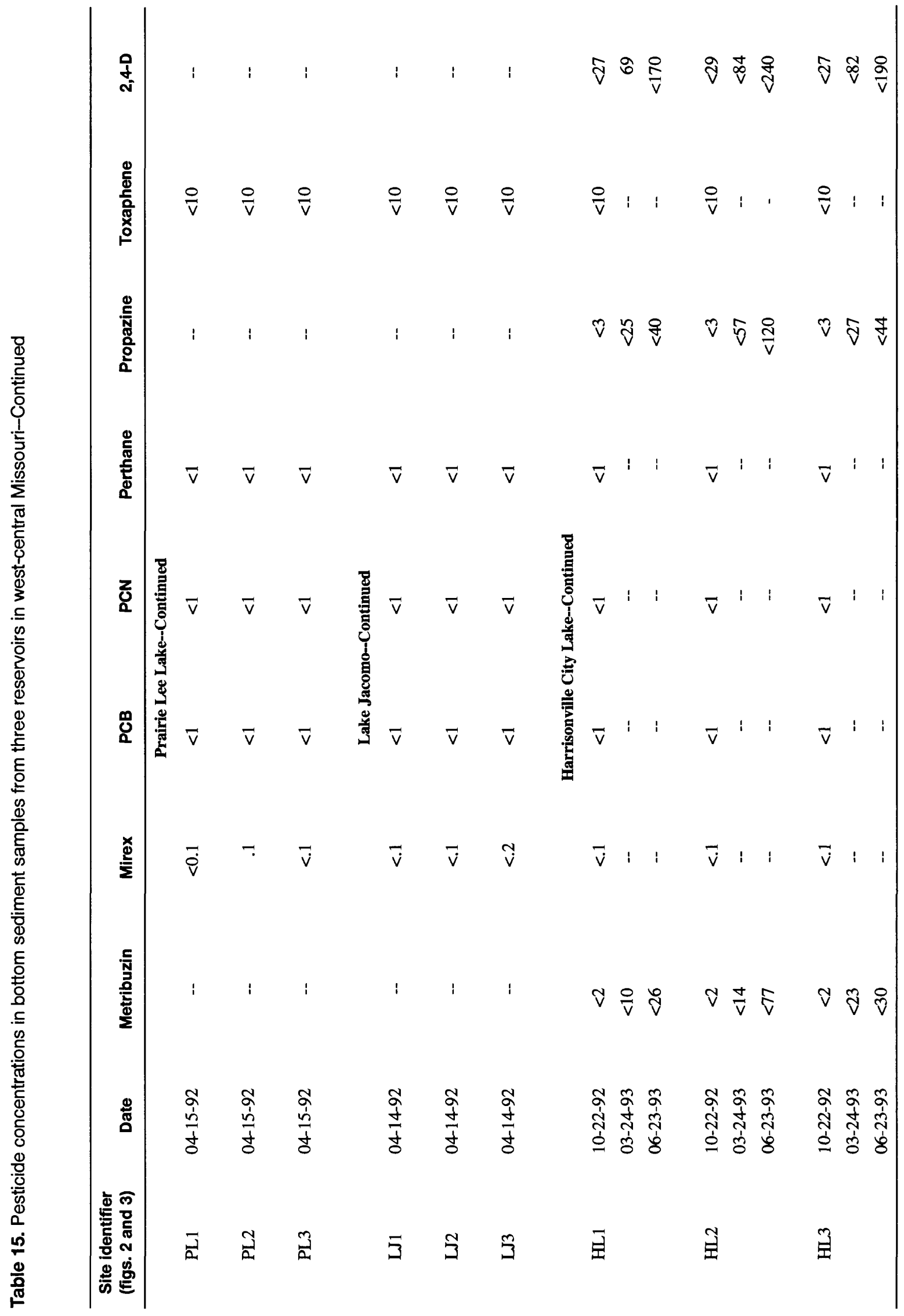


zooplankton analyses of samples collected from Harrisonville City Lake also are discussed.

\section{Bacteria}

Fecal coliform and fecal streptococcal bacteria are used as indicators of contamination of water because the normal habitats for these organisms are the intestines and feces of human and animals (Britton and Greeson, 1987). Missouri has established a standard of $200 \mathrm{col} / 100 \mathrm{~mL}$ for coliform bacteria in surface waters used for whole-body-contact recreation (Missouri Department of Natural Resources, 1992). This standard applies to the recreation season from April 1 through October 31 and during periods when the water body is not affected by stormwater runoff. Fecal coliform densities exceeded $200 \mathrm{col} / 100 \mathrm{~mL}$ in Prairie Lee Lake surface samples at sites PL1 and PL2 on November 18, 1991 (table 16); however, these densities did not exceed State standards because the samples were collected after the recreation season. Fecal coliform densities in surface samples from Lake Jacomo (table 17) and Harrisonville City Lake (table 18) did not exceed $200 \mathrm{col} / 100 \mathrm{~mL}$ during the 12 -month sample period. Fecal coliform densities in bottom samples from Prairie Lee Lake exceeded $200 \mathrm{col} / 100 \mathrm{~mL}$ during the recreation season three times at site PL1, two times at site PL2, and three times at site PL3. No fecal coliform densities in bottom samples from Lake Jacomo exceeded State standards, and two bottom samples from Harrisonville City Lake site HL2 exceeded State standards. The differences in median fecal coliform densities between surface samples or between bottom samples for the sites in an individual reservoir were not significant (Kruskal-Wallis test, $\alpha=0.05$ ). Median fecal streptococcal densities from surface and bottom samples from the three reservoirs were similar to median fecal coliform densities (tables 16 to 18). The differences in median fecal streptococcal densities for surface and bottom samples for sites within an individual reservoir were not significant for any of the three reservoirs (Kruskal-Wallis test, $\alpha=0.05$ ).

Fecal coliform and fecal streptococcal bacteria densities in stormwater-runoff samples from the reservoir inflows (tables 19 to 21 ) were substantially greater than the densities in the reservoir samples, indicating runoff is a major source of bacteria to the study reservoirs. Fecal coliform densities in Prairie Lee Lake inflows ranged from 830 to $600,000 \mathrm{col} / 100 \mathrm{~mL}$; fecal streptococcal densities in these inflows ranged from
9,500 to $380,000 \mathrm{col} / 100 \mathrm{~mL}$ (table 19). Fecal coliform densities in the Lake Jacomo inflow (PL4) during storms ranged from 7 to $10,000 \mathrm{col} / 100 \mathrm{~mL}$, and fecal streptococcal bacteria densities ranged from 17 to $36,000 \mathrm{col} / 100 \mathrm{~mL}$ (table 20). The differences in bacteria densities between Prairie Lee Lake and Lake Jacomo inflows can be attributed to dilution of inflows, die-off of bacteria, and settling of the bacteria into bottom waters. Buckner (1976) studied the population dynamics of fecal coliform and fecal streptococcal bacteria in Prairie Lee Lake and Lake Jacomo and concluded that the primary source of bacteria into these reservoirs was from Prairie Lee Lake inflows during stormwater runoff. Fecal coliform densities in stormwater-runoff samples from Harrisonville City Lake inflows ranged from 4,500 to $310,000 \mathrm{col} / 100 \mathrm{~mL}$, whereas fecal streptococcal densities during runoff ranged from 8,100 to $95,000 \mathrm{col} / 100 \mathrm{~mL}$ (table 21). These high bacteria densities indicate that runoff from inflows also is a primary source of bacteria to this reservoir.

\section{Plankton}

A summary of results from phytoplankton and zooplankton analyses are given in the following sections. Phytoplankton samples were collected from all three reservoirs, whereas zooplankton samples were collected only at Harrisonville City Lake.

\section{Phytoplankton}

Phytoplankton (algae) are microscopic, predominantly free-floating plants. The phytoplankton population of a lake or reservoir is the primary food source for other trophic levels and can have major effects on productivity and water quality. Phytoplankton blooms can adversely affect water quality by producing toxins, decreasing water clarity, or decreasing dissolved oxygen concentrations through die-off and subsequent decomposition.

Temporal peaks in the mean phytoplankton density of cyanophytes (blue-green algae) in surface samples from Prairie Lee Lake occurred in the early June and July 1992 samples, indicative of algal blooms (table 22, at the back of this report; fig. 18). The major phytoplankton density peak (June 3,1992 ) was about 925,000 algal cells/mL (cells per milliliter), 94 percent of which was cyanophytes, primarily Aphanocapsa delicatissima. Cyanophytes are considered "nuisance" 


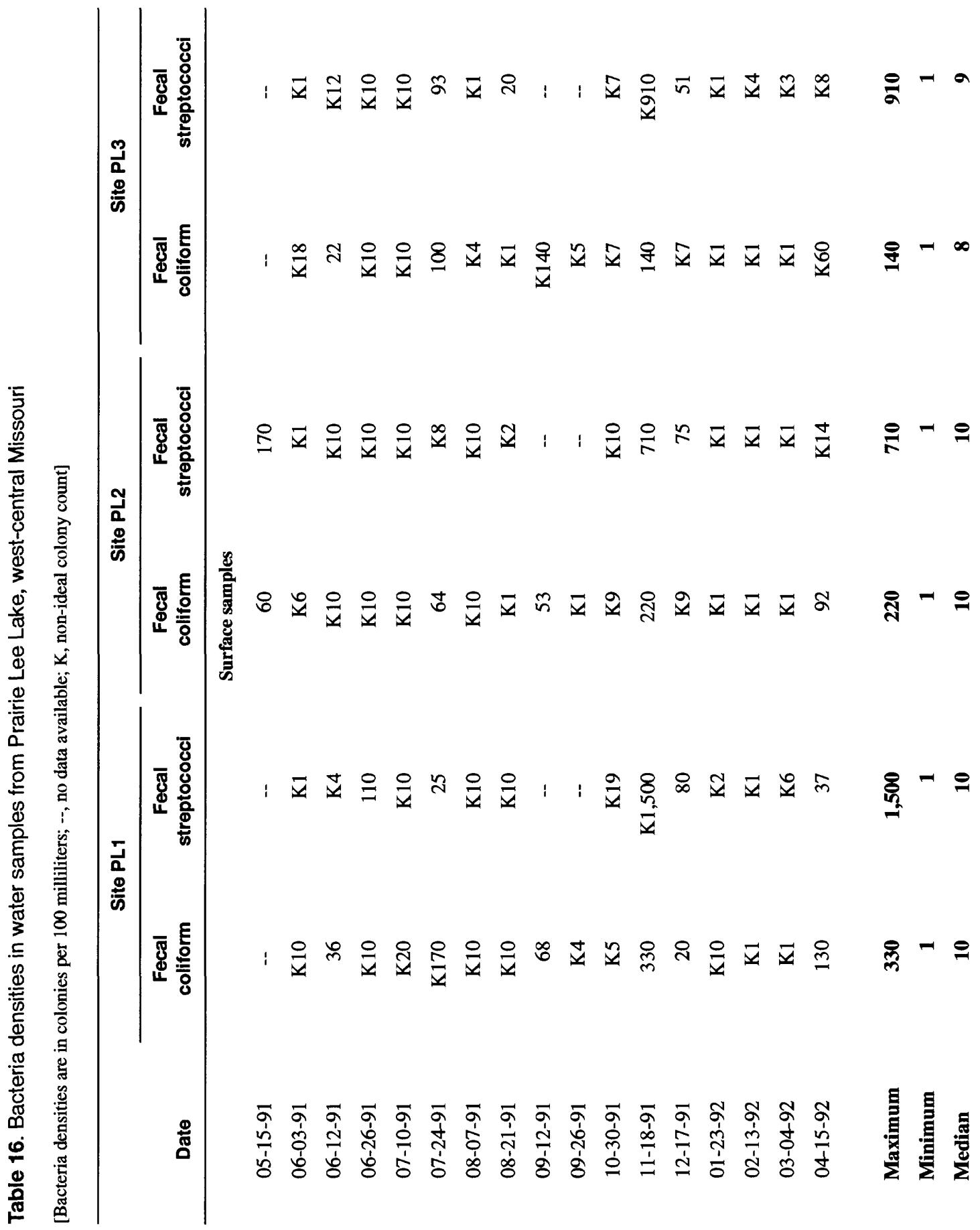




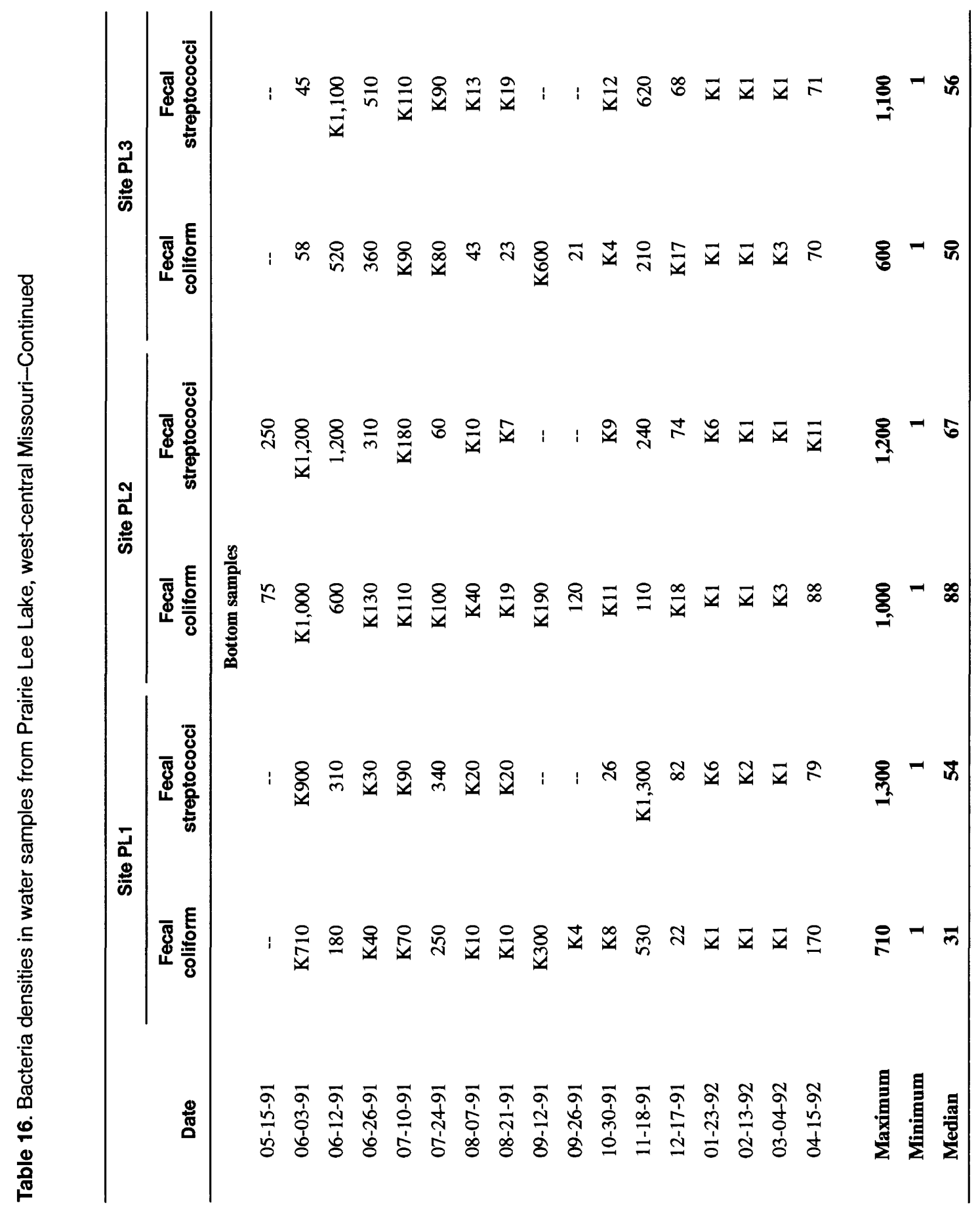




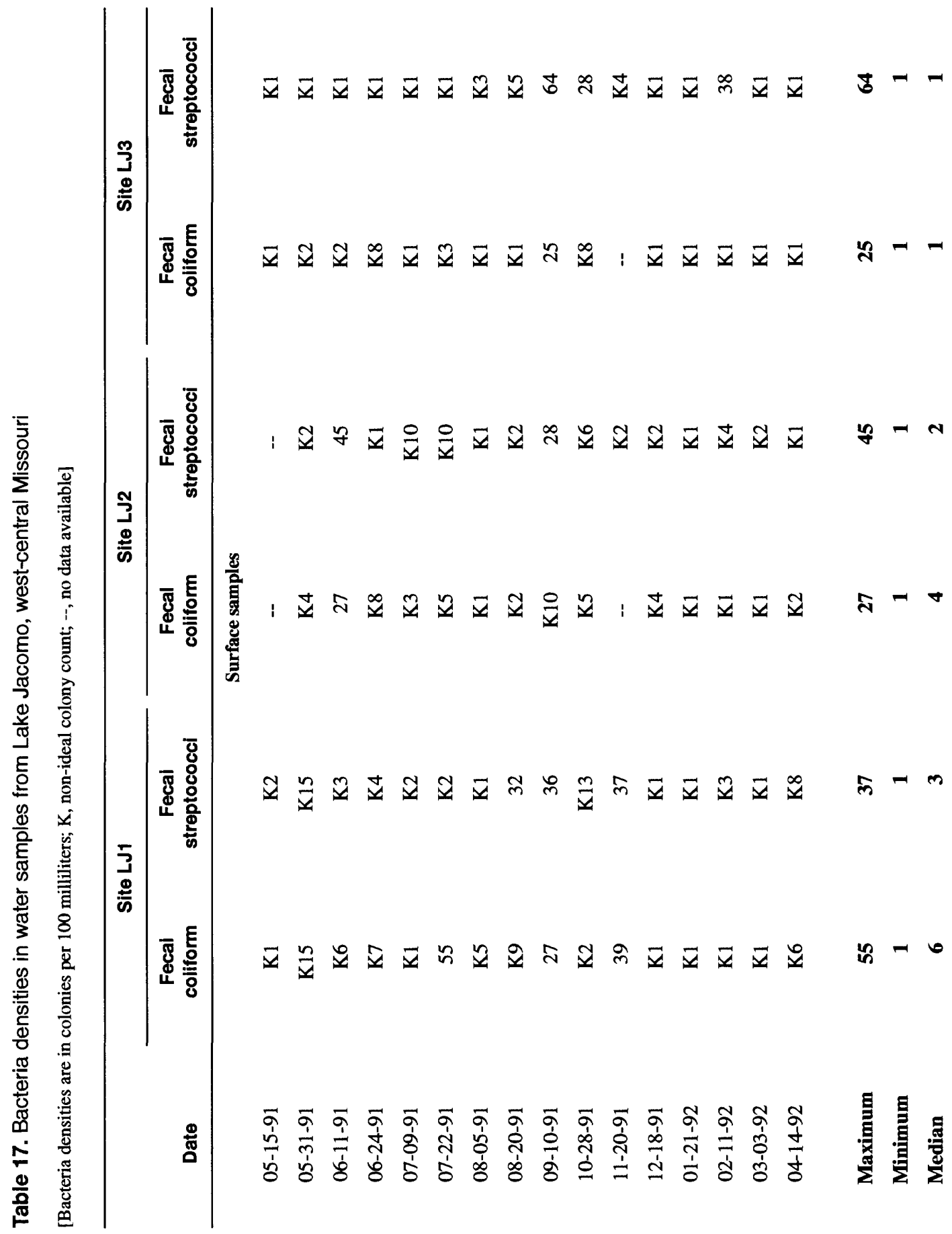




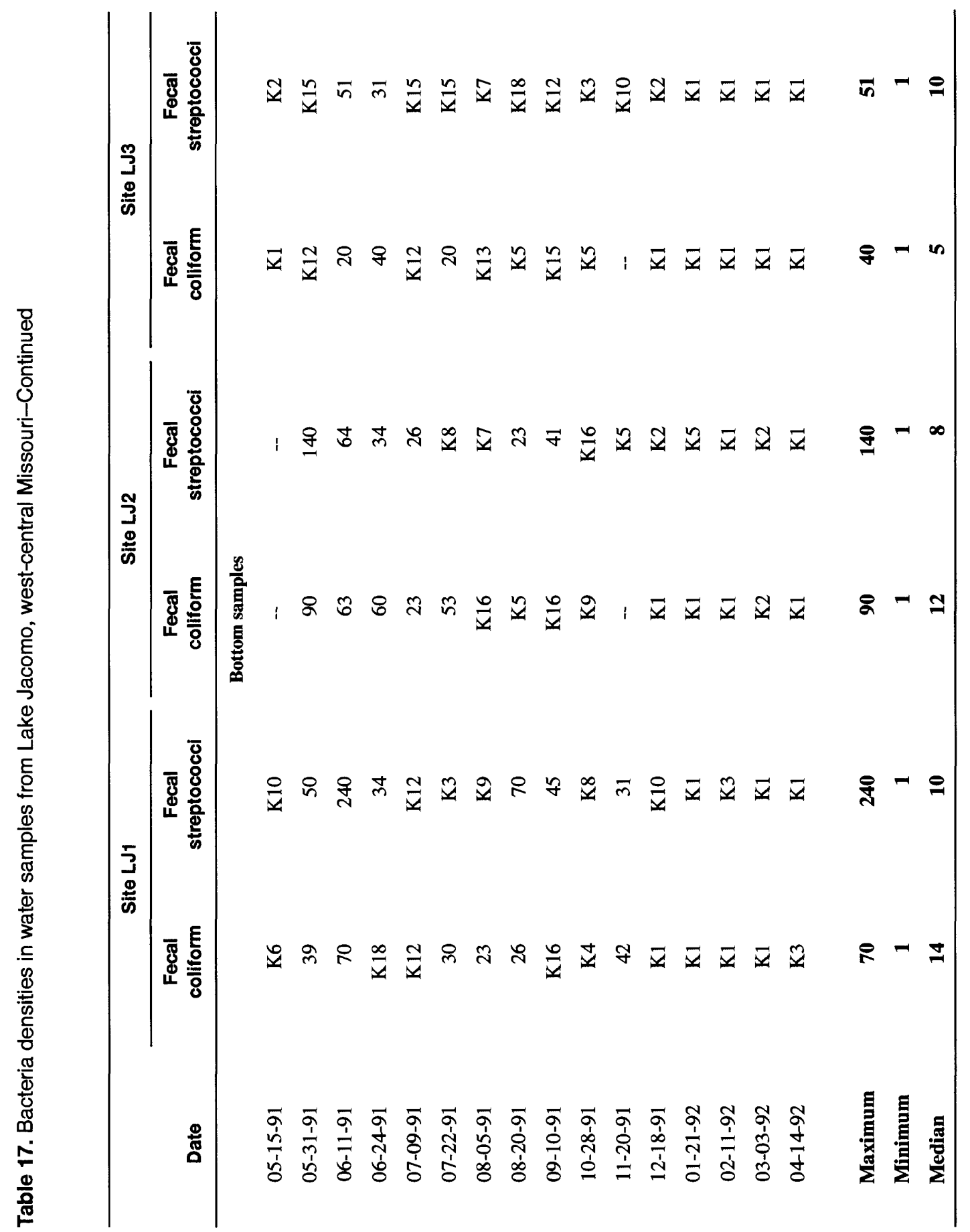




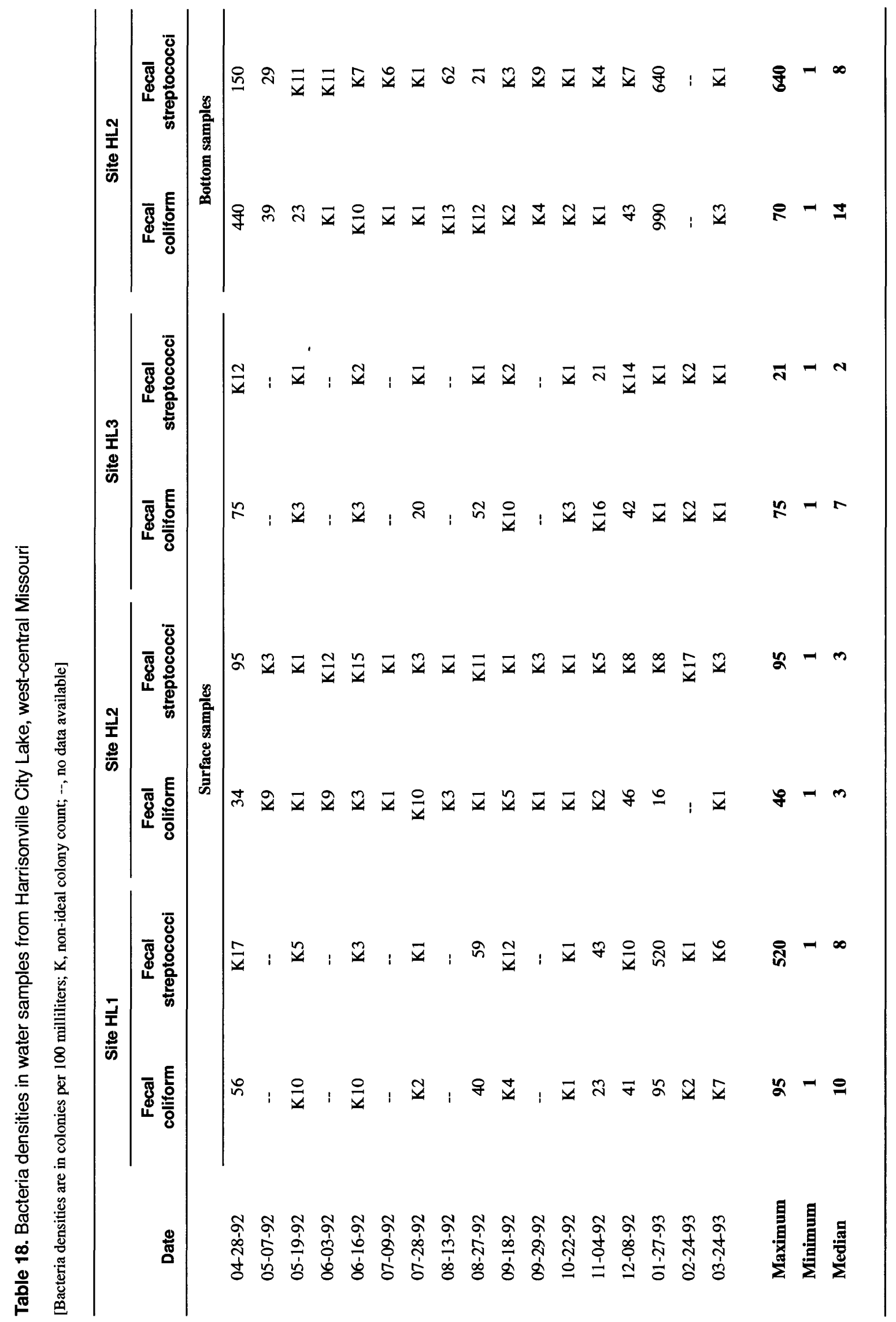


Table 19. Bacteria densities in stormwater-runoff samples in Prairie Lee Lake inflow sites, west-central Missouri [col/100 mL, colonies per 100 milliliters; K, non-ideal colony count; --, no data]

\begin{tabular}{ccccc}
\hline Date & $\begin{array}{c}\text { Number of } \\
\text { samples }\end{array}$ & $\begin{array}{c}\text { Fecal collform } \\
\text { (col/100 mL) }\end{array}$ & $\begin{array}{c}\text { Number of } \\
\text { samples }\end{array}$ & $\begin{array}{c}\text { Fecal streptococci } \\
\text { (col/100 mL) }\end{array}$ \\
\hline $02-14-92$ & 1 & East Fork Little Blue River tributary near Lee's Summit (PI1) & \\
$03-18-92$ & 3 & K830 & 1 & K26,000 \\
$04-19-92$ & 4 & $5,500-40,000$ & 3 & $14,000-\mathrm{K} 110,000$ \\
$04-20-92$ & 3 & K26,000-K500,000 & 4 & $74,000-\mathrm{K} 380,000$ \\
$06-10-92$ & 3 & K160,000-K390,000 & 3 & $51,000-\mathrm{K} 105,000$ \\
& & K480,000-K600,000 & -- \\
$02-14-92$ & 3 & East Fork Little Blue River near Lee's Summit (PI2) & \\
$03-18-92$ & 2 & $1,900-3,300$ & 3 & $9,800-\mathrm{K} 35,000$ \\
$03-19-92$ & 1 & $11,000-14,000$ & 2 & $\mathrm{~K} 54,000$ \\
$04-19-92$ & 5 & 14,000 & 1 & $\mathrm{~K} 58,000$ \\
$04-20-92$ & 2 & $18,000-37,000$ & 5 & K88,000-K340,000 \\
& & 21,000 & 2 & $50,000-79,000$ \\
$02-14-92$ & 2 & Unnamed creek near Lee's Summit (PI3) & \\
$03-18-92$ & 2 & $2,400-3,600$ & 2 & K11,000-K64,000 \\
$04-20-92$ & 4 & $4,500-6,800$ & 2 & $9,500-22,000$ \\
\hline
\end{tabular}

Table 20. Bacteria densities in stormwater-runoff samples from Lake Jacomo inflow site PL4, west-central Missouri [Bacteria densities are in colonies per 100 milliliters; $\mathrm{K}$, non-ideal colony count]

\begin{tabular}{ccccc}
\hline Date & $\begin{array}{c}\text { Number of } \\
\text { samples }\end{array}$ & Fecal collform & $\begin{array}{c}\text { Number of } \\
\text { samples }\end{array}$ & Fecal streptococcl \\
\hline $02-17-92$ & 1 & 32 & 1 & 30 \\
$03-18-92$ & 2 & $\mathrm{~K} 7-25$ & 2 & $\mathrm{~K} 19-64$ \\
$03-19-92$ & 1 & $\mathrm{~K} 200$ & 1 & $\mathrm{~K} 240$ \\
$04-19-92$ & 3 & $36-100$ & 3 & $\mathrm{~K} 17-340$ \\
$04-20-92$ & 1 & $\mathrm{~K} 10,000$ & 2 & $\mathrm{~K} 1,000-36,000$ \\
$04-21-92$ & 1 & $\mathrm{~K} 8,200$ & 1 & $\mathrm{~K} 11,000$ \\
\hline
\end{tabular}

Table 21. Bacteria densities in stormwater-runoff samples from Harrisonville City Lake inflow sites, west-central Missouri [Bacteria densities are in colonies per 100 milliliters; $\mathrm{K}$, non-ideal colony count]

\begin{tabular}{ccccc}
\hline Date & $\begin{array}{c}\text { Number of } \\
\text { samples }\end{array}$ & $\begin{array}{c}\text { Fecal } \\
\text { collform }\end{array}$ & $\begin{array}{c}\text { Number of } \\
\text { samples }\end{array}$ & $\begin{array}{c}\text { Fecal } \\
\text { streptococal }\end{array}$ \\
\hline $11-18-92$ & 5 & $\begin{array}{c}\text { South Fork Muddy Creek near Harrisonville (HI) } \\
\text { Muddy Creek near Harrisonville (HI2) }\end{array}$ & 5 & \\
$11-22-92$ & 3 & $12,000-22,000$ & 3 & \\
$04-13-93$ & 2 & $25,000-47,000$ & 2 & $35,000-55,000$ \\
$07-01-93$ & 1 & K79,000 & 1 & $19,000-83,000$ \\
& & North Fork Muddy Creek near Harrisonville (HI3) & K88,000 \\
$11-19-92$ & 3 & $19,000-22,000$ & 3 & \\
$04-13-93$ & 2 & $25,000-45,000$ & 2 & $61,000-67,000$ \\
& & & $8,100-9,900$ \\
\hline
\end{tabular}


PRARIE LEE LAKE
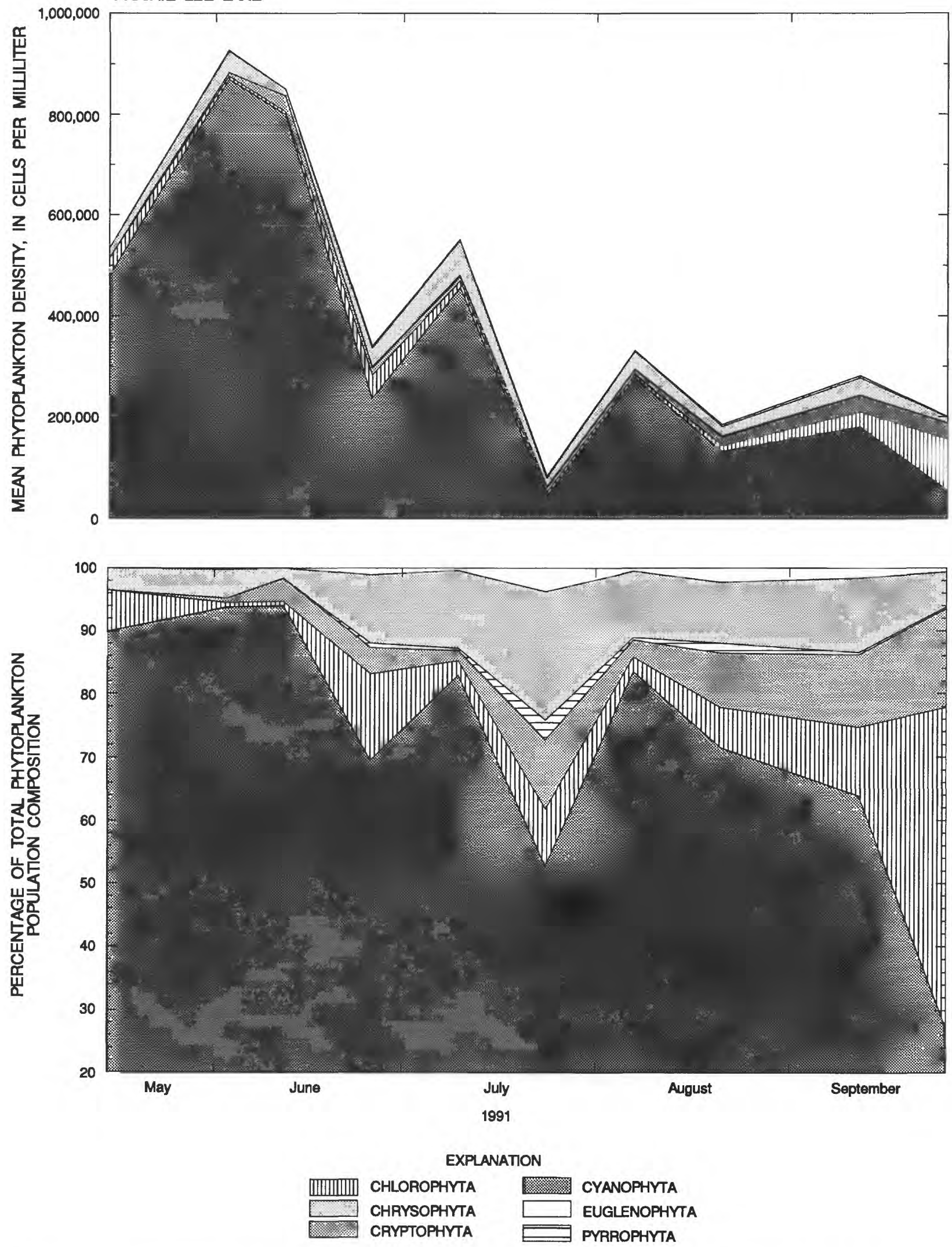

Flgure 18. Phytoplankton density and composition by taxonomic division from surface samples from three reservoirs in west-central Missoun. 

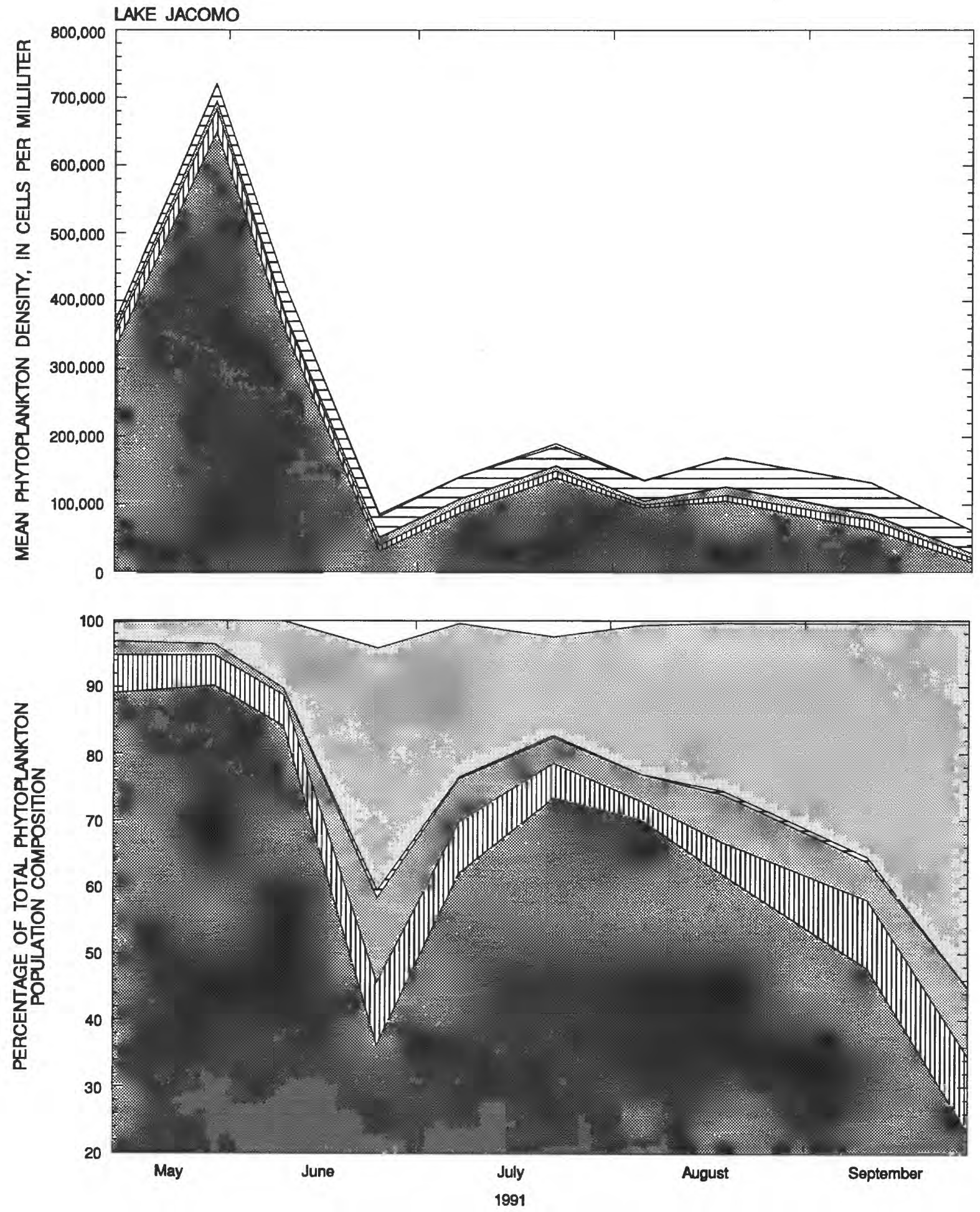

\section{EXPLANATION}

Figure 18. Phytoplankton density and composition by taxonomic division from surface samples from three reservoirs in west-central Missouri-Continued. 

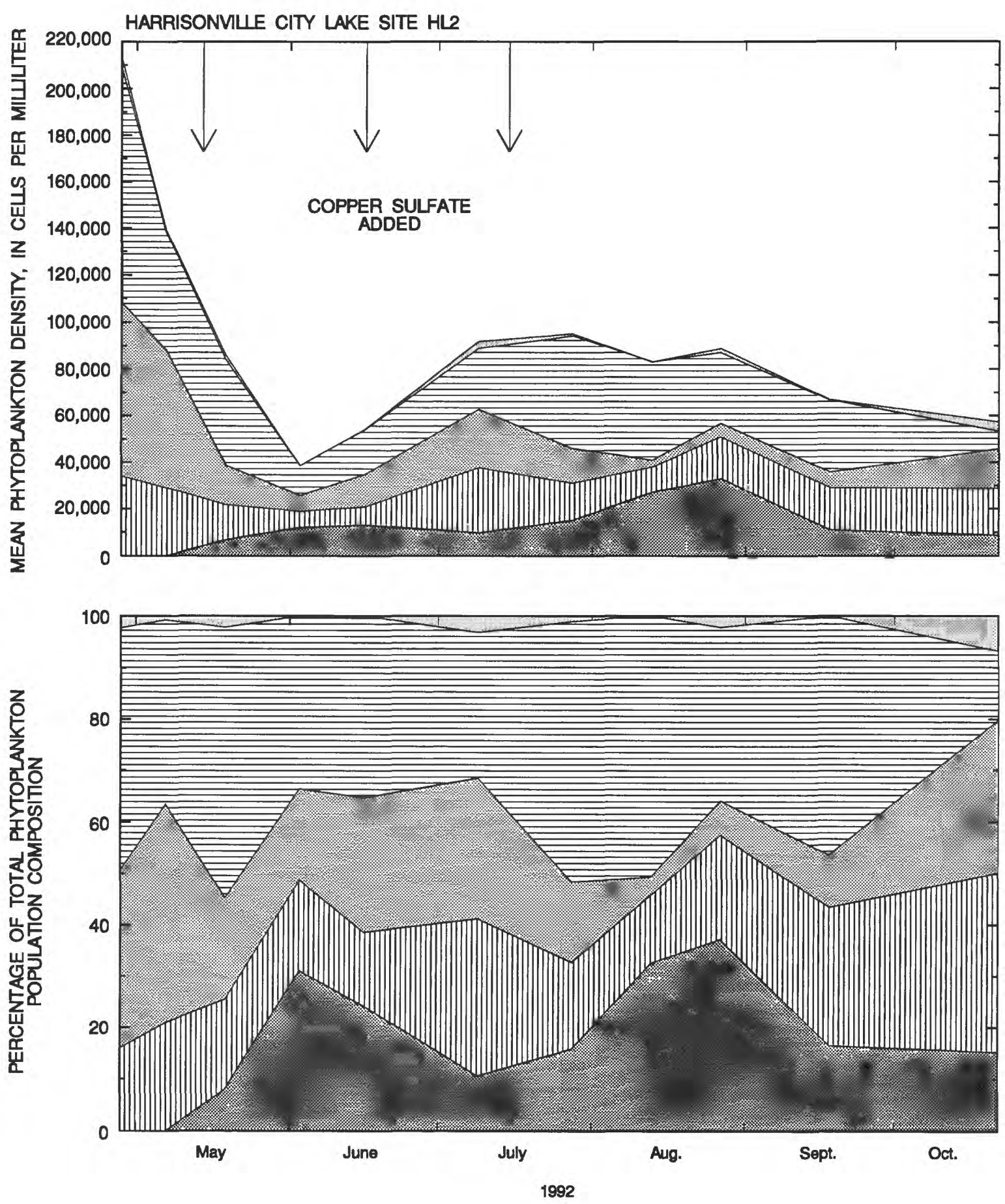

EXPLANATION

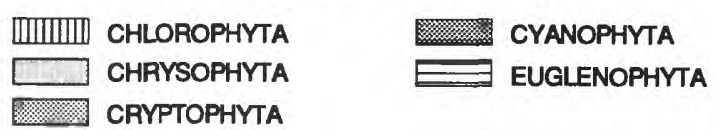

Fgure 18. Phytoplankton density and composition by taxonomic division from surface samples from three reservoirs in west-central Missouri--Continued. 
algae and commonly are associated with taste, odor, and aesthetic concerns in lakes and reservoirs. In the summer, when temperatures are high and inorganic nutrients are low, many cyanophytes are capable of fixing elemental $\mathrm{N}$, thus enabling them, in part, to dominate other types of phytoplankton once they are established in a lake or reservoir (Bush and Welch, 1972). The mean surface phytoplankton density in Prairie Lee Lake reached a summer low in July 1991 following a second summer peak in the phytoplankton population. The cell density remained relatively low in the August and September samples, and the composition began to diversify near the end of September when the phytoplankton population became dominated by chlorophytes (primarily Ankistrodesmus sp.) rather than the cyanophyte species (fig. 18). This change in the phytoplankton composition may be explained by the introduction of additional nutrients, which may have been at growth-limiting levels for many of the other phytoplankton species, into the surface waters after fall destratification (Shapiro, 1973).

The temporal distribution of mean phytoplankton density in surface samples from Lake Jacomo indicates the May 30,1991, samples contained the highest mean phytoplankton density at about 725,000 cells $/ \mathrm{mL}$, and the population was dominated by cyanophytes (primarily Aphanocapsa delicatissima; table 22; fig. 18). There was a decline in the algal population in the June 25, 1991, samples to less than 100,000 cells $/ \mathrm{mL}$, and a larger part of the population was comprised of chrysophytes. In the September 27, 1991, samples, the population was dominated by chrysophytes (primarily unknown flagellates), which comprised 55 percent of the total phytoplankton population (fig. 18).

The temporal distribution of phytoplankton density at Harrisonville City Lake was determined using results from surface samples from site HL2 because this site was sampled more frequently during the summer months than the remaining two sites (fig. 18 ; table 22). One hundred and fifty pounds of copper sulfate was added to the west arm of the reservoir in mid-May, mid-June, and mid-July by the city of Harrisonville to control phytoplankton density near the drinking-water supply intake structure (fig. 3), but the effects of this treatment on the phytoplankton population were not determined.

The maximum phytoplankton density in surface samples from site HL 2 was about 210,000 cells $/ \mathrm{mL}$ on April 28, 1992, and the minimum was about 40,000
cells/mL on June 3, 1992 (fig. 18). Phytoplankton of the division Chrysophyta (primarily unknown flagellates) comprised the largest part of the population in all but the August 27 and October 22, 1992, samples. Cyanophytes were not detected in the April 28, 1992, sample, but comprised about 30 percent of the population by June 3, 1992 (primarily Anacystis sp.). The largest percentage of cyanophytes (primarily Oscillatoria $s p$.) in the phytoplankton population was 35 percent in the August 27, 1992, sample. Chlorophytes (primarily Scenedesmus $s p$.) dominated the phytoplankton population in the October 22, 1992, sample.

\section{Zooplankton}

Zooplankton, microscopic free floating animals, are grazers of phytoplankton and the primary food source of fish. Zooplankton are, therefore, an important component of the food chain in aquatic ecosystems. The dominant zooplankton in samples collected from Harrisonville City Lake included two genera of rotifers, five genera of cladocerans, and four genera of copepods (table 23, at the back of this report). These genera are common in Missouri reservoirs (John Havel, Southwest Missouri State University, written commun., 1993) and in other regions of North America (Edmondson, 1959). A notable feature of the October sample was the presence of Daphnia lumholtzi, an exotic but increasingly common species in Missouri reservoirs (John Havel, written commun., 1993). Copepod densities generally were greater than the density of cladocerans or rotifers in the April through August 1992 samples (fig. 19). There was a substantial increase in the cladoceran population in September, and was the largest part of the zooplankton population in September and October. The rotifer population was relatively small throughout the sampling period.

Zooplankton population dynamics are difficult to discern and are affected by numerous factors, including reservoir conditions, phytoplankton population density and composition, interactions with other zooplankton, and feeding characteristics of the vertebrate population. The dominant rotifer detected was Asplanchna, which preys on algae and small zooplankton. The dominant cladoceran genera sampled included Daphnia and Bosmina. Most cladocerans feed on particulate matter filtered from the water column. The copepod population was dominated by species in the genera Diaptomus that mainly feed on 


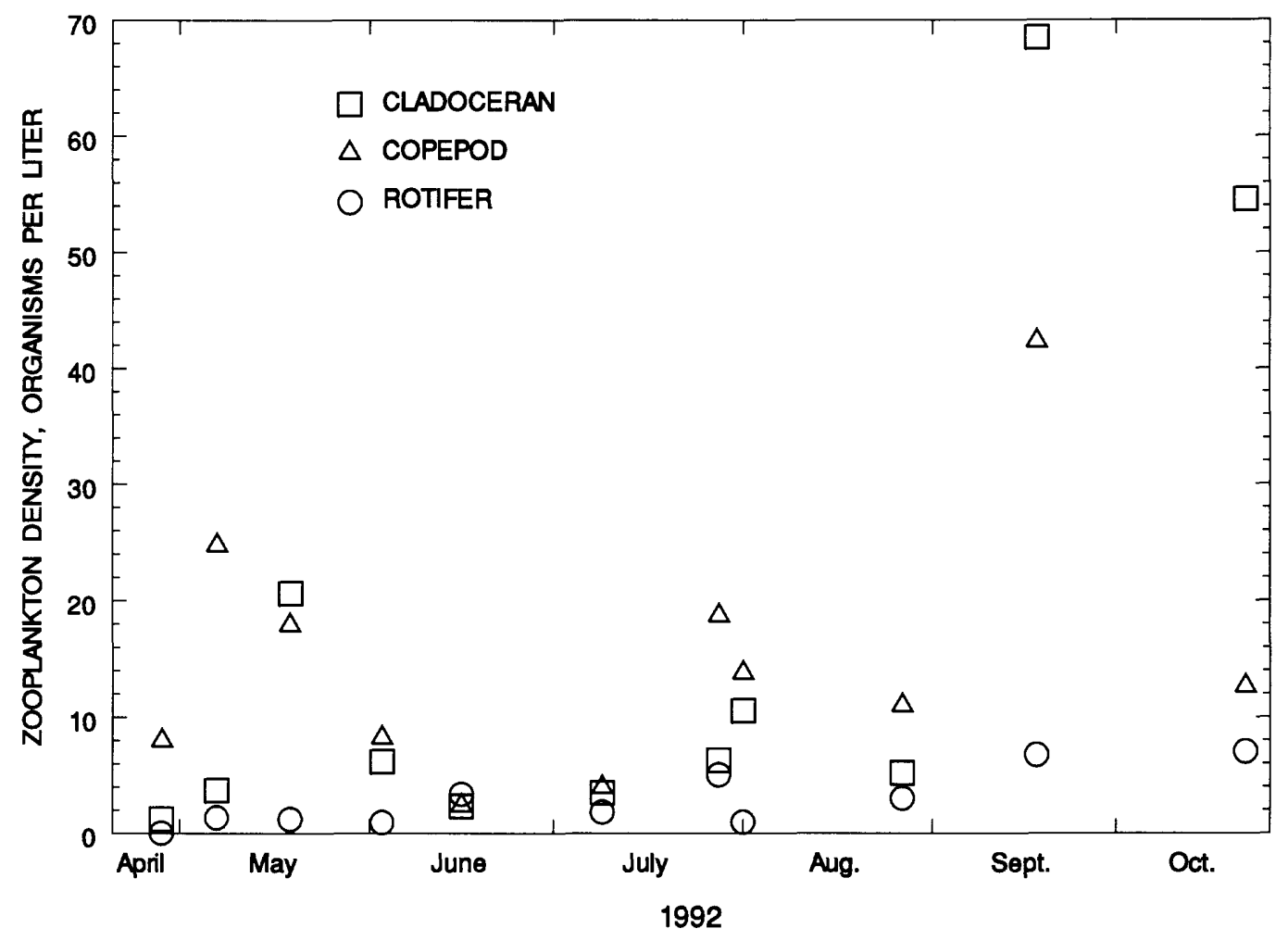

Figure 19. Zooplankton density by taxa, Hamisonville City Lake, west-central Missouri, site HL2.

detritus and phytoplankton (Wetzel, 1983). The autumn peak in zooplankton population could be the result of the increased diversity in the phytoplankton population that corresponded with the onset of fall destratification.

\section{SUMMARY AND CONCLUSIONS}

Water and bottom sediments were sampled in Prairie Lee Lake and Lake Jacomo, Jackson County, Missouri, from May 1991 through April 1992, and were sampled in Harrisonville City Lake, Cass County, from April 1992 through March 1993, to determine general physical, chemical, and biological characteristics of these reservoirs. Water from the major inflows to each reservoir were sampled to determine relative nutrient and sediment contributions from the tributary basins.

Approximately 1,180 acre-feet of sediment had accumulated in Prairie Lee Lake since the dam was built during 1939, resulting in a 29 percent loss in the original reservoir volume. In Lake Jacomo, approximately 1,910 acre-feet have been deposited since
1959 , resulting in an 8 percent loss in original volume. Harrisonville City Lake has accumulated an estimated 1,130 acre-feet of sediment since 1972 , resulting in a 14 percent loss in volume.

The differences in median values of water-clarity characteristics of the reservoirs, including Secchi depth, suspended solids, suspended sediment, and chlorophyll $a$, were compared between sites within an individual reservoir to determine if these differences were significant. The only significant difference detected was in Secchi depth values between Lake Jacomo sites LJ1, LJ2, and LJ3 (Kruskal-Wallis test, $\alpha$ $=0.05$ ). It seems that Secchi depths were significantly lower at site LJ1 because of effects from the outflows of Prairie Lee Lake.

Suspended sediment was the water-clarity characteristics that had the highest correlation with Secchi depth in each reservoir. The correlations were low, however, and Spearman's rank order correlation coefficients for this relation ranged from -0.12 at Harrisonville City Lake to -0.46 at Prairie Lee Lake.

There were no significant differences in physical properties and chemical constituents between sur- 
face sites at any of the three individual reservoirs. There were, however, significant differences (KruskalWallis test, $\alpha=0.05$ ) detected in median specific conductance, alkalinity, total ammonia, and total orthophosphate between some bottom sites within individual reservoirs. These differences can be attributed to the variable effects of thermal stratification and corresponding period of anoxic conditions with water depth.

The temporal distribution of the total nitrogen to total phosphorus ratio calculated from surface water samples in the reservoirs indicate that phosphorus is the nutrient limiting phytoplankton production throughout the spring and summer months. The data are less conclusive during the fall and winter months in Lake Jacomo and Harrisonville City Lake, and additional analyses would be needed to determine the limiting nutrient during these periods.

Water samples from Harrisonville City Lake were analyzed for 20 pesticides, and concentrations of 9 of the 20 pesticides exceeded detection limits. The pesticides detected included atrazine, desethylatrazine, deisopropylatrazine, metolachlor, ametryn, propazine, alachlor, 2,4-D, and cyanazine. Atrazine concentrations were greater than the Federal health-based maximum contaminant level of 3 micrograms per liter in all surface and bottom samples collected between late April and early November 1992 . The mean concentration of atrazine in 36 surface samples was 2.8 micrograms per liter and the mean concentration of atrazine in 11 bottom water samples was 3.3 micrograms per liter. None of the remaining eight pesticides detected exceeded health-based limits.

The trophic condition of the reservoirs were determined using the Trophic-State Index that uses Secchi depths, chlorophyll concentrations, and total phosphorus concentrations. The results were inconsistent over time and between index values, but all three reservoirs can be classified as mesotrophic to

eutrophic. The trophic condition of the three reservoirs also was determined using a classification generated for Missouri lakes and reservoirs using chlorophyll $a$, total nitrogen, and total phosphorus concentrations. Based on these criteria, Prairie Lee Lake is classified as eutrophic, and Lake Jacomo and Harrisonville City Lake are classified as mesotrophic to eutrophic.

The major inflows to each of the three reservoirs were sampled during stormwater runoff and analyzed for suspended solids, ammonia, nitrate, and total phosphorus to determine relative contributions of these constituents. The outflow from Prairie Lee Lake is the major inflow to Lake Jacomo. Based on samples from concurrent storms, the mass and mass per acre loads of suspended solids, ammonia, nitrate, and total phosphorus in Prairie Lee Lake outflow were about onethird the loads of Prairie Lee Lake inflows, indicating Prairie Lee Lake is a sediment and nutrient "trap." The mass per acre contributions of ammonia and nitrate from direct precipitation on Prairie Lee Lake, Lake Jacomo, and Harrisonville City Lake exceeded loads from tributary inflows for most storms.

The Harrisonville City Lake tributaries were sampled for 13 pesticides monthly from April 1992 through June or July 1993 and during selected storms. Seven of the 13 herbicides were detected, including atrazine, desethylatrazine, metolachlor, deisopropylatrazine, alachlor, propazine, and prometon. Atrazine concentrations ranged from 0.12 to 28.1 micrograms per liter and exceeded the maximum contaminant level in three samples.

The spring and summer phytoplankton population in Prairie Lee Lake samples was dominated by cyanophytes. By late summer the chlorophytes became dominant in Prairie Lee Lake, and chrysophytes became dominant in Lake Jacomo possibly as the result of additional nutrient availability following destratification. The phytoplankton population in Harrisonville City Lake was dominated by chrysophytes during much of the spring and summer of 1992. Cyanophytes comprised the largest proportion of the phytoplankton population in late August samples, and in October samples, chlorophytes were the dominant taxa.

The three study reservoirs receive non-point sources of runoff from anthropogenic disturbances in the tributary basins. In the case of Prairie Lee Lake Basin, residential construction from continuing urbanization has contributed to high sediment deposition in the reservoir. Results indicate that suspended solids and nutrient concentrations in Prairie Lee Lake inflows are substantially greater than those for Prairie Lee Lake outflows. Prairie Lee Lake can be a settling basin for stormwater runoff entering Lake Jacomo, but this function is limited by the low retention time of the reservoir - a factor that is continuously decreasing because the capacity of the reservoir is decreasing. Sediment, nutrients, and pesticides enter Harrisonville City Lake largely because of agricultural practices. Whereas nutrient loads may not pose a large threat to the water quality in this reservoir at this time (1994), 
sediment deposition and pesticide concentrations, primarily herbicides, are threatening the effective uses of this reservoir.

\section{REFERENCES CITED}

Britton, L.J., and Greeson, P.E., eds., 1987, Methods for collection and analysis of aquatic biological and microbiological saniples: U.S. Geological Survey Techniques of Water-Resources Investigations, book 5, chap. A4, $363 \mathrm{p}$.

Buckner, V.L., 1976, Population dynamics of total coliform, fecal coliform, and fecal streptococcal bacteria and their relationships to selected environmental factors in Lake Jacomo, Prairie Lee Lake, and influent streams, 1972-1973: University of Missouri-Kansas City, unpublished M.S. thesis, $81 \mathrm{p}$.

Bush, R.M., and Welch, E.B., 1972, Plankton associations and related factors in a hypereutrophic lake: Water, Air, and Soil Pollution, v. 1, p. 257-274.

Carlson, R.E., 1977, A trophic-state index for lakes: Limnology and Oceanography, v. 22, no. 2, p. 361-369.

Cooke, G.D., McComas, M.R., Waller, D.W., and Kennedy, R.H., 1977, The occurrence of internal phosphorus loading in two small, eutrophic, glacial lakes in northeastern Ohio: Hydrobiologia, v. 56, p. 129-135.

Edmondson, W.T., ed., 1959, Freshwater biology: New York, John Wiley and Sons, 1,248 p.

Field, S.J., and Duerk, M.D., 1988, Hydrology and water quality of Delevan Lake in southeastern Wisconsin: U.S. Geological Survey Water-Resources Investigations Report 87-4168, $107 \mathrm{p}$.

Fishman, M.J., and Friedman, L.C., eds., 1989, Methods for determination of inorganic substances in water and fluvial sediments: U.S. Geological Survey Techniques of Water-Resources Investigations, book 5, chap. A1, $545 \mathrm{p}$.

Gerbert, W.A., Graczyk, D.A., and Krug, W.R., 1989, Average annual runoff in the United States, 1951-1980: U.S. Geological Survey Hydrologic Investigations Atlas HA-710, 1 sheet.

Guy, H.P., 1969, Laboratory theory and methods for sediment analysis: U.S. Geological Survey Techniques of Water-Resources Investigations, book 5, chap. C1, $58 \mathrm{p}$.

Guy, H.P., and Norman, V.W., 1970, Field methods for measurement of fluvial sediment: U.S. Geological Survey Techniques of Water-Resources Investigations, book 3, chap. C2, $59 \mathrm{p}$.

Hasan, S.E., Moberly, R.L., Caoile, J.A., 1988, Geology of greater Kansas City, Missouri and Kansas, United States of America: Bulletin of the Association of Engineering Geologists, v. 25, no. 3, p. 281-337.
Helsel, D.R., and Hirsch, R.M., 1992, Statistical methods in water resources: New York, Elsevier Science Publishing Co., 522 p.

Hem, J.D., 1985, Study and interpretation of the chemical characteristics of natural water ( $3 \mathrm{~d}$ ed.): U. S. Geological Survey Water-Supply Paper 2254, 263 p.

Holdren, G.C., and Armstrong, D.E., 1980, Factors affecting phosphorus release from intact lake sediment cores: Environmental Science and Technology, v. 14, p. 79-87.

Hutchinson, G.E., 1957, A treatise on limnology-Volume I, in Chemistry of Lakes: New York, John Wiley and Sons, Inc., 496 p.

Jones, J.R., and Knowlton, M.F., 1993, Limnology of Missouri reservoirs-An analysis of regional patterns: Lake Reservoir Management, v. 8, no. 1, p. 17-30.

Kansas City Star, 1944, Fish frolic in safety: Kansas City, Mo., p. 1.

Kortmann, R.W., Henry, D.D., Kuether, A., and Kaufmann, S., 1982, Epilimnetic nutrient loading by metalimnetic erosion and resultant algas responses in lake Waramaug, Connecticut: Hydrobiologia, v. 91, p. 501-510.

Larsen, D.P., Schults, D.W., and Malueg, D.W., 1981, Summer internal phosphorus supplies in Shagawa Lake, Minnesota: Limnology and Oceanography, v. 26, p. 740-753.

Missouri Department of Natural Resources, 1992, Missouri water-quality standards-Chapter 7, Water quality: Jefferson City, Clean Water Commission, 100 p.

Montgomery, J.H., 1993, Agrochemicals desk reference, environmental data: Chelsea, Mich., Lewis Publishers, $625 \mathrm{p}$.

Mortimer, C.H., 1941, The exchange of dissolved substances between mud and water in lakes, session I and II: Journal of Ecology, v. 29, p. 280-329.

-1942 , The exchange of dissolved substances between mud and water in lakes, session III and IV: Journal of Ecology, v. 30, p. 147-201.

1974, Lake hydrodynamics: Verhandlung Internationale Vereinigung Limnologie, v. 20, p. 124-197.

National Atmospheric Deposition Program (NRSP-3)/ National Trends Network, 1993, NADP/NTN Coordination Office, Natural Resources Ecology Laboratory, Colorado State University, Fort Collins, Co.

Nelson, P.W., 1987, The terrestrial natural communities of Missouri: Jefferson City, Missouri Natural Areas Committee, $197 \mathrm{p}$.

Nurnberg, G.K., and Peters, R.H., 1984, The importance of internal phosphorus load to the eutrophication of lakes with anoxic hypolimnia: Verhandlung Internationale Vereinigung Limnologie, v. 22, p. 190-194.

Ott, R.L., 1993, An introduction to statistical methods and data analysis: Belmont, $\mathrm{Ca}$., Wadsworth Publishing Company, $1,051 \mathrm{p}$. 
Preston, G.D., 1984, Soil survey of Jackson County, Missouri: Natural Resources Conservation Service, U.S. Department of Agriculture, $143 \mathrm{p}$.

Rausch, D.L., and Heinemann, H.G., 1968, Reservoir sedimentation survey methods: Columbia, University of Missouri, Agricultural Experiment Station Research Bulletin 939, 20 p.

Reckhow, K.H., 1979, Quantitative techniques for the assessment of lake quality: Washington, D.C., U.S. Environmental Protection Agency EPA-440/5-79-015, $146 \mathrm{p}$.

Rodhe, W., Vollenweider, R.A., and Nauwerck, A., 1958, The primary production and standing stock of phytoplankton, in Buzzati-Travevso, A.A., Perspectives in Marine Biology: Berkeley, University of California Press, p. 299-322.

Shapiro, J., 1973, Blue-green algae-Why they become dominant: Science, v. 179, p. 382-384.

Simmons, G.T., 1985, Soil survey of Cass County, Missouri: Natural Resources Conservation Service, U.S. Department of Agriculture, $117 \mathrm{p}$.

Stauffer, R.E., and Lee, G.F., 1973, The role of thermocline migration in regulating algal blooms, in Middlebrooks, E.J., Flkenborg, D.H., and Maloney, T.E., eds., Modeling the Eutrophication Process: Ann Arbor, Mich., Science Publications, p. 73-82.

Theis, T.L., and McCabe, P.J., 1978, Phosphorus dynanics in hypereutrophic lake sediments: Water Research Bulletin, v. 12, no. 9, p. 667-685.

Thurman, E.M., Goolsby, D.A., Moyor, M.T., and Kolpin, D.W., 1991, Herbicides in surface water of the midwestern United States-The effect of the spring flush:
Journal of Environmental Science and Technology 1, v. 25 , no. 10 , p. 1,794-1,796.

Thurman, E.M., Moyor, M.T., Pomes, M.L., Perry, C.A., and Schwab, A.P., 1990, Enzyme-linked immunosorbent assay compared with gas chromatography/mass spectrometry for the determination of triazine herbicides in water: Analytical Chemistry, v. 62, no. 18, p. 2,043-2,048.

U.S. Environmental Protection Agency, 1988, Methods for determination of organic compounds in drinking water: U.S. Environmental Protection Agency Publication 600/4-88/039.

1992, Drinking water regulations and health advisories: Office of Water, $13 \mathrm{p}$.

U.S. Geological Survey, 1954-91, Water resources data, Missouri: U.S. Geological Survey Water-Data Report, published annually.

U.S. Geological Survey and Missouri Division of Geology and Land Survey, 1967, Mineral and water resources of Missouri: 90th Congress, 1st session, Senate Document 19, 399 p.; also Rolla, Missouri Division of Geology and Land Survey, v. 43, 2d ser., 399 p.

Ward, J.R., and Harr, C.A., eds., 1990, Methods for collection and processing of surface-water and bed-material saniples for physical and chemical analyses: U.S. Geological Survey Open-File Report 90-140, 71 p.

Wershaw, R.L., Fishman, M.J., Grabbe, R.R., and Lowe, L.E., eds., 1987, Methods for the determination of organic substances in water and fluvial sediment: U.S. Geological Survey Techniques of Water-Resources Investigations, book 5, chap. A3, $80 \mathrm{p}$.

Wetzel, R.G., 1983, Limnology (2d ed.): New York, Saunders College Publishing, $767 \mathrm{p}$. 
TABLES 
Table 9. Summary statistics of selected physical properties and chemical constituents from three reservoirs in westcentral Missouri

[ $\mu \mathrm{S} / \mathrm{cm}$, microsiemens per centimeter at 25 degrees Celsius; $\mathrm{mg} / \mathrm{L}$, milligrams per liter, $\mathrm{CaCO}_{3}$, calcium carbonate; <, less than]

\begin{tabular}{|c|c|c|c|c|}
\hline $\begin{array}{l}\text { Physical property } \\
\text { or constituent }\end{array}$ & $\begin{array}{l}\text { Number } \\
\text { of samples }\end{array}$ & Maximum & Minimum & Median \\
\hline \multicolumn{5}{|c|}{ Prairie Lee Lake--Site PLI (east arm at surface) } \\
\hline Specific conductance $(\mu \mathrm{S} / \mathrm{cm})$ & 16 & 463 & 332 & 352 \\
\hline $\mathrm{pH}$ & 16 & 8.9 & 7.4 & 8.2 \\
\hline Alkalinity, total $\left(\mathrm{mg} / \mathrm{L}\right.$ as $\left.\mathrm{CaCO}_{3}\right)$ & 16 & 136 & 100 & 114 \\
\hline Organic nitrogen, total (mg/L) & 13 & .90 & .28 & .45 \\
\hline Ammonia as nitrogen, total $(\mathrm{mg} / \mathrm{L})$ & 16 & .13 & $<.01$ & .03 \\
\hline Nitrate as nitrogen, total (mg/L) & 15 & .76 & $<.05$ & .20 \\
\hline Phosphorus, total (mg/L) & 16 & .05 & $<.01$ & .03 \\
\hline Orthophosphate as phosphorus, total (mg/L) & 16 & .02 & $<.01$ & .01 \\
\hline \multicolumn{5}{|c|}{ Prairie Lee Lake--Site PL1 (east arm at bottom) } \\
\hline Specific conductance $(\mu \mathrm{S} / \mathrm{cm})$ & 16 & 463 & 312 & 367 \\
\hline $\mathrm{pH}$ & 16 & 8.2 & 7.4 & 7.8 \\
\hline Alkalinity, total (mg/L as $\mathrm{CaCO}_{3}$ ) & 16 & 136 & 98 & 118 \\
\hline Organic nitrogen, total (mg/L) & 15 & 1.2 & .32 & .58 \\
\hline Ammonia as nitrogen, total $(\mathrm{mg} / \mathrm{L})$ & 16 & .43 & $<.01$ & .08 \\
\hline Nitrate as nitrogen, total $(\mathrm{mg} / \mathrm{L})$ & 16 & 1.0 & $<.05$ & .34 \\
\hline Phosphorus, total (mg/L) & 16 & .06 & $<.01$ & .04 \\
\hline Orthophosphate as phosphorus, total (mg/L) & 16 & .06 & $<.01$ & .01 \\
\hline
\end{tabular}

Prairie Lee Lake--Site PL2 (near dam at surface)

Specific conductance $(\mu \mathrm{S} / \mathrm{cm})$

$\mathrm{pH}$

Alkalinity, total $\left(\mathrm{mg} / \mathrm{L}\right.$ as $\left.\mathrm{CaCO}_{3}\right)$

Organic nitrogen, total $(\mathrm{mg} / \mathrm{L})$

Ammonia as nitrogen, total $(\mathrm{mg} / \mathrm{L})$

Nitrate as nitrogen, total $(\mathrm{mg} / \mathrm{L})$

Phosphorus, total (mg/L)

Orthophosphate as phosphorus, total $(\mathrm{mg} / \mathrm{L})$
17

17

17

12

15

15

15

15
458

9.0

134

.97

.13

.92

.04

.02
334

7.1

97

.28

$<.01$

$<.05$

$<.01$

$<.01$
358

8.2

117 
Table 9. Summary statistics of selected physical properties and chemical constituents from three reservoirs in westcentral Missouri--Continued

\begin{tabular}{lcccc}
\hline \multicolumn{1}{c}{$\begin{array}{c}\text { Physical property } \\
\text { or constituent }\end{array}$} & $\begin{array}{c}\text { Number } \\
\text { of samples }\end{array}$ & Maximum & Minimum & Median \\
\hline Specific conductance $(\mu \mathrm{S} / \mathrm{cm})$ & Prairie Lee Lake--Site PL2 (near dam at bottom) & & \\
$\mathrm{pH}$ & 17 & 459 & 340 & 406 \\
Alkalinity, total $\left(\mathrm{mg} / \mathrm{L}\right.$ as $\left.\mathrm{CaCO}_{3}\right)$ & 17 & 8.5 & 7.1 & 7.5 \\
Organic nitrogen, total $(\mathrm{mg} / \mathrm{L})$ & 17 & 159 & 117 & 134 \\
Ammonia as nitrogen, total $(\mathrm{mg} / \mathrm{L})$ & 15 & .80 & .27 & .59 \\
Nitrate as nitrogen, total $(\mathrm{mg} / \mathrm{L})$ & 15 & 2.1 & .01 & .43 \\
Phosphorus, total $(\mathrm{mg} / \mathrm{L})$ & 15 & .92 & $<.05$ & .21 \\
Orthophosphate as phosphorus, total $(\mathrm{mg} / \mathrm{L})$ & 15 & .17 & .02 & .05
\end{tabular}

Prairie Lee Lake--Site PL3 (west arm at surface)

Specific conductance $(\mu \mathrm{S} / \mathrm{cm})$

$\mathrm{pH}$

Alkalinity, total $\left(\mathrm{mg} / \mathrm{L}\right.$ as $\left.\mathrm{CaCO}_{3}\right)$

Organic nitrogen, total $(\mathrm{mg} / \mathrm{L})$

Ammonia as nitrogen, total $(\mathrm{mg} / \mathrm{L})$

Nitrate as nitrogen, total $(\mathrm{mg} / \mathrm{L})$

Phosphorus, total (mg/L)

Orthophosphate as phosphorus, total (mg/L)
16

16

16

13

16

16

16

16
460

8.9

150

1.4

.13

.90

.04

.02
334

7.3

96

.37

$<.01$

$<.05$

.01

$<.01$
374

8.3

116

.46

.02

.28

.03

.01

Prairie Lee Lake--Site PL3 (west arm at bottom)

Specific conductance $(\mu \mathrm{S} / \mathrm{cm})$

$\mathrm{pH}$

Alkalinity, total $\left(\mathrm{mg} / \mathrm{L}\right.$ as $\left.\mathrm{CaCO}_{3}\right)$

Organic nitrogen, total (mg/L)

Ammonia as nitrogen, total $(\mathrm{mg} / \mathrm{L})$

Nitrate as nitrogen, total $(\mathrm{mg} / \mathrm{L})$

Phosphorus, total (mg/L)

Orthophosphate as phosphorus, total (mg/L)
15

16

16

16

16

16

16

16
469

8.1

136

.87

.96

.89

.10

.05
333

7.3

392

7.6

114

.28

.47

.16

.39

.05

.02 
Table 9. Summary statistics of selected physical properties and chemical constituents from three reservoirs in westcentral Missouri-Continued

\begin{tabular}{|c|c|c|c|c|}
\hline $\begin{array}{l}\text { Physical property } \\
\text { or constltuent }\end{array}$ & $\begin{array}{l}\text { Number } \\
\text { of samples }\end{array}$ & Maximum & Minimum & Medlan \\
\hline \multicolumn{5}{|c|}{ Lake Jacomo--Site LJ1 (south site at surface) } \\
\hline Specific conductance $(\mu \mathrm{S} / \mathrm{cm})$ & 17 & 372 & 311 & 329 \\
\hline $\mathrm{pH}$ & 17 & 8.5 & 7.9 & 8.2 \\
\hline Alkalinity, total ( $\mathrm{mg} / \mathrm{L}$ as $\left.\mathrm{CaCO}_{3}\right)$ & 17 & 130 & 112 & 121 \\
\hline Organic nitrogen, total $(\mathrm{mg} / \mathrm{L})$ & 11 & .76 & .24 & .49 \\
\hline Ammonia as nitrogen, total $(\mathrm{mg} / \mathrm{L})$ & 16 & .11 & $<.01$ & .02 \\
\hline Nitrate as nitrogen, total (mg/L) & 16 & .08 & $<.05$ & $<.05$ \\
\hline Phosphorus, total (mg/L) & 16 & .05 & $<.01$ & .03 \\
\hline Orthophosphate as phosphorus, tota & 16 & .02 & $<.01$ & .01 \\
\hline
\end{tabular}

Lake Jacomo--Site LJ1 (south site at bottom)

Specific conductance $(\mu \mathrm{S} / \mathrm{cm})$

$\mathrm{pH}$

Alkalinity, total $\left(\mathrm{mg} / \mathrm{L}\right.$ as $\left.\mathrm{CaCO}_{3}\right)$

Organic nitrogen, total (mg/L)

Ammonia as nitrogen, total $(\mathrm{mg} / \mathrm{L})$

Nitrate as nitrogen, total $(\mathrm{mg} / \mathrm{L})$

Phosphorus, total (mg/L)

Orthophosphate as phosphorus, total $(\mathrm{mg} / \mathrm{L})$
16

17

17

14

15

15

15

15
368

8.5

132

1.1

.13

.12

.07

.03

Lake Jacomo--Site Lل2 (centrai site at surface)

Specific conductance $(\mu \mathrm{S} / \mathrm{cm})$

$\mathrm{pH}$

Alkalinity, total (mg/L as $\left.\mathrm{CaCO}_{3}\right)$

Organic nitrogen, total (mg/L)

Ammonia as nitrogen, total $(\mathrm{mg} / \mathrm{L})$

Nitrate as nitrogen, total $(\mathrm{mg} / \mathrm{L})$

Phosphorus, total (mg/L)

Orthophosphate as phosphorus, total (mg/L)
16

16

16

13

16

16

16

16
359

8.8

131

1.1

.10

.08

.04

.03
314

7.6

115

.32

$<.01$

$<.05$

$<.01$

$<.01$

8.1

121

\section{.48}

.03

$<.05$

.04

.01 
Table 9. Summary statistics of selected physical properties and chemical constituents from three reservoirs in westcentral Missouri--Continued

\begin{tabular}{lcccc}
\hline \multicolumn{1}{c}{$\begin{array}{c}\text { Physical property } \\
\text { or constituent }\end{array}$} & $\begin{array}{c}\text { Number } \\
\text { of sampies }\end{array}$ & Maximum & Minimum & Median \\
\hline Specific conductance $(\mu \mathrm{S} / \mathrm{cm})$ & Lake Jacomo--Site $\mathbf{L J 2}$ (central site at bottom) & & \\
$\mathrm{pH}$ & 15 & 373 & 326 & 345 \\
Alkalinity, total $\left(\mathrm{mg} / \mathrm{L}\right.$ as $\left.\mathrm{CaCO}_{3}\right)$ & 16 & 8.4 & 7.5 & 7.9 \\
Organic nitrogen, total $(\mathrm{mg} / \mathrm{L})$ & 16 & 160 & 120 & 128 \\
Ammonia as nitrogen, total $(\mathrm{mg} / \mathrm{L})$ & 16 & .97 & .34 & .54 \\
Nitrate as nitrogen, total $(\mathrm{mg} / \mathrm{L})$ & 16 & .62 & .01 & .06 \\
Phosphorus, total $(\mathrm{mg} / \mathrm{L})$ & 16 & .09 & $<.05$ & $<.05$ \\
Orthophosphate as phosphorus, total $(\mathrm{mg} / \mathrm{L})$ & 16 & .37 & $<.01$ & .04
\end{tabular}

Lake Jacomo--Site LJ3 (near dam at surface)

Specific conductance $(\mu \mathrm{S} / \mathrm{cm})$

$\mathrm{pH}$

Alkalinity, total $\left(\mathrm{mg} / \mathrm{L}\right.$ as $\left.\mathrm{CaCO}_{3}\right)$

Organic nitrogen, total $(\mathrm{mg} / \mathrm{L})$

Ammonia as nitrogen, total $(\mathrm{mg} / \mathrm{L})$

Nitrate as nitrogen, total $(\mathrm{mg} / \mathrm{L})$

Phosphorus, total (mg/L)

Orthophosphate as phosphorus, total $(\mathrm{mg} / \mathrm{L})$
17

17

17

11

16

16

16

16
358

8.6

129

307

7.7

8.4

103

121

.33

.49

$<.01$

.02

$<.05$

$<.05$

$<.01$

.02

$<.01$

.01

Lake Jacomo--Site $\mathbf{L J 3}$ (near dam at bottom)

Specific conductance $(\mu \mathrm{S} / \mathrm{cm})$

$\mathrm{pH}$

Alkalinity, total $\left(\mathrm{mg} / \mathrm{L}\right.$ as $\left.\mathrm{CaCO}_{3}\right)$

Organic nitrogen, total $(\mathrm{mg} / \mathrm{L})$

Ammonia as nitrogen, total (mg/L)

Nitrate as nitrogen, total $(\mathrm{mg} / \mathrm{L})$

Phosphorus, total (mg/L)

Orthophosphate as phosphorus, total $(\mathrm{mg} / \mathrm{L})$
17

17

17

14

16

16

16

16
392

8.4

170

$$
.75
$$

1.2

.19

.58

.56
320

7.5

122

.27

$<.01$

$<.05$

.01

$<.01$
351

7.7

131

.12

$<.05$

.06

.04 
Table 9. Summary statistics of selected physical properties and chemical constituents from three reservoirs in westcentral Missouri--Continued

\begin{tabular}{|c|c|c|c|c|}
\hline $\begin{array}{l}\text { Physical property } \\
\text { or constltuent }\end{array}$ & $\begin{array}{c}\text { Number } \\
\text { of samples }\end{array}$ & Maximum & MInImum & Medlan \\
\hline \multicolumn{5}{|c|}{ Harrisonville City Lake--Site HL1 (south arm at surface) } \\
\hline Specific conductance $(\mu \mathrm{S} / \mathrm{cm})$ & 12 & 300 & 255 & 278 \\
\hline $\mathrm{pH}$ & 12 & 8.7 & 7.7 & 8.2 \\
\hline Alkalinity, total $\left(\mathrm{mg} / \mathrm{L}\right.$ as $\left.\mathrm{CaCO}_{3}\right)$ & 12 & 126 & 96 & 112 \\
\hline Organic nitrogen, total (mg/L) & 7 & .62 & .39 & .49 \\
\hline Ammonia as nitrogen, total $(\mathrm{mg} / \mathrm{L})$ & 12 & .16 & $<.01$ & .05 \\
\hline Nitrate as nitrogen, total $(\mathrm{mg} / \mathrm{L})$ & 12 & 1.2 & $<.05$ & .40 \\
\hline Phosphorus, total (mg/L) & 12 & .20 & $<.01$ & .03 \\
\hline Orthophosphate as phosphorus, total (mg/L) & 12 & .12 & $<.01$ & .01 \\
\hline \multicolumn{5}{|c|}{ Harrisonville City Lake--Site HL2 (near dam at surface) } \\
\hline Specific conductance $(\mu \mathrm{S} / \mathrm{cm})$ & 17 & 304 & 256 & 287 \\
\hline $\mathrm{pH}$ & 17 & 8.7 & 7.4 & 8.0 \\
\hline Alkalinity, total $\left(\mathrm{mg} / \mathrm{L}\right.$ as $\left.\mathrm{CaCO}_{3}\right)$ & 17 & 129 & 100 & 113 \\
\hline Organic nitrogen, total $(\mathrm{mg} / \mathrm{L})$ & 11 & 1.1 & .36 & .51 \\
\hline Ammonia as nitrogen, total $(\mathrm{mg} / \mathrm{L})$ & 16 & .18 & .02 & .06 \\
\hline Nitrate as nitrogen, total (mg/L) & 16 & 4.7 & $<.05$ & .39 \\
\hline Phosphorus, total (mg/L) & 16 & .14 & $<.01$ & .04 \\
\hline Orthophosphate as phosphorus, total (mg/L) & 16 & .09 & $<.01$ & .01 \\
\hline
\end{tabular}

Harrisonville City Lake--Site HL2 (near dam at bottom)

Specific conductance $(\mu \mathrm{S} / \mathrm{cm})$

$\mathrm{pH}$

Alkalinity, total $\left(\mathrm{mg} / \mathrm{L}\right.$ as $\left.\mathrm{CaCO}_{3}\right)$

Organic nitrogen, total $(\mathrm{mg} / \mathrm{L})$

Ammonia as nitrogen, total $(\mathrm{mg} / \mathrm{L})$

Nitrate as nitrogen, total $(\mathrm{mg} / \mathrm{L})$

Phosphorus, total $(\mathrm{mg} / \mathrm{L})$

Orthophosphate as phosphorus, total (mg/L)
16

16

16

13

16

16

16

16
410

$$
8.1
$$

211

1.0

2.5

1.6

.42

.36
246

6.9

104

.07

.06

$<.05$

$<.01$

$<.01$
323

7.6

131

.56

.52

$<.05$

.07

.05 
Table 9. Summary statistics of selected physical properties and chemical constituents from three reservoirs in westcentral Missouri-Continued

\begin{tabular}{lcccc}
\hline \multicolumn{1}{c}{$\begin{array}{c}\text { Physicai property } \\
\text { or constituent }\end{array}$} & $\begin{array}{c}\text { Number } \\
\text { of samples }\end{array}$ & Maximum & Minimum & Median \\
\hline Specific conductance $(\mu \mathrm{S} / \mathrm{cm})$ & 12 & 300 & 198 & 281 \\
$\mathrm{pH}$ & 12 & 8.6 & 7.6 & 8.0 \\
Alkalinity, total $\left(\mathrm{mg} / \mathrm{L}\right.$ as $\left.\mathrm{CaCO}_{3}\right)$ & 12 & 125 & 74 & 112 \\
Organic nitrogen, total $(\mathrm{mg} / \mathrm{L})$ & 8 & .68 & .39 & .48 \\
Ammonia as nitrogen, total $(\mathrm{mg} / \mathrm{L})$ & 12 & .13 & .01 & .04 \\
Nitrate as nitrogen, total $(\mathrm{mg} / \mathrm{L})$ & 12 & 1.3 & $<.05$ & .46 \\
Phosphorus, total $(\mathrm{mg} / \mathrm{L})$ & 12 & .13 & $<.01$ & .03 \\
Orthophosphate as phosphorus, total $(\mathrm{mg} / \mathrm{L})$ & 12 & .08 & $<.01$ & .01 \\
\hline
\end{tabular}




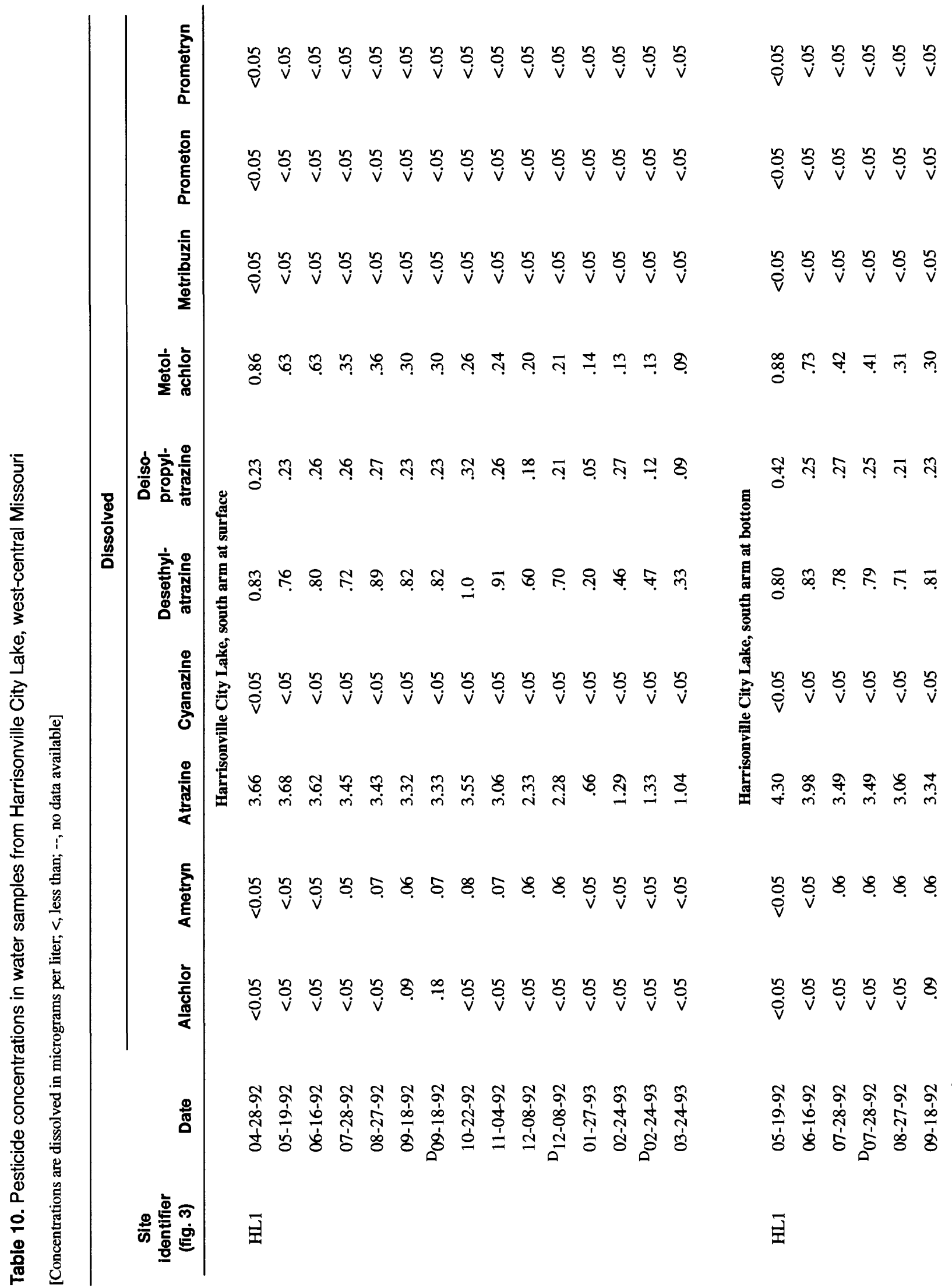




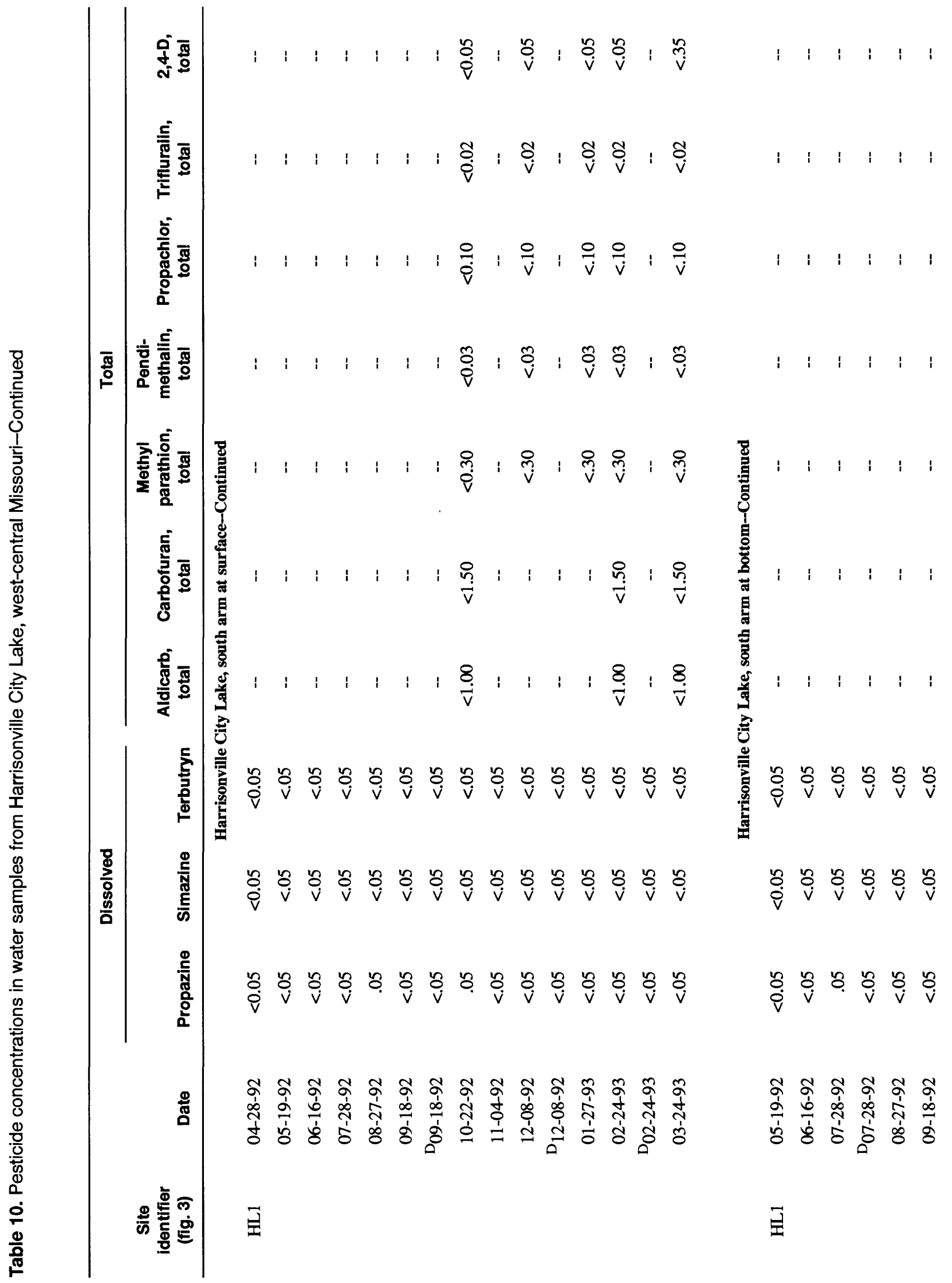




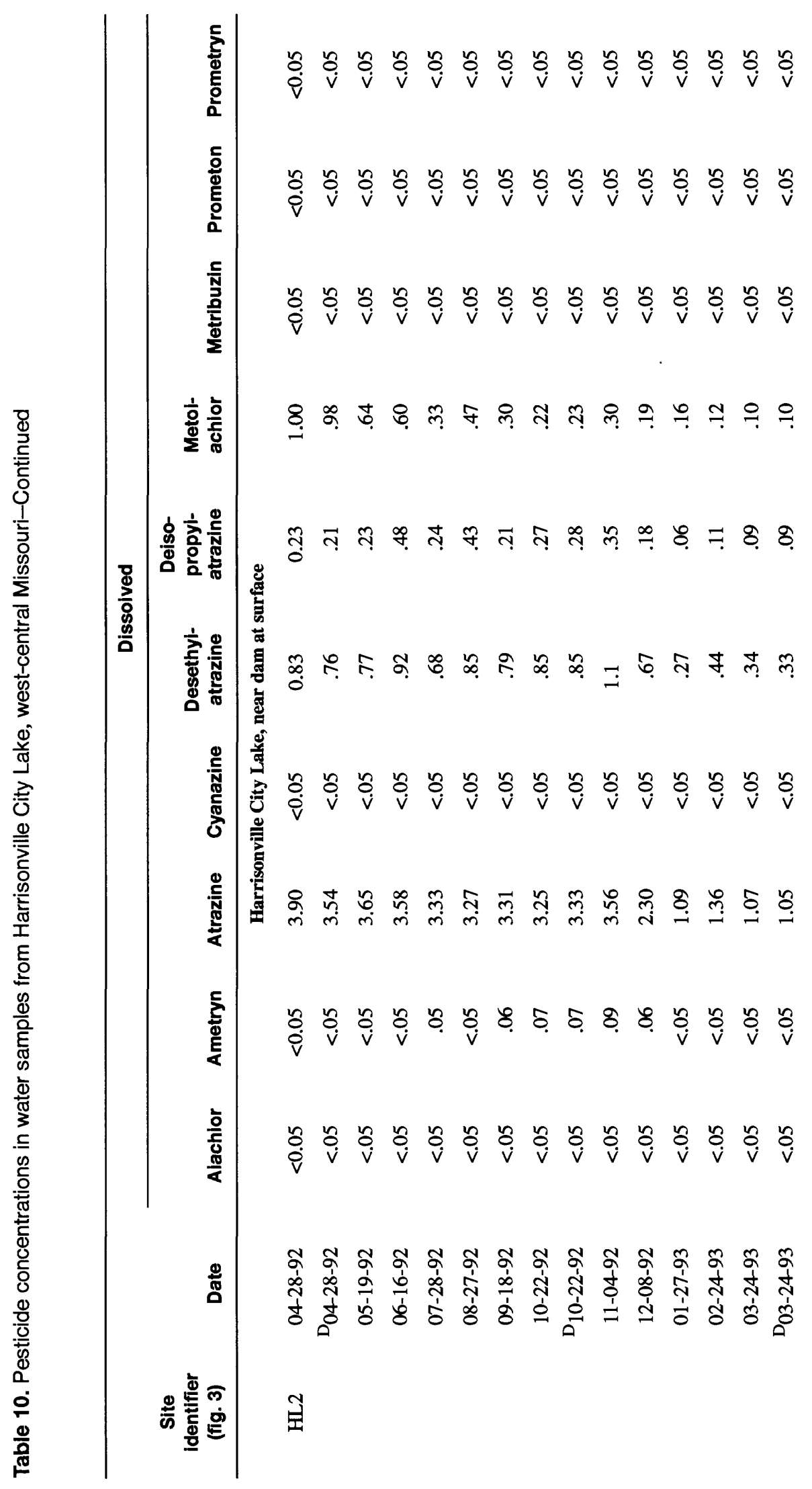




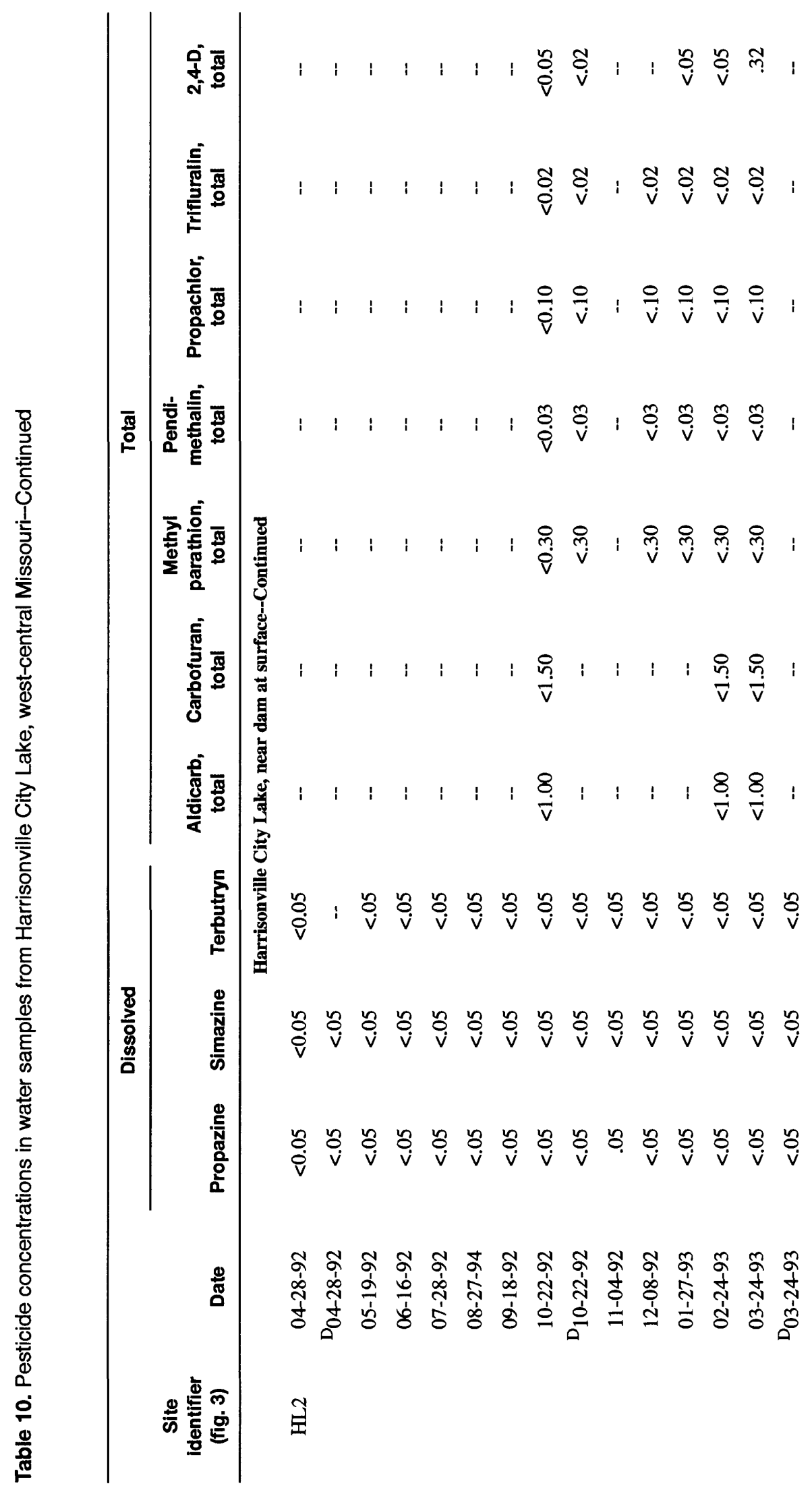




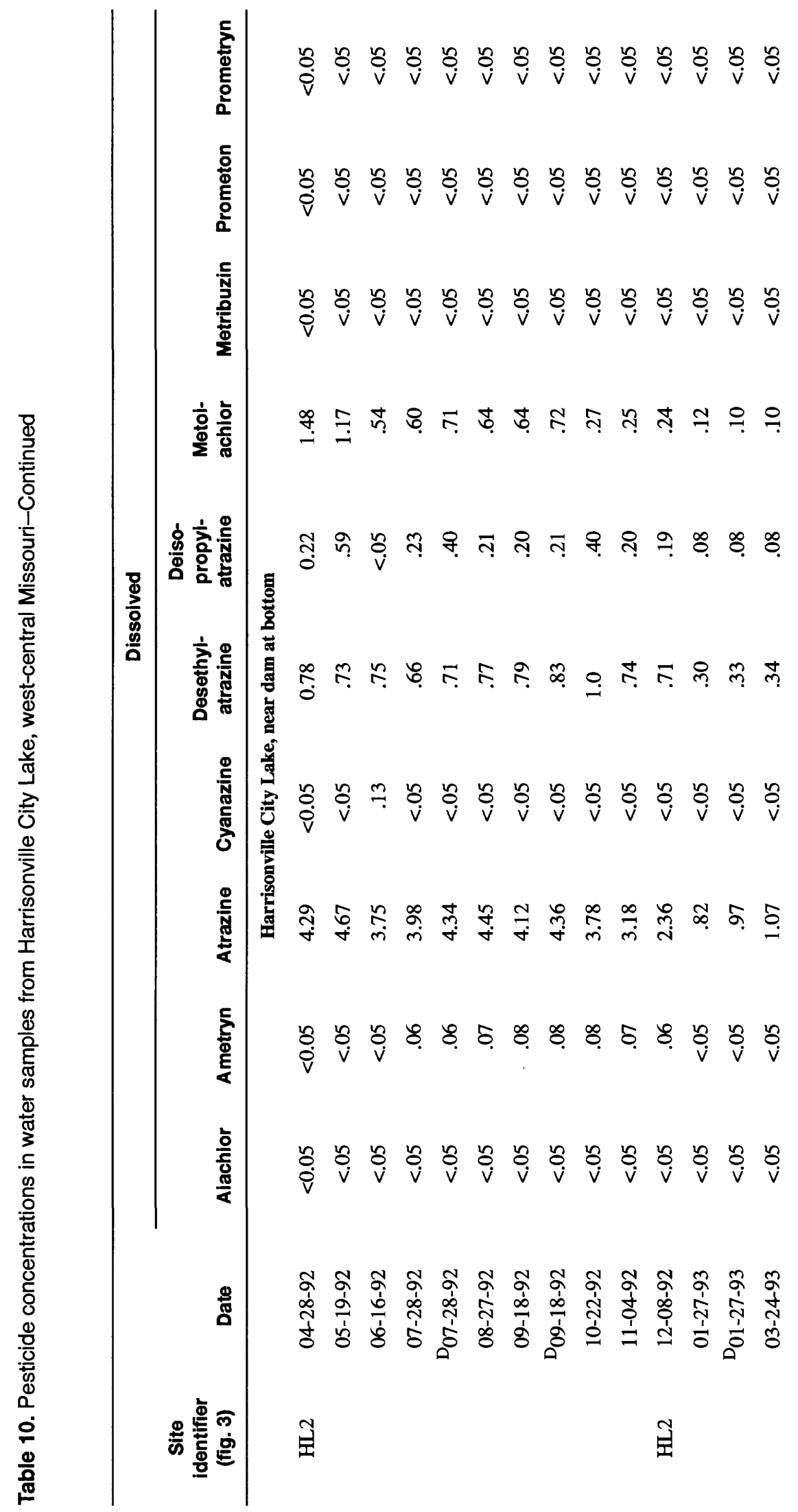




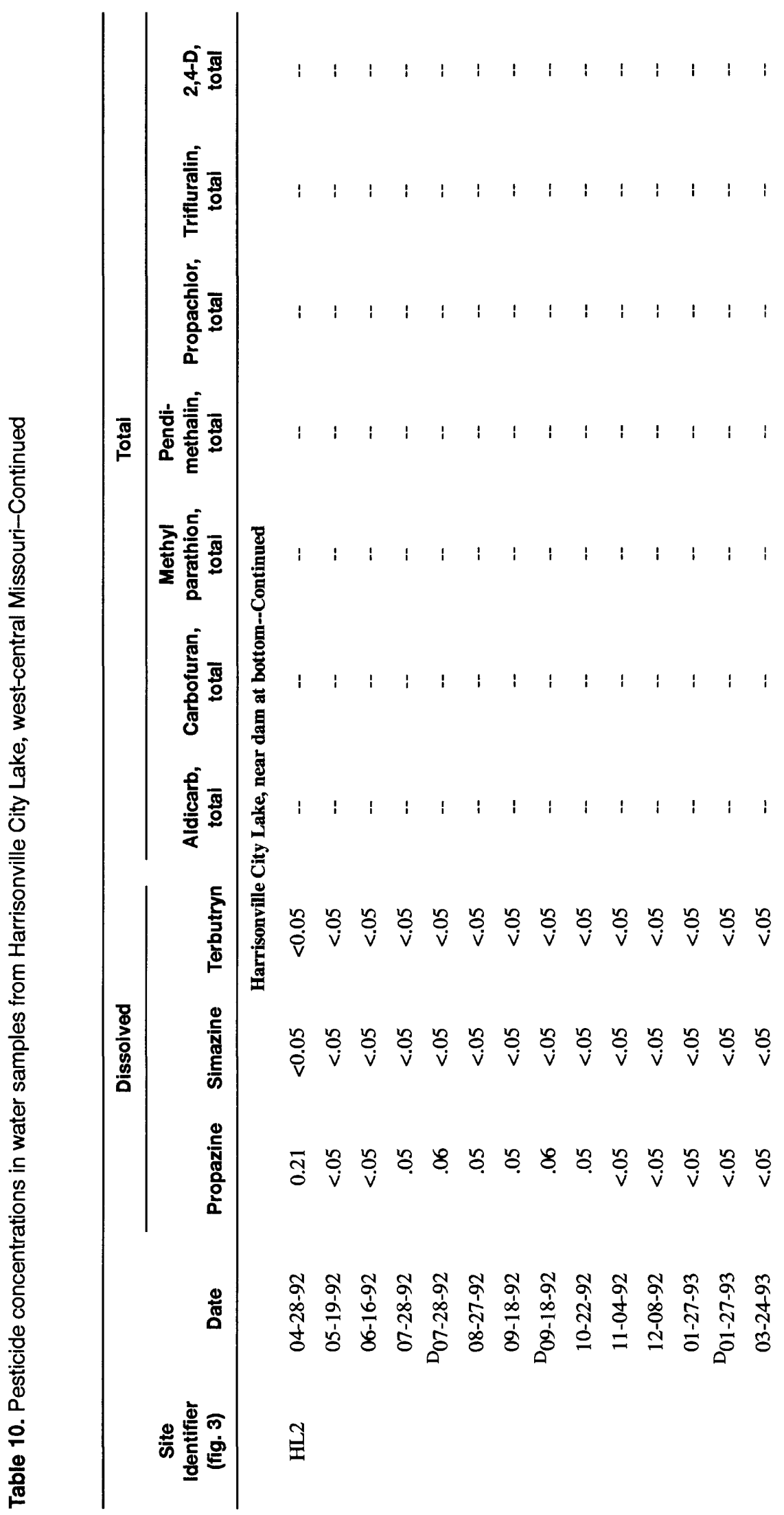




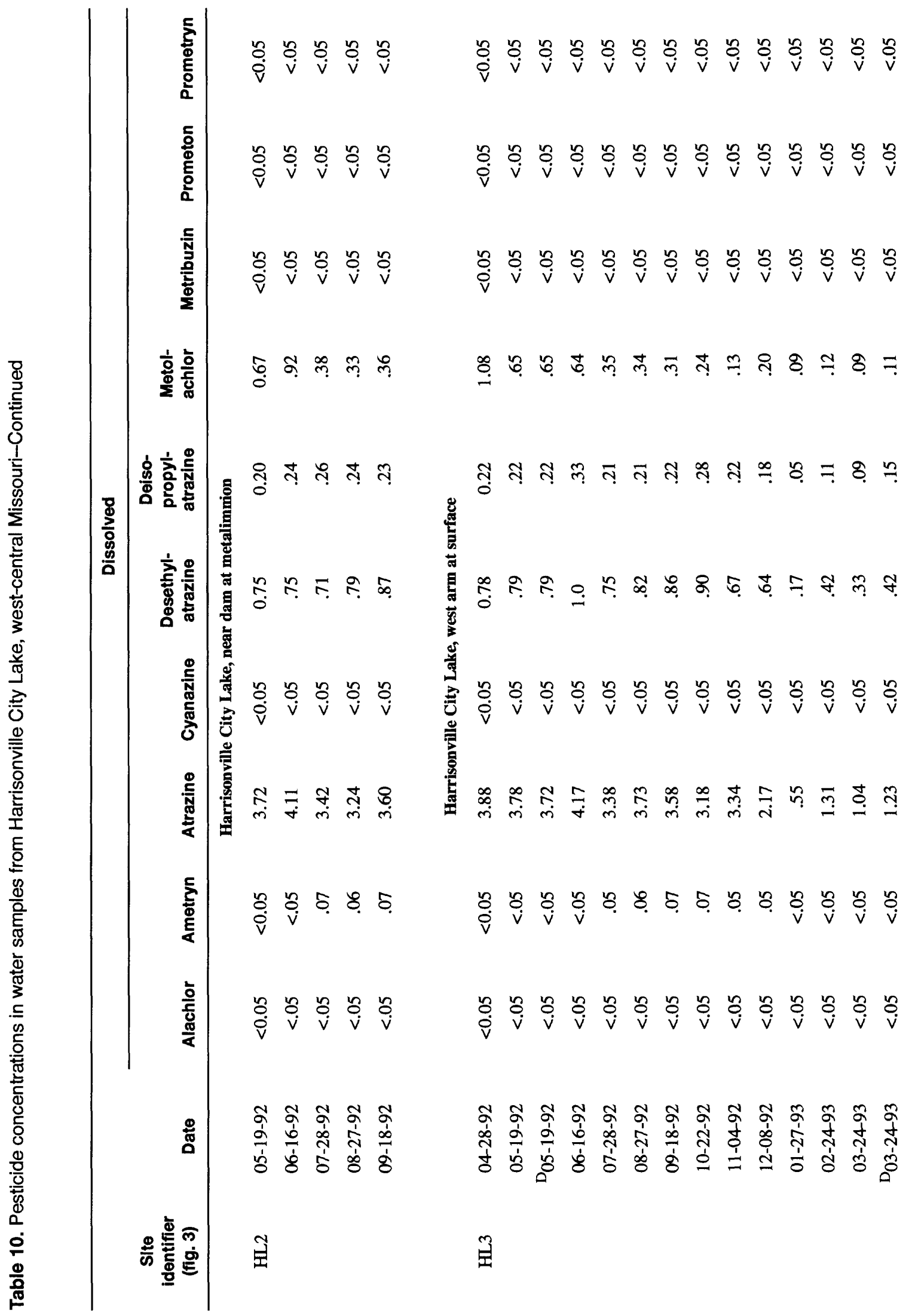




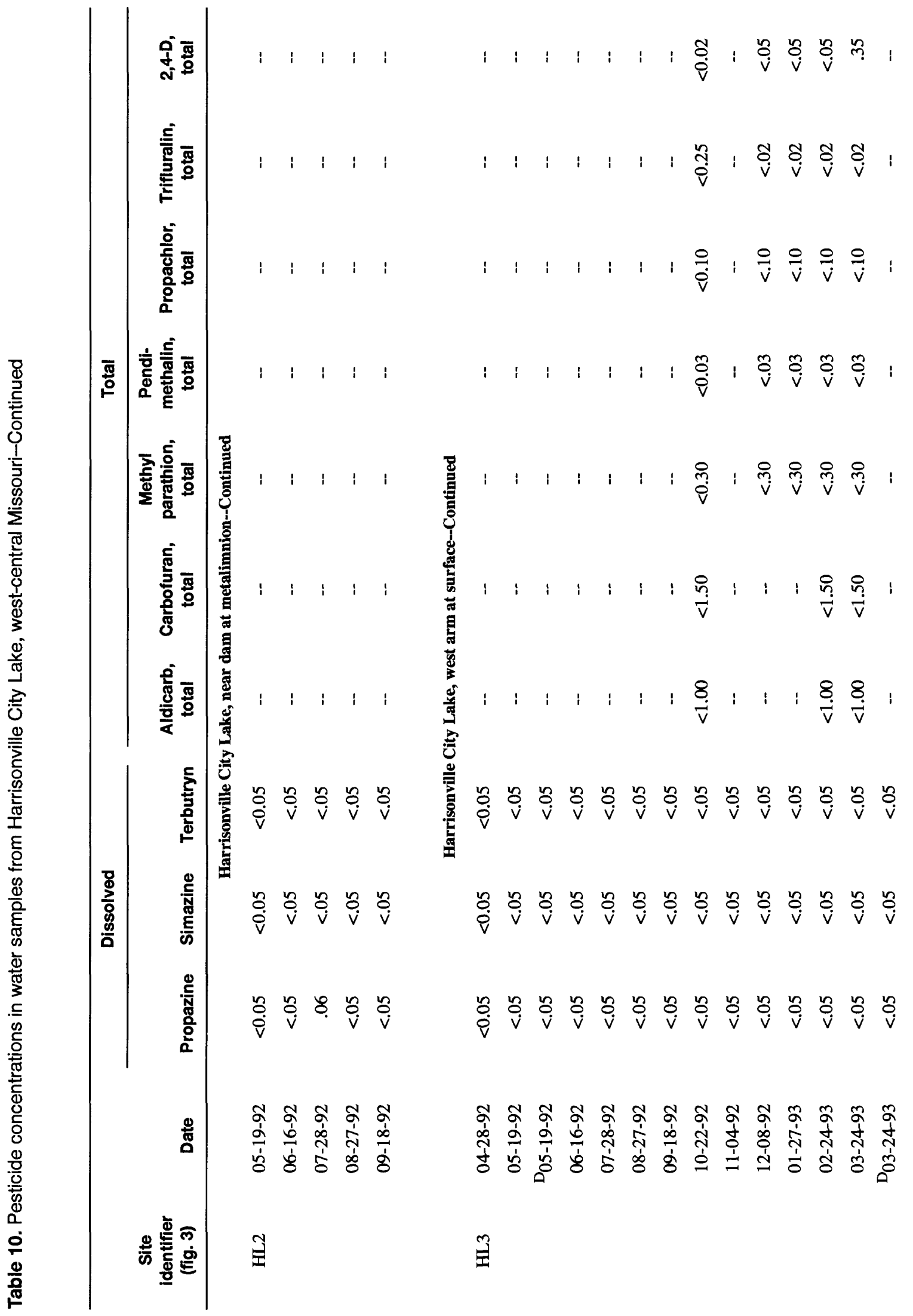




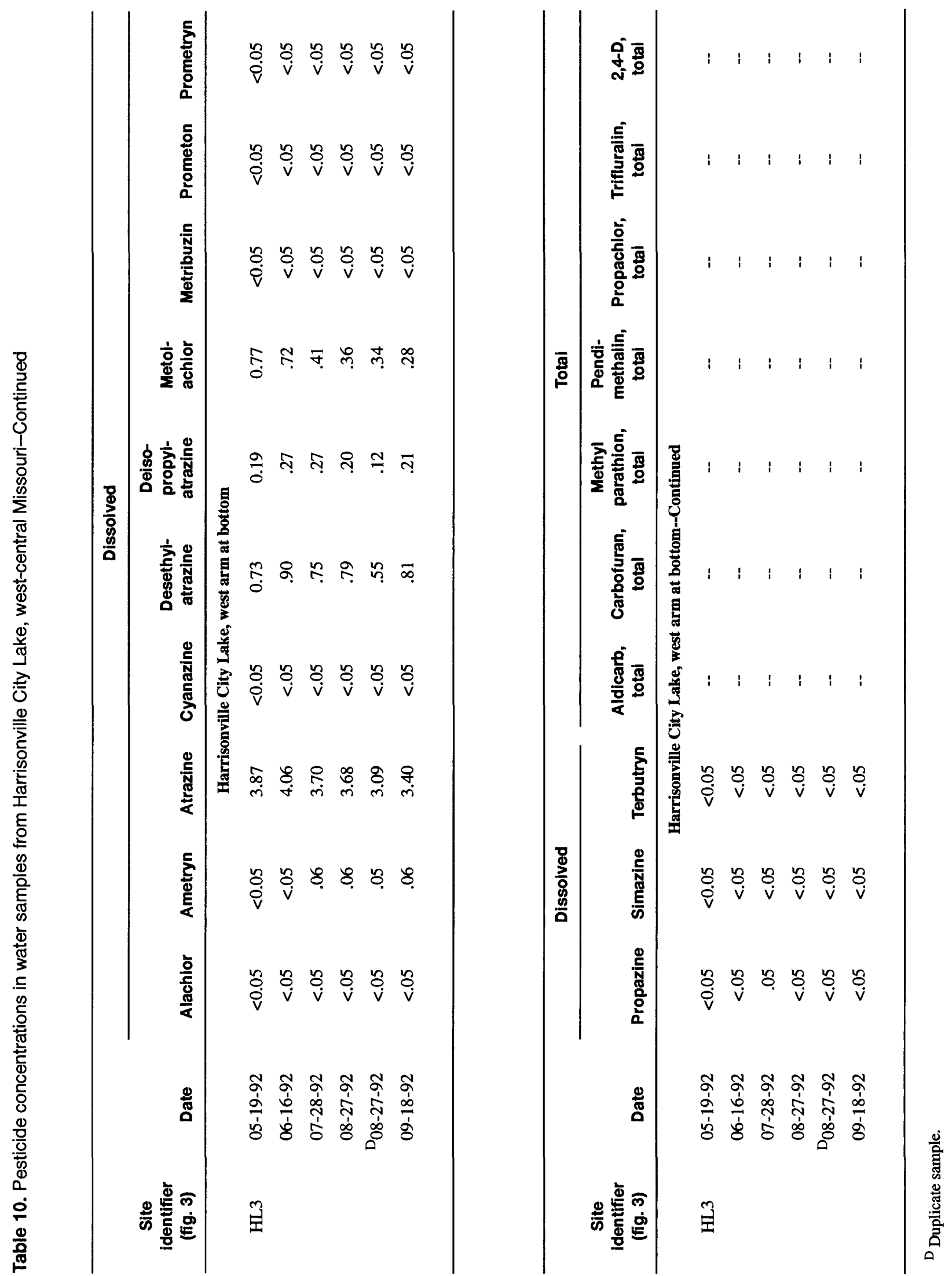




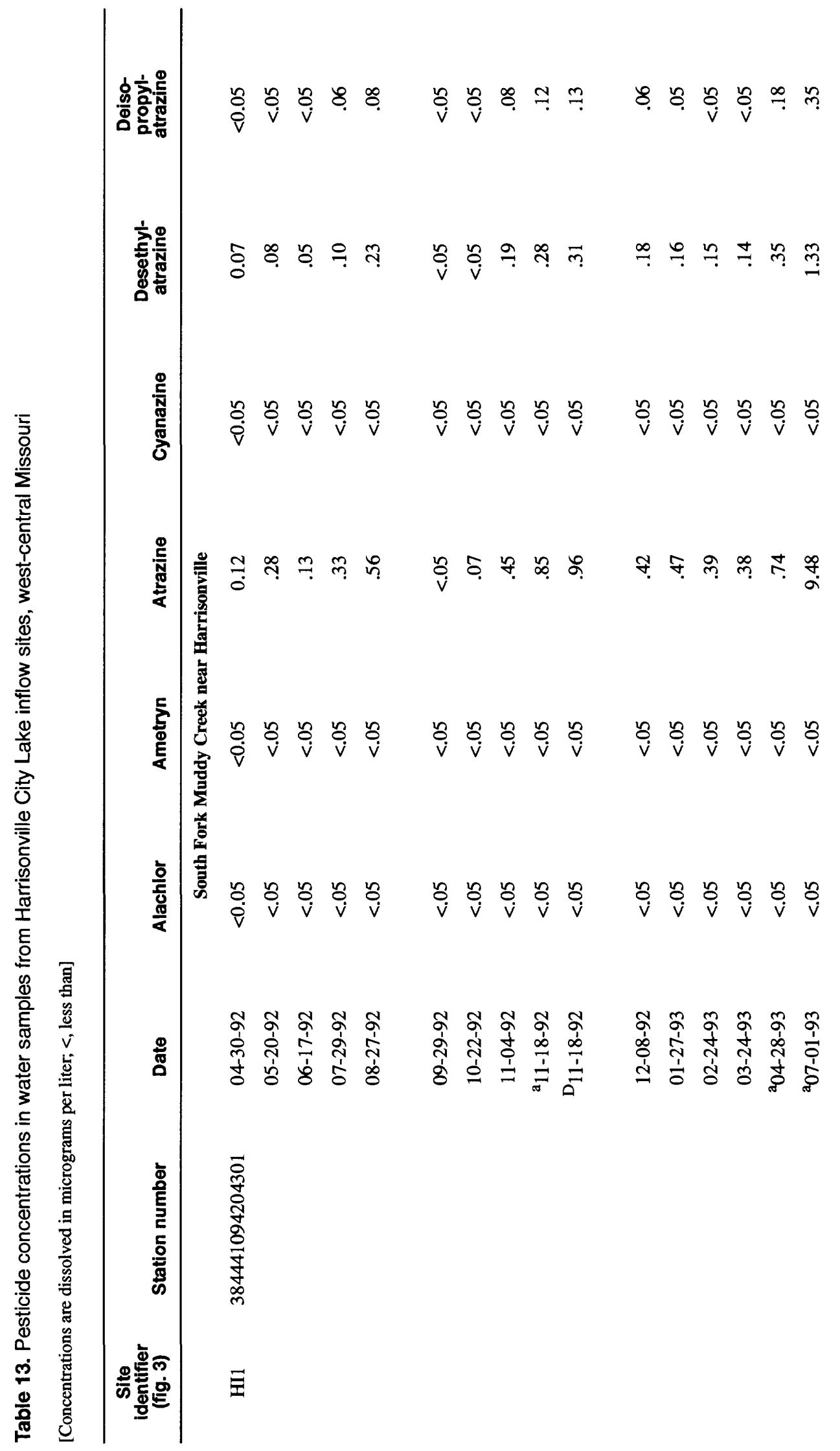




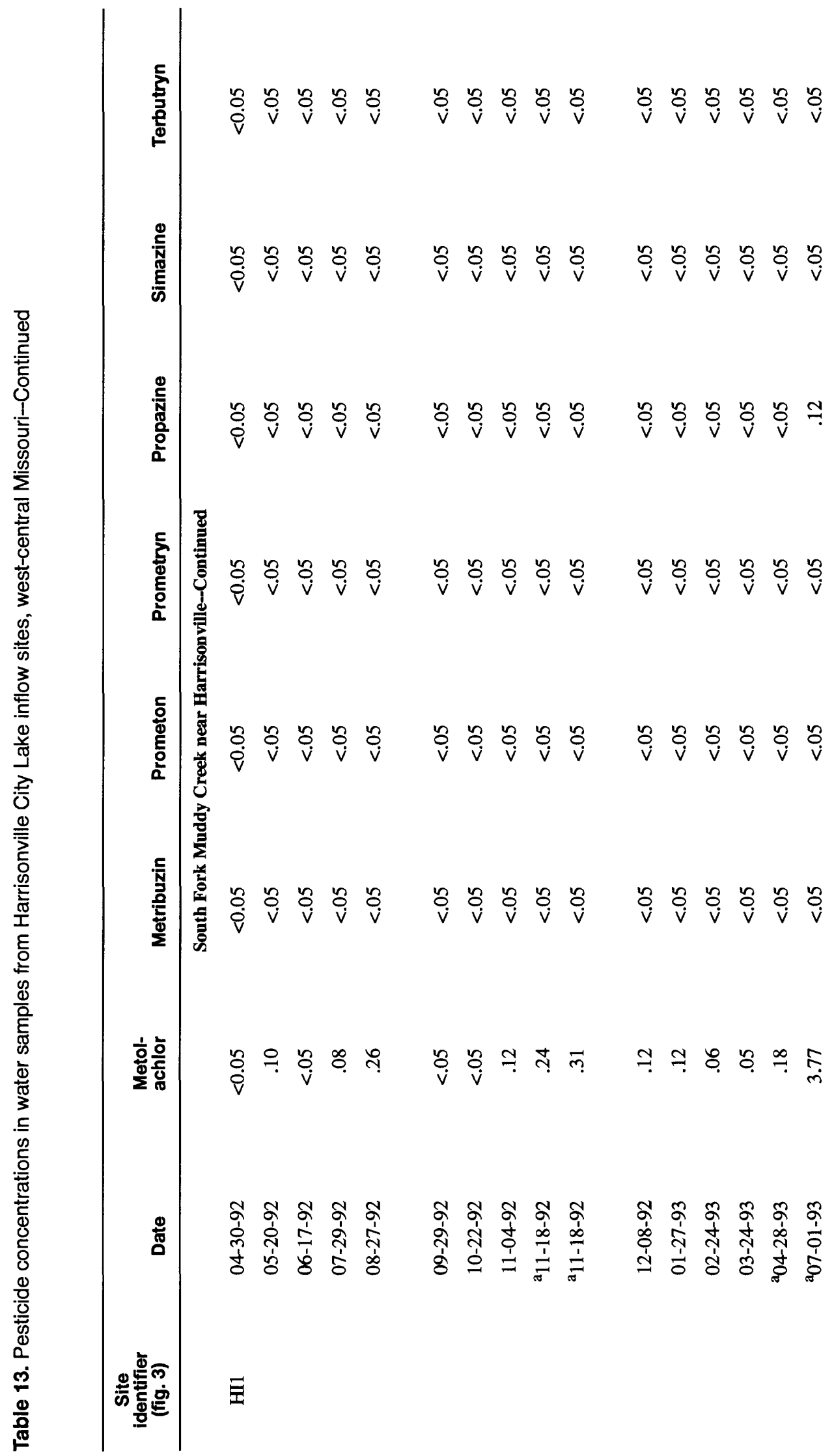




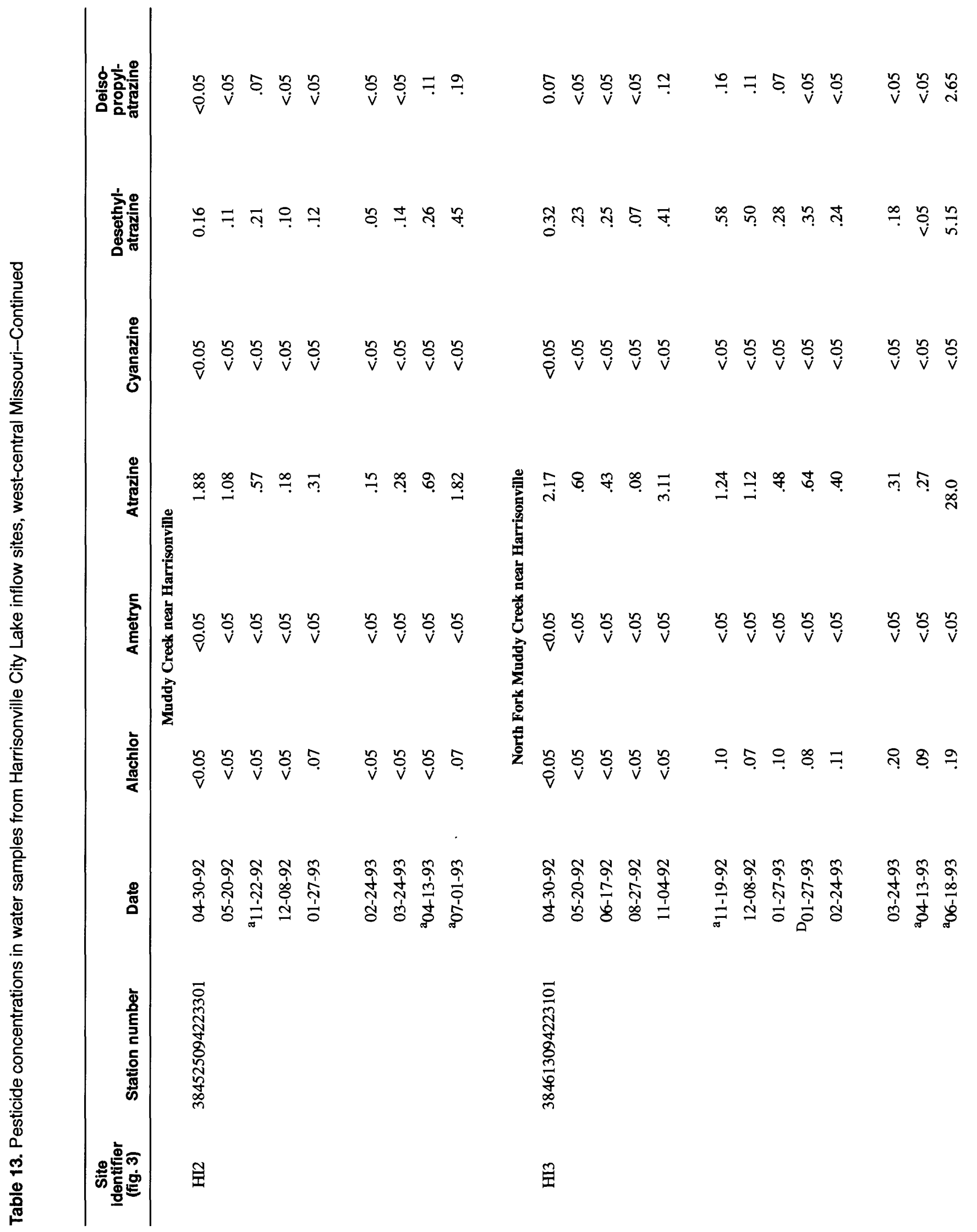



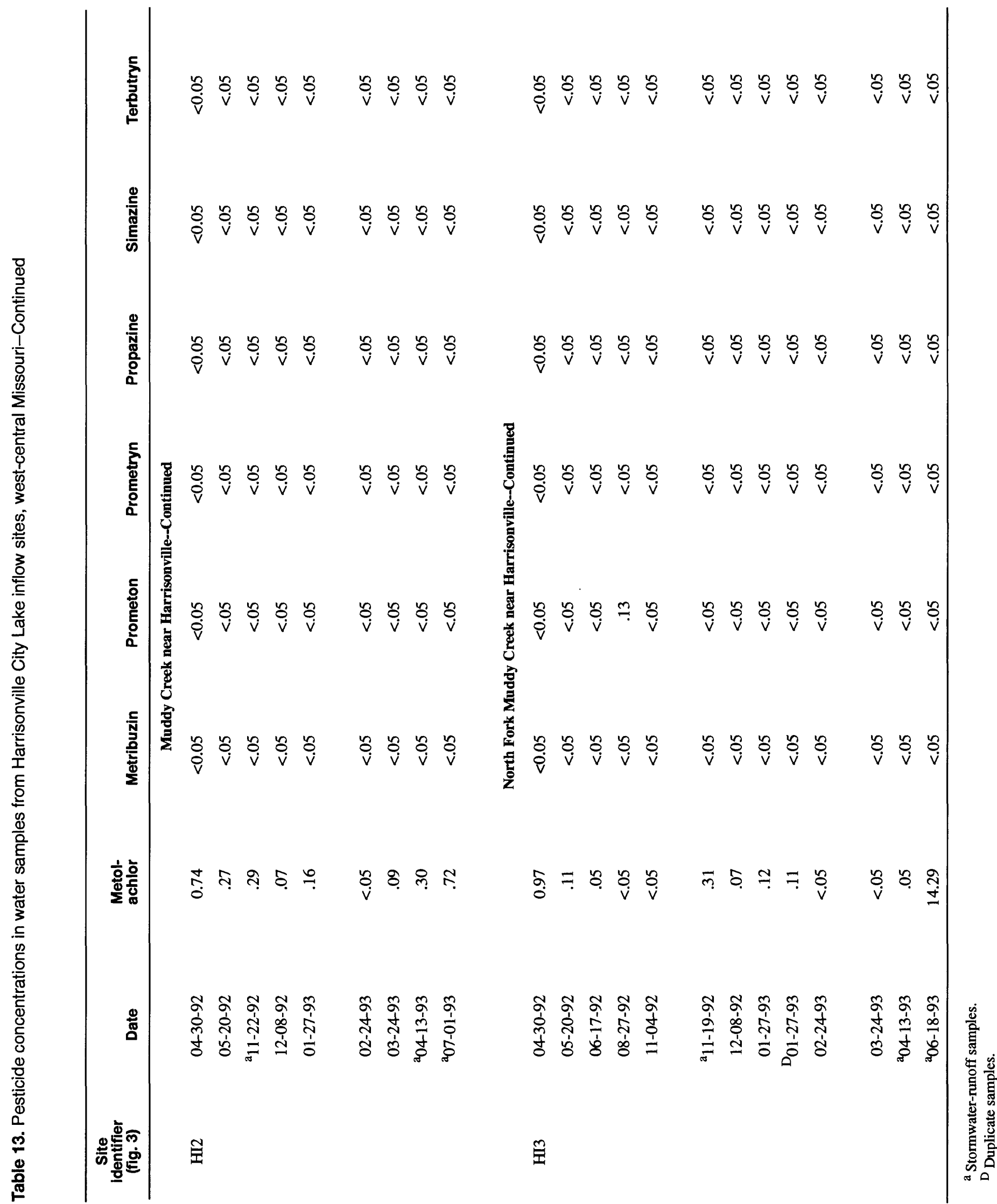
Table 22. Phytoplankton densities and biovolumes in three reservoirs in west-central Missouri [cells $/ \mathrm{mL}$, cells per milliliter; $\mu \mathrm{m}^{3} / \mathrm{mL}$, cubic micrometers per milliliter; -- , no data available]

\begin{tabular}{|c|c|c|c|c|c|c|}
\hline \multirow[b]{2}{*}{$\begin{array}{l}\text { DIVISION } \\
\text { CLASS } \\
\text { Genus species } \\
\end{array}$} & \multicolumn{2}{|c|}{ Site PL1 } & \multicolumn{2}{|c|}{ Site PL2 } & \multicolumn{2}{|c|}{ Site PL3 } \\
\hline & $\begin{array}{c}\text { Density } \\
\text { (cells/mL) }\end{array}$ & $\begin{array}{l}\text { Biovolume } \\
\left(\mu \mathbf{m}^{3} / \mathbf{m L}\right)\end{array}$ & $\begin{array}{c}\text { Density } \\
\text { (cells/mL) }\end{array}$ & $\begin{array}{l}\text { Biovolume } \\
\left(\mu \mathbf{m}^{3} / \mathbf{m L}\right)\end{array}$ & $\begin{array}{c}\text { Density } \\
\text { (cells/mL) }\end{array}$ & $\begin{array}{l}\text { Biovolume } \\
\left(\mu \mathbf{m}^{3} / \mathbf{m L}\right)\end{array}$ \\
\hline \multicolumn{7}{|c|}{$\begin{array}{l}\text { Prairie Lee Lake } \\
\text { May 15, } 1991\end{array}$} \\
\hline \multicolumn{7}{|l|}{ CHRYSOPHYTA } \\
\hline Unknown flagellate & -- & .. & 11,000 & 78,000 & -- & .. \\
\hline \multicolumn{7}{|l|}{ BACILLARIOPHYCEAE } \\
\hline Aulacoseira granulata & -- & -- & 51 & 14,000 & - & .. \\
\hline Aulacoseira italica & -- &.- & 110 & 36,000 & - & -. \\
\hline Cyclotella meneghiniana & - & -- & 1,100 & 93,000 & -- & -- \\
\hline Cyclotella stelligera & -- & - & 150 & 20,000 & - & - \\
\hline Cymbella minuta & -- & -- & 800 & 130,000 & -- & -- \\
\hline Melosira varians & -- & -- & 280 & 12,000 & -- & -- \\
\hline Nitzschia acicularis & -- & -- & 1,600 & 430,000 & -- & - \\
\hline Nitzschia palea & -- & -- & 2,400 & 620,000 & -- & -- \\
\hline Stephanodiscus astraea var minutula &.- & - & 130 & 130,000 & -- & -- \\
\hline Synedra delicatissima & -- & -- & 800 & 100,000 & -- & -- \\
\hline \multicolumn{7}{|l|}{ CHLOROPHYTA } \\
\hline \multicolumn{7}{|l|}{ CHLOROPHYCEAE } \\
\hline Ankistrodesmus falcatus & -- & -- & 1,900 & $1,200,000$ & -- & -- \\
\hline Chlamydomonas sp. & -. & -- & 11,000 & $4,900,000$ & -- & -- \\
\hline Chlorella ellipsoidea & -- & -- & 3,700 & 63,000 & -- & -- \\
\hline Chlorococcum humicola & -. & .. & 3,700 & 550,000 & -. & -- \\
\hline Selenastrum minutum & -- & -. & 15,000 & 270,000 & -- & -- \\
\hline \multicolumn{7}{|l|}{ CYANOPHYTA } \\
\hline \multicolumn{7}{|l|}{ CYANOPHYCEAE } \\
\hline Aphanocapsa delicatissima & -. & - & 270,000 & 270,000 & -- & -- \\
\hline Aphanocapsa elachista & -- & -- & 22,000 & 89,000 & -- &.- \\
\hline Chroococcus sp. & -- & -- & 32,000 & 510,000 & -. & -- \\
\hline Microcystis aeruginosa & -. & - & 160,000 & $2,300,000$ & - & -- \\
\hline \multicolumn{7}{|c|}{ June 3, 1991} \\
\hline \multicolumn{7}{|l|}{ CHRYSOPHYTA } \\
\hline Unknown flagellate & 30,000 & 210,000 & 30,000 & 210,000 & 9,900 & 69,000 \\
\hline BACILLARIOPHYCEAE & & & & & & \\
\hline Asterionella formosa & 1,200 & 390,000 & -- & -- & -- & -- \\
\hline Aulacoseira granulata & - & - & 86 & 24,000 & -- & -- \\
\hline Aulacoseira italica & 740 & 240,000 & -- & -. & 1,100 & 340,000 \\
\hline Aulacoseira italica var tenuissima & 99 & 9,100 & -. & - & - & .. \\
\hline Cocconeis placentula var euglypta & 1,200 & $1,200,000$ & -. & -- & 830 & 810,000 \\
\hline Cyclotella menghiniana & 5,000 & 410,000 & 4,800 & 400,000 & 11,000 & 870,000 \\
\hline Cyclotella stelligera & 790 & 100,000 & 430 & 56,000 & 1,400 & 180,000 \\
\hline Fragilaria vaucheriae & -- & - & -- & -- & 830 & 160,000 \\
\hline Melosira varians & 2,200 & 100,000 & 1,600 & 74,000 & 780 & 35,000 \\
\hline Nitzschia acicularis & -. & -. & 13,000 & $3,600,000$ & 830 & 220,000 \\
\hline Nitzschia palea & -. & - & 1,500 & 390,000 & 2,500 & 650,000 \\
\hline Nitzschia sigma & 2,500 & 300,000 & -- & -- & -. & -- \\
\hline Stephanodiscus astraea var minutula & 1,100 & $1,000,000$ & 430 & 420,000 & 920 & 890,000 \\
\hline CHLOROPHYTA & & & & & & \\
\hline CHLOROPHYCEAE & & & & & & \\
\hline Carteriasp. & 5,000 & 140,000 & -- & -- & -. & -- \\
\hline Chloroccum humicola & -. & -- & -- & -- & 5,000 & 730,000 \\
\hline Selenastrum minutum & 5,000 & 89,000 & .. & -- & 5,000 & 89,000 \\
\hline CYANOPHYTA & & & & & & \\
\hline CYANOPHYCEAE & & & & & & \\
\hline Aphanocapsa delicatissima & 770,000 & 770,000 & 760,000 & 760,000 & 880,000 & 880,000 \\
\hline Aphanocapsa elachista & 59,000 & 240,000 & -. & -. & .- & - \\
\hline Chroococcus sp. & 15,000 & 240,000 & 74,000 & $1,200,000$ & 15,000 & 240,000 \\
\hline Oscillatoria angusta & 40,000 & 240,000 & -. & -- & -- & - \\
\hline CRYPTOPHYTA & & & & & & \\
\hline CRYPTOPHYCEAE & & & & & & \\
\hline Chroomonas sp. & 5,000 & 120,000 & -- &.- & -- & -- \\
\hline Cryptomonas erosa & 5,000 & 470,000 & -- & -. & 5,000 & 470,000 \\
\hline Rhodomonas minuta & - & .. & -- &.- & 5,000 & 54,000 \\
\hline EUGLENOPHYTA & & & & & & \\
\hline EUGLENOPHYCEAE & & & & & & \\
\hline Euglena sp. & 5,000 & $8,400,000$ & -- & -. & .- & -- \\
\hline
\end{tabular}


Table 22. Phytoplankton densities and biovolumes in three reservoirs in west-central Missouri-Continued

\begin{tabular}{|c|c|c|c|c|c|c|}
\hline \multirow[b]{2}{*}{$\begin{array}{l}\text { DIVISION } \\
\text { CLASS } \\
\text { Genus species }\end{array}$} & \multicolumn{2}{|c|}{ Site PLI } & \multicolumn{2}{|c|}{ Site PL2 } & \multicolumn{2}{|c|}{ Site PL3 } \\
\hline & $\begin{array}{l}\text { Density } \\
\text { (cells/mL) }\end{array}$ & $\begin{array}{l}\text { Biovolume } \\
\left(\mu \mathrm{m}^{3} / \mathrm{mL}\right)\end{array}$ & $\begin{array}{l}\text { Density } \\
\text { (cells/mL) }\end{array}$ & $\begin{array}{l}\text { Biovolume } \\
\left(\mu \mathrm{m}^{3} / \mathrm{mL}\right)\end{array}$ & $\begin{array}{l}\text { Density } \\
\text { (cells/mL) }\end{array}$ & $\begin{array}{l}\text { Biovolume } \\
\left(\mu \mathrm{m}^{3} / \mathrm{mL}\right)\end{array}$ \\
\hline \multicolumn{7}{|c|}{$\begin{array}{l}\text { Prairie Lee Lake--Continued } \\
\text { June 12, } 1991\end{array}$} \\
\hline \multicolumn{7}{|l|}{ CHRYSOPHYTA } \\
\hline $\begin{array}{l}\text { Unknown flagellate } \\
\text { BACILLARIOPHYCEAE }\end{array}$ & 22,000 & 160,000 & 7,400 & 52,000 & 7,400 & 52,000 \\
\hline & 2,100 & 670,000 & -. & \multicolumn{3}{|c|}{ BACILLARIOPHYCEAE } \\
\hline Aulacoseira italica var tenuissima & 85 & 7900 & -- & -- & - & - \\
\hline Aulacoseira italica &.- & -- & -. & -- & 100 & 33,000 \\
\hline Cocconeis pediculus & -- & .. & -- & .. & 620 & $5,300,000$ \\
\hline Cocconeis placentula var euglypta & -- & -- & -- & -. & 410 & 410,000 \\
\hline Cyclotella meneghiniana & 3,000 & 250,000 & 2,100 & 170,000 & 5,100 & 420,000 \\
\hline Cyclotella stelligera & 85 & 11,000 & 1,100 & 140,000 & 210 & 27,000 \\
\hline Fragilaria crotonensis & -- & -- & -- & -- & 620 & 240,000 \\
\hline Fragilaria vaucheriae & -- & -- & -- & -- & 210 & 40,000 \\
\hline Melosira varians & 4,000 & 180,000 & 4,200 & 190,000 & 4,400 & 200,000 \\
\hline Navicula cryptocephala & -- & -- & -- & -- & 210 & 270,000 \\
\hline Nitzschia acicularis & 2,100 & 570,000 & -- & - & -- & -- \\
\hline Nitzschia palea & - & -- & -- & -- & 210 & 54,000 \\
\hline Stephanodiscus astraea var minutula & 260 & 250,000 & $-\cdot$ & -. & 100 & 100,000 \\
\hline Surirella linearis & 2,100 & 880,000 & -- & -- & -- & -- \\
\hline Synedra ulna & 1,100 & $1,500,000$ & -. & -- & -- & -- \\
\hline Unknown diatoms & -- & -- & -- & -- & 210 & 3,500 \\
\hline \multicolumn{7}{|l|}{ CHRYSOPHYCEAE } \\
\hline Mallomonas sp. & -- & -- & -. & -- & 7,400 & $10,000,000$ \\
\hline \multicolumn{7}{|l|}{ CHLOROPHYTA } \\
\hline \multicolumn{7}{|l|}{ CHLOROPHYCEAE } \\
\hline Chlorella ellipsoidea & 7,400 & 130,000 & -- & -- & -- & -- \\
\hline Chloroccum humicola & -. & -- & -- & -- & 5,000 & 730,000 \\
\hline Selenastrum minutum & -- & -- & -- & - & 5,000 & 89,000 \\
\hline \multicolumn{7}{|l|}{ CYANOPHYTA } \\
\hline \multicolumn{7}{|l|}{ CYANOPHYCEAE } \\
\hline Aphanocapsa delicatissima & 770,000 & 770,000 & 880,000 & 880,000 & 280,000 & 280,000 \\
\hline Aphanocapsa elachista & -. & -- & 97,000 & 390,000 & 54,000 & 220,000 \\
\hline Aphanothece nidulans & -- & -. & 52,000 & 260,000 & -- & - \\
\hline Chroococcus sp. & 7,400 & 120,000 & 15,000 & 240,000 & 5,000 & 79,000 \\
\hline Dactylococcopsis fascicularis & -- & -- & -- & -- & 2,500 & 120,000 \\
\hline Oscillatoria angusta & 22,000 & 130,000 & 140,000 & 850,000 & -- & - \\
\hline Oscillatoria limnetica & -. & -- & -- & -- & 72,000 & $1,500,000$ \\
\hline \multicolumn{7}{|l|}{ CRYPTOPHYTA } \\
\hline \multicolumn{7}{|l|}{ CHRYPTOPHYCEAE } \\
\hline Chroomonas sp. & 37,000 & 930,000 & 45,000 & $1,100,000$ & 12,000 & 310,000 \\
\hline & & June 2 & & & & \\
\hline CHRYSOPHYTA & & & & & & \\
\hline Unknown flagellate I & 25,000 & 360,000 & $-\cdot$ & - & 13,000 & 180,000 \\
\hline Unknown flagellate II & -- & -- & 39,000 & $555,000,00$ & -- & .. \\
\hline BACILLARIOPHYCEAE & & & & & & \\
\hline Cyclotella sp. & 7,700 & $12,000,000$ & 1,900 & $3,000,000$ & 2,900 & $4,600,000$ \\
\hline Melosira I & 970 & 710,000 & 1,900 & $1,400,000$ & 970 & 710,000 \\
\hline Melosira II & -. & -- & -- & - & 970 & $1,400,000$ \\
\hline Synedra I & 4,800 & $1,000,000$ & 3,900 & 820,000 & 5,800 & $1,200,000$ \\
\hline Synedra II & 970 & $3,100,000$ & 970 & $3,100,000$ & -- & -- \\
\hline CHRYSOPHYCEAE & & & & & & \\
\hline Mallomonas sp. & -- & -- & 970 & 370,000 & -- & - \\
\hline CHLOROPHYTA & & & & & & \\
\hline CHLOROPHYCEAE & & & & & & \\
\hline Ankistrodesmus I & 3,900 & 12,000 & .. & -. & -- & -- \\
\hline Ankistrodesmus II & 2,900 & 50,000 & 3,900 & 67,000 & 970 & 17,000 \\
\hline Carteria I & - & -- & 970 & 600,000 & -- & - \\
\hline Chlamydomonas I & 970 & 400,000 & 1,900 & 790,000 & -- & -- \\
\hline Chlorogonium I & 1,900 & 120,000 & 970 & 61,000 & 2,900 & 180,000 \\
\hline Closteriopsis sp. & 7,700 & $1,500,000$ & 6,800 & $1,300,000$ & 6,800 & $1,300,000$ \\
\hline Coelastrum II & 13,000 & $8,800,000$ & 9,700 & $89,000,000$ & 8,700 & $80,000,000$ \\
\hline Crucigenia II & 1,900 & 390,000 & -- & -- & -- & -- \\
\hline Dictyosphaerium sp. & - & -- & 970 & 170,000 & 970 & 170,000 \\
\hline
\end{tabular}


Table 22. Phytoplankton densities and biovolumes in three resenoirs in west-central Missouri--Continued

\begin{tabular}{|c|c|c|c|c|c|c|}
\hline \multirow[b]{2}{*}{$\begin{array}{l}\text { DIVISION } \\
\text { CLASS } \\
\text { Genus species }\end{array}$} & \multicolumn{2}{|c|}{ Site PLI } & \multicolumn{2}{|c|}{ Site PL2 } & \multicolumn{2}{|c|}{ Site PL3 } \\
\hline & $\begin{array}{l}\text { Density } \\
\text { (cells/mL) }\end{array}$ & $\begin{array}{l}\text { Biovolume } \\
\left(\mu \mathbf{m}^{3} / \mathbf{m L}\right)\end{array}$ & $\begin{array}{l}\text { Denslty } \\
\text { (cells/mL) }\end{array}$ & $\begin{array}{l}\text { Biovolume } \\
\left(\mu \mathrm{m}^{3} / \mathrm{mL}\right)\end{array}$ & $\begin{array}{l}\text { Density } \\
\text { (cells/mL) }\end{array}$ & $\begin{array}{l}\text { Biovolume } \\
\left(\mu \mathrm{m}^{3} / \mathrm{mL}\right)\end{array}$ \\
\hline \multicolumn{7}{|c|}{$\begin{array}{l}\text { Prairie Lee Lake--Continued } \\
\text { June 26, 1991--Continued }\end{array}$} \\
\hline \multirow{2}{*}{\multicolumn{7}{|c|}{$\begin{array}{l}\text { CHLOROPHYTA--Continued } \\
\text { CHLOROPHYCEAE--Continued }\end{array}$}} \\
\hline & & & & & & \\
\hline Golenkinia sp. & 970 & 32,000 & 970 & 32,000 & 970 & 32,000 \\
\hline Oocystis sp. & 970 & 510,000 & 1,900 & $1,000,000$ & 970 & 510,000 \\
\hline Scenedesmus I & -- & - & -- & -- & 970 & 430,000 \\
\hline Scenedesmus II & 970 & 29,000 & 970 & 29,000 & 1,900 & 58,000 \\
\hline Scenedesmus III & -- & - & 970 & 97,000 & -- & -- \\
\hline Selenastrum sp. & 9,700 & 160,000 & 22,000 & 370,000 & 16,000 & 270,000 \\
\hline \multicolumn{7}{|l|}{ CYANOPHYTA } \\
\hline \multicolumn{7}{|l|}{ CYANOPHYCEAE } \\
\hline Anacystis sp. & -. & .. & 3,900 & $2,000,000$ & 1,900 & $1,000,000$ \\
\hline Oscillatoria III & 390,000 & $63,000,000$ & 460,000 & $75,000,000$ & 320,000 & $52,000,000$ \\
\hline Oscillatoria IV & 2,900 & $6,900,000$ & 11,000 & $25,000,000$ & 970 & $2,300,000$ \\
\hline \multicolumn{7}{|l|}{ CRYPTOPHYTA } \\
\hline \multicolumn{7}{|l|}{ CRYPTOPHYCEAE } \\
\hline Chroomonas sp. & 970 & 17,000 & 3,900 & 69,000 & 1,900 & 34,000 \\
\hline Cryptomonas I & -. & -- & 3,900 & 330,000 & 9,700 & 820,000 \\
\hline Cryptomonas II & 7,700 & 150,000 & 13,000 & 250,000 & 1,900 & 39,000 \\
\hline \multicolumn{7}{|l|}{ EUGLENOPHYTA } \\
\hline \multicolumn{7}{|l|}{ EUGLENOPHYCEAE } \\
\hline Euglena I & -. & - & 970 & $7,200,000$ & -- & .. \\
\hline Lepocinclis sp. & -- & -- & 970 & 100,000 & -- & -- \\
\hline Trachelomonas IV & -- & - & 2,900 & 780,000 & 1,900 & 520,000 \\
\hline Trachelomonas V & -- & -- & 1,900 & $10,000,000$ & -- & -- \\
\hline Trachelomonas VII & 1,900 & $1,000,000$ & .. & .- & 970 & 510,000 \\
\hline \multicolumn{7}{|l|}{ PYRROPHYTA } \\
\hline \multicolumn{7}{|l|}{ DINOPHYCEAE } \\
\hline Gymnodinium sp. & -- & -. & 970 & $1,700,000$ & -- & -. \\
\hline Peridinium sp. & -- & -- & 3,900 & $10,000,000$ & -- & -. \\
\hline & & July 1 & & & & \\
\hline CHRYSOPHYTA & & & & & & \\
\hline Unknown flagellate I & -- & -- & 22,000 & 310,000 & 26,000 & 370,000 \\
\hline Unknown flagellate II & 17,000 & $25,000,000$ & .. & -. & 970 & $1,400,000$ \\
\hline BACILLARIOPHYCEAI & & & & & & \\
\hline Cyclotella sp. & 970 & $1,500,000$ & - & -- & 970 & $1,500,000$ \\
\hline Melosira I & - & - & -- & -- & 4,800 & $3,600,000$ \\
\hline Rhizosolenium sp. & 970 & 720,000 & -- & -- & 970 & 720,000 \\
\hline Synedra I & 76,000 & $16,000,000$ & 110,000 & $23,000,000$ & 52,000 & $11,000,000$ \\
\hline CHLOROPHYTA & & & & & & \\
\hline CHLOROPHYCEAE & & & & & & \\
\hline Ankistrodesmus I & 970 & 3,000 & .. & -- & 970 & 2,900 \\
\hline Ankistrodesmus II & -- & -- & 1,900 & 33,000 & - & - \\
\hline Botryococcus sp. & -- & -- & .. & .. & 970 & $1,700,000$ \\
\hline Closteriopsis sp. & 1,900 & 370,000 & -. & -- & -. & - \\
\hline Coelastrum II & - & -- & 3,900 & 270,000 & 1,900 & $1,300,000$ \\
\hline Crucigenia II & 970 & 190,000 & .. & - & 5,800 & $1,200,000$ \\
\hline Oocystis sp. & 970 & 510,000 & 2,900 & $1,500,000$ & - & - \\
\hline Scenedesmus II & -- & -- & -- & - & 970 & 29,000 \\
\hline Selenastrum sp. & 1,900 & 32,000 & 4,800 & 81,000 & -- & -. \\
\hline Tetraedron I & .- & -- & -- & - & 2,900 & 760,000 \\
\hline CYANOPHYTA & & & & & & \\
\hline CYANOPHYCEAE & & & & & & \\
\hline Anacystis sp. & 1,900 & $1,000,000$ & 4,800 & $2,500,000$ & -- & -. \\
\hline Dactylococcopsis sp. & 190,000 & $27,000,000$ & 710,000 & $100,000,000$ & 430,000 & $60,000,000$ \\
\hline Lyngbya sp. & 6,800 & 200,000 & 3,900 & 120,000 & 5,800 & 170,000 \\
\hline Oscillatoria II & -- & -- & 5,800 & 950,000 & -- & -- \\
\hline Oscillatoria III & 2,900 & 470,000 & - & .. & 3,900 & 630,000 \\
\hline CRYPTOPHYTA & & & & & & \\
\hline CRYPTOPHYCEAE & & & & & & \\
\hline Cryptomonas I & 3,900 & 330,000 & 3,900 & 330,000 & .. & -- \\
\hline Cryptomonas II & 5,900 & 120,000 & 5,800 & 120,000 & 7,700 & 150,000 \\
\hline
\end{tabular}


Table 22. Phytoplankton densities and biovolumes in three reservoirs in west-central Missouri--Continued

\begin{tabular}{|c|c|c|c|c|c|c|}
\hline \multirow[b]{2}{*}{$\begin{array}{l}\text { DIVISION } \\
\text { CLASS } \\
\text { Genus species }\end{array}$} & \multicolumn{2}{|c|}{ Site PL1 } & \multicolumn{2}{|c|}{ Site PL2 } & \multicolumn{2}{|c|}{ Site PL3 } \\
\hline & $\begin{array}{l}\text { Density } \\
\text { (cells/mL) }\end{array}$ & $\begin{array}{l}\text { Biovolume } \\
\left(\mu \mathbf{m}^{3} / \mathbf{m L}\right)\end{array}$ & $\begin{array}{c}\text { Density } \\
\text { (cells/mL) }\end{array}$ & $\begin{array}{l}\text { Biovolume } \\
\left(\mu \mathbf{m}^{3} / \mathbf{m L}\right)\end{array}$ & $\begin{array}{c}\text { Density } \\
\text { (cells/mL) }\end{array}$ & $\begin{array}{l}\text { Biovolume } \\
\left(\mu \mathbf{m}^{3} / \mathbf{m L}\right)\end{array}$ \\
\hline \multicolumn{7}{|c|}{$\begin{array}{l}\text { Prairie Lee Lake--Continued } \\
\text { July 10, 1991--Continued }\end{array}$} \\
\hline \multicolumn{7}{|l|}{ EUGLENOPHYTA } \\
\hline \multicolumn{7}{|l|}{ EUGLENOPHYCEAE } \\
\hline Euglena I & 970 & $7,200,000$ & $-\cdot$ & -- & -- & - \\
\hline Trachelomonas I & -- & - & -- & -- & 1,900 & $4,100,000$ \\
\hline Trachelomonas IV & 970 & 260,000 & 1,900 & 520,000 & 970 & 260,000 \\
\hline Trachelomonas VI & -- & -- & -- & -- & 970 & $1,100,000$ \\
\hline \multicolumn{7}{|l|}{ PYRROPHYTA } \\
\hline \multicolumn{7}{|l|}{ DINOPHYCEAE } \\
\hline Peridinium sp. & -- & -- & 1,900 & $5,100,000$ & 3,900 & $10,000,000$ \\
\hline \multicolumn{7}{|c|}{ July 24, 1991} \\
\hline \multicolumn{7}{|l|}{ CHRYSOPHYTA } \\
\hline Unknown fiagellate I & 12,000 & 160,000 & 11,000 & 150,000 & 6,800 & 96,000 \\
\hline \multicolumn{7}{|l|}{ BACILLARIOPHYCEAE } \\
\hline Cyclotella sp. & 1,900 & $3,000,000$ & -- & -- & -- & -- \\
\hline Nitzschia I & 970 & 690,000 & -- & -- & -- & - \\
\hline Nitzschia II & 970 & 50,000 & -- & -- & 970 & 50,000 \\
\hline Rhizosolenium sp. & 970 & 720,000 & 970 & 720,000 & & \\
\hline Synedra I & 3,900 & 820,000 & 6,800 & $1,400,000$ & 2,900 & 620,000 \\
\hline \multicolumn{7}{|l|}{ CHRYSOPHYCEAE } \\
\hline Chrysoamoeba sp. & 970 & $3,000,000$ & 970 & $3,000,000$ & -- &.- \\
\hline \multicolumn{7}{|l|}{ CHLOROPHYTA } \\
\hline \multicolumn{7}{|l|}{ CHLOROPHYCEAE } \\
\hline Ankistrodesmus II & - & -- & 970 & 17,000 & 1,900 & 33,000 \\
\hline Crucigenia I & 1,900 & 120,000 & -- & -- & -- & -- \\
\hline Oocystis sp. & 970 & 510,000 & -. & -- & -. & -- \\
\hline Quadrigula sp. & -- & -- & -- & -- & 970 & 48,000 \\
\hline Selenastrum sp. & 970 & 16,000 & 2,900 & 48,000 & -- & -- \\
\hline Tetraedron I & -- & -. & 6,800 & $1,800,000$ & -- & -- \\
\hline Tetraedron II & 3,900 & $2,200,000$ & .. & - & 970 & 560,000 \\
\hline CYANOPHYTA & & & & & & \\
\hline CYANOPHYCEAE & & & & & & \\
\hline Anacystis sp. & 1,900 & $1,000,000$ & 13,000 & $6,600,000$ & 4,800 & $2,500,000$ \\
\hline Dactylococcopsis sp. & 17,000 & $2,500,000$ & 30,000 & $4,200,000$ & 2,900 & 410,000 \\
\hline Lyngbya sp. & 9,700 & 290,000 & 21,000 & 640,000 & 8,700 & 260,000 \\
\hline Oscillatoria I & 5,800 & 950,000 & 5,800 & 950,000 & 2,900 & 470,000 \\
\hline Raphidiopsis sp. & 970 & 15,000 & 2,900 & 46,000 & 970 & 15,000 \\
\hline Synechococcus sp. & -- & -. & -- & -- & 2,900 & 130,000 \\
\hline CRYPTOPHYTA & & & & & & \\
\hline CRYPTOPHYCEAE & & & & & & \\
\hline Chroomonas sp. & 970 & 17,000 & 970 & 17,000 & -- & -- \\
\hline Cryptomonas I & -- & -- & 1,900 & 160,000 & 970 & 82,000 \\
\hline Cryptomonas II & 9,700 & 190,000 & 4,800 & 97,000 & 7,700 & 150,000 \\
\hline EUGLENOPHYTA & & & & & & \\
\hline EUGLENOPHYCEAE & & & & & & \\
\hline Euglena I & -- & -- & 970 & $7,200,000$ & -- & -- \\
\hline Trachelomonas IV & -- & -- & -- & -. & 970 & 260,000 \\
\hline Trachelomonas VI & 2,900 & $3,200,000$ & 3,900 & $4,300,000$ & 970 & $1,100,000$ \\
\hline PYRROPHYTA & & & & & & \\
\hline DINOPHYCEAE & & & & & & \\
\hline Gymnodinium sp. & 1,900 & 350,000 & -. & - & 2,900 & $5,200,000$ \\
\hline Peridinium sp. & 970 & $2,600,000$ & 970 & $2,600,000$ & 970 & $2,600,000$ \\
\hline & & August & & & & \\
\hline CHRYSOPHYTA & & & & & & \\
\hline Unknown flagellate I & 5,800 & 82,000 & 14,000 & 190,000 & 14,000 & 190,000 \\
\hline Unknown flagellate II & 3,900 & $5,500,000$ & -- & -- & -- & -. \\
\hline BACILLARIOPHYCEAE & & & & & & \\
\hline Cyclotella sp. & 7,700 & $12,000,000$ & 6,800 & $11,000,000$ & 3,900 & $6,100,000$ \\
\hline Nitzschia I & -- & - & -- & - & 970 & 690,000 \\
\hline Synedra I & 8,700 & $1,800,000$ & 4,800 & $1,000,000$ & 15,000 & 3,300000 \\
\hline
\end{tabular}


Table 22. Phytoplankton densities and biovolumes in three reservoirs in west-central Missouri-Continued

\begin{tabular}{|c|c|c|c|c|c|c|}
\hline \multirow[b]{2}{*}{$\begin{array}{l}\text { DIVISION } \\
\text { CLASS } \\
\text { Genus species }\end{array}$} & \multicolumn{2}{|c|}{ Site PLI } & \multicolumn{2}{|c|}{ Site PL2 } & \multicolumn{2}{|c|}{ Site PL3 } \\
\hline & $\begin{array}{c}\text { Density } \\
\text { (cells/mL) }\end{array}$ & $\begin{array}{l}\text { Biovolume } \\
\left(\mu \mathrm{m}^{3} / \mathrm{mL}\right)\end{array}$ & $\begin{array}{c}\text { Density } \\
\text { (cells/mL) }\end{array}$ & $\begin{array}{l}\text { Biovolume } \\
\left(\mu \mathbf{m}^{3} / \mathbf{m L}\right)\end{array}$ & $\begin{array}{c}\text { Density } \\
\text { (cells/mL) }\end{array}$ & $\begin{array}{l}\text { Biovolume } \\
\left(\mu \mathbf{m}^{3} / \mathbf{m L}\right)\end{array}$ \\
\hline \multicolumn{7}{|c|}{$\begin{array}{l}\text { Prairie Lee Lake--Continued } \\
\text { August 7, 1991--Continued }\end{array}$} \\
\hline CHRYSOPHYCEAE & & & & & & \\
\hline Kephyrion sp. & -- & -- & -- & -- & 970 & 63,000 \\
\hline Chrysoamoeba sp. & 970 & $3,000,000$ & -- & -- & -- & -- \\
\hline Mallomonas I & -- & -. & 1,900 & 740,000 & 970 & 370,000 \\
\hline Mallomonas II & 6,800 & $15,000,000$ & 4,800 & $10,000,000$ & 3,900 & $8,300,000$ \\
\hline \multicolumn{7}{|l|}{ CHLOROPHYTA } \\
\hline \multicolumn{7}{|l|}{ CHLOROPHYCEAE } \\
\hline Ankistrodesmus I & -- & -- & 970 & 3,000 & -- & -- \\
\hline Ankistrodesmus II & 970 & 17,000 & 970 & 17,000 & -- & -. \\
\hline Chlamydomonas I & 970 & 400,000 & -- & -- & 1,900 & 790,000 \\
\hline Chlorogonium I & -- & - & 1,900 & 120,000 & -- & -- \\
\hline Closteriopsis sp. & 970 & 180,000 & - & -- & 970 & 180,000 \\
\hline Dictyosphaerium sp. & -- & -- & 970 & 170,000 & -- & -- \\
\hline Quadrigula sp. & -- & -. & 970 & 48,000 & -- & - \\
\hline Selenastrum sp. & 1,900 & 32,000 & 1,900 & 32,000 & 4,800 & 81,000 \\
\hline Sphaerellopsis sp. & 970 & 63,000 & - & - & - & - \\
\hline Tetraedron II & .. & -. & 970 & 560,000 & -- & .- \\
\hline Tetraedron III & -. & -- & 970 & 250,000 & -- & -- \\
\hline \multicolumn{7}{|l|}{ CYANOPHYTA } \\
\hline \multicolumn{7}{|l|}{ CYANOPHYCEAE } \\
\hline Anacystis sp. & 11,000 & $5,600,000$ & 2,900 & $1,500,000$ & 15,000 & $8,100,000$ \\
\hline Dactylococcopsis sp. & - & - & 970 & 140,000 & -- & -- \\
\hline Lyngbya sp. & 20,000 & 610,000 & 8,700 & 260,000 & 9,700 & 290,000 \\
\hline Oscillatoria I & 80,000 & $13,000,000$ & 110,000 & $18,000,000$ & 68,000 & $11,000,000$ \\
\hline Raphidiopsis sp. & 140,000 & $2,200,000$ & 230,000 & $3,600,000$ & 140,000 & $2,100,000$ \\
\hline \multicolumn{7}{|l|}{ CRYPTOPHYTA } \\
\hline Chroomonas sp. & 970 & 17,000 & 1,900 & 34,000 & 3,900 & 69,000 \\
\hline Cryptomonas I & 1,900 & 160,000 & -- & -- & 3,900 & 330,000 \\
\hline Cryptomonas II & - & -. & 6,800 & 140,000 & 7,700 & 150,000 \\
\hline \multicolumn{7}{|l|}{ EUGLENOPHYTA } \\
\hline \multicolumn{7}{|l|}{ EUGLENOPHYCEAE } \\
\hline Euglena I & 2,900 & $22,000,000$ & -. & .. & -- & -. \\
\hline Trachelomonas IV & 970 & 260,000 & -. & -- & -- & -. \\
\hline Trachelomonas $\mathrm{V}$ & -- & .. & -- & -- & 970 & $5,100,000$ \\
\hline \multicolumn{7}{|l|}{ PYRROPHYTA } \\
\hline DINOPHYCEAE & & & & & & \\
\hline Ceratium sp. & 1,900 & $7,300,000$ & -- & - & -- & -. \\
\hline Peridinium sp. & -- & - & - & - & 1,900 & $5,100,000$ \\
\hline & & August & & & & \\
\hline CHRYSOPHYTA & & & & & & \\
\hline Unknown flagellate I & 9,700 & 140,000 & 8,700 & 120,000 & 15,000 & 210,000 \\
\hline BACILLARIOPHYCEAE & & & & & & \\
\hline Cyclotella $s p$ & 5,800 & $9,100,000$ & -- & -- & 3,900 & $6,100,000$ \\
\hline Synedra I & 970 & 210,000 & 3,900 & 820,000 & 4,800 & $1,000,000$ \\
\hline CHRYSOPHYCEAE & & & & & & \\
\hline Chrysoamoeba sp. & -- & -- & 970 & $3,000,000$ & -- & -- \\
\hline Kephyrion sp. & 2,900 & 190,000 & -. & -. & 970 & 63,000 \\
\hline Mallomonas II & - & -. & -- & -- & 970 & $2,100,000$ \\
\hline CHLOROPHYTA & & & & & & \\
\hline CHLOROPHYCEAE & & & & & & \\
\hline Ankistrodesmus II & 970 & 17,000 & 3,900 & 12,000 & -- & -- \\
\hline Carteria I & -- & -- & -- & -- & 970 & 600,000 \\
\hline Chlamydomonas I & 1,900 & 790,000 & -. & -. & 970 & 400,000 \\
\hline Closteriopsis sp. & 970 & 180,000 & 970 & 180,000 & - & -- \\
\hline Cosmarium sp. & -- & .. & 970 & 93,000 & -. & -- \\
\hline Scenedesmus II & 1,900 & 860,000 & 970 & 430,000 & -- & -. \\
\hline Selenastrum sp. & 4,800 & 81,000 & 7,700 & 130,000 & 1,900 & 32,000 \\
\hline Sphaerellopsis sp. & -- & -. & .. & -- & 1,900 & 130,000 \\
\hline Tetraedron I & 970 & 250,000 & 1,900 & 510,000 & 970 & 250,000 \\
\hline CYANOPHYTA & & & & & & \\
\hline CYANOPHYCEAE & & & & & & \\
\hline Anacystis sp. & 3,900 & 630,000 & 24,000 & $13,000,000$ & 7,700 & $4,100,000$ \\
\hline
\end{tabular}


Table 22. Phytoplankton densities and biovolumes in three reservoirs in west-central Missouri--Continued

\begin{tabular}{|c|c|c|c|c|c|c|}
\hline \multirow[b]{2}{*}{$\begin{array}{l}\text { DIVISION } \\
\text { CLASS } \\
\text { Genus species }\end{array}$} & \multicolumn{2}{|c|}{ Site PLI } & \multicolumn{2}{|c|}{ Site PL2 } & \multicolumn{2}{|c|}{ Site PL3 } \\
\hline & $\begin{array}{l}\text { Density } \\
\text { (cells/mL) }\end{array}$ & $\begin{array}{l}\text { Biovolume } \\
\left(\mu \mathbf{m}^{3} / \mathbf{m L}\right)\end{array}$ & $\begin{array}{l}\text { Density } \\
\text { (cells/mL) }\end{array}$ & $\begin{array}{l}\text { Biovolume } \\
\left(\mu \mathrm{m}^{3} / \mathrm{mL}\right)\end{array}$ & $\begin{array}{l}\text { Density } \\
\text { (cells/mL) }\end{array}$ & $\begin{array}{l}\text { Biovolume } \\
\left(\mu \mathrm{m}^{3} / \mathrm{mL}\right)\end{array}$ \\
\hline \multicolumn{7}{|c|}{$\begin{array}{l}\text { Prairie Lee Lake--Continued } \\
\text { August 21, 1991--Continued }\end{array}$} \\
\hline \multicolumn{7}{|c|}{$\begin{array}{l}\text { CYANOPHYTA--Continued } \\
\text { CYANOPHYCEAE--Continued }\end{array}$} \\
\hline Gloeocapsa sp. & -- & -- & -- & -- & 970 & 63,000 \\
\hline Lyngbya sp. & 13,000 & 380,000 & 32,000 & 950,000 & 27,000 & 810,000 \\
\hline Oscillatoria I & 61,000 & $10,000,000$ & 75,000 & $12,000,000$ & 93,000 & $15,000,000$ \\
\hline Raphidiopsis sp. & 8,700 & 140,000 & 22,000 & 350,000 & 34,000 & 530,000 \\
\hline \multicolumn{7}{|l|}{ CRYPTOPHYTA } \\
\hline \multicolumn{7}{|l|}{ CRYPTOPHYCEAE } \\
\hline Chroomonas sp. & 2,900 & 52,000 & -- & -- & 6,800 & 120,000 \\
\hline Cryptomonas I & 18,000 & $1,600,000$ & 4,800 & 410,000 & 2,900 & 240,000 \\
\hline Cryptomonas II & 6,800 & 140,000 & 3,900 & 77,000 & 970 & 19,000 \\
\hline \multicolumn{7}{|l|}{ EUGLENOPHYTA } \\
\hline \multicolumn{7}{|l|}{ EUGLENOPHYCEAE } \\
\hline Euglena I & 4,800 & $36,000,000$ & -- & -- & -- & -- \\
\hline Trachelomonas I & -- & -- & 970 & $2,000,000$ & -- & -. \\
\hline Trachelomonas IV & -- & .- & 1,900 & 520,000 & -- & -- \\
\hline Trachelomonas V & 970 & $5,100,000$ & 970 & $5,100,000$ & 2,900 & $15,000,000$ \\
\hline \multicolumn{7}{|l|}{ PYRROPHYTA } \\
\hline \multicolumn{7}{|l|}{ DINOPHYCEAE } \\
\hline Gymnodinium sp. & -- & -- & -- & -- & 2,900 & $5,200,000$ \\
\hline Peridinium sp. & -- & -- & 1,900 & $5,100,000$ & -- & -- \\
\hline \multicolumn{7}{|c|}{ September 12, 1991} \\
\hline \multicolumn{7}{|l|}{ CHRYSOPHYTA } \\
\hline Unknown flagellate I & 12,000 & $1,60,000$ & 17,000 & 250,000 & 24,000 & 340,000 \\
\hline Unknown flagellate II & 970 & $1,400,000$ & -. & -- & 970 & $1,400,000$ \\
\hline BACILLARIOPHYCEAE & & & & & & \\
\hline Cyclotella sp. & 970 & $1,500,000$ & 970 & $1,500,000$ & 3,900 & $6,100,000$ \\
\hline Eunotia sp. & 970 & 9,700 & - & - & 970 & 9,700 \\
\hline Nitzschia I & 1,900 & $1,400,000$ & -- & - & 1,900 & $1,400,000$ \\
\hline Rhizosolenium sp. & 970 & 720,000 & -- & -- & -- & -- \\
\hline Synedra I & 7,700 & $1,600,000$ & .. & _- & 7,700 & $1,600,000$ \\
\hline CHRYSOPHYCEAE & & & & & & \\
\hline Kephyrion sp. & 2,900 & 190,000 & 970 & 63,000 & 970 & 63,000 \\
\hline Mallomonas I & 1,900 & 740,000 & -- & -- & 9,700 & $3,700,000$ \\
\hline Mallomonas II & 970 & $2,100,000$ & -- & .- & -- & -- \\
\hline Ochromonas sp. & 970 & 110,000 & -- & - & -- & -- \\
\hline CHLOROPHYTA & & & & & & \\
\hline CHLOROPHYCEAE & & & & & & \\
\hline Ankistrodesmus II & 28,000 & 490,000 & 15,000 & 250,000 & 14,000 & 230,000 \\
\hline Carteria I & 970 & 600,000 & -- & - & 970 & 600,000 \\
\hline Chlamydomonas I & 2,900 & $1,200,000$ & 1,900 & 790,000 & 2,900 & $1,200,000$ \\
\hline Chlorogonium I & 1,900 & 120,000 & 1,900 & 120,000 & 970 & 61,000 \\
\hline Closteriopsis sp. & -- & -- & 1,900 & 370,000 & 1,900 & 370,000 \\
\hline Coelastrum II & 970 & 670,000 & -- & -. & .. & -- \\
\hline Crucigenia II & 970 & 62,000 & -- & -- & -- & -- \\
\hline Scenedesmus I & 1,900 & 860,000 & 970 & 430,000 & 2,900 & $1,300,000$ \\
\hline Selenastrum sp. & 1,900 & 32,000 & 970 & 16,000 & 970 & 16,000 \\
\hline Sphaerellopsis sp. & 970 & 63,000 & .. & -- & -- & .. \\
\hline Stichococcus sp. & -- & -. & -. & -- & 970 & 12,000 \\
\hline Tetraedron I & 1,900 & 510,000 & 970 & 250,000 & .- & -. \\
\hline CYANOPHYTA & & & & & & \\
\hline CYANOPHYCEAE & & & & & & \\
\hline Anacystis sp. & 43,000 & $22,000,000$ & 28,000 & $15,000,000$ & 27,000 & $14,000,000$ \\
\hline Gloeocapsa sp. & 1,900 & 65,000 & - & - & - & - \\
\hline Lyngbya sp. & 88,000 & $2,600,000$ & 48,000 & $1,400,000$ & 38,000 & $1,100,000$ \\
\hline Oscillatoria I & 81,000 & $13,000,000$ & 52,000 & $8,500,000$ & 82,000 & $13,000,000$ \\
\hline Raphidiopsis sp. & 21,000 & 330,000 & 6,800 & 110,000 & 17,000 & 270,000 \\
\hline CRYPTOPHYTA & & & & & & \\
\hline CRYPTOPHYCEAE & & & & & & \\
\hline Chroomonas sp. & 970 & 17,000 & -- & .- & 24,000 & 430,000 \\
\hline Cryptomonas I & 7,700 & 650,000 & 4,800 & 410,000 & 20,000 & $1,700,000$ \\
\hline Cryptomonas II & 20,000 & 410,000 & 14,000 & 270,000 & 4,800 & 97,000 \\
\hline
\end{tabular}


Table 22. Phytoplankton densities and biovolumes in three reservoirs in west-central Missouri--Continued

\begin{tabular}{|c|c|c|c|c|c|c|}
\hline \multirow[b]{2}{*}{$\begin{array}{l}\text { DIVISION } \\
\text { CLASS } \\
\text { Genus species }\end{array}$} & \multicolumn{2}{|c|}{ Site PL1 } & \multicolumn{2}{|c|}{ Site PL2 } & \multicolumn{2}{|c|}{ Site PL3 } \\
\hline & $\begin{array}{c}\text { Density } \\
\text { (cells/mL) }\end{array}$ & $\begin{array}{l}\text { Biovolume } \\
\left(\mu \mathbf{m}^{3} / \mathbf{m L}\right)\end{array}$ & $\begin{array}{c}\text { Density } \\
\text { (cells/mL) }\end{array}$ & $\begin{array}{l}\text { Biovolume } \\
\left(\mu \mathbf{m}^{3} / \mathbf{m L}\right)\end{array}$ & $\begin{array}{c}\text { Density } \\
\text { (cells/mL) }\end{array}$ & $\begin{array}{l}\text { Biovolume } \\
\left(\mu \mathrm{m}^{3} / \mathrm{mL}\right)\end{array}$ \\
\hline \multicolumn{7}{|c|}{$\begin{array}{l}\text { Prairie Lee Lake--Continued } \\
\text { September 12, 1991--Continued }\end{array}$} \\
\hline \multicolumn{7}{|l|}{ EUGLENOPHYTA } \\
\hline \multicolumn{7}{|l|}{ EUGLENOPHYCEAE } \\
\hline Trachelomonas I & 1,900 & $4,100,000$ & -. & -- & 2,900 & $6,100,000$ \\
\hline Trachelomonas II & -- & -- & .. & .. & 970 & $4,100,000$ \\
\hline Trachelomonas III & 1,900 & $4,200,000$ & -- & -. & 970 & $2,100,000$ \\
\hline Trachelomonas IV & 1,900 & 520,000 & 970 & 260,000 & .. & - \\
\hline Trachelomonas V & -- & -- &.- & -- & 1,900 & $10,000,000$ \\
\hline \multicolumn{7}{|l|}{ PYRROPHYTA } \\
\hline \multicolumn{7}{|l|}{ DINOPHYCEAE } \\
\hline Ceratium sp. & -- & -- & -- & -. & 970 & $3,700,000$ \\
\hline Gymnodinium sp. & 970 & $1,700,000$ & -- & .- & -- & -- \\
\hline Peridinium sp. & 970 & $2,600,000$ & 970 & $2,600,000$ & -- & -- \\
\hline \multicolumn{7}{|c|}{ September 26, 1991} \\
\hline \multicolumn{7}{|l|}{ CHRYSOPHYTA } \\
\hline Unknown flagellate I & 1,900 & 27,000 & 7,700 & 110,000 & 7,700 & 110,000 \\
\hline \multicolumn{7}{|l|}{ BACILLARIOPHYCEAE } \\
\hline Cyclotella sp. & 970 & $1,500,000$ & 1,900 & $3,000,000$ & 1,900 & $3,000,000$ \\
\hline Synedra I & 2,900 & 620,000 & 970 & 210,000 & 3,900 & 820,000 \\
\hline \multicolumn{7}{|l|}{ CHRYSOPHYCEAE } \\
\hline Kephyrion sp. & 1,900 & 130,000 & .. & -- &.- & - \\
\hline Ochromonas sp. & 970 & 110,000 & -- & -- & -- & -- \\
\hline \multicolumn{7}{|l|}{ CHLOROPHYTA } \\
\hline \multicolumn{7}{|l|}{ CHLOROPHYCEAE } \\
\hline Ankistrodesmus II & 84,000 & $1,500,000$ & 120,000 & $2,000,000$ & 89,000 & $1,500,000$ \\
\hline Carteria I & -- & -. & 1,900 & $1,200,000$ & -- & - \\
\hline Chlamydomonas I & -- & -- & 970 & 400,000 & -- & -- \\
\hline Chlorogonium I & -- & -- & 970 & 61,000 & -. & -- \\
\hline Closteriopsis sp. & -- & -- & -- & -- & 970 & 180,000 \\
\hline Coelastrum I & -- & -. & -- & -- & 970 & 670,000 \\
\hline Crucigenia I & 970 & 62,000 & -- & .- & $\cdots$ & .. \\
\hline Scenedesmus I & -- & -- & 1,900 & 860,000 & -- & -- \\
\hline Scenedesmus II & -- & -- & - & -- & 1,900 & 58,000 \\
\hline Scenedesmus III & -- & -- & -- & -- & 970 & 97,000 \\
\hline Selenastrum sp. & 2,900 & 48,000 & 970 & 16,000 & -- & -. \\
\hline Tetraedron I & 970 & 250,000 & -- & -- & -- & -- \\
\hline \multicolumn{7}{|l|}{ CYANOPHYTA } \\
\hline \multicolumn{7}{|l|}{ CYANOPHYCEAE } \\
\hline Anacystis sp. & 8,700 & $4,600,000$ & 6,800 & $3,500,000$ & 14,000 & $7,100,000$ \\
\hline Gloeocapsa sp. & 970 & 63,000 & -- & -- & -- & -. \\
\hline Lyngbya sp. & 12,000 & 350,000 & 7,700 & 230,000 & 12,000 & 350,000 \\
\hline Oscillatoria I & 23,000 & $3,800,000$ & 20,000 & $3,300,000$ & 32,000 & $5,200,000$ \\
\hline Oscillatoria II & 970 & 160,000 & 970 & 160,000 & -. & - \\
\hline Raphidiopsis sp. & 4,800 & 76,000 & 11,000 & 170,000 & 11,000 & 170,000 \\
\hline CRYPTOPHYTA & & & & & & \\
\hline CRYPTOPHYCEAE & & & & & & \\
\hline Chroomonas sp. & 19,000 & 340,000 & 5,800 & 100,000 & 13,000 & 220,000 \\
\hline Cryptomonas I & 3,900 & 330,000 & .- & -- & 5,800 & 490,000 \\
\hline Cryptomonas II & 16,000 & 330,000 & 23,000 & 460,000 & 6,800 & 140,000 \\
\hline EUGLENOPHYTA & & & & & & \\
\hline EUGLENOPHYCEAE & & & & & & \\
\hline Euglena I & 970 & $7,200,000$ & -- & -- & 970 & $7,200,000$ \\
\hline Trachelomonas IV & 1,900 & 520,000 & -. & -- & .- & -- \\
\hline PYRROPHYTA & & & & & & \\
\hline DINOPHYCEAE & & & & & & \\
\hline Ceratium sp. & -- & -- & 970 & 59,000 & 970 & $3,700,000$ \\
\hline
\end{tabular}


Table 22. Phytoplankton densities and biovolumes in three reservoirs in west-central Missouri--Continued

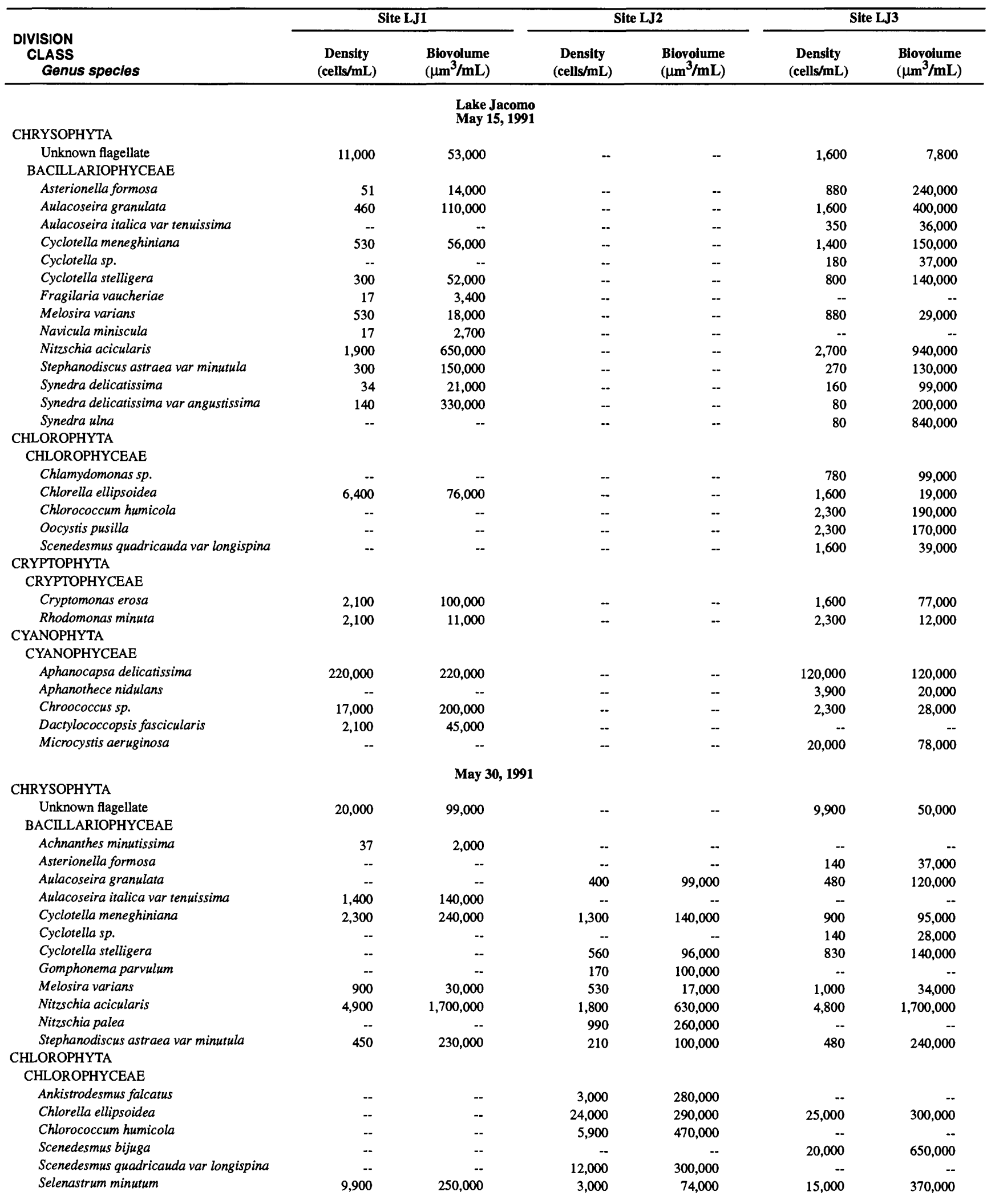


Table 22. Phytoplankton densities and biovolumes in three reservoirs in west-central Missouri-Continued

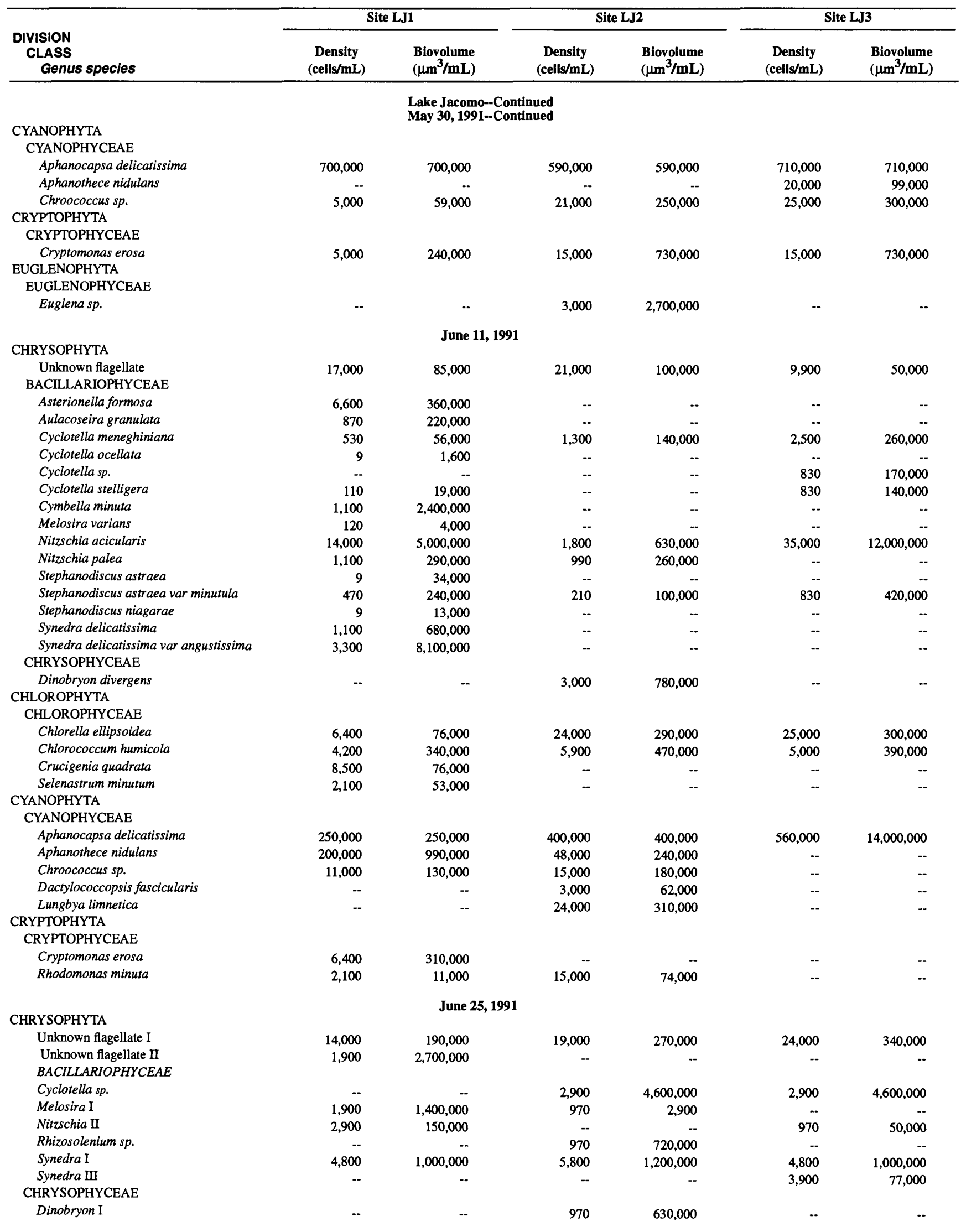


Table 22. Phytoplankton densities and biovolumes in three reservoirs in west-central Missouri-Continued

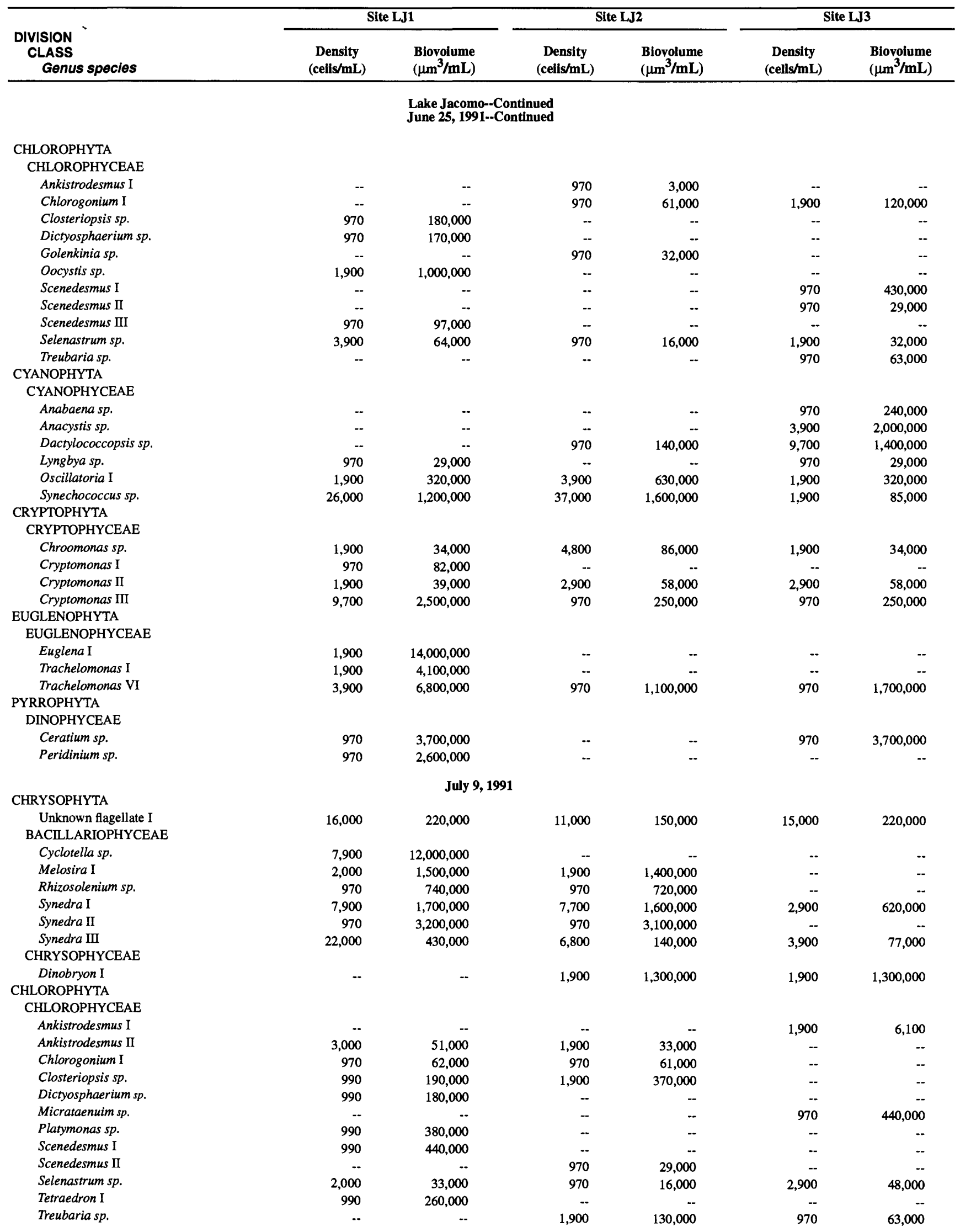


Table 22. Phytoplankton densities and biovolumes in three reservoirs in west-central Missouri-Continued

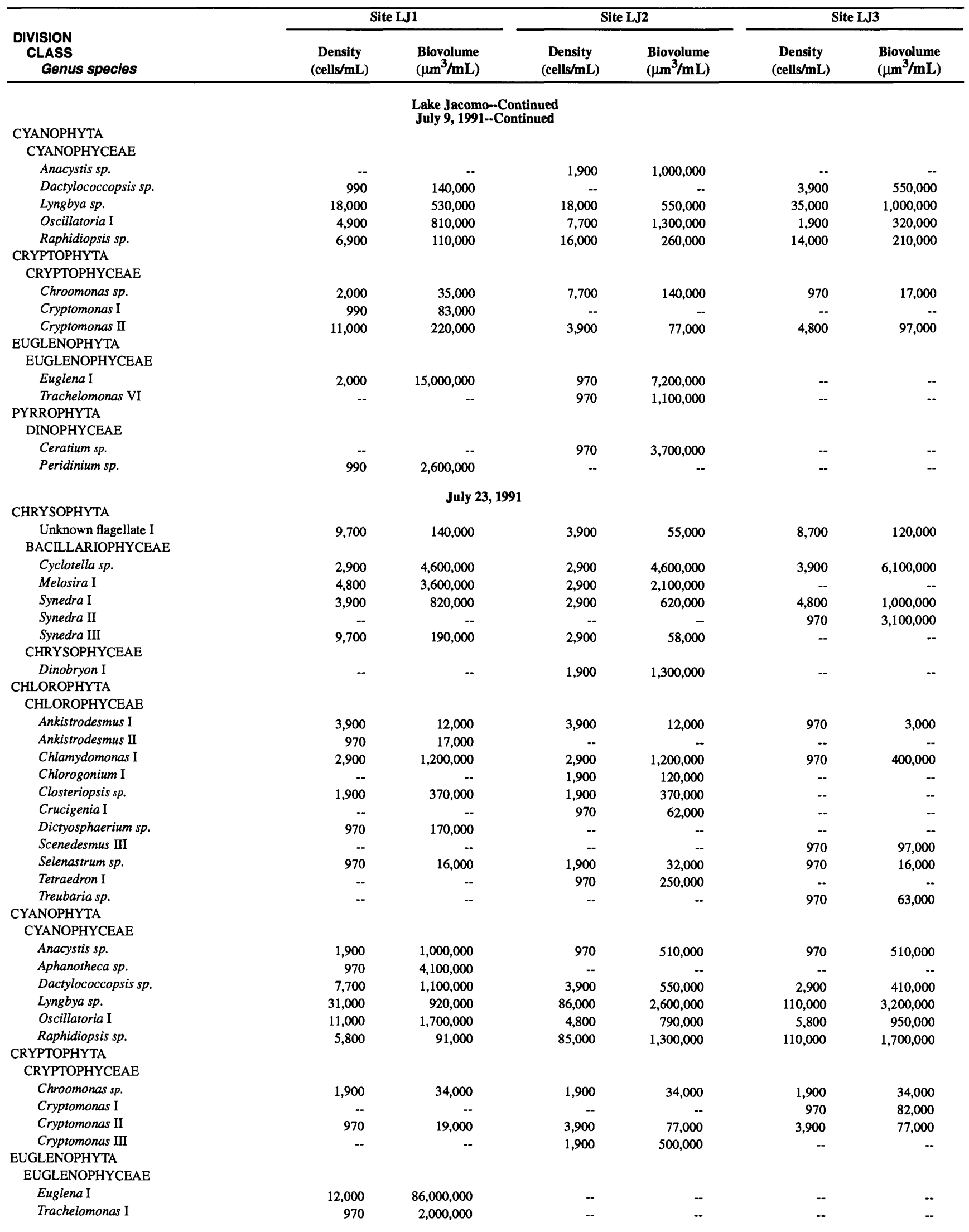


Table 22. Phytoplankton densities and biovolumes in three reservoirs in west-central Missouri-Continued

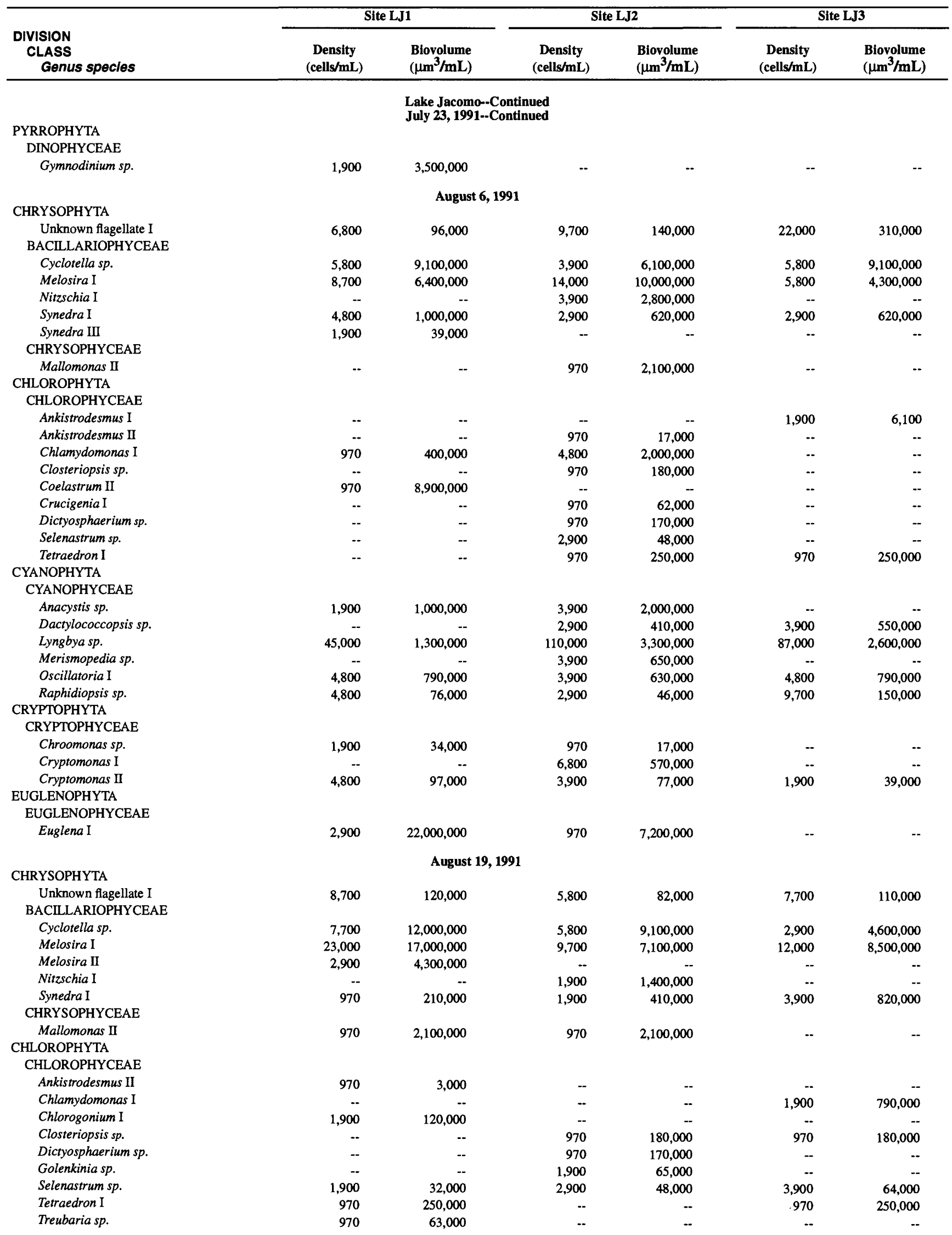


Table 22. Phytoplankton densities and biovolumes in three reservoirs in west-central Missouri-Continued

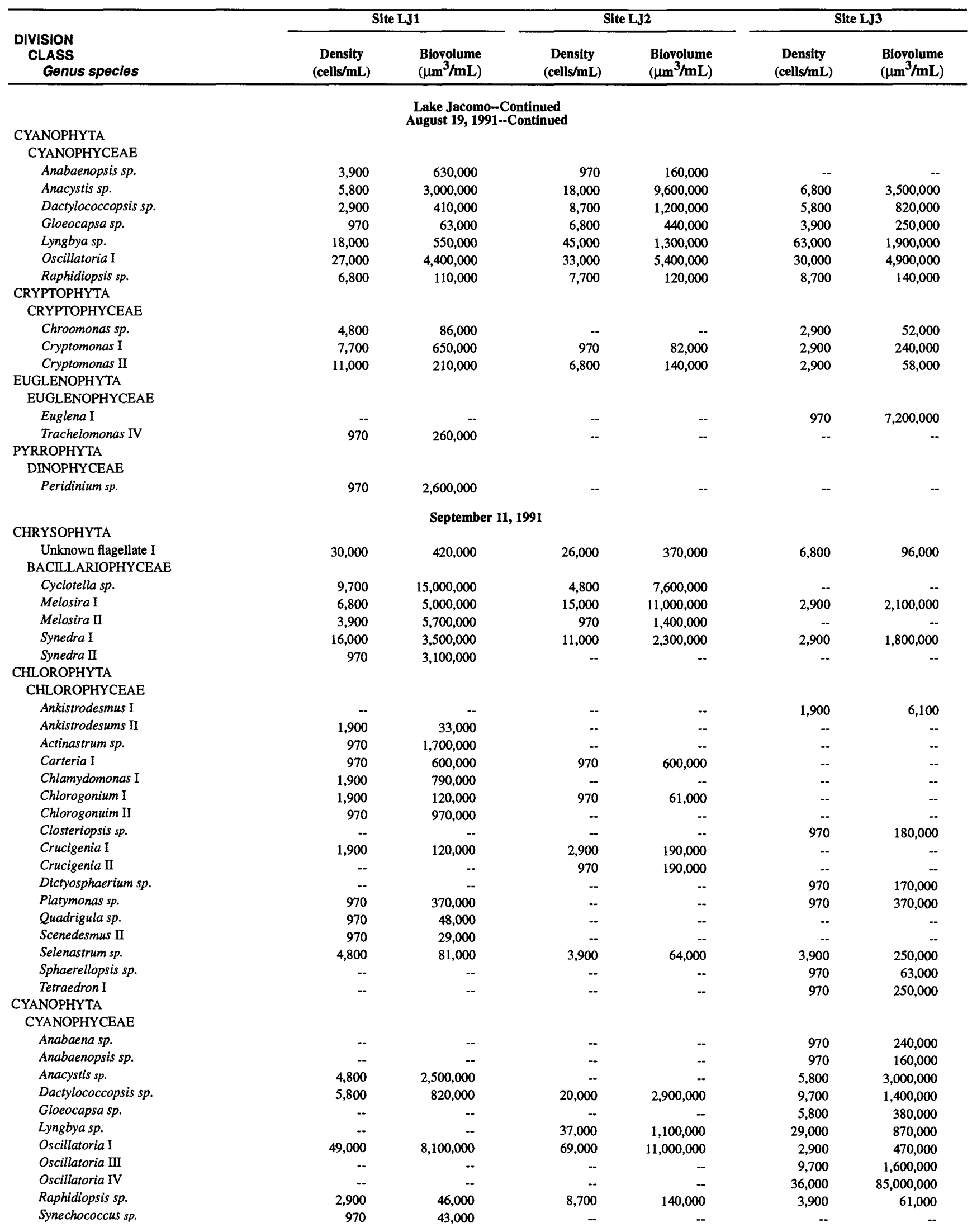


Table 22. Phytoplankton densities and biovolumes in three reservoirs in west-central Missouri-Continued

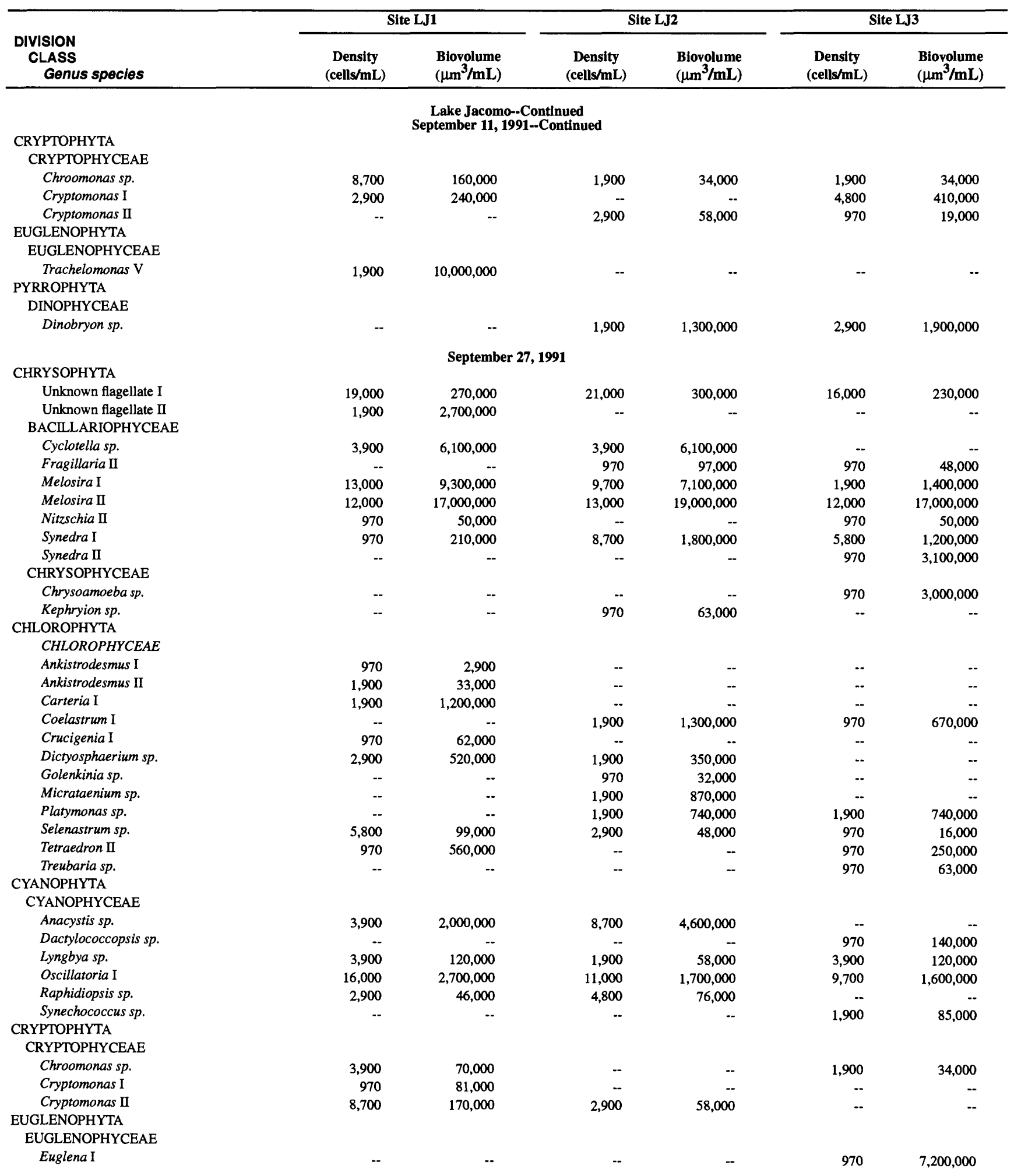


Table 22. Phytoplankton densities and biovolumes in three reservoirs in west-central Missouri-Continued

\begin{tabular}{|c|c|c|c|c|c|c|}
\hline \multirow[b]{2}{*}{$\begin{array}{l}\text { DIVISION } \\
\text { CLASS } \\
\text { Genus species }\end{array}$} & \multicolumn{2}{|c|}{ Site HL1 } & \multicolumn{2}{|c|}{ Site HL2 } & \multicolumn{2}{|c|}{ Site HL3 } \\
\hline & $\begin{array}{l}\text { Density } \\
\text { (cells/mL) }\end{array}$ & $\begin{array}{l}\text { Biovolume } \\
\left(\mu \mathbf{m}^{3} / \mathbf{m L}\right)\end{array}$ & $\begin{array}{l}\text { Density } \\
\text { (cells/mL) }\end{array}$ & $\begin{array}{l}\text { Biovolume } \\
\left(\mu \mathrm{m}^{3} / \mathrm{mL}\right)\end{array}$ & $\begin{array}{c}\text { Density } \\
\text { (cells/mL) }\end{array}$ & $\begin{array}{l}\text { Biovolume } \\
\left(\mu \mathrm{m}^{3} / \mathrm{mL}\right)\end{array}$ \\
\hline \multicolumn{7}{|c|}{$\begin{array}{l}\text { Harrisonville City Lake } \\
\text { April 28, } 1992\end{array}$} \\
\hline \multicolumn{7}{|l|}{ CHRYSOPHYTA } \\
\hline Unknown flagellate I & -- & -- & 2,900 & $4,100,000$ & 53,000 & 750,000 \\
\hline Unknown flagellate II & 23,000 & 330,000 & -- & - & 970 & $1,400,000$ \\
\hline \multicolumn{7}{|l|}{ BACILLARIOPHYCEAE } \\
\hline Cyclotella sp. & 15,000 & $24,000,000$ & 8,700 & $14,000,000$ & 8,700 & $14,000,000$ \\
\hline Eunotia sp. & 970 & 9,700 & .. & .. & -- & .. \\
\hline Melosira I & 970 & 710,000 & -- & -. & - & -. \\
\hline Nitzschia sp. & 970 & 690,000 & -. & - & -- & -- \\
\hline \multicolumn{7}{|l|}{ CHRYSOPHYCEAE } \\
\hline Kephryion sp. & 6,800 & 440,000 & 1,900 & 130,000 & 9,700 & 630,000 \\
\hline Laygnion sp. & - & - & 2,900 & $1,500,000$ & -. & -- \\
\hline Mallomonas I & 11,000 & $4,100,000$ & 21,000 & $8,100,000$ & 20,000 & $7,800,000$ \\
\hline Mallomonas II & 970 & 970,000 & -- & -- & 1,940 & $1,900,000$ \\
\hline Ochromonas sp. & 970 & 110,000 & 970 & 110,000 & 4,800 & 550,000 \\
\hline Quadrigula sp. & -- & -- & - & -. & 1,900 & 97,000 \\
\hline \multicolumn{7}{|l|}{ CHLOROPHYTA } \\
\hline \multicolumn{7}{|l|}{ CHLOROPHYCEAE } \\
\hline Ankistrodesmus I & 8,700 & 27,000 & 6,800 & 21,000 & 6,800 & 21,000 \\
\hline Carteria I & .- & -- & 970 & 600,000 & -- & - \\
\hline Chlamydomonas I & 4,800 & $2,000,000$ & 2,900 & $1,200,000$ & 2,900 & $1,200,000$ \\
\hline Chlamydomonas II & 2,900 & $1,800,000$ & 2,900 & $1,800,000$ & 970 & 590,000 \\
\hline Chlorella sp. & 2,900 & 330,000 & 1,900 & 220,000 & .. & -- \\
\hline Dictyosphaerium sp. & -- & -- & 4,800 & 870,000 & -- & -. \\
\hline Stichococcus sp. & 2,900 & 37,000 & 9,700 & 120,000 & 8,700 & 110,000 \\
\hline Selenastrum sp. & 2,900 & 48,000 & 3,900 & 64,000 & 7,700 & 130,000 \\
\hline \multicolumn{7}{|l|}{ CRYPTOPHYTA } \\
\hline \multicolumn{7}{|l|}{ CRYPTOPHYCEAE } \\
\hline Chroomonas sp. & 28,000 & 500,000 & 41,000 & 720,000 & 46,000 & 810,000 \\
\hline Cryptomonas I & 26,000 & $2,200,000$ & 16,000 & $1,400,000$ & -- & -- \\
\hline Cryptomonas II & -- & -- & 16,000 & 330,000 & 13,000 & 250,000 \\
\hline \multicolumn{7}{|l|}{ EUGLENOPHYTA } \\
\hline EUGLENOPHYCEAE & & & & & & \\
\hline Trachelomonas I & 3,900 & $8,200,000$ & 970 & $2,000,000$ & -. & -. \\
\hline Trachelomonas II & 3,900 & $16,000,000$ & 970 & $4,100,000$ & -. & -- \\
\hline Trachelomonas III & 6,800 & $15,000,000$ & 2,900 & $6,200,000$ & 1,900 & $4,200,000$ \\
\hline & & May & & & & \\
\hline CHRYSOPHYTA & & & & & & \\
\hline Unknown flagellate I & -- & -. & 42,000 & 590,000 & -. & -- \\
\hline BACILLARIOPHYCEAE & & & & & & \\
\hline Cyclotella sp. & -- & -- & 2,900 & $4,600,000$ & -- & -- \\
\hline Synedra I & -. & - & 970 & $3,100,000$ & -. & - \\
\hline CHRYSOPHYCEAE & & & & & & \\
\hline Laygnion sp. & -. &.- & 970 & 510,000 & -- & -- \\
\hline Kephyrion sp. & -- & -. & 2,900 & 190,000 & - & -. \\
\hline Mallomonas I & -- & -. & 970 & 370,000 & -- & -- \\
\hline CHLOROPHYTA & & & & & & \\
\hline CHLOROPHYCEAE & & & & & & \\
\hline Ankistrodesmus I & -- & -. & 2,900 & 8,700 & -- & -. \\
\hline Ankistrodesmus II & -- & -- & 6,800 & 120,000 & -- & .. \\
\hline Arthrodesmus sp. & - & -. & 970 & $1,700,000$ & - & -- \\
\hline Carteria I & - & -- & 970 & 600,000 & -- & -. \\
\hline Chlamydomonas I & -. & -- & 1,900 & 790,000 & - & -- \\
\hline Selenastrum sp. & - & -- & 1,900 & 32,000 & -- & -- \\
\hline Stichococcus sp. & - & - & 9,700 & 120,000 & -- & -- \\
\hline Scenedesmus I & - & -. & 3,900 & $1,700,000$ & -- & $-\cdot$ \\
\hline CRYPTOPHYTA & & & & & & \\
\hline CRYPTOPHYCEAE & & & & & & \\
\hline Chroomonas sp. & - & -. & 46,000 & 830,000 & -- & -. \\
\hline Cryptomonas II & - & -- & 13,000 & 250,000 & -- & -- \\
\hline EUGLENOPHYTA & & & & & & \\
\hline EUGLENOPHYCEAE & & & & & & \\
\hline Trachelomonas I & -- & - & 970 & $2,000,000$ & -- & -- \\
\hline
\end{tabular}


Table 22. Phytoplankton densities and biovolumes in three reservoirs in west-central Missouri--Continued

\begin{tabular}{|c|c|c|c|c|c|c|}
\hline \multirow[b]{2}{*}{$\begin{array}{l}\text { DIVISION } \\
\text { CLASS } \\
\text { Genus species }\end{array}$} & \multicolumn{2}{|c|}{ Site HLI } & \multicolumn{2}{|c|}{ Site HL2 } & \multicolumn{2}{|c|}{ Site HL3 } \\
\hline & $\begin{array}{c}\text { Density } \\
\text { (cells/mL) }\end{array}$ & $\begin{array}{l}\text { Biovolume } \\
\left(\mu \mathbf{m}^{3} / \mathbf{m L}\right)\end{array}$ & $\begin{array}{c}\text { Density } \\
\text { (cells/mL) }\end{array}$ & $\begin{array}{l}\text { Biovolume } \\
\left(\mu \mathbf{m}^{3} / \mathbf{m L}\right)\end{array}$ & $\begin{array}{c}\text { Density } \\
\text { (cells/mL) }\end{array}$ & $\begin{array}{l}\text { Biovolume } \\
\left(\mu \mathrm{m}^{3} / \mathrm{mL}\right)\end{array}$ \\
\hline \multicolumn{7}{|c|}{$\begin{array}{c}\text { Harrisonville City Lake--Continued } \\
\text { May 19, } 1992\end{array}$} \\
\hline \multicolumn{7}{|l|}{ CHRYSOPHYTA } \\
\hline Unknown flagellate I & 95,000 & $1,300,000$ & 445,000 & 630,000 & 64,000 & 900,000 \\
\hline \multicolumn{7}{|l|}{ BACILLARIOPHYCEAE } \\
\hline Cyclotella sp. & 3,900 & $6,100,000$ & -- & -- & - & -- \\
\hline Synedra I & 970 & 210,000 & -- & .. & -. & -- \\
\hline \multicolumn{7}{|l|}{ CHRYSOPHYCEAE } \\
\hline Mallomonas II & 970 & $2,100,000$ & -- & -- & .. & -. \\
\hline \multicolumn{7}{|l|}{ CHLOROPHYTA } \\
\hline \multicolumn{7}{|l|}{ CHLOROPHYCEAE } \\
\hline Ankistrodesmus I & -- & -. & 3,900 & 12,000 & 3,900 & 12,000 \\
\hline Ankistrodesmus II & 3,900 & 67,000 & -- & -- & -. & -- \\
\hline Carteria I & 4,800 & $3,000,000$ & -- & -. & .. & -. \\
\hline Chlamydomonas I & 1,900 & 790,000 & -- & -- & -- & -. \\
\hline Chlorella sp. & 970 & 110,000 & -- & -- & -- & -- \\
\hline Crucigenia I & 970 & 62,000 & 970 & 62,000 & 970 & 62,000 \\
\hline Scenedesmus II & 970 & 2,900 & 3,900 & 120,000 & 5,800 & 170,000 \\
\hline Selenastrum sp. & 9,700 & 160,000 & 4,800 & 81,000 & 5,800 & 97,000 \\
\hline Tetraedron I & 1,900 & 510,000 & 1,900 & 510,000 & -- & -- \\
\hline \multicolumn{7}{|l|}{ CYANOPHYTA } \\
\hline \multicolumn{7}{|l|}{ CYANOPHYCEAE } \\
\hline Anacystis sp. & 40,000 & $21,000,000$ & 6,800 & $3,500,000$ & 18,000 & $9,600,000$ \\
\hline Oscillatoria I & 970 & 160,000 & -- & .. & -- & -. \\
\hline \multicolumn{7}{|l|}{ CRYPTOPHYTA } \\
\hline \multicolumn{7}{|l|}{ CRYPTOPHYCEAE } \\
\hline Chroomonas sp. & 17,000 & 310,000 & 14,000 & 240,000 & 8,700 & 160,000 \\
\hline Cryptomonas I & 3,900 & 330,000 & -. & -- & -- & -- \\
\hline Cryptomonas II & 3,900 & 77,000 & 3,900 & 77,000 & 2,900 & 58,000 \\
\hline \multicolumn{7}{|l|}{ EUGLENOPHYTA } \\
\hline EUGLENOPHYCEAE & & & & & & \\
\hline Euglena I &.- & - & 970 & $7,200,000$ & - & $-\cdot$ \\
\hline Phacus sp. & -. & -- & 970 & 97,000 & -- & -- \\
\hline Trachelomonas I & 970 & $2,000,000$ & - & -- & - & -- \\
\hline & & June & & & & \\
\hline CHRYSOPHYTA & & & & & & \\
\hline Unknown flagellate I & -- & -- & 11,000 & 150,000 & -- & -- \\
\hline BACILLARIOPHYCEAE & & & & & & \\
\hline Cyclotella sp. & -- & -. & 1,900 & $3,000,000$ & -- & -. \\
\hline CHLOROPHYTA & & & & & & \\
\hline CHLOROPHYCEAE & & & & & & \\
\hline Ankistrodesmus I & .- & -- & 970 & 3,000 & -- & -- \\
\hline Selenastrum sp. & -- & -- & 4,800 & 81,000 & -- & -. \\
\hline Tetraedron sp. & -- & -. & 970 & 250,000 & -- & .. \\
\hline CYANOPHYTA & & & & & & \\
\hline CYANOPHYCEAE & & & & & & \\
\hline Anacystis sp. & - & -. & 11,000 & $5,600,000$ & -- & -. \\
\hline Lyngbya sp. & - & -- & 970 & 29,000 & -. & -- \\
\hline CRYPTOPHYTA & & & & & & \\
\hline CRYPTOPHYCEAE & & & & & & \\
\hline Chroomonas sp. & - & -. & 3,900 & 69,000 & -- & -- \\
\hline Cryptomonas II & - & -. & 970 & 19,000 & -. & -- \\
\hline Cryptomonas III & -- & -. & 1,900 & 500,000 & -- & -- \\
\hline & & June 1 & & & & \\
\hline CHRYSOPHYTA & & & & & & \\
\hline Unknown flagellate I & 15,000 & 210,000 & 15,000 & 220,000 & 11,000 & 15,0000 \\
\hline Unknown flagellate II & 970 & $1,400,000$ & 970 & $1,400,000$ & -. & -. \\
\hline BACILLARIOPHYCEAE & & & & & & \\
\hline Cyclotella sp. & -- & $\cdots$ & 2,900 & $4,600,000$ & 2,900 & $4,600,000$ \\
\hline CHRYSOPHYCEAE & & & & & & \\
\hline Kephyrion sp. & -- & -. & .. & .- & 970 & 63,000 \\
\hline
\end{tabular}


Table 22. Phytoplankton densities and biovolumes in three reservoirs in west-central Missouri--Continued

\begin{tabular}{|c|c|c|c|c|c|c|}
\hline \multirow[b]{2}{*}{$\begin{array}{l}\text { DIVISION } \\
\text { CLASS } \\
\text { Genus species } \\
\end{array}$} & \multicolumn{2}{|c|}{ Site HL1 } & \multicolumn{2}{|c|}{ Site HL2 } & \multicolumn{2}{|c|}{ Site HL3 } \\
\hline & $\begin{array}{l}\text { Density } \\
\text { (cells/mL) }\end{array}$ & $\begin{array}{l}\text { Biovolume } \\
\left(\mu \mathrm{m}^{3} / \mathbf{m L}\right)\end{array}$ & $\begin{array}{l}\text { Density } \\
\text { (cells/mL) }\end{array}$ & $\begin{array}{l}\text { Biovolume } \\
\left(\mu \mathrm{m}^{3} / \mathbf{m L}\right)\end{array}$ & $\begin{array}{l}\text { Density } \\
\text { (cells/mL) }\end{array}$ & $\begin{array}{l}\text { Biovolume } \\
\left(\mu \mathbf{m}^{3} / \mathbf{m L}\right)\end{array}$ \\
\hline \multicolumn{7}{|c|}{$\begin{array}{l}\text { Harrisonville City Lake--Continued } \\
\text { June 16, 1992--Continued }\end{array}$} \\
\hline \multirow{2}{*}{\multicolumn{7}{|c|}{$\begin{array}{l}\text { CHLOROPHYTA } \\
\text { CHLOROPHYCEAE }\end{array}$}} \\
\hline & & & & & & \\
\hline Ankistrodesmus I & 970 & 3,000 & 1,900 & 6,000 & .. & .- \\
\hline Ankistrodesmus II & -- & -- & -- & -. & 970 & 17,000 \\
\hline Chlamydomonas I & 970 & 400,000 & -- & -. & -. & -- \\
\hline Crucigenia I & -- & -- & .. & -- & 970 & 62,000 \\
\hline Dictyospaeria sp. & -- & -- & 970 & 170,000 & - & -- \\
\hline Golenkinia sp. & -- & $\ldots$ & 970 & 32,000 & - & -- \\
\hline Scenedesmus I & -- & -- & 970 & 430,000 & -- & -- \\
\hline Scenedesmus II & -. & -- & -- & -- & 1,900 & 58,000 \\
\hline Selenastrum sp. & 2,900 & 48,000 & 1,900 & 32,000 & 3,900 & 64,000 \\
\hline \multicolumn{7}{|l|}{ XANTHOPHYCEA } \\
\hline $\begin{array}{l}\text { Botryococcus sp. } \\
\text { CYANOPHYTA }\end{array}$ & -- & -- & 970 & $1,700,000$ & - & -- \\
\hline \multicolumn{7}{|l|}{ CYANOPHYTA } \\
\hline Anacystis sp. & \multicolumn{6}{|c|}{ CYANOPHYCEAE } \\
\hline Synechococcus sp. & $\begin{array}{r}27,000 \\
4,800\end{array}$ & $\begin{array}{r}14,000,000 \\
210,000\end{array}$ & $\begin{array}{l}9,700 \\
2,900\end{array}$ & $\begin{array}{r}5,100,000 \\
130,000\end{array}$ & $\begin{array}{l}3,900 \\
2,900\end{array}$ & $\begin{array}{r}2,000,000 \\
130,000\end{array}$ \\
\hline \multicolumn{7}{|l|}{ CRYPTOPHYTA } \\
\hline \multicolumn{7}{|l|}{ CRYPTOPHYCEAE } \\
\hline Chroomonas sp. & 13,000 & 220,000 & 14,000 & 240,000 & 11,000 & 190,000 \\
\hline Cryptomonas II & 2,900 & 58,000 & - & -. & .- & -- \\
\hline \multicolumn{7}{|l|}{ EUGLENOPHYTA } \\
\hline \multicolumn{7}{|l|}{ EUGLENOPHYCEAE } \\
\hline Euglena I & 970 & $7,200,000$ & -- & -- & -- & -- \\
\hline \multicolumn{7}{|l|}{ PYRROPHYTA } \\
\hline DINOPHYCEAE & & & & & & \\
\hline Gymnodinium sp. & 970 & $1,700,000$ & -- & -- & -- & -- \\
\hline & & July & & & & \\
\hline CHRYSOPHYTA & & & & & & \\
\hline Unknown flagellate II & -- & -- & 14,000 & $19,000,000$ & -. & -. \\
\hline BACILLARIOPHYCEAE & & & & & & \\
\hline Cyclotella sp. & -- & -- & 5,800 & $9,100,000$ & -- & -- \\
\hline Melosira I & & & 970 & 710,000 & & \\
\hline Nitzschia sp. & -- & -- & 3,900 & 200,000 & -- & -- \\
\hline Synedra I & -- & -- & 1,900 & 410,000 & -- & -. \\
\hline CHLOROPHYTA & & & & & & \\
\hline CHLOROPHYCEAE & & & & & & \\
\hline Ankistrodesmus I & -. & -. & 6,800 & 21,000 & -- & -- \\
\hline Chlorogonium I & -- & -- & 970 & 61,000 & - & -- \\
\hline Closteriopsis sp. & -- & -- & 970 & 180,000 & - & -- \\
\hline Crucigenia I & -- & -- & 1,900 & 120,000 & .. & -. \\
\hline Micratanium sp. & -- & -. & 3,900 & $1,700,000$ & -- & -- \\
\hline Scenedesmus I & .. & -. & 1,900 & 58,000 & -- & -- \\
\hline Selenastrum sp. & -- & -- & 2,900 & 48,000 & - & -- \\
\hline Tetraedron I & -- & -- & 970 & 250,000 & -- & -- \\
\hline CYANOPHYTA & & & & & & \\
\hline CYANOPHYCEAE & & & & & & \\
\hline Anacystis sp. & -- & -. & 6,800 & $3,500,000$ & -- & -. \\
\hline Dactylococcopsis sp. & - & -- & 970 & 140,000 & -. & -. \\
\hline Oscillatoria III & -. & -- & 970 & 160,000 & -- & -- \\
\hline Oscillatoria IV & -- & -- & 970 & $2,300,000$ & -. & -. \\
\hline CRYPTOPHYTA & & & & & & \\
\hline CRYPTOPHYCEAE & & & & & & \\
\hline Chroomonas sp. & -- & -- & 20,000 & 360,000 & -- & -- \\
\hline Cryptomonas I & -- & -- & 2,900 & 240,000 & -- & -. \\
\hline Cryptomonas II & -. & $\ldots$ & 1,900 & 39,000 & -. & - \\
\hline EUGLENOPHYTA & & & & & & \\
\hline EUGLENOPHYCEAE & & & & & & \\
\hline Trachelomonas I & -- & -- & 970 & $2,000,000$ & -- & -- \\
\hline Trachelomonas IV & -- & -- & 970 & 260,000 & -- & -- \\
\hline Trachelomonas VII & - & -- & 970 & 510,000 & -- & -. \\
\hline
\end{tabular}


Table 22. Phytoplankton densities and biovolumes in three reservoirs in west-central Missouri-Continued

\begin{tabular}{|c|c|c|c|c|c|c|}
\hline \multirow[b]{2}{*}{$\begin{array}{l}\text { DIVISION } \\
\text { CLASS } \\
\text { Genus species } \\
\end{array}$} & \multicolumn{2}{|c|}{ Site HLI } & \multicolumn{2}{|c|}{ Site HL2 } & \multicolumn{2}{|c|}{ Site HL3 } \\
\hline & $\begin{array}{c}\text { Density } \\
\text { (cells/mL) }\end{array}$ & $\begin{array}{l}\text { Biovolume } \\
\left(\mu \mathbf{m}^{3} / \mathbf{m L}\right)\end{array}$ & $\begin{array}{c}\text { Density } \\
\text { (cells/mL) }\end{array}$ & $\begin{array}{l}\text { Biovolume } \\
\left(\mu \mathrm{m}^{3} / \mathrm{mL}\right)\end{array}$ & $\begin{array}{c}\text { Density } \\
\text { (cells/mL) }\end{array}$ & $\begin{array}{l}\text { Biovolume } \\
\left(\mu \mathrm{m}^{3} / \mathrm{mL}\right)\end{array}$ \\
\hline \multicolumn{7}{|c|}{$\begin{array}{l}\text { Harrisonville City Lake--Continued } \\
\text { July 28, } 1992\end{array}$} \\
\hline \multicolumn{7}{|l|}{ CHRYSOPHYTA } \\
\hline Unknown flagellate I & -- & -- & 20,000 & 290,000 & 30,000 & 420,000 \\
\hline Unknown flagellate II & 19,000 & $27,000,000$ & -- & -- & -- & - \\
\hline \multicolumn{7}{|l|}{ BACILLARIOPHYCEAE } \\
\hline Cyclotella sp. & 3,900 & $6,100,000$ & 6,800 & $11,000,000$ & 11,000 & $17,000,000$ \\
\hline Melosira I & 970 & 710,000 & 3,900 & $2,800,000$ & 970 & 710,000 \\
\hline Melosira II & -- & -- & 970 & $1,400,000$ & 970 & $1,400,000$ \\
\hline Nitzschia I & -- &.- & 970 & 690,000 & -- & -- \\
\hline Rhizosolenium I & -- & -. & 970 & 720,000 & 1,900 & $1,400,000$ \\
\hline Synedra I & 12,000 & $2,500,000$ & 15,000 & $3,100,000$ & 21,000 & $4,500,000$ \\
\hline \multicolumn{7}{|l|}{ CHRYSOPHYCEAE } \\
\hline Mallomonas II & 970 & 970,000 & -- & -. & -- & -. \\
\hline \multicolumn{7}{|l|}{ CHLOROPHYTA } \\
\hline \multicolumn{7}{|l|}{ CHLOROPHYCEAE } \\
\hline Ankistrodesmus I & 2,900 & 9,100 & 970 & 3,000 & 2,900 & 9,100 \\
\hline Ankistrodesmus II & - & - & 1,900 & 33,000 & 970 & 17,000 \\
\hline Actinastrum sp. & -- & -. & - & -. & 1,900 & $3,400,000$ \\
\hline Carteria I & 2,900 & $1,800,000$ & 970 & 600,000 & -. & .. \\
\hline Characium sp. & 1,000 & 50,000 & -- & -. & -- & -- \\
\hline Chlamydomonas I & -- & -. & 1,900 & 790,000 & 1,900 & 790,000 \\
\hline Chlorella sp. & -- & -. & 970 & 110,000 & - & -- \\
\hline Chlorogonium II & -- & -. & - & -. & 970 & 970,000 \\
\hline Closteriopsis sp. & -- & -- & -- & -. & 2,900 & 550,000 \\
\hline Cosmarium sp. & 970 & 93,000 & 970 & 93,000 & -- & -- \\
\hline Crucigenium II & -- & .. & -- & -- & 4,800 & 970,000 \\
\hline Dictyosphaerium sp. & 970 & 170,000 & 970 & 170,000 & 970 & 170,000 \\
\hline Euastrum sp. & 1,900 & 460,000 & -- & -. & .. & -- \\
\hline Golenkinia sp. & -- & -- & 970 & 32,000 & -- & -- \\
\hline Scenedesmus I & -- & -. & 1,900 & 860,000 & 4,800 & $2,200,000$ \\
\hline Scenedesmus II & 1,900 & 58,000 & - & -- & - & -- \\
\hline Selenastrum sp. & 3,900 & 640,00 & 2,900 & 48,000 & 2,900 & 48,000 \\
\hline Tetraedron I & 1,900 & 510,000 & 1,900 & 510,000 & 970 & 250,000 \\
\hline Oocystis sp. & .. & -- & -- & -- & 1,900 & $1,000,000$ \\
\hline \multicolumn{7}{|l|}{ CYANOPHYTA } \\
\hline \multicolumn{7}{|l|}{ CYANOPHYCEAE } \\
\hline Anabaena sp. & -. & -. & -- & -. & 970 & 240,000 \\
\hline Anacystis sp. & 2,900 & $1,500,000$ & 5,800 & $3,000,000$ & 7,700 & $4,100,000$ \\
\hline Aphanizomenon sp. & 2,900 & 380,000 & - & - & - & -. \\
\hline Dactylococcopsis $s p$ & -- & -- & 1,900 & 270,000 & - & -- \\
\hline Gomphosphaeria sp. & -- & -- & 970 & 160,000 & -- & -- \\
\hline Merismopedia sp. & 1,900 & 330,000 & 970 & 160,000 & 4,800 & 820,000 \\
\hline Oscillatoria I & .. & -- & 2,900 & 470,000 & 970 & 160,000 \\
\hline Oscillatoria IV & -- & -- & 970 & $2,300,000$ & - & -- \\
\hline Raphidiopsis sp. & -- & -- & 970 & 15,000 & -- & - \\
\hline Synechococcus sp. & - & .. & 970 & 43,000 & -- & -- \\
\hline \multicolumn{7}{|l|}{ CRYPTOPHYTA } \\
\hline \multicolumn{7}{|l|}{ CRYPTOPHYCEAE } \\
\hline Chroomonas sp. & 9,700 & 170,000 & 14,000 & 240,000 & 3,900 & 69,000 \\
\hline Cryptomonas I & 11,000 & 900,000 & 1,900 & 160,000 & -- & .- \\
\hline Cryptomonas II & 1,900 & 39,000 & - & - & 970 & 19,000 \\
\hline EUGLENOPHYTA & & & & & & \\
\hline EUGLENOPHYCEAE & & & & & & \\
\hline Euglena I & -. & .. & 970 & $7,200,000$ & -. & -- \\
\hline Trachelomonas II & -- & -- & - & -. & 1,900 & $8,100,000$ \\
\hline Trachelomonas IV & -- & -- & -- & -- & 970 & 260,000 \\
\hline PYRROPHYTA & & & & & & \\
\hline DINOPHYCEAE & & & & & & \\
\hline Ceratium sp. & 970 & $3,700,000$ & -- & -- & - & -- \\
\hline Gymnodinium sp. & 1,900 & $3,500,000$ & - & -- &.- & -. \\
\hline CHRYSOPHYTA & & & & & & \\
\hline Unknown flagellate II & -- & -- & 21,000 & $30,000,000$ & -- & -- \\
\hline
\end{tabular}


Table 22. Phytoplankton densities and biovolumes in three reservoirs in west-central Missouri--Continued

\begin{tabular}{|c|c|c|c|c|c|c|}
\hline \multirow[b]{2}{*}{$\begin{array}{l}\text { DIVISION } \\
\text { CLASS } \\
\text { Genus species }\end{array}$} & \multicolumn{2}{|c|}{ Site HL1 } & \multicolumn{2}{|c|}{ Site HL2 } & \multicolumn{2}{|c|}{ Site HL3 } \\
\hline & $\begin{array}{l}\text { Density } \\
\text { (cells/mL) }\end{array}$ & $\begin{array}{l}\text { Biovolume } \\
\left(\mu \mathrm{m}^{3} / \mathrm{mL}\right)\end{array}$ & $\begin{array}{l}\text { Density } \\
\text { (cells/mL) }\end{array}$ & $\begin{array}{l}\text { Biovolume } \\
\left(\mu \mathrm{m}^{3} / \mathrm{mL}\right)\end{array}$ & $\begin{array}{l}\text { Density } \\
\text { (cells/mL) }\end{array}$ & $\begin{array}{l}\text { Biovolume } \\
\left(\mu \mathrm{m}^{3} / \mathrm{mL}\right)\end{array}$ \\
\hline \multicolumn{7}{|c|}{$\begin{array}{c}\text { Harrisonville City Lake--Continued } \\
\text { August 13, } 1992\end{array}$} \\
\hline \multicolumn{7}{|l|}{ BACILLARIOPHYCEAE } \\
\hline Cyclotella sp. & -- & -- & 4,800 & $7,600,000$ & -- & -- \\
\hline Melosira I & -- & -- & 4,800 & $3,600,000$ & -- & 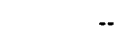 \\
\hline Melosira II & -- & -- & 1,900 & $2,800,000$ & -. & - \\
\hline Nitzschia I & -- & -- & 970 & 690,000 & - & -- \\
\hline Synedra I & -- & -- & 6,800 & $1,400,000$ & -- & -. \\
\hline Synedra II & -- & -- & 1,900 & $3,500,000$ & -- & -- \\
\hline \multicolumn{7}{|l|}{ CHLOROPHYTA } \\
\hline \multicolumn{7}{|l|}{ CHLOROPHYCEAE } \\
\hline Ankistrodesmus I & .. & .. & 970 & 3,000 & -- & .. \\
\hline Ankistrodesmus II & -- & -- & 1,900 & 33,000 & -- & -. \\
\hline Crucigenia II & -- & - & 970 & 190,000 & -- & -- \\
\hline Euastrum sp. & -- & -- & 970 & 230,000 & -. & -- \\
\hline Golenkinia sp. & -- & -- & 970 & 32,000 & -- & -. \\
\hline Scenedesmus II & -. & -- & 970 & 29,000 & -. & -- \\
\hline Selenastrum sp. & -- & -. & 3,900 & 64,000 & - & .. \\
\hline \multicolumn{7}{|l|}{ CYANOPHYTA } \\
\hline \multicolumn{7}{|l|}{ CYANOPHYCEAE } \\
\hline Anacystis sp. & -- & -. & 5,800 & $3,000,000$ & -- & -- \\
\hline Gloeocapsa sp. & - & -. & 970 & 63,000 & - & -- \\
\hline Lyngbya sp. & -- & -- & 1,900 & 58,000 & -- &.- \\
\hline Merismopedia sp. & -- &.- & 9,700 & $1,600,000$ &.- & - \\
\hline Oscillatoria III & -- & -- & 4,800 & 790,000 & -- & -- \\
\hline Oscillatoria IV & -- & -- & 2,900 & $6,900,000$ & -- & -- \\
\hline Raphidiopsis sp. & .. & -- & 970 & 15,000 & -- & .. \\
\hline \multicolumn{7}{|l|}{ CRYPTOPHYTA } \\
\hline \multicolumn{7}{|l|}{ CRYPTOPHYCEAE } \\
\hline Chroomonas sp. & -- & -- & 970 & 17,000 & -- & -. \\
\hline Cryptomonas I & -- & -- & 1,900 & 160,000 & -- & -- \\
\hline \multicolumn{7}{|c|}{ August 27, 1992} \\
\hline \multicolumn{7}{|l|}{ CHRYSOPHYTA } \\
\hline Unknown flagellate I & 6,800 & 96,000 & 6,800 & 96,000 & 4,800 & 68,000 \\
\hline \multicolumn{7}{|l|}{ BACILLARIOPHYCEAE } \\
\hline Cyclotella sp. & 9,700 & $15,000,000$ & 5,800 & $9,100,000$ & 4,800 & 760,0000 \\
\hline Melosira I & 970 & 710,000 & 11,000 & $7,800,000$ & 5,800 & 430,0000 \\
\hline Melosira II & -. & -. & -. & -. & 1,900 & 280,0000 \\
\hline Navicula sp. & 970 & 50,000 & .. & -- & -- & -. \\
\hline Synedra I & 6,800 & $1,400,000$ & 6,800 & $1,400,000$ & 8,700 & $1,800,000$ \\
\hline \multicolumn{7}{|l|}{ CHLOROPHYTA } \\
\hline CHLOROPHYCEAE & & & & & & \\
\hline Ankistrodesmus I & 970 & 3,000 & 1,900 & 6,000 & 970 & 3,000 \\
\hline Ankistrodesmus II & 970 & 17,000 & 2,900 & 50,000 & -- & -. \\
\hline Carteria I & 970 & 600,000 & -- & -- & -- & -- \\
\hline Chlamydomonas I & -- & -- & 970 & 400,000 & 2,900 & $1,200,000$ \\
\hline Chlorogonium I & -- & -. & 4,800 & 300,000 & - & -- \\
\hline Crucigenia I & -- & -- & -. & .. & 970 & 62,000 \\
\hline Dictyosphaerium sp. & -- & .- & 970 & 170,000 & -- & -- \\
\hline Golenkinia sp. & -- & -. & .- & -- & 970 & 32,000 \\
\hline Oocystis sp. & 970 & 510,000 & -- & -- & -- & -- \\
\hline Pediastrum I & -- & -. & 970 & 160,000 & - & -- \\
\hline Platymonas I & 970 & 370,000 & -- & -. & -- & -- \\
\hline Scenedesmus I & -. & -- & -- & -. & 970 & 430,000 \\
\hline Scenedesmus II & -- & -- & 1,900 & 58,000 & - & -- \\
\hline Selenastrum sp. & 970 & 16,000 & 2,900 & 48,000 & 970 & 16,000 \\
\hline Tetraedron I & 970 & 250,000 & -- & -- & 1,900 & 510,000 \\
\hline Tetraedron II & 2,900 & $1,700,000$ & -- & -- & -- & -- \\
\hline Tetraedron III & -. & - & 970 & 250,000 & - & -- \\
\hline
\end{tabular}


Table 22. Phytoplankton densities and biovolumes in three reservoirs in west-central Missouri-Continued

\begin{tabular}{|c|c|c|c|c|c|c|}
\hline \multirow[b]{2}{*}{$\begin{array}{l}\text { DIVISION } \\
\text { CLASS } \\
\text { Genus species }\end{array}$} & \multicolumn{2}{|c|}{ Site HL1 } & \multicolumn{2}{|c|}{ Site HL2 } & \multicolumn{2}{|c|}{ Site HL3 } \\
\hline & $\begin{array}{l}\text { Density } \\
\text { (cells/mL) }\end{array}$ & $\begin{array}{l}\text { Biovolume } \\
\left(\mu \mathrm{m}^{3} / \mathbf{m L}\right)\end{array}$ & $\begin{array}{l}\text { Density } \\
\text { (cells/mL) }\end{array}$ & $\begin{array}{l}\text { Biovolume } \\
\left(\mu \mathrm{m}^{3} / \mathbf{m L}\right)\end{array}$ & $\begin{array}{l}\text { Density } \\
\text { (cells/mL) }\end{array}$ & $\begin{array}{l}\text { Biovolume } \\
\left(\mu \mathrm{m}^{3} / \mathrm{mL}\right)\end{array}$ \\
\hline \multicolumn{7}{|c|}{$\begin{array}{l}\text { Harrisonville City Lake--Continued } \\
\text { August 27, 1992--Continued }\end{array}$} \\
\hline \multicolumn{7}{|l|}{ CYANOPHYTA } \\
\hline \multicolumn{7}{|l|}{ CYANOPHYCEAE } \\
\hline Anabaenopsis sp. & -- & -- & 970 & 160,000 & -- & -- \\
\hline Anacystis sp. & 9,700 & $5,100,000$ & 3,900 & $2,000,000$ & 3,900 & $2,000,000$ \\
\hline Dactylococcopsis sp. & 1,900 & 270,000 & -- & -. & - & -- \\
\hline Gloeocapsa sp. & -- & -- & 1,900 & 130,000 & 970 & 63,000 \\
\hline Lyngbya sp. & 9,700 & 290,000 & 5,800 & 170,000 & 6,800 & 200,000 \\
\hline Merismopedia sp. & -- & -. & 970 & 160,000 & 970 & 160,000 \\
\hline Oscillatoria I & 14,000 & $2,200,000$ & 1,900 & 320,000 & 15,000 & $2,500,000$ \\
\hline Oscillatoria III & -- & -.. & 13,000 & $2,100,000$ & -- & -- \\
\hline Oscillatoria IV & -. & -- & - & - & -- & -. \\
\hline Raphidiopsis sp. & 6,800 & 110,000 & 4,800 & 76,000 & 3,900 & 61,000 \\
\hline Synechococcus sp. & 1,900 & 85,000 & - & -- & 970 & 43,000 \\
\hline \multicolumn{7}{|l|}{ CRYPTOPHYTA } \\
\hline \multicolumn{7}{|l|}{ CRYPTOPHYCEAE } \\
\hline Chroomonas sp. & 3,900 & 69,000 & 3,900 & 69,000 & 970 & 17,000 \\
\hline Cryptomonas I & 8,700 & 730,000 & 970 & 82,000 & 970 & 19,000 \\
\hline Cryptomonas II & .. & -. & 970 & 19,000 & 970 & 82,000 \\
\hline \multicolumn{7}{|l|}{ EUGLENOPHYTA } \\
\hline \multicolumn{7}{|l|}{ EUGLENOPHYCEAE } \\
\hline Euglena I & 970 & $7,200,000$ & 970 & 7,400 & 5,800 & $43,000,000$ \\
\hline Trachelomonas I & -- & -- & 970 & 4,200 & -- & -- \\
\hline \multicolumn{7}{|l|}{ PYRROPHYTA } \\
\hline \multicolumn{7}{|l|}{ DINOPHYCEAE } \\
\hline Gymnodinium sp. & -- & -- & -- & -- & 1,900 & $3,500,000$ \\
\hline & & Septemb & & & & \\
\hline CHRYSOPHYTA & & & & & & \\
\hline Unknown flagellate I & 6,800 & 96,000 & 4,800 & 68,000 & 4,800 & 68,000 \\
\hline BACILLARIOPHYCEAI & & & & & & \\
\hline Cyclotella sp. & 13,000 & $20,000,000$ & 20,000 & $32,000,000$ & 12,000 & $18,000,000$ \\
\hline Melosira I & -. &.- & - & -- & 970 & $1,400,000$ \\
\hline Synedra I & 2,900 & 620,000 & 970 & 210,000 & 2,900 & 620,000 \\
\hline Synedra II & -- & -- & 4,800 & $15,000,000$ & -- & -- \\
\hline CHLOROPHYTA & & & & & & \\
\hline CHLOROPHYCEAE & & & & & & \\
\hline Carteria I & -- & -- & -- & -. & 970 & 600,000 \\
\hline Chlamydomonas I & -- & -- & 970 & 400,000 & - & -- \\
\hline Coelastrum I & - & -. & - & - & 970 & 670,000 \\
\hline Crucigenia I & 1,900 & 120,000 & 970 & 62,000 & 970 & 62,000 \\
\hline Crucigenia II & 2,900 & 580,000 & -- & -. & - & .. \\
\hline Euastrum sp. & -- & -- & 1,900 & 460,000 & -- & -- \\
\hline Golenkinia sp. & -- & -- & -- & -. & 970 & 32,000 \\
\hline Gonium sociale I & 970 & 300,000 & -- & -- & -- & -. \\
\hline Phacotus sp. & - & -- & 970 & 590,000 & -- & -- \\
\hline Quadrigula sp. & 970 & 48,000 & -- & -- & -- & -- \\
\hline Scenedesmus II & 2,900 & 87,000 & 8,700 & 260,000 & 3,900 & 120,000 \\
\hline Selenastrum sp. & 1,900 & 32,000 & 1,900 & 32,000 & 970 & 16,000 \\
\hline Tetraedron I & 1,900 & 510,000 & 2,900 & 760,000 & -- & -- \\
\hline CYANOPHYTA & & & & & & \\
\hline CYANOPHYCEAE & & & & & & \\
\hline Anacystis sp. & 2,900 & $1,500,000$ & 2,900 & $1,500,000$ & 7,700 & $4,100,000$ \\
\hline Dactylococcopsis sp. & - & -- & 970 & 29,000 & 970 & 29,000 \\
\hline Merismopedia sp. & -- & -- & -- & -- & 970 & 160,000 \\
\hline Oscillatoria II & -. & -- & 3,900 & 630,000 & -. & -- \\
\hline Oscillatoria III & -. & -- & -. & -. & 2,900 & 470,000 \\
\hline Raphidiopsis sp. & -- & -. & 970 & 15,000 & 970 & 15,000 \\
\hline Synechococcus I & 1,900 & 85,000 & 970 & 43,000 & 970 & 43,000 \\
\hline CRYPTOPHYTA & & & & & & \\
\hline CRYPTOPHYCEAE & & & & & & \\
\hline Chroomonas sp. & 2,900 & 52,000 & 4,800 & 86,000 & 2,900 & 52,000 \\
\hline Cryptomonas I & 4,800 & 410,000 & 1,900 & 160,000 & - & -- \\
\hline Cryptomonas II & - & -. & - & -- & 2,900 & 58,000 \\
\hline
\end{tabular}


Table 22. Phytoplankton densities and biovolumes in three reservoirs in west-central Missouri--Continued

\begin{tabular}{|c|c|c|c|c|c|c|}
\hline \multirow[b]{2}{*}{$\begin{array}{l}\text { DIVISION } \\
\text { CLASS } \\
\text { Genus species }\end{array}$} & \multicolumn{2}{|c|}{ Site HL1 } & \multicolumn{2}{|c|}{ Site HL2 } & \multicolumn{2}{|c|}{ Site HL3 } \\
\hline & $\begin{array}{l}\text { Density } \\
\text { (cells/mL) }\end{array}$ & $\begin{array}{l}\text { Biovolume } \\
\left(\mu \mathbf{m}^{3} / \mathbf{m L}\right)\end{array}$ & $\begin{array}{c}\text { Density } \\
\text { (cells/mL) }\end{array}$ & $\begin{array}{l}\text { Biovolume } \\
\left(\mu \mathbf{m}^{3} / \mathbf{m} \mathbf{L}\right)\end{array}$ & $\begin{array}{l}\text { Density } \\
\text { (cells/mL) }\end{array}$ & $\begin{array}{l}\text { Biovolume } \\
\left(\mu \mathbf{m}^{3} / \mathbf{m} \mathbf{L}\right)\end{array}$ \\
\hline \multicolumn{7}{|c|}{$\begin{array}{c}\text { Harrisonville City Lake--Continued } \\
\text { October 22, } 1992\end{array}$} \\
\hline \multicolumn{7}{|l|}{ CHRYSOPHYTA } \\
\hline Unknown flagellate I & -- & -- & 4,800 & 68,000 & 2,900 & 41,000 \\
\hline \multicolumn{7}{|l|}{ BACILLARIOPHYCEAE } \\
\hline Cyclotella sp. & 970 & $1,500,000$ & -- & -. & 4,800 & $7,600,000$ \\
\hline Melosira I & -. & -- & 970 & 710,000 & 970 & 710,000 \\
\hline Nitzschia I & 970 & 690,000 & 970 & 690,000 & -. & -- \\
\hline Synedra I & -- & -- & 970 & 210,000 & -- & -- \\
\hline \multicolumn{7}{|l|}{ CHLOROPHYTA } \\
\hline \multicolumn{7}{|l|}{ CHLOROPHYCEAE } \\
\hline Ankistrodesmus I & 3,900 & 12,000 & 970 & 3,000 & 4,800 & 15,000 \\
\hline Ankistrodesmus II & -. & -- & 970 & 17,000 & 970 & 17,000 \\
\hline Carteria I & 970 & 600,000 & 3,900 & $2,400,000$ & 4,800 & $3,000,000$ \\
\hline Chlorella sp. & - & -. & 970 & 13,000 & -- & -- \\
\hline Closteriopsis sp. & 970 & 180,000 & - & - & -- & -- \\
\hline Crucigenia I & 4,800 & 310,000 & 970 & 62,000 & 3,900 & 250,000 \\
\hline Crucigenia II & -- & -. & -- & -. & 970 & 190,000 \\
\hline Dictyosphaerium sp. & -- & -- & 3,900 & 700,000 & -- & -. \\
\hline Platymonas sp. & -- & -. & 970 & 370,000 & -. & -. \\
\hline Scenedesmus II & 5,800 & 170,000 & 3,900 & 120,000 & 5,800 & 170,000 \\
\hline Scenedesmus III & -- & -- & -. & -- & 970 & 250,000 \\
\hline Selenastrum sp. & 4,800 & 81,000 & 3,900 & 64,000 & 3,900 & 64,000 \\
\hline Tetraedron II & -- & -- & -- & -. & 1,900 & $1,100,000$ \\
\hline \multicolumn{7}{|l|}{ CYANOPHYTA } \\
\hline \multicolumn{7}{|l|}{ CYANOPHYCEAE } \\
\hline Anacystis sp. & 5,800 & $3,000,000$ & 6,800 & $3,500,000$ & 4,800 & $2,500,000$ \\
\hline Gloeocapsa sp. & 970 & 63,000 & -- & -- & -- & -. \\
\hline Oscillatoria II & 970 & 160,000 & 970 & 160,000 & -- & -- \\
\hline Synechococcus sp. & 1,900 & 85,000 & 970 & 43,000 & -- & .. \\
\hline \multicolumn{7}{|l|}{ CRYPTOPHYTA } \\
\hline \multicolumn{7}{|l|}{ CRYPTOPHYCEAE } \\
\hline Chroomonas sp. & -- & .. & 970 & 17,000 & 5,800 & 100,000 \\
\hline Cryptomonas I & 1,900 & 160,000 & 6,800 & 570,000 & 4,800 & 410,000 \\
\hline Cryptomonas II & -. & .. & 9,700 & 190,000 & .. & -- \\
\hline \multicolumn{7}{|l|}{ EUGLENOPHYCEAE } \\
\hline Euglena sp. & 2,900 & $22,000,000$ & -. & -- & 4,800 & $37,000,000$ \\
\hline Lepocinclis sp. & - & - & 3,900 & 410,000 & -. & -. \\
\hline \multicolumn{7}{|l|}{ PYRROPHYTA } \\
\hline \multicolumn{7}{|l|}{ DINOPHYCEAE } \\
\hline Gymnodinium II & -- & -. & .- & -- & 1,900 & 62,000 \\
\hline
\end{tabular}


Table 23. Zooplankton densities in Harrisonville City Lake, west-central Missouri [--, not available; organisms per liter]

\begin{tabular}{|c|c|c|c|}
\hline $\begin{array}{c}\text { PHYLUM } \\
\text { CLASS } \\
\text { Order } \\
\text { Genus }\end{array}$ & Site HL1 & Site HL2 & Site HL3 \\
\hline \multicolumn{4}{|c|}{ April 28, 1992} \\
\hline \multicolumn{4}{|l|}{ ARTHROPODA } \\
\hline \multicolumn{4}{|l|}{ CRUSTACEA } \\
\hline \multicolumn{4}{|l|}{ Cladocera } \\
\hline Bosmina & 0.38 & 0.72 & 2.01 \\
\hline Daphnia & 1.74 & .49 & 1.93 \\
\hline Ceriodaphnia & -- & -- & .08 \\
\hline \multicolumn{4}{|l|}{ Copepoda } \\
\hline Diaptomus & 7.92 & 7.07 & 26.9 \\
\hline Thermocyclops & 2.64 & .90 & 3.79 \\
\hline \multicolumn{4}{|l|}{ ROTATORIA } \\
\hline Asplanchna & -- & -- & .81 \\
\hline \multicolumn{4}{|c|}{ May 7, 1992} \\
\hline \multicolumn{4}{|l|}{ ARTHROPODA } \\
\hline \multicolumn{4}{|l|}{ CRUSTACEA } \\
\hline \multicolumn{4}{|l|}{ Cladocera } \\
\hline Bosmina & -- & 1.40 & -- \\
\hline Daphnia & -- & 2.29 & -- \\
\hline \multicolumn{4}{|l|}{ Copepoda } \\
\hline Diaptomus & -- & 10.7 & -- \\
\hline Thermocyclops & -- & 12.7 & -- \\
\hline Macrocyclops & -- & 1.33 & -- \\
\hline \multicolumn{4}{|l|}{ ROTATORIA } \\
\hline Keretella & -- & 1.33 & -- \\
\hline \multicolumn{4}{|c|}{ May 19, 1992} \\
\hline \multicolumn{4}{|l|}{ ARTHROPODA } \\
\hline \multicolumn{4}{|l|}{ CRUSTACEA } \\
\hline \multicolumn{4}{|l|}{ Cladocera } \\
\hline Bosmina & 6.26 & 8.80 & 0.55 \\
\hline Daphnia & 2.64 & 11.6 & 3.82 \\
\hline Ceriodaphnia & .06 & .21 & .14 \\
\hline Diaphanosoma & .12 & .05 & .05 \\
\hline Chydoridae & -- & -- & .05 \\
\hline \multicolumn{4}{|l|}{ Copepoda } \\
\hline Diaptomus & 3.86 & 14.0 & 3.41 \\
\hline Thermocyclops & 1.1 & 3.0 & 1.01 \\
\hline Macrocyclops & .18 & .89 & .37 \\
\hline Cyclops & .06 & -- & -- \\
\hline \multicolumn{4}{|l|}{ ROTATORIA } \\
\hline Asplanchna & 1.41 & 1.2 & 1.2 \\
\hline
\end{tabular}


Table 23. Zooplankton densities in Harrisonville City Lake, west-central Missouri-Continued

\begin{tabular}{|c|c|c|c|}
\hline $\begin{array}{l}\text { PHYLUM } \\
\text { CLASS } \\
\text { Order } \\
\text { Genus }\end{array}$ & Site HLI & Site HL2 & Site HL3 \\
\hline \multicolumn{4}{|c|}{ June 3, 1992} \\
\hline \multicolumn{4}{|l|}{ ARTHROPODA } \\
\hline \multicolumn{4}{|l|}{ CRUSTACEA } \\
\hline \multicolumn{4}{|l|}{ Cladocera } \\
\hline Bosmina & -- & 2.64 & -- \\
\hline Daphnia & -- & 3.32 & -- \\
\hline Ceriodaphnia & -- & .18 & -- \\
\hline Diaphanosoma & -. & .06 & -- \\
\hline \multicolumn{4}{|l|}{ Copepoda } \\
\hline Diaptomus & -- & 7.49 & -- \\
\hline Thermocyclops & -- & .18 & -- \\
\hline Macrocyclops & -- & .55 & - \\
\hline \multicolumn{4}{|l|}{ ROTATORIA } \\
\hline Asplanchna & -- & .92 & -- \\
\hline \multicolumn{4}{|c|}{ June 16, 1992} \\
\hline \multicolumn{4}{|l|}{ ARTHROPODA } \\
\hline \multicolumn{4}{|l|}{ CRUSTACEA } \\
\hline \multicolumn{4}{|l|}{ Cladocera } \\
\hline Bosmina & 5.31 & 0.80 & 10.44 \\
\hline Daphnia & 10.43 & .80 & 8.42 \\
\hline Ceriodaphnia & 2.18 & .46 & 5.69 \\
\hline Diaphanosoma & 1.59 & .26 & 6.21 \\
\hline \multicolumn{4}{|l|}{ Copepoda } \\
\hline Diaptomus & 14.7 & 2.08 & 60.5 \\
\hline Thermocyclops & - & .07 & -- \\
\hline Macrocyclops & 3.42 & .23 & 4.84 \\
\hline \multicolumn{4}{|l|}{ ROTATORIA } \\
\hline Asplanchna & 3.42 & 3.36 & 40.7 \\
\hline \multicolumn{4}{|c|}{ July 9, 1992} \\
\hline \multicolumn{4}{|l|}{ ARTHROPODA } \\
\hline \multicolumn{4}{|l|}{ CRUSTACEA } \\
\hline \multicolumn{4}{|l|}{ Cladocera } \\
\hline Bosmina & - & 0.71 & -- \\
\hline Daphnia & -- & .46 & -- \\
\hline Ceriodaphnia & -- & 1.80 & -- \\
\hline Diaphanosoma & -- & .49 & - \\
\hline \multicolumn{4}{|l|}{ Copepoda } \\
\hline Diaptomus & -- & 3.07 & -- \\
\hline Macrocyclops & -- & .63 & - \\
\hline Cyclops & -- & .25 & - \\
\hline \multicolumn{4}{|l|}{ ROTATORIA } \\
\hline Asplanchna & -- & 1.80 & -- \\
\hline
\end{tabular}


Table 23. Zooplankton densities in Harrisonville City Lake, west-central Missouri-Continued

\begin{tabular}{|c|c|c|c|}
\hline $\begin{array}{c}\text { PHYLUM } \\
\text { CLASS } \\
\text { Order } \\
\text { Genus }\end{array}$ & Site HL1 & Site HL2 & Site HL3 \\
\hline \multicolumn{4}{|c|}{ July 28, 1992} \\
\hline \multicolumn{4}{|l|}{ ARTHROPODA } \\
\hline \multicolumn{4}{|l|}{ CRUSTACEA } \\
\hline \multicolumn{4}{|l|}{ Cladocera } \\
\hline Bosmina & 0.90 & 0.31 & 2.27 \\
\hline Daphnia & 6.15 & 1.08 & 8.98 \\
\hline Ceriodaphnia & 9.65 & 4.45 & 12.36 \\
\hline Diaphanosoma & 3.16 & .45 & 1.66 \\
\hline \multicolumn{4}{|l|}{ Copepoda } \\
\hline Diaptomus & 13.55 & 13.39 & 14.14 \\
\hline Thermocyclops & -- & .34 & .11 \\
\hline Macrocyclops & 4.74 & 4.94 & 6.87 \\
\hline \multicolumn{4}{|l|}{ ROTATORIA } \\
\hline \multirow[t]{2}{*}{ Asplanchna } & 5.76 & 5.04 & 4.16 \\
\hline & \multicolumn{3}{|c|}{ August 13, 1992} \\
\hline \multicolumn{4}{|l|}{ ARTHROPODA } \\
\hline \multicolumn{4}{|l|}{ CRUSTACEA } \\
\hline \multicolumn{4}{|l|}{ Cladocera } \\
\hline Bosmina & -- & 1.19 & -. \\
\hline Daphnia & -- & 1.83 & -- \\
\hline Ceriodaphnia & -- & 6.76 & -- \\
\hline Diaphanosoma & -- & .82 & -- \\
\hline \multicolumn{4}{|l|}{ Copepoda } \\
\hline Diaptomus & -. & 6.47 & -- \\
\hline Thermocyclops & -- & 5.09 & -- \\
\hline Macrocyclops & -- & 2.23 & -- \\
\hline \multicolumn{4}{|l|}{ ROTATORIA } \\
\hline Asplanchna & -- & .95 & -- \\
\hline \multicolumn{4}{|c|}{ August 27, 1992} \\
\hline \multicolumn{4}{|l|}{ ARTHROPODA } \\
\hline \multicolumn{4}{|l|}{ CRUSTACEA } \\
\hline \multicolumn{4}{|l|}{ Cladocera } \\
\hline Bosmina & 3.82 & 1.38 & 2.52 \\
\hline Daphnia & .34 & .40 & 1.98 \\
\hline Ceriodaphnia & 3.34 & 2.08 & 5.66 \\
\hline Diaphanosoma & 7.64 & 1.33 & 3.14 \\
\hline \multicolumn{4}{|l|}{ Copepoda } \\
\hline Diaptomus & 15.62 & 5.34 & 14.72 \\
\hline Thermocyclops & 4.01 & 2.67 & 5.39 \\
\hline Macrocyclops & .68 & 2.97 & 1.77 \\
\hline \multicolumn{4}{|l|}{ ROTATORIA } \\
\hline Asplanchna & 12.04 & 3.00 & 3.92 \\
\hline Keretella & .- & - & .07 \\
\hline
\end{tabular}


Table 23. Zooplankton densities in Harrisonville City Lake, west-central Missouri-Continued

\begin{tabular}{|c|c|c|c|}
\hline $\begin{array}{c}\text { PHYLUM } \\
\text { CLASS } \\
\text { Order } \\
\text { Genus }\end{array}$ & Site HL1 & Site HL2 & Site HL3 \\
\hline \multicolumn{4}{|c|}{ September 18, 1992} \\
\hline \multicolumn{4}{|l|}{ ARTHROPODA } \\
\hline \multicolumn{4}{|l|}{ CRUSTACEA } \\
\hline \multicolumn{4}{|l|}{ Cladocera } \\
\hline Bosmina & 14.34 & 27.68 & 15.55 \\
\hline Daphnia & 7.50 & 24.33 & 10.81 \\
\hline Ceriodaphnia & 7.33 & 13.31 & 9.16 \\
\hline Diaphanosoma & 24.12 & 3.17 & 4.13 \\
\hline \multicolumn{4}{|l|}{ Copepoda } \\
\hline Diaptomus & 8.82 & 14.11 & 8.18 \\
\hline Thermocyclops & 6.75 & 20.66 & 8.38 \\
\hline Macrocyclops & 1.67 & 7.56 & 1.54 \\
\hline \multicolumn{4}{|l|}{ ROTATORIA } \\
\hline \multirow[t]{2}{*}{ Asplanchna } & 3.86 & 6.72 & 9.02 \\
\hline & \multicolumn{2}{|c|}{ October 22, 1992} & \\
\hline \multicolumn{4}{|l|}{ ARTHROPODA } \\
\hline \multicolumn{4}{|l|}{ CRUSTACEA } \\
\hline \multicolumn{4}{|l|}{ Cladocera } \\
\hline Bosmina & 37.46 & 22.06 & 14.27 \\
\hline Daphnia & 8.34 & 28.69 & 40.67 \\
\hline Ceriodaphnia & 3.83 & 3.53 & 3.19 \\
\hline Diaphanosoma & -- & .32 & .13 \\
\hline \multicolumn{4}{|l|}{ Copepoda } \\
\hline Diaptomus & 7.04 & 4.76 & 4.24 \\
\hline Thermocyclops & 4.17 & 4.60 & 8.75 \\
\hline Macrocyclops & 12.45 & 3.25 & 2.36 \\
\hline \multicolumn{4}{|l|}{ ROTATORIA } \\
\hline Asplanchna & 1.16 & 7.02 & 10.11 \\
\hline
\end{tabular}

